\title{
Assessment of the Technical Potential for Achieving Net Zero-Energy Buildings in the Commercial Sector
}

Technical Report NREL/TP-550-41957

December 2007

B. Griffith, N. Long, P. Torcellini, and R. Judkoff National Renewable Energy Laboratory

D. Crawley and J. Ryan

U.S. Department of Energy

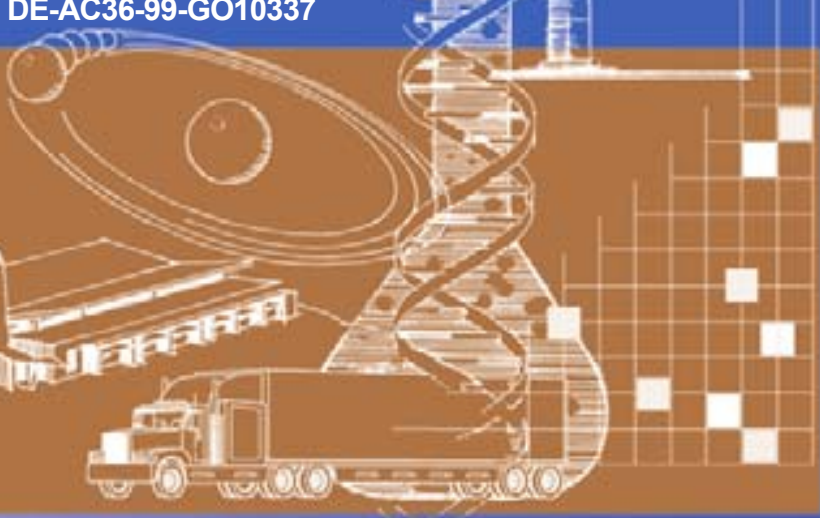




\section{Assessment of the Technical Potential for Achieving Net Zero-Energy Buildings in the Commercial Sector}

Technical Report NREL/TP-550-41957

December 2007

B. Griffith, N. Long, P. Torcellini, and R. Judkoff National Renewable Energy Laboratory

D. Crawley and J. Ryan

U.S. Department of Energy

Prepared under Task No. BEC7.1006

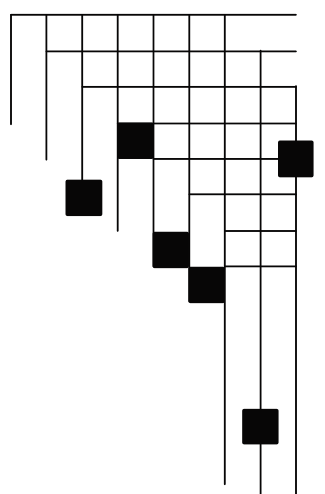




\section{NOTICE}

This report was prepared as an account of work sponsored by an agency of the United States government. Neither the United States government nor any agency thereof, nor any of their employees, makes any warranty, express or implied, or assumes any legal liability or responsibility for the accuracy, completeness, or usefulness of any information, apparatus, product, or process disclosed, or represents that its use would not infringe privately owned rights. Reference herein to any specific commercial product, process, or service by trade name, trademark, manufacturer, or otherwise does not necessarily constitute or imply its endorsement, recommendation, or favoring by the United States government or any agency thereof. The views and opinions of authors expressed herein do not necessarily state or reflect those of the United States government or any agency thereof.

Available electronically at http://www.osti.gov/bridge

Available for a processing fee to U.S. Department of Energy and its contractors, in paper, from:

U.S. Department of Energy

Office of Scientific and Technical Information

P.O. Box 62

Oak Ridge, TN 37831-0062

phone: 865.576 .8401

fax: 865.576 .5728

email: mailto:reports@adonis.osti.gov

Available for sale to the public, in paper, from:

U.S. Department of Commerce

National Technical Information Service

5285 Port Royal Road

Springfield, VA 22161

phone: 800.553.6847

fax: 703.605.6900

email: orders@ntis.fedworld.gov

online ordering: http://www.ntis.gov/ordering.htm 


\section{Contents}

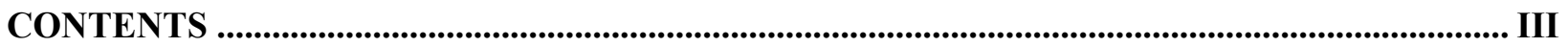

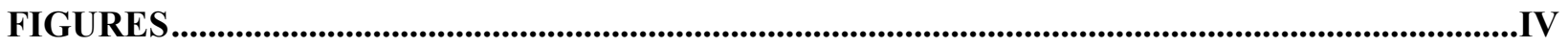

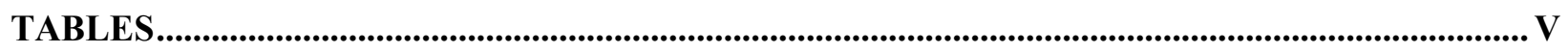

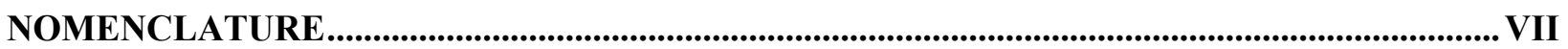

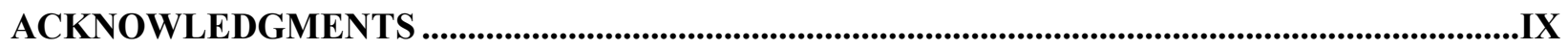

EXECUTIVE SUMMARY: ARE ZERO-ENERGY COMMERCIAL BUILDINGS

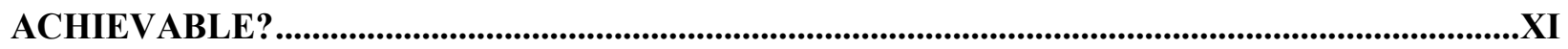

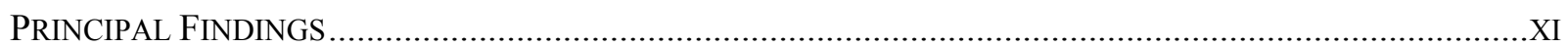

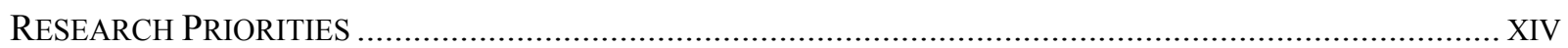

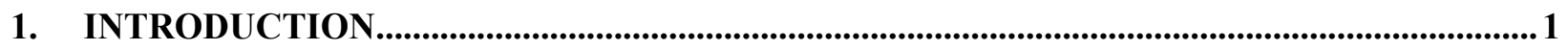

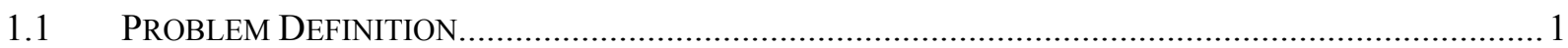

1.2 PROJECT SCOPE

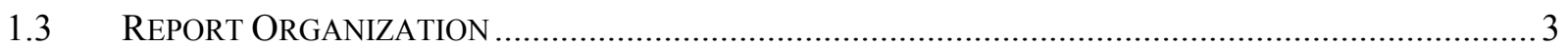

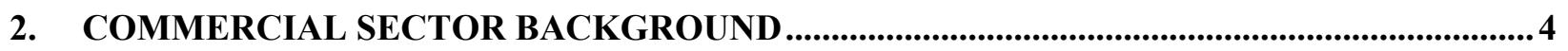

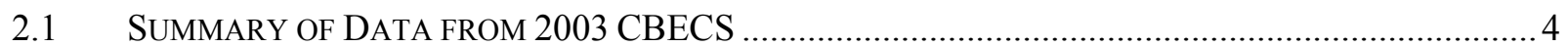

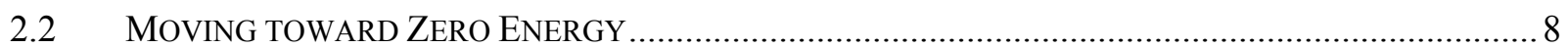

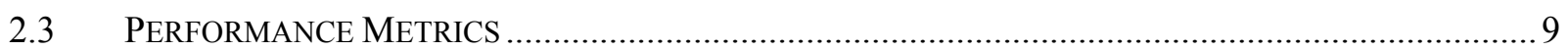

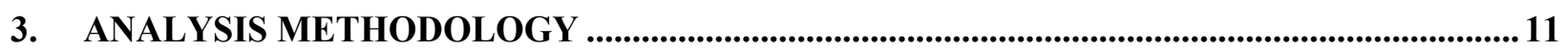

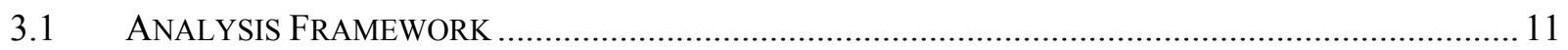

3.2 BASELINE AND MAXIMUM TECHNOLOGY SCENARIOS .......................................................... 12

INVESTIGATING INDIVIDUAL TECHNOLOGIES AND PRACTICES ................................................. 31

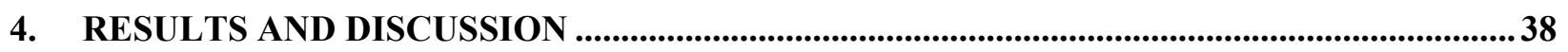

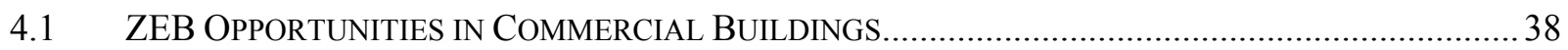

4.2 PROGRAMMATIC FACTORS FOR MEETING THE ZEB GOAL …................................................ 42

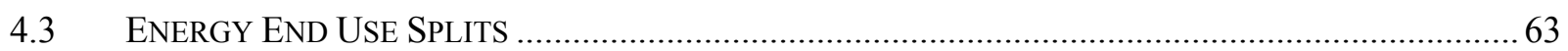

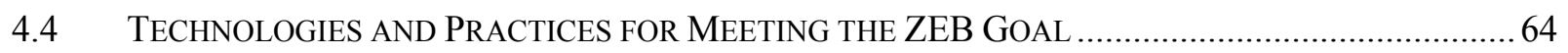

5. RECOMMENDATIONS AND FUTURE RESEARCH.............................................................90

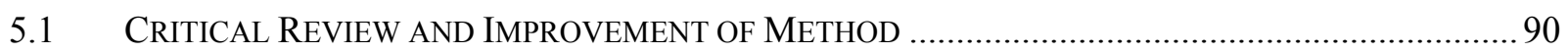

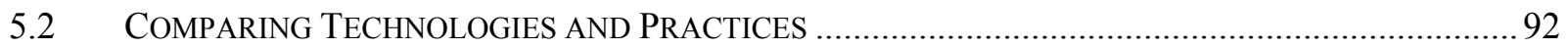

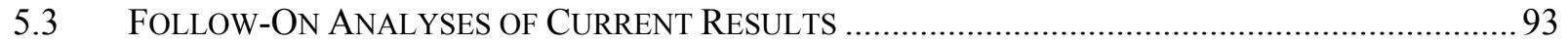

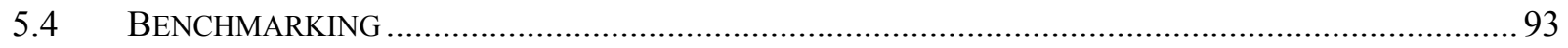

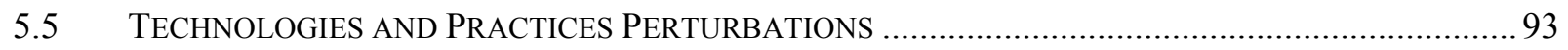

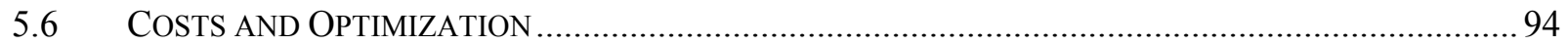

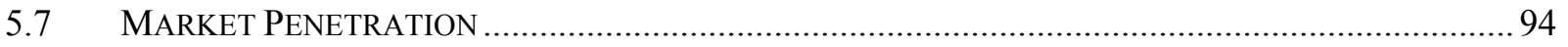

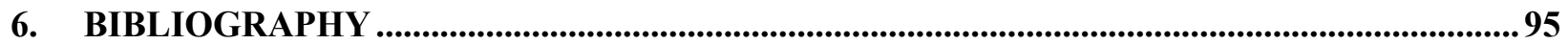




\section{Figures}

Figure ES-1 Average results for EUI for current stock, minimum standard, and Max Tech scenarios ...xii

Figure 1-1

Figure 2-1

Figure 2-2

Figure 2-3

Figure 2-4

Figure 3-1

Figure 3-2

Figure 4-1

Figure 4-2

Figure 4-3

Figure 4-4

Figure 4-5

Figure 4-6

Figure 4-7

Figure 4-8

Figure 4-9

Figure 4-10

Figure 4-11

Figure 4-12

Figure 4-13

Figure 4-15

Figure 4-16

Figure 4-17

Figure 4-18

Figure 4-19

Figure 4-20

Figure 4-21

Figure 4-22

Figure 4-23

Figure 4-24

Figure 4-25

Figure 4-26
Expected growth in commercial sector energy use

Distribution of energy use by commercial subsector for all buildings:

Distribution of number of buildings built since 1990 by subsector: 2003 CBECS data

(EIA 2006).

Distribution of floor area in buildings built since 1990, by subsector: 2003 CBECS

data (EIA 2006)

Distribution of energy use in buildings built since 1990, by subsector: 2003 CBECS

data (EIA 2006).

Overview of analysis and modeling.

Example form changes for Passive Solar scenarios: (a) before and (b) after changes........ 37

Percentage of U.S. commercial buildings sector that can reach the ZEB goal under

various scenarios

Mean site EUIs for entire sector under various scenarios: IP Units $\left(\mathrm{kBtu} / \mathrm{ft}^{2} \cdot \mathrm{yr}\right)$

Mean site EUIs for entire sector for various scenarios: SI Units $\left(\mathrm{MJ} / \mathrm{m}^{2} \cdot \mathrm{yr}\right) \ldots \ldots \ldots \ldots \ldots \ldots \ldots . . . . . . . . . .40$

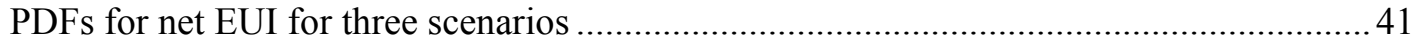

Percentage of floor area that can reach ZEB as a function of non-HVAC\&L EUI: ............ 42

Percentage of floor area that can reach ZEB as a function of number of floors in building: Max Tech scenario .

Percentage of floor area that can reach ZEB for various total floor areas ............................ 43

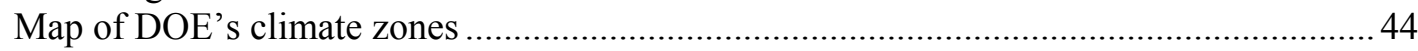

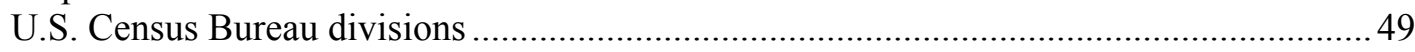

Percentage of floor area that can reach ZEB for various solar production intensities:

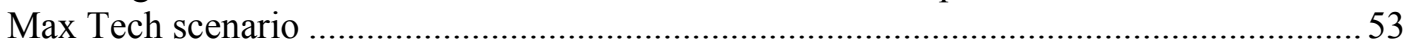

Percentage of floor area that can reach ZEB goal: Max Tech scenario .............................. 54

Net site EUI savings for Max Tech scenario by subsector: IP units ................................55

Aggregated potential net site energy savings from Max Tech technologies and practices.. 56

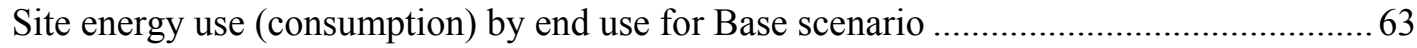

Site energy use (consumption) by end use for Max Tech scenario .......................................64

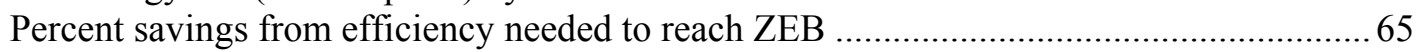

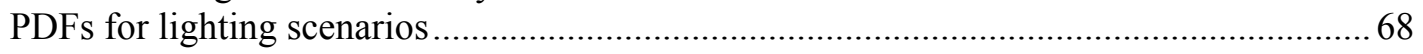

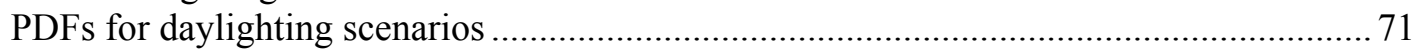

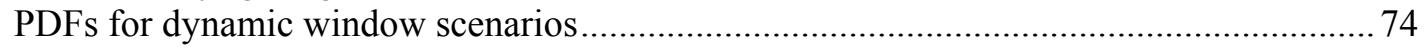

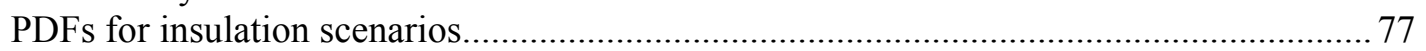

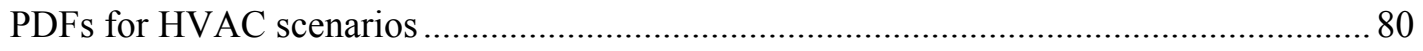

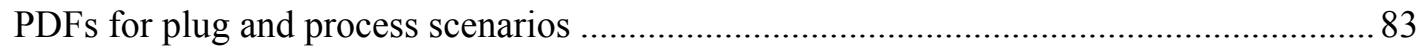

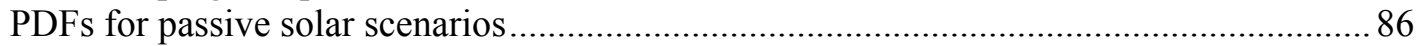

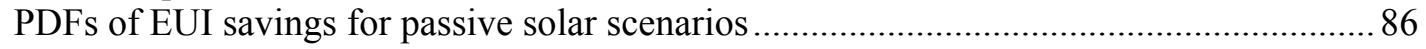

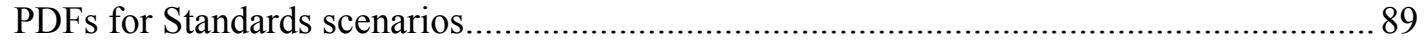




\section{Tables}

Table ES-1 Relative Importance of Subsectors by Energy Performance.............................................xiii

Table 3-1 Opaque Envelope Maximum Assembly U-Factors by Climate Zone: Mass Walls above

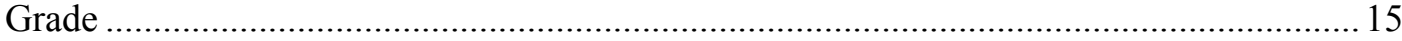

Table 3-2 Opaque Envelope Maximum Assembly U-Factors by Climate Zone: Metal Building

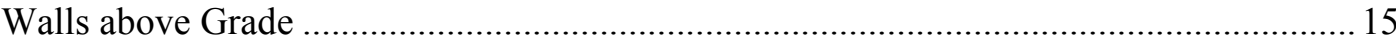

Table 3-3 Opaque Envelope Maximum Assembly U-Factors by Climate Zone: Steel-Framed

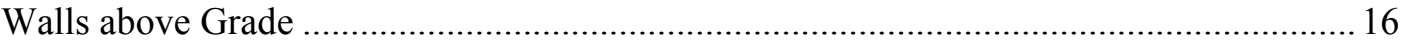

Table 3-4 Opaque Envelope Maximum Assembly U-Factors by Climate Zone: Wood-Framed

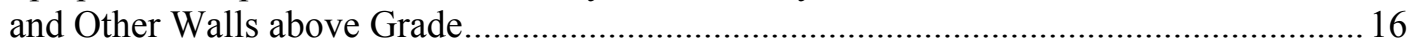

Table 3-5 Opaque Envelope Maximum Assembly U-Factors by Climate Zone: Insulation

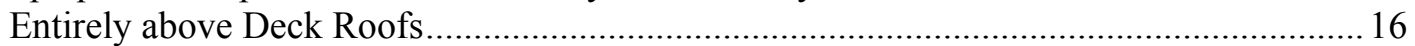

Table 3-6 Opaque Envelope Maximum Assembly U-Factors by Climate Zone: Metal Building

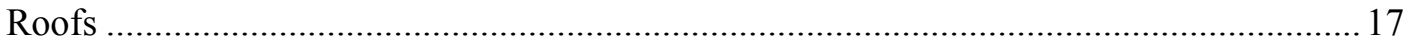

Table 3-7 Opaque Envelope Maximum Assembly U-Factors by Climate Zone: Attics and Other

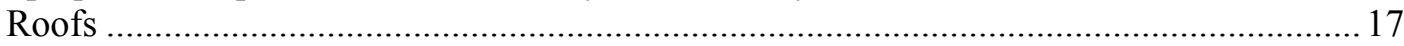

Table 3-8 Fenestration Maximum Assembly U-Factors by Climate Zone: Fixed Vertical Glazing

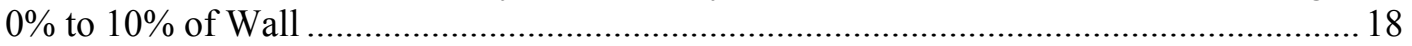

Table 3-9 Fenestration Maximum Assembly U-Factors by Climate Zone: Fixed Vertical Glazing

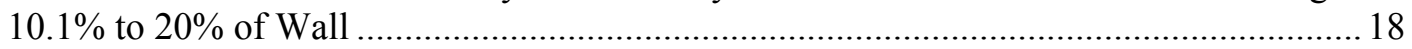

Table 3-10 Fenestration Maximum Assembly U-Factors by Climate Zone: Fixed Vertical Glazing

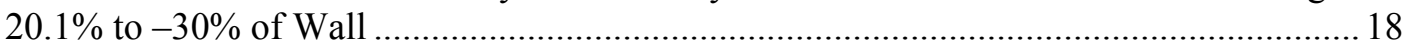

Table 3-11 Fenestration Maximum Assembly U-Factors by Climate Zone: Fixed Vertical Glazing

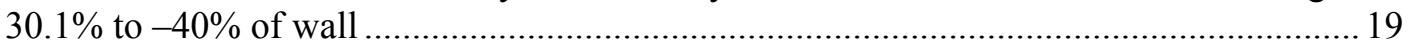

Table 3-12 Fenestration Maximum Assembly U-Factors by Climate Zone: Fixed Vertical Glazing

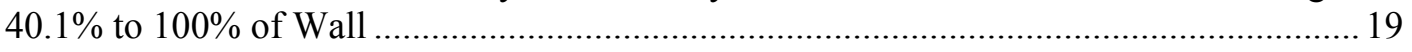

Table 3-13 Fenestration Maximum Assembly SHGC by Climate Zone: Fixed Vertical Glazing 0\%

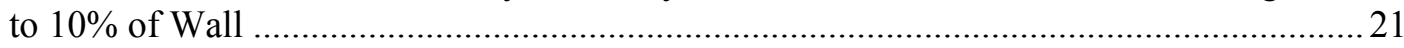

Table 3-14 Fenestration Maximum Assembly SHGC by Climate Zone: Fixed Vertical Glazing

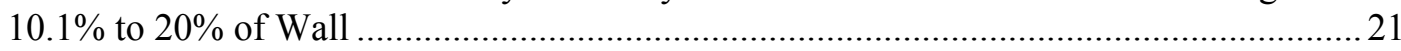

Table 3-15 Fenestration Maximum Assembly SHGC by Climate Zone: Fixed Vertical Glazing

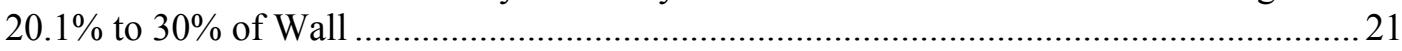

Table 3-16 Fenestration Maximum Assembly SHGC by Climate Zone: Fixed Vertical Glazing $30.1 \%$ to $-40 \%$ of Wall .............................................................................................. 22

Table 3-17 Fenestration Maximum Assembly SHGC by Climate Zone: Fixed Vertical Glazing

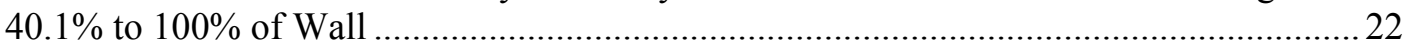

Table 3-18 Dynamic Fenestration Performance Ranges ................................................................ 22

Table 3-19 Infiltration Rates for Opaque Exterior Envelope ......................................................23

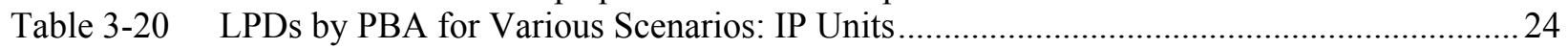

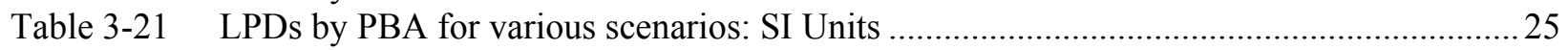

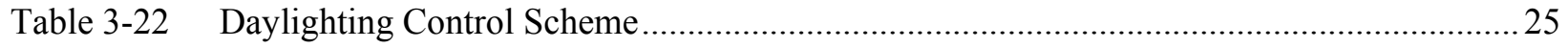

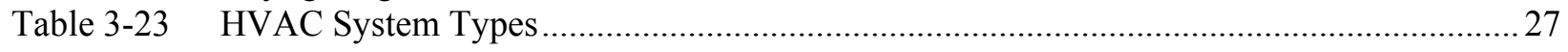

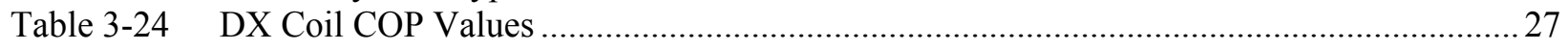

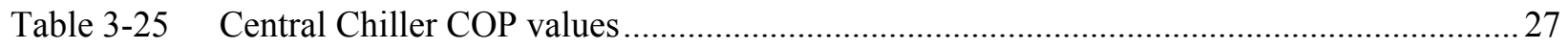

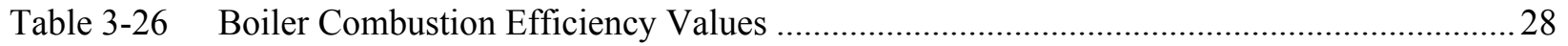

Table 3-27 Natural Gas Heating Coil Combustion Efficiency Values ...............................................28

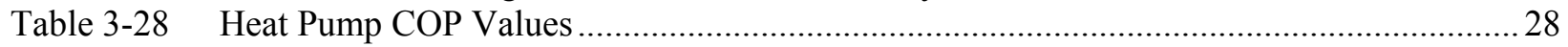

Table 3-29 Packaged System Constant Volume Fan Total Efficiency Values.....................................28

Table 3-30 Packaged System Fan Static Pressure Values ................................................................... 28 
Table 3-31

Table 3-32

Table 3-33

Table 3-34

Table 3-35

Table 3-36

Table 3-37

Table 3-38

Table 3-39

Table 3-40

Table 4-1

Table 4-2

Table 4-3

Table 4-4

Table 4-5

Table 4-6

Table 4-7

Table 4-8

Table 4-9

Table 4-10

Table 4-11

Table 4-12

Table 4-13

Table 4-14

Table 4-15

Table 4-16

Table 4-17

Table 4-18

Table 4-19

Table 4-20

Table 4-21

Table 4-22

Table 4-23

Table 4-24

Table 4-25

Table 4-26

Table 4-27

Table 4-28

Table 4-29

Table 4-30

Table 4-31

Table 5-1
PTAC and PTHP Fan Static Pressure Values.

Central System Variable Volume Fan Total Efficiency Values...........................................29

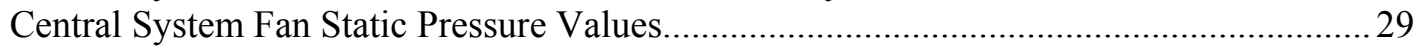

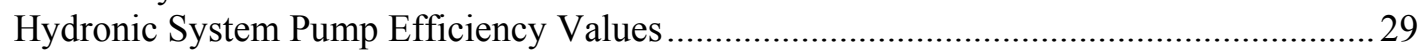

Hydronic System Pump Head Pressure Values.................................................................. 29

Ventilation Energy Recovery Percent Effectiveness Values ............................................29

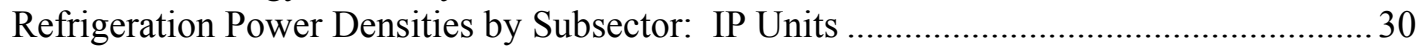

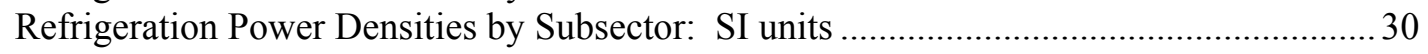

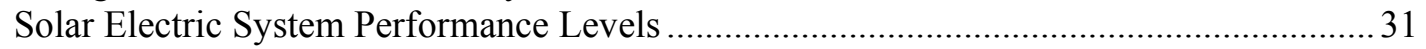

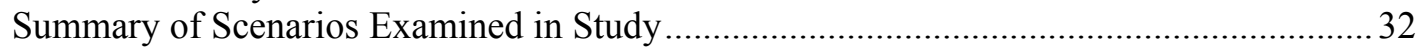

Sector-Wide Average Use Intensity Metrics for Base and Max Tech Scenarios: IP

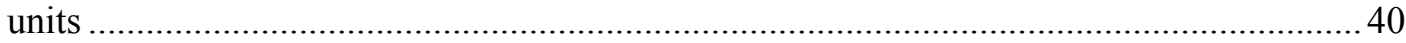

Sector-Wide Average Use Intensity Metrics for Base and Max Tech Scenarios: SI

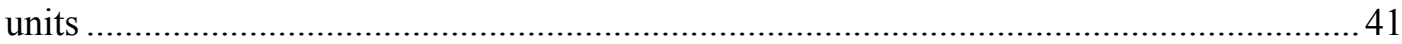

Percentage of Floor Area Able to Reach ZEB by Climate Zone for Various Scenarios...... 46

Net Site EUI for Various Scenarios by Climate Zone: IP Units $\left(\mathrm{kBtu} / \mathrm{ft}^{2} \cdot \mathrm{yr}\right) \ldots \ldots \ldots \ldots \ldots \ldots \ldots . . . . . . . . .47$

Net Site EUI for Various Scenarios by Climate Zone: SI Units $\left(\mathrm{MJ} / \mathrm{m}^{2} \cdot \mathrm{yr}\right) \ldots \ldots \ldots \ldots \ldots \ldots \ldots . . . . . . . . . . . .48$

Percentage of Floor Area Able to Reach ZEB by Census Division....................................50

Net Site EUI for Various Scenarios by Census Division: IP Units $\left(\mathrm{kBtu} / \mathrm{ft}^{2} \cdot \mathrm{yr}\right)$................. 51

Net Site EUI for Various Scenarios by Census Division: SI Units $\left(\mathrm{MJ} / \mathrm{m}^{2} \cdot \mathrm{yr}\right)$..................... 52

Relative Ranking of Subsectors by Energy Performance Opportunities ............................. 57

Base Scenario EUI by Subsectors and Climate Zones IP Units $\left(\mathrm{kBtu} / \mathrm{ft}^{2} \cdot \mathrm{yr}\right)$.......................5

Max Tech Scenario EUI by Subsectors and Climate Zones: IP Units $\left(\mathrm{kBtu} / \mathrm{ft}^{2} \cdot \mathrm{yr}\right)$..............59

Base Scenario EUI by Subsectors and Climate Zones SI Units $\left(\mathrm{MJ} / \mathrm{m}^{2} \cdot \mathrm{yr}\right)$........................... 60

Max Tech Scenario EUI by Subsectors and Climate Zones: SI Units $\left(\mathrm{MJ} / \mathrm{m}^{2} \cdot \mathrm{yr}\right)$................... 61

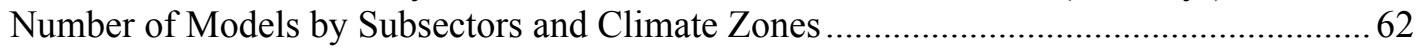

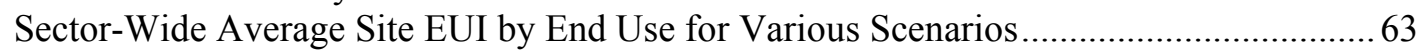

Sector-Wide Average Use Intensity Metrics for Lighting Scenarios: IP units .....................66

Sector-Wide Average Use Intensity Metrics for Lighting Scenarios: SI units ....................67

Sector-Wide Average Use Intensity Metrics for Daylighting Scenarios: IP units ...............69

Sector-Wide Average Use Intensity Metrics for Daylighting Scenarios: SI units ............... 70

Sector-Wide Average Use Intensity Metrics for Dynamic Window Scenarios: IP units .... 72

Sector-Wide Average Use Intensity Metrics for Dynamic Window Scenarios: SI units .... 73

Sector-Wide Average Use Intensity Metrics for Insulation Scenarios: IP units .................. 75

Sector-Wide Average Use Intensity Metrics for Insulation Scenarios: SI units ..................76

Sector-Wide Average Use Intensity Metrics for HVAC Scenarios: IP units .......................78

Sector-Wide Average Use Intensity Metrics for HVAC Scenarios: SI units .......................79

Sector-Wide Average Use Intensity Metrics for Plug and Process Scenarios: IP units ...... 81

Sector-Wide Average Use Intensity Metrics for Plug and Process Scenarios: SI units ...... 82

Sector-Wide Average Use Intensity Metrics for Passive Solar Scenarios: IP units............ 84

Sector-Wide Average Use Intensity Metrics for Passive Solar Scenarios: SI units............ 85

Sector-Wide Average Use Intensity Metrics for Standards Scenarios: IP units ................. 87

Sector-Wide Average Use Intensity Metrics for Standards Scenarios: SI units .................. 88

Comparison of Impact of Individual Technology Areas across the Sector ........................... 92 


\section{NOMENCLATURE}

$\mathrm{AC}$

$\mathrm{ACH}$

AEO

ANSI

ASHRAE

BT

BSR

CBECS

CDD

$\mathrm{CH}_{4}$

CHP

$\mathrm{CO}_{2}$

COP

DC

DOE

EERE

EIA

EPA

EUI

FY

GDP

HDD

HRV

HVAC

IESNA

LBNL

LPD

$\mathrm{NO}_{\mathrm{x}}$

NREL

PBA

PDF

PFP

PSZ-AC alternating current

air changes per hour

Annual Energy Outlook, from EIA

American National Standards Institute

American Society of Heating, Refrigerating and Air-Conditioning Engineers

Building Technologies Program within DOE/EERE

ANSI Board of Standards Review (indicates draft standard prior to ANSI approval)

Commercial Buildings Energy Consumption Survey

cooling degree day

methane

combined heat and power

carbon dioxide

coefficient of performance

direct current

U.S. Department of Energy

Energy Efficiency and Renewable Energy within DOE

Energy Information Administration within DOE

U.S. Environmental Protection Agency

energy use intensity

fiscal year

gross domestic product

heating degree day

heat recovery ventilation (include energy and enthalpy recovery)

heating, ventilating, and air-conditioning

Illuminating Engineering Society of North America

Lawrence Berkeley National Laboratory

lighting power density

oxides of nitrogen

National Renewable Energy Laboratory

principal building activity

probability density function

parallel fan powered (terminal boxes)

packaged single zone air conditioner 
PSZ-HP packaged single zone heat pump

PTAC packaged terminal air conditioner

PTHP packaged terminal heat pump

PVAV packaged variable air volume

PV photovoltaic

R\&D research and development

Sector Energy consumption in the United States is classified by three sectors: transportation, buildings, and industrial.

Subsector Disaggregation of the sector energy use. As defined by the Commercial Buildings

Energy Consumption Survey (CBECS; EIA 2002), there are 20 subsectors, or principle building activities, in commercial buildings. These include retail, office, and food sales buildings, among others. Complete listings are given elsewhere in this report (see, for example, Table 4-9).

TDD tubular daylighting device

TOU Time of Use

VAV variable air volume

ZEB Zero-energy building (or net-zero building). A building with net-zero energy consumption over one year. Assumed to be based on net site energy use. 


\section{ACKNOWLEDGMENTS}

This document was prepared under the auspices of the Building Technologies (BT) Program within the Office of Energy Efficiency and Renewable Energy (EERE) at the U.S. Department of Energy (DOE). The authors would like to thank Stefanie Woodward and René Howard for editing, and Craig Christensen for thoughtful debates on the methodology. Special thanks are extended to the following reviewers for their time, attention and thoughtful contributions to this report: Steve Slayzak, Eric Kozubal, Kurt Roth, Michael Kingsley, Arun Vedhathiri, and Kyle Benne. 


\section{EXECUTIVE SUMMARY: Are Zero-Energy Commercial Buildings Achievable?}

This report summarizes the findings from research conducted at NREL to assess the technical potential for zero-energy building (ZEB) technologies and practices to reduce the impact of commercial buildings on the U.S. energy system. Commercial buildings currently account for $18 \%$ of annual U.S. energy consumption, and energy use is growing along with overall floor area. Reducing the energy use of this sector will require aggressive research goals and rapid implementation of the research results. The U.S Department of Energy (DOE) Building Technologies Program (BT) has adopted a goal of developing market-viable ZEBs by 2025. In this study, NREL researchers developed quantitative predictions to answer the questions: How low can you practically go in terms of energy use? To what extent can rooftop photovoltaics (PV) supply the remaining energy needs of commercial buildings?

NREL used DOE's energy modeling tool EnergyPlus to quantify the energy performance opportunities for a large set of building models derived from the 2003 Commercial Buildings Energy Consumption Survey (CBECS; EIA 2006). Each building was modeled first as a baseline with energy features and performance consistent with new 2005 buildings complying with ANSI/ASHRAE/IESNA 90.1-2004 (cited hereafter as 90.1-2004). Next, we modified these baseline building models with a set of technologies and practices that represent projections for improvements out to 2025 . These annual simulations provide estimates for the energy performance levels that might be achievable in 2025 . These estimates included projections of the number of buildings and floor area that could achieve the ZEB goal.

The analysis is limited to the technical potential and does not assess market penetration or make detailed projections for how the various commercial building subsectors might evolve by 2025 . Technical potential is determined from the energy performance with known technologies and practices projected out to 2025 .

\section{Principal Findings}

The ZEB goal was found to be largely achievable. Based on our projections of future performance levels from currently known technologies and design practices, $62 \%$ of buildings could reach net zero. Calculated according to floor area, rather than by number of buildings, $47 \%$ of commercial building floor area could reach the ZEB goal. If projected future technology and PV systems were applied to all buildings in a way that allows excess electricity production to be freely exported to the grid, new buildings in the commercial sector could, on average, consume only $12.2 \mathrm{kBtu} / \mathrm{ft}^{2} \cdot \mathrm{yr}\left(139 \mathrm{MJ} / \mathrm{m}^{2} \cdot \mathrm{yr}\right)$ or $86 \%$ less than current stock.

Energy efficiency improvements that use the best available technologies and practices and integrated, whole-building design approaches can, on average, reduce consumption by $43 \%$. Reducing consumption through energy efficiency is important in the ZEB context because it requires much less PV to reach netzero. The main reason buildings failed to reach zero in this study was that they had too little roof area to accommodate PV. This study found trends that clearly support the intuitive notion that the buildings with the greatest potential to reduce consumption are more likely to attain the ZEB goal. On average, reductions of 59\% compared to a current standard (ASHRAE 90.1-2004) are needed for PV power systems to provide enough energy to achieve ZEB (offices need $67 \%$ savings, warehouses $6 \%$, educational facilities $43 \%$, and retail $44 \%$ ).

Figure ES-1 shows averaged results for site energy use intensity (EUI) for the buildings included in our modeling. The sector-wide average EUI could be $70.7 \mathrm{kBtu} / \mathrm{ft}^{2} \cdot \mathrm{yr}\left(803 \mathrm{MJ} / \mathrm{m}^{2} \cdot \mathrm{yr}\right)$ if all buildings were rebuilt to current standards. By applying a comprehensive package of technologies and practices, termed "Max Tech" in this report, the EUI could be further reduced to as little as $40.3 \mathrm{kBtu} / \mathrm{ft}^{2} \cdot \mathrm{yr}$ (458 $\mathrm{MJ} / \mathrm{m}^{2} \cdot \mathrm{yr}$ ). The widespread installation of rooftop PV power systems (with all roofs half-covered and unrestricted export of excess electricity) could lead to an average net EUI of just $12.2 \mathrm{kBtu} / \mathrm{ft}^{2} \cdot \mathrm{yr}(139$ $\mathrm{MJ} / \mathrm{m}^{2} \cdot \mathrm{yr}$ ), and many buildings could produce more energy than they consume. "Max Tech" here is just a 
name given to high-performance scenarios in this study and is not intended to imply that better energy performance is not physically possible. Because of the practical limitations imposed by using a generic set of rules to define the scenarios and the challenges of modeling advanced technologies and practices in EnergyPlus, the study is expected to produce relatively conservative results and underestimate the technical potential. For comparison, Figure ES-1 includes measured EUIs for six buildings about which NREL previously published case study reports (Griffith et. al. 2005; Deru et al. 2005a; Deru et al. 2005b; Pless et al. 2005; Torcellini et al. 2005a; Torcellini et al. 2005b). These buildings are not part of this study, but they show that some of the best buildings today can come close to or even exceed the "Max Tech energy-efficient scenario.”

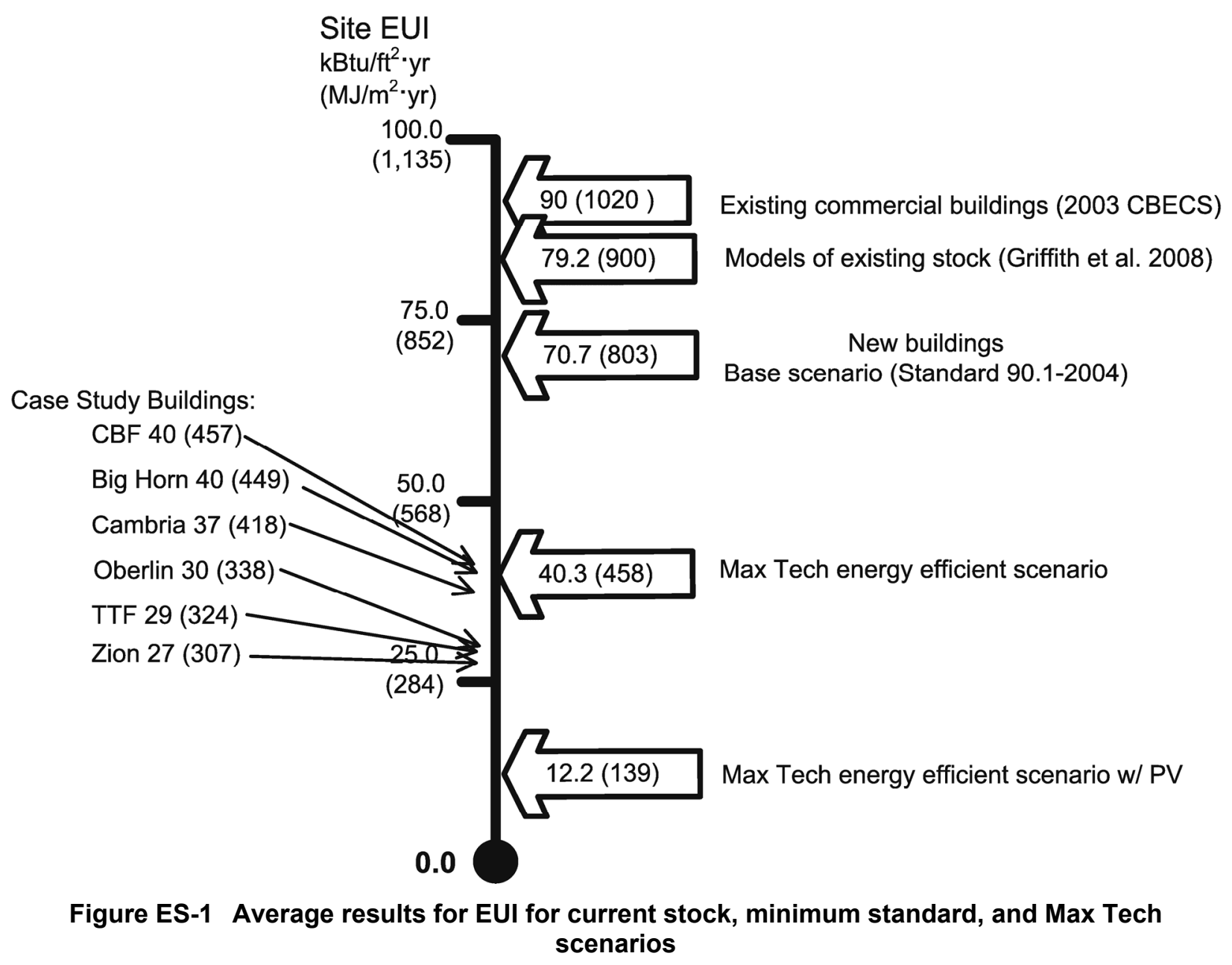

Achieving the ZEB goal on a given building project depends on four characteristics: (1) number of stories; (2) plug and process loads; (3) principal building activity (PBA); and (4) location. Single-story buildings are the most likely to achieve net zero energy consumption. According to 2003 CBECS, $40 \%$ of the nation's commercial buildings are single story; of these, $85 \%$ could reach the ZEB goal by 2025. Buildings with lower plug and process loads (for appliances, office equipment, computers, and other electrical and gas equipment) are also better able to achieve zero. Subsector analysis characterized the differences among PBAs, which are summarized by ordinal rankings in Table ES-1. Subsectors with the best chance of achieving zero energy consumption are nonrefrigerated warehouses, vacant, religious worship, retail, and education. The subsectors that are least likely to meet the goal are hospitals, food service establishments, and laboratories. Office buildings have a below-average chance of achieving zero, largely because of plug and process loads and height. 
Table ES-1 Relative Importance of Subsectors by Energy Performance

\begin{tabular}{|l|c|c|c|}
\hline \multicolumn{1}{|c|}{$\begin{array}{c}\text { Subsector } \\
\text { (PBA) }\end{array}$} & $\begin{array}{c}\text { Rank by } \\
\text { Aggregate } \\
\text { Energy Savings }\end{array}$ & $\begin{array}{c}\text { Rank by } \\
\text { Fraction that } \\
\text { Can Meet ZEB }\end{array}$ & $\begin{array}{c}\text { Rank by EUI } \\
\text { Savings }\end{array}$ \\
\hline \hline Office/professional & 3 & 10 & 16 \\
\hline Nonrefrigerated warehouse & 1 & 1 & 8 \\
\hline Education & 2 & 5 & 11 \\
\hline Retail (excluding mall) & 5 & 4 & 4 \\
\hline Public assembly & 6 & 8 & 9 \\
\hline Service & 4 & 6 & 3 \\
\hline Religious worship & 7 & 3 & 12 \\
\hline Lodging & 8 & 12 & 18 \\
\hline Food service & 9 & 17 & 2 \\
\hline Health care (inpatient) & 11 & 16 & 15 \\
\hline Public order and safety & 15 & 11 & 14 \\
\hline Food sales & 14 & 14 & 1 \\
\hline Health care (outpatient) & 12 & 9 & 7 \\
\hline Vacant & 10 & 2 & 13 \\
\hline Other & 14 & 7 & 10 \\
\hline Skilled nursing & 13 & 15 & 6 \\
\hline Laboratory & 16 & 18 & 17 \\
\hline Refrigerated warehouse & 17 & 12 & 5 \\
\hline
\end{tabular}

The study revealed that overall building size is not a good indicator of ability to reach zero. (Figure 4-7 plots the trends in the effect of overall floor area observed in the simulation results.) There are many large single-story buildings, so this effect is weaker.

In conducting the assessment, NREL modeled a number of alternate scenarios to better understand how individual technologies and practices can support attaining the ZEB goal. The technology areas investigated include: efficiency versus supply, lighting, daylighting, dynamic windows, thermal insulation, HVAC, plug and process loads, passive solar architecture, and standards. In the context of current practice, the potential to reduce whole-building site EUI is highest for HVAC, followed by lighting, dynamic windows, insulation, plug and process loads, daylighting, and passive solar, in order. In the ZEB context, the order of importance shifts: the highest potential to reduce whole-building net site EUI is thermal insulation, followed by lighting, plug and process loads, HVAC, dynamic windows, daylighting, and passive solar, in order. If we examine the potential to reduce net source EUI rather than site EUI, the highest potential is for plug and process loads, followed by lighting, thermal insulation, HVAC, dynamic windows, passive solar, and daylighting. Alternatively, if we examine the potential to reduce peak electrical power demand, the highest potential is for thermal insulation, followed by lighting, HVAC, dynamic windows, plug and process loads, daylighting, and passive solar. The modeling results show that industry-developed Standards have experienced moderate improvements; 90.1-1999 (ASHRAE 1999) is 5\% less stringent than 90.1-2004 (ASHRAE 2004a), but significant improvements with prescriptive standards are possible, as evidenced by a $27 \%$ improvement found for the measures in proposed BSR/ASHRAE/USGBC/IESNA Standard 189P (ASHRAE 2007).

The method used in the study leads to conservative results for the technical potential for daylighting. Savings from daylighting are probably under-predicted because we purposely accepted the overall geometrical composition of the existing commercial building stock (as estimated from 2003 CBECS data). Except in one scenario, we did not change building geometries to better accommodate daylighting strategies. The method also does not account for differences in the technical risk associated with actually achieving forecasted levels of performance. For example, advanced lighting technology carries some 
technical risk that the high luminous efficacies needed for a 50\% reduction in LPD cannot be achieved, but good daylighting design, once the geometric implications are accepted, poses essentially no risk.

\section{Research Priorities}

The ZEB goal is more widely achievable than might be casually assumed, which makes the goal useful for guiding research priorities in the commercial sector. NREL's assessment of the opportunities for ZEB resulted in several priority research recommendations:

- Establish a formal and clear definition of a ZEB. This study used net site energy of zero or less (less in this context means that the building produces more energy than it consumes) within the building envelope. We favor this definition because it is verifiable and does not require complicated conversion factors to be developed and maintained or energy systems to be included outside of buildings. However, there are pros and cons for all the possible definitions of ZEBs, including net zero source energy, net zero energy costs, and net zero carbon emissions.

- Establish a strategy for selecting subsectors on which to focus based on two priority criteria: (1) how easily the ZEB goal can be met and (2) how much sector energy can be reduced. The warehousing subsector offers the best opportunity in both criteria because warehouses are often single-story buildings with low plug and process loads. Educational and office buildings represent a good opportunity to reduce overall energy use. The service and retail subsectors are the next biggest opportunity.

- Develop a targeting strategy for selecting technology areas on which to focus based on different priority criteria: (1) how significant the savings potential is for current practice and (2) how significant the savings potential is for ZEBs. For ZEB commercial buildings, current research programs for lighting and dynamic windows should be augmented with efforts to improve thermal insulation levels, increase the efficiency of appliances and HVAC components, and promote publication and adoption of aggressive energy standards such as

BSR/ASHRAE/USGBC/IESNA Standard 189P. Daylighting technology should not be neglected because it has relatively low technical risk (compared to advanced lighting) and because it can have a powerful positive effect in some building types (daytime operating hours and much of the regularly occupied floor plate within 20 feet of an outside surface) and on productivity and health. Though not modeled directly in this study, attaining performance levels suggested by the modeling results will also depend on success in the areas of integrated design, controls, commissioning and operation.

- Develop and maintain a set of standardized benchmark building definitions and models that offer consistent methods for measuring progress. These buildings should focus on ZEB issues such as the solar resource (rather than just efficiency) and include a relatively small number of models to enable technologies and practices to be studied cost effectively at the national level.

- Improve the accuracy of input data on plug and process loads and schedules. The results show that in future ZEBs, plug and process loads are expected to be the largest energy end use; however, few hard data are available about them. Research is required to collect submetered data that go far beyond those obtained by CBECS. 


\section{INTRODUCTION}

\subsection{Problem Definition}

The Energy Information Agency's (EIA) Annual Energy Outlook 2007 (AEO) (EIA 2007) provides a sobering forecast for growth in the amount of energy that the commercial sector consumes. Figure 1-1 shows the forecasts for-and the recent history of - energy use in this sector along with U.S. gross domestic product (GDP). Energy use in the commercial sector is linked to GDP because new buildings are needed to accommodate economic expansion. AEO 2007 predicts that the intensity of energy use will hold quite steady and that growth will be driven by increases in commercial floor area, which are forecast to grow by $1.5 \%$ or (currently) 1.8 billion $\mathrm{ft}^{2}\left(167\right.$ million $\left.\mathrm{m}^{2}\right)$ per year. Because of this growth, and the fact that buildings remain in use for decades, we need to move quickly and aggressively to reduce the burden this sector places on the national energy system. An aggressive goal of significantly reducing energy use to zero net impact for new commercial buildings is needed to cope with geometric growth in floor area and slow replacement of stock. Successfully meeting this goal will allow economic growth to be decoupled from the sector's energy use and help to mitigate risks to the economy that may arise from future constraints on energy supply.

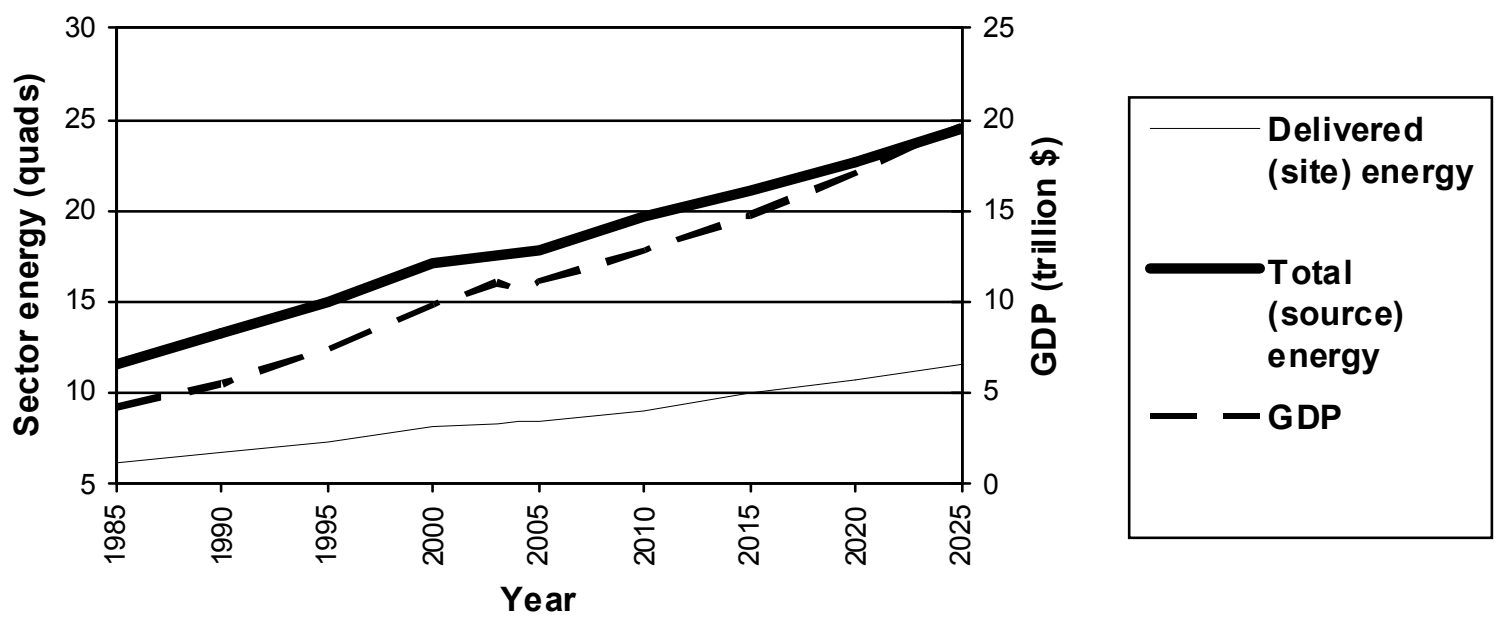

Figure 1-1 Expected growth in commercial sector energy use ${ }^{1}$

Designing a building in such a way that energy efficiency and on-site production convert it from an energy consumer to an energy producer lies at the heart of the zero-energy building (ZEB) concept. This concept is being researched at the National Renewable Energy Laboratory (NREL) through Building Technologies Program (BT)-funded research. NREL selected photovoltaic (PV) power systems as the technology for on-site production because the roofs of virtually all commercial buildings are viable sites. The analysis here is constrained to the footprints of buildings and does not include energy distribution and transmission.

${ }^{1}$ AEO 2007 and historical data sources at www.eia.doe.gov/emeu/aer/txt/stb0201c.xls and www.eia.doe.gov/oiaf/analysispaper/excel/table16.xls. 
One could variously define the exact meaning of meeting the ZEB goal. For this assessment, NREL used the net zero site energy definition. A net site ZEB produces as much energy as it uses over a year when accounted for at the site, and natural gas energy use is offset with on-site generation at a 1:1 ratio. Advantages of this choice for defining net zero energy are that it can be verified and measured at the utility meter, avoids the need to develop and maintain conversion factors, and is always more restrictive than a definition based on net source. This choice has the disadvantage that it amplifies the importance of natural gas relative to electricity (in terms of fuel use at the site). Though not yet resolved, the usual question of site- versus source-based analysis is more complicated in the ZEB context where a net export of electrical energy is needed to offset energy from natural gas. Because others may want to look at other definitions, we also provide summary results for different metrics, including source energy, cost of energy, equivalent-carbon emissions, water used for electricity production, and peak power demand (Torcellini et al. 2006).

\subsection{Project Scope}

\subsubsection{Objectives}

This assessment characterizes commercial building energy performance in the context of the U.S. Department of Energy's (DOE) BT program's long-range vision for ZEBs. The BT program has set a goal of developing market-viable low- and zero-energy buildings, and this assessment was conducted to determine the technical potential of that goal for the commercial buildings sector. We use the term technical potential to refer to "maximum technology" scenarios that are used to estimate what is possible in the sector, and therefore do not include cost and economic analyses such as assessing market penetration or projecting how the sector might evolve. NREL researchers focused on evaluating sets of known technologies and practices and modeling the system interactions with detailed engineering calculations.

For the assessment, NREL used EnergyPlus to produce a data set of energy performance metrics for commercial building prototypes in various subsectors and climates. We used the information gathered from these data sets to:

- Determine what can be achieved with current and emerging technologies in the context of meeting the goal of net-zero energy use.

- Determine the technical potential for energy savings in the sector.

- Identify where additional technology R\&D is needed to meet BT's programmatic goals.

\subsubsection{Methodology and Activities}

NREL used sets of prototypical building models that represent the building stock to determine the energy performance potential. The assessment covered in this report includes building types and climates based on the 2003 Commercial Buildings Energy Consumption Survey (2003 CBECS) (EIA 2006).

Our analysis takes these prototypical building models and determines the maximum potential energy performance based on technologies that are projected to be available in 20 years. We also used input variations to understand the relative importance of various technologies for achieving high performance.

The NREL researchers conducted this research in a series of steps:

1. Conducted an FY 2004 pilot study to determine required data sets and refine methodology.

2. Determined a set of high-level parameters, including site location, total floor area, geometric form, operating schedules, plug and process load levels, lighting levels, ventilation rates, and occupancy, for describing buildings. 
3. Developed and demonstrated analysis methodology with public use data from the 1999 CBECS (EIA 2002) to create a comprehensive set of prototypical models by mapping CBECS data to high-level parameters used to develop EnergyPlus input files (Griffith and Crawley 2006).

4. Refined methodology and input assumptions; developed prototypical models using 2003 CBECS (EIA 2006). Document methodology and compare models of existing stock to 2003 CBECS survey results (Griffith et al. 2008).

5. Developed alternative "what-if" scenarios to explore how various technologies and practices affect technical potential.

6. Used EnergyPlus to produce a set of energy performance results for commercial buildings.

7. Documented findings in this final report.

\subsection{Report Organization}

This report is organized in two tiers that contain increasingly technical content. The first tier is the Executive Summary. The second tier forms the body of the report, and is presented in five sections. Section 1 introduces the problem and methods NREL used in this research; Section 2 summarizes available background information on the commercial sector. Section 3 summarizes the methods we used in this study to evaluate the potential for meeting the ZEB goal in the sector, Section 4 presents and discusses selected results from the study, and Section 5 is a bibliography.

This report is closely related to a second report that presents the methodology for how detailed EnergyPlus engineering models were developed from 2003 CBECS data and compares simulation results to survey results (Griffith et al. 2008). 


\section{COMMERCIAL SECTOR BACKGROUND}

In simple terms, commercial buildings are used for purposes that are not industrial, residential, or agricultural (Reed et al. 2004). This section presents a brief summary of the commercial sector and the vision for moving toward net-zero energy buildings.

\subsection{Summary of Data from 2003 CBECS}

CBECS is a survey of U.S. buildings that the EIA conducts every four years. The 2003 CBECS includes data from a field survey of non-mall commercial buildings with a sample size of 4,820 . Weighting factors indicate how many buildings are represented by each sample to represent the entire U.S. commercial building sector. For each building, 2003 CBECS presents data on floor area, number of floors, census division, basic climatic design criteria, principal building activity (PBA), number of employees, and many other characteristics. CBECS's use for official government statistics has made it far and away the best source of data about the energy performance of the U.S. commercial buildings sector. CBECS is the basis for what researchers know about the commercial sector and is often used as the basis for analyses. This section provides only a brief summary of the survey results so that the reader can become familiar with the overall scale of the commercial sector and the categories used to delineate the various subsectors. Griffith et al. (2008) provide detailed analysis of the 2003 CBECS public use data.

Energy consumption is one indicator of energy use; energy intensity is another. Energy intensity is the amount of energy consumed per unit of service or activity. The most commonly used measure of energy intensity is consumption per building floor area, or energy use intensity (EUI), but consumption per hour of operation or consumption per worker can be useful as well. The area must be carefully defined. For example, conditioned floor area further defines the floor area-it may be specific to the energy source (e.g., floor area served by electricity), or specific to the end use (e.g., heated floor area [Barley et. al. 2005]). In this study we use the CBECS's definition of floor area, which includes unconditioned areas.

Commercial buildings in the United States used 5.8 quadrillion Btu (6.1 EJ) of all major fuels (electricity, natural gas, fuel oil, and district steam or hot water) at their sites in 2003 (EIA 2006). Figure 2-1 shows how total energy consumption can be broken down by PBA and illustrates that most energy is consumed in three groups of subsectors: service/retail, office/professional, and education. Office buildings use the most energy, which reflects the fact that they are the most common commercial building type and have above average EUIs. The range of site EUIs for all the samples varies from 0 to $1,589 \mathrm{kBtu} / \mathrm{ft}^{2} \cdot \mathrm{yr}(0$ to $18,048 \mathrm{MJ} / \mathrm{m}^{2} \cdot \mathrm{yr}$ ) (however, masking of floor area data for anonymity may artificially increase the scatter in EUI). The highest intensity activities take place in laboratories, food service establishments, and inpatient health care facilities; the lowest take place in vacant buildings, houses of religious worship, and nonrefrigerated warehouses. 


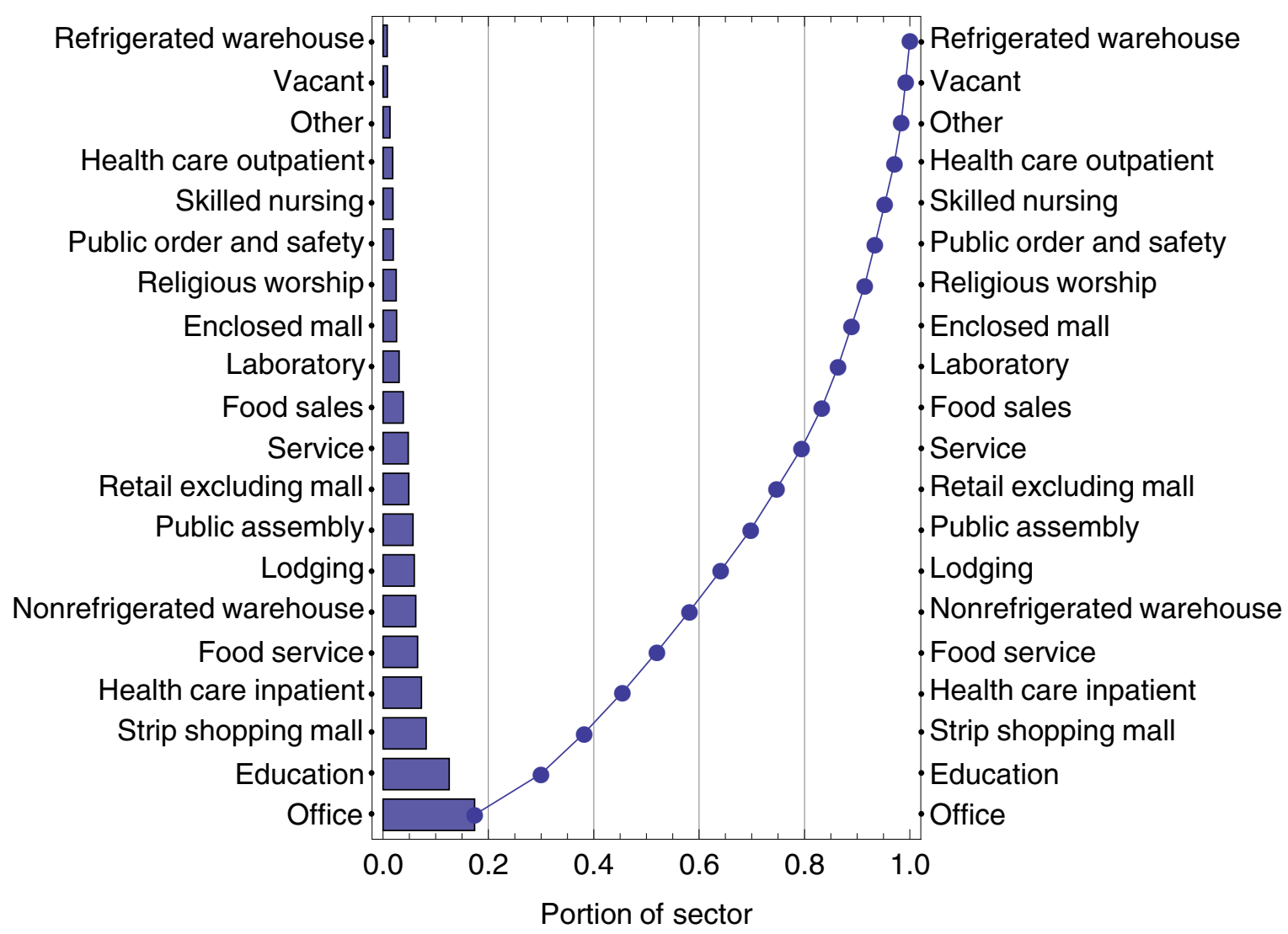

Figure 2-1 Distribution of energy use by commercial subsector for all buildings: 2003 CBECS data (EIA 2006)

Commercial building floor area in 2003 encompassed 71.7 billion $\mathrm{ft}^{2}\left(6.7\right.$ billion $\left.\mathrm{m}^{2}\right)$ in 4.86 million buildings. Seventy-two percent of the buildings were smaller than $10,000 \mathrm{ft}^{2}\left(929 \mathrm{~m}^{2}\right)$. Slightly more than half of buildings were 1,000 to $5,000 \mathrm{ft}^{2}\left(93\right.$ to $\left.465 \mathrm{~m}^{2}\right)$. The $2003 \mathrm{CBECS}$ data also include the number of floors, which is of particular interest to net-zero analyses because for a given total floor area, the roof area available for PV power production is strongly influenced by the number of floors. The 2003 CBECS data show that single-story buildings are the most common, and represent $40 \%$ of the weighted floor area (EIA 2006).

The EIA released public use data for 2003 CBECS in two batches. The first is termed "non-mall" and is the focus of this assessment. The second batch of data included malls, but was not used for the bulk of this study because the data for building characteristics are incomplete (to preserve anonymity). The exclusion of mall-type buildings (both enclosed and strip malls), means this study omits a segment of the commercial sector that constitutes roughly $9.6 \%$ of the floor area and $10.8 \%$ of the energy use.

Because this ZEB analysis focuses on new construction, it is informative to characterize new construction by analyzing CBECS data for only the more recent vintage buildings - those constructed between 1990 and 2003 (2003 CBECS includes 1,404 such samples). Figure 2-2 shows the distribution of new construction across subsectors by number of buildings, and Figure 2-3 shows the distribution by floor 
area. Figure 2-4 shows the distribution of site energy use by subsector. These data show that nonrefrigerated warehouses, offices, educational facilities, service, and retail spaces are the more significant types of buildings built since the 1990s.

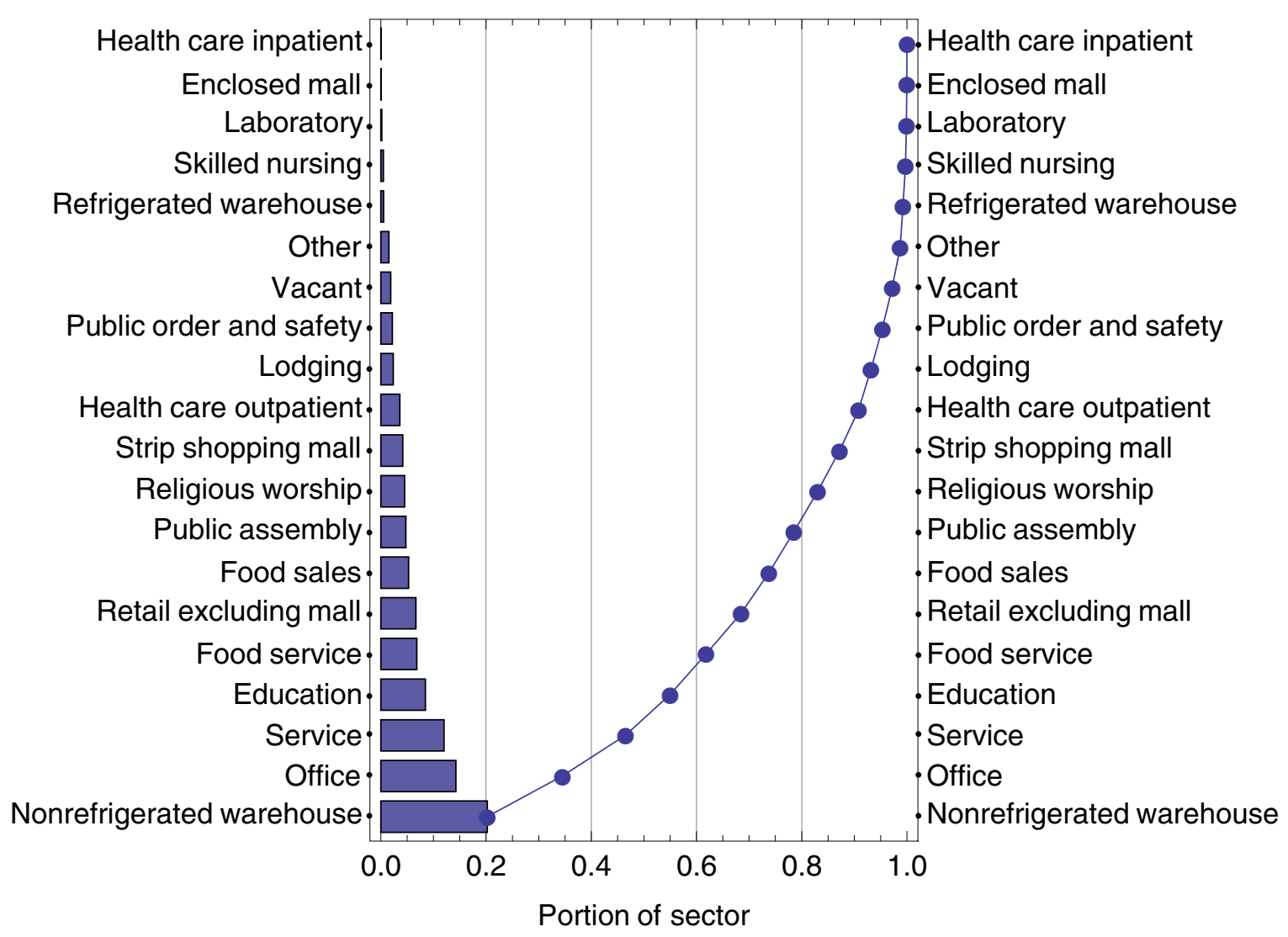

Figure 2-2 Distribution of number of buildings built since 1990 by subsector: 2003 CBECS data (EIA 2006) 


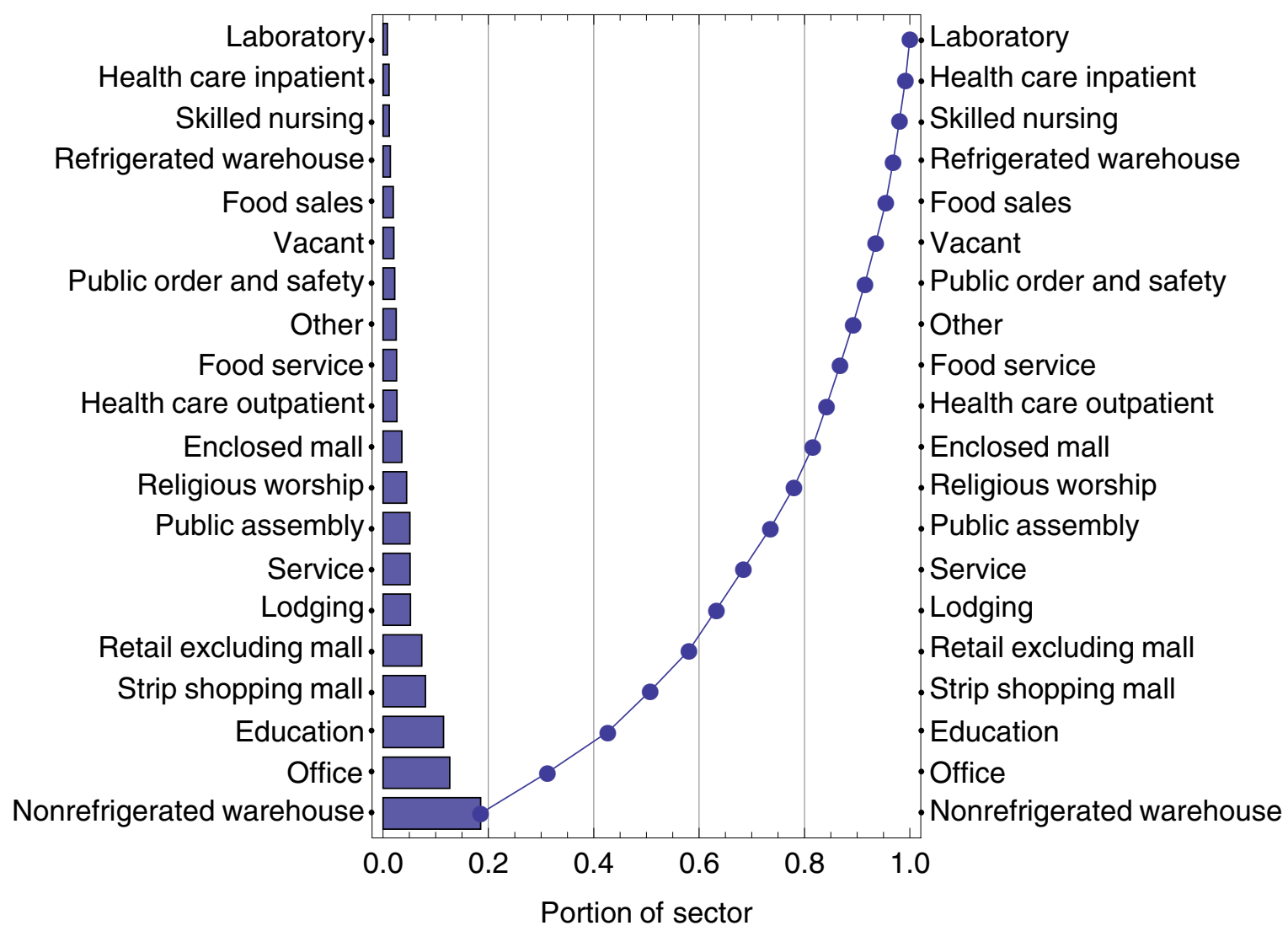

Figure 2-3 Distribution of floor area in buildings built since 1990, by subsector: 2003 CBECS data (EIA 2006) 


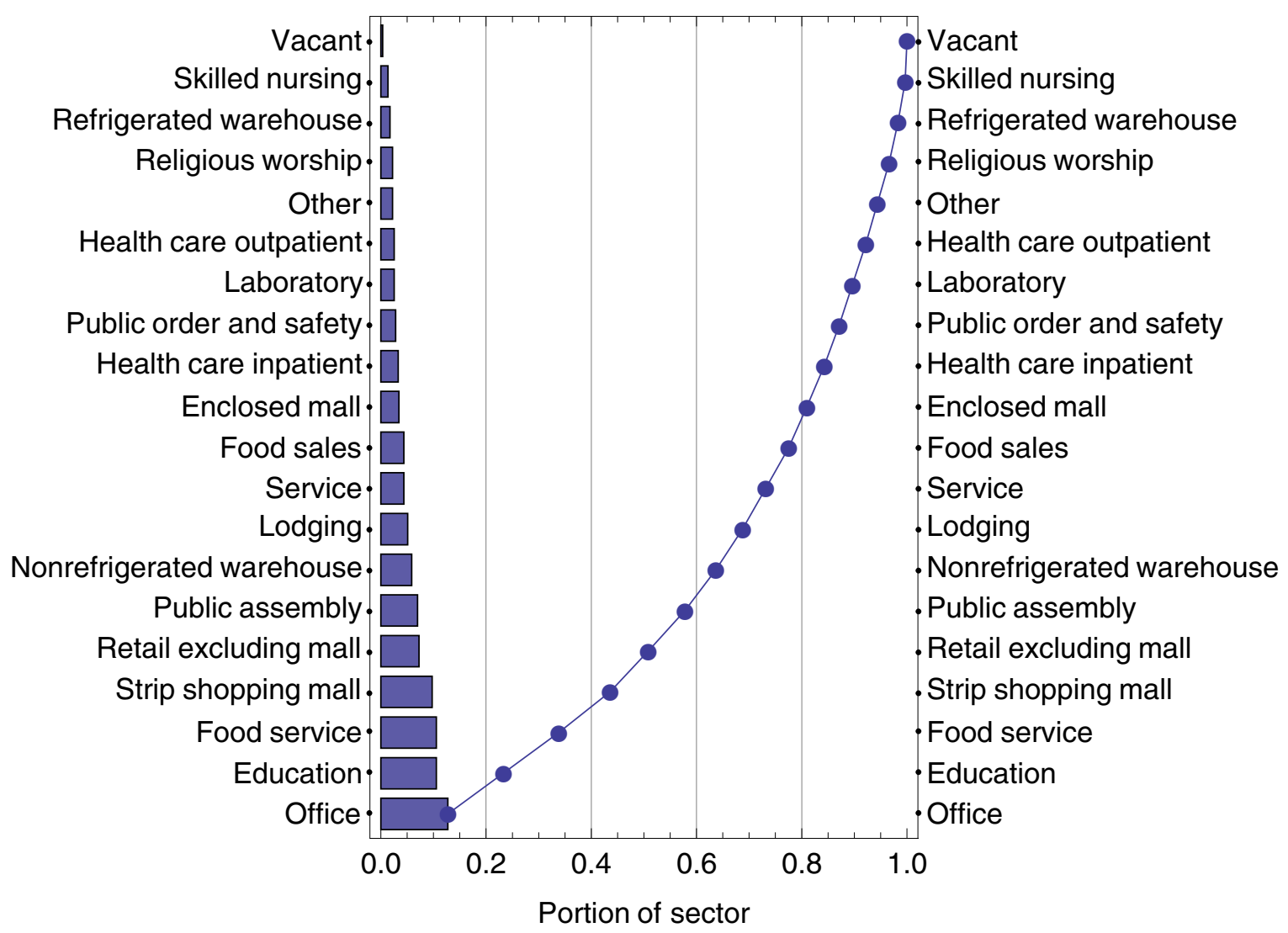

Figure 2-4 Distribution of energy use in buildings built since 1990, by subsector: 2003 CBECS data (EIA 2006)

\subsection{Moving toward Zero Energy}

Today's commercial buildings employ complex and diverse technologies in their design, construction, operation, and maintenance. As pointed out in High-Performance Commercial Buildings: A Technology Roadmap (DOE 2000), building materials, components, and subsystems have been designed and implemented based on standardized criteria that are largely independent of one another.

In the coming decades, these buildings can be dramatically reshaped by combining the results of research and product development in a variety of fields — energy-efficient building shells; HVAC equipment; lighting; daylighting; windows; passive and active solar; PV power systems; fuel cells; advanced sensors and controls; and combined heating, cooling, and power. Such technologies, together with a wholebuilding design approach (sometimes called "systems engineering" or "integrated design") that takes advantage of interactions between building systems and components, will enable commercial buildings that serve their needs and meet national goals of environmental protection, economic growth, and sustainable development. Broad expansion of the U.S. economy can be expected to lead to increases in commercial building floor area. Decoupling the energy implications of this growth becomes important so that energy supply or cost constraints do not hinder economic growth. 
A whole-building approach considers all the building components and subsystems together, along with their potential interactions and impacts on occupants. The fundamental goal is to optimize the building's performance in terms of comfort, functionality, energy efficiency, resource efficiency, economic return, and life-cycle value. The whole-building approach crosses disciplines and requires that planning, siting, aesthetic design, equipment and material selection, financing, construction, commissioning, and longterm operation and maintenance be integrated.

Implementing a whole-building approach can enhance air quality, lighting, thermal environment and other key aspects of a building's indoor environment. A commercial building is typically a unique structure created for a specific location to meet a specific set of architectural programmatic requirements. As a result, developing a high-performance commercial building requires an integrated design team that fosters close collaboration between owners, architects, engineers, financiers, managers and operators, building trade representatives, contractors, and other key players. The starting point is to reach agreement on the architectural program and the goals that will be used to guide decisions.

This kind of integrated building design and construction process departs radically from the approach used historically, in which each discipline in the fragmented development process performs its work largely in isolation from the others. In the best cases this process can optimize individual components of the building, but the resulting building on the whole will be less efficient and more expensive than a building built through integrated design. Widespread adoption of integrated building design will require new mindsets, channels, tools, and methodologies for collaborative communication, problem solving, and decision making across these disciplines. By nature, simulation-based solutions couple the energy dynamics between design solutions to fully examine the potential. Aggregate savings are largely a result of integrated design.

\subsection{Performance Metrics}

Whole-building performance metrics need to be selected so that we are not restricted to "apple-to-apple" technology comparisons. For example, lighting energy end use could be used to compare lighting measures, but a whole-building metric is needed to factor in the heating energy implications of a lighting measure or to compare lighting improvements to thermal insulation improvements. We used the following whole-building metrics, with definitions by Barley et al. (2005), as measures of the use, costs, and environmental implications of energy performance:

- Total site energy is the sum of all the energy used by the building and its occupants. Electricity and gas are combined without regard for their production and delivery. This metric ignores any energy produced by PV panels at the site. Changes in total site energy reflect only the savings associated with reducing consumption.

- Net site energy is similar to total site energy except that the "net" indicates the metric accounts for the energy produced at the site by PV power systems. We used this metric in this study to define when the ZEB goal is met.

- Net source energy includes accounting for PV electricity production but assumes that the energy value of electricity includes a factor for the amount of source energy used to produce, transmit, and distribute the electricity. In our modeling, this electricity fuel factor (site-to-source) varies by state with values from Deru and Torcellini (2007). Source fuel factors are also applied to natural gas.

- Energy cost includes the results of detailed tariff modeling with realistic utility rates calculated for each building model. The costs assume a simple net-metering arrangement for selling excess on-site power. The tariff structures vary by location and reflect all the complexity of demand charges and time-of-use rates. These data were compiled from Web sources and made into EnergyPlus input objects for this project. 
- Equivalent carbon from energy includes the results of detailed modeling of the emissions associated with the energy use. In this assessment, we used emissions factor data at the state level from Deru and Torcellini (2007) for individual types of emissions. Equivalent carbon is modeled by using weighting factors to combine oxides of nitrogen $\left(\mathrm{NO}_{\mathrm{x}}\right)$, methane $\left(\mathrm{CH}_{4}\right)$ and carbon dioxide $\left(\mathrm{CO}_{2}\right)$ (the weighting factors are coded within EnergyPlus and were originally from the Intergovernmental Panel on Climate Change).

- Water from electricity production includes the results of detailed modeling of the water consumed to produce the electricity used in the building. The water factor data developed by NREL (Torcellini, Long, and Judkoff 2004) is used to calculate the water use for electricity production and referred as "energy water" in the results.

- Peak electrical demand includes all uses of electricity and is a measure of the maximum 15minute draw for the year.

The following measures for savings can be used to express these metrics:

- Percent savings is quite common and indicates the performance changes as a fraction of the baseline building performance. In this study, we defined baseline performance as the minimum performance predicted for a building that just conforms to Standard 90.1-2004 (ASHRAE 2004a).

- Use intensity savings can be expressed in either English or SI units. The term indicates the performance change as the magnitude of the decrease in EUI.

- Total savings can also be expressed in English or SI units and uses floor areas and weighting factors for the entire country or subsector to indicate the aggregated values. 


\section{ANALYSIS METHODOLOGY}

What might be achieved if all commercial buildings strived toward the ZEB goal? How low can energy use go within the sector? What if one were somehow able to apply an aggressive set of known technologies and practices to all the varied types of buildings in the entire U.S. commercial sector? This section explains how NREL generates quantitative answers to these questions by using large sets of detailed energy performance simulations to investigate various scenarios.

Predicting the energy performance of buildings under various scenarios is challenging. Because building energy use is complex, simulation tools are needed to model all the interactions between systems, components, occupants' activities, and weather. Such tools need to model transient behavior because building loads and energy use are highly time dependent and steady-state models can rarely represent them well. Annual simulation periods are needed to accurately account for climate variations. Often the interactions are not entirely intuitive. For example, increasing fenestration area for daylighting in a space adds solar gains, but can reduce lighting loads. This affects heating loads, cooling loads, and fan energy. To study the effect of daylighting on a space, then, all the pieces must be analyzed. In fact, numerous energy efficiency improvements lead to reduced internal heat gains. The extra benefits in terms of energy use reductions and cooling are quite widely understood, but to quantify this extra benefit requires detailed engineering models. NREL selected EnergyPlus as the modeling tool for this project because it is the most advanced and complete whole-building energy simulation tool. A drawback to this tool, however, is the amount of time required to execute a simulation. We use this tool to assess alternate scenarios by comparing the results for baseline building models to the results for similar models that are changed to reflect ZEB technologies and practices.

For an assessment of ZEBs, national-scale results are more valuable. To meet this need, we used an analysis framework with a large number of individual building models that were intended to represent the entire commercial sector. We can use this concept to model the entire sector nationally such that trends across the nation can be studied and the national potential for achieving ZEBs can be identified. We can use this information to identify target subsectors in a large and diverse energy sector that are important in the context of achieving the ZEB goal.

This section summarizes the methodology used to assess the technical potential for energy performance in the commercial building sector.

\subsection{Analysis Framework}

Whole-building simulation has been in use for approximately 30 years, and researchers have used such tools to represent large portions of the building stock. Some of the earliest research was conducted by Briggs, Crawley, and others at Pacific Northwest National Laboratory (Briggs, Crawley, and Belzer 1987; Briggs, Crawley, and Schliesing 1992; Crawley and Schliesing 1992). A more current example is research by Huang and Franconi (1999) at Lawrence Berkeley National Laboratory (LBNL), who built on this work. The LBNL researchers focused on modeling component loads (rather than energy use) for the building stock. Moffat (2001) presents a good overview of these methods, which he refers to as stock aggregation, in the context of life cycle analysis and community planning. Large-scale simulation studies are also common in the history of developing codes and standards. The earlier projects demonstrated the utility of running large numbers of detailed models to address certain questions. A unique part of this assessment is focus on new construction across the sector in the context of BT's ZEB goals.

We selected EnergyPlus (Crawley et al. 2001) because it is the contemporary DOE/BT tool that accounts for the complicated interactions between climate, internal gains, building form and fabric, HVAC systems, and renewable energy systems. The simulations are run with EnergyPlus Version 2.0. EnergyPlus is a heavily tested program with formal comparative-testing validation efforts repeated for every release (Judkoff and Neymark 1995; ASHRAE 2004b). 
The basic framework for the modeling study is diagrammed in Figure 3-1. The current ZEB assessment is the second part of a study. The first part of the study is documented in the separate report by Griffith et al. (2008). The analysis framework for the assessment requires an automated approach, because manual methods would not be feasible for such a large number of building models. Our basic process is to take each building in the 2003 CBECS public use data files and create an EnergyPlus model that approximates the building. The 2003 CBECS includes data for 4,820 non-mall buildings and provides weighting factors to indicate how many more such buildings are represented by each entry to form a statistical model of the entire commercial buildings energy sector. Malls are excluded from the study because their characteristics are not described well in the 2003 CBECS public use data. For each building, we used a variety of CBECS data about floor area, number of floors, census division, basic climatic design criteria, PBA, number of employees, operating hours, type of heating and cooling system, type of windows, and many other variables (documented in Griffith et al. 2008). The building descriptions are further augmented for simulation by a number of assignments based on literature data for lighting, outside air, plug loads, refrigeration, and envelope. Some of the detail is generated by using probabilistic (random) assignments. NREL made a key assumption that the CBECS weighting factors were still applicable, although many of the details of the survey buildings are unknown and were therefore generated synthetically. The results from the existing stock models developed in the first phase were then compared to the survey results in an effort to explore the validity of the bottom up method being used. The conclusion of this validation effort is that although the existing stock models could be improved to better match the survey results, the methodology is well suited to modeling the breadth and variety present in the commercial sector. On average, the models agree with the survey results to within $12 \%$, which is well within one (weighted) standard deviation of mean EUI in the survey results. Compared to the survey results, the models have more central tendency. Figure 4-4 includes probability density functions (PDFs) for EUI for the survey and existing stock models.

For the current study, we started with the existing stock models from Griffith et al. (2008) and then applied changes to each as if it were being built new with code-minimum energy performance determined from ASHRAE Standard 90.1-2004 with Appendix G. Each baseline model is then modified to incorporate ZEB technologies and practices under a scenario designed to investigate the opportunities for ZEBs. Alternate scenarios apply changes to the baseline new buildings; others study changes in the context of very high-performance buildings.

The large number of simulations $(115,680)$ requires distributed computing. An NREL-developed research software application called "OptEPlus" was used to simulate all the EnergyPlus models. This application uses distributed computing to manage simulations and collect results. The simulation results (and 2003 CBECS survey data) are processed and loaded into a database for subsequent analyses. Computer routines were developed to automate analyzing simulation results. We use NREL's Linux cluster supercomputer to run up to 40 simulations at a time (in addition to simulations run under Windows on local machines).

\subsection{Baseline and Maximum Technology Scenarios}

The methodology used in this study to assess the technical potential for ZEB involves using EnergyPlus to calculate what would happen if an aggressive set of ZEB technologies and practices were applied to the buildings. The following two scenarios are the primary ones used to help us understand the opportunities for low- and zero-energy buildings relative to current new construction:

- Base is the reference scenario where the prescriptive measures of Standard 90.1-2004 have been applied to the existing stock models (Griffith et al. 2008). These models represent the stock of commercial buildings as if they were built new using minimum-standard levels of performance.

- Max Tech is the basis scenario for analyzing the opportunities for ZEB. This scenario serves as the starting point for others that perturb some aspect of the package to study the relative impact in the $Z E B$ context. This scenario includes improvements in envelope, lighting systems, plug and 
process loads, HVAC, and on-site generation. The performance levels are best-estimate projections for what could be available in the market in 2025. The package does not include changes to the overall geometry of the building or the basic topology of the HVAC system.

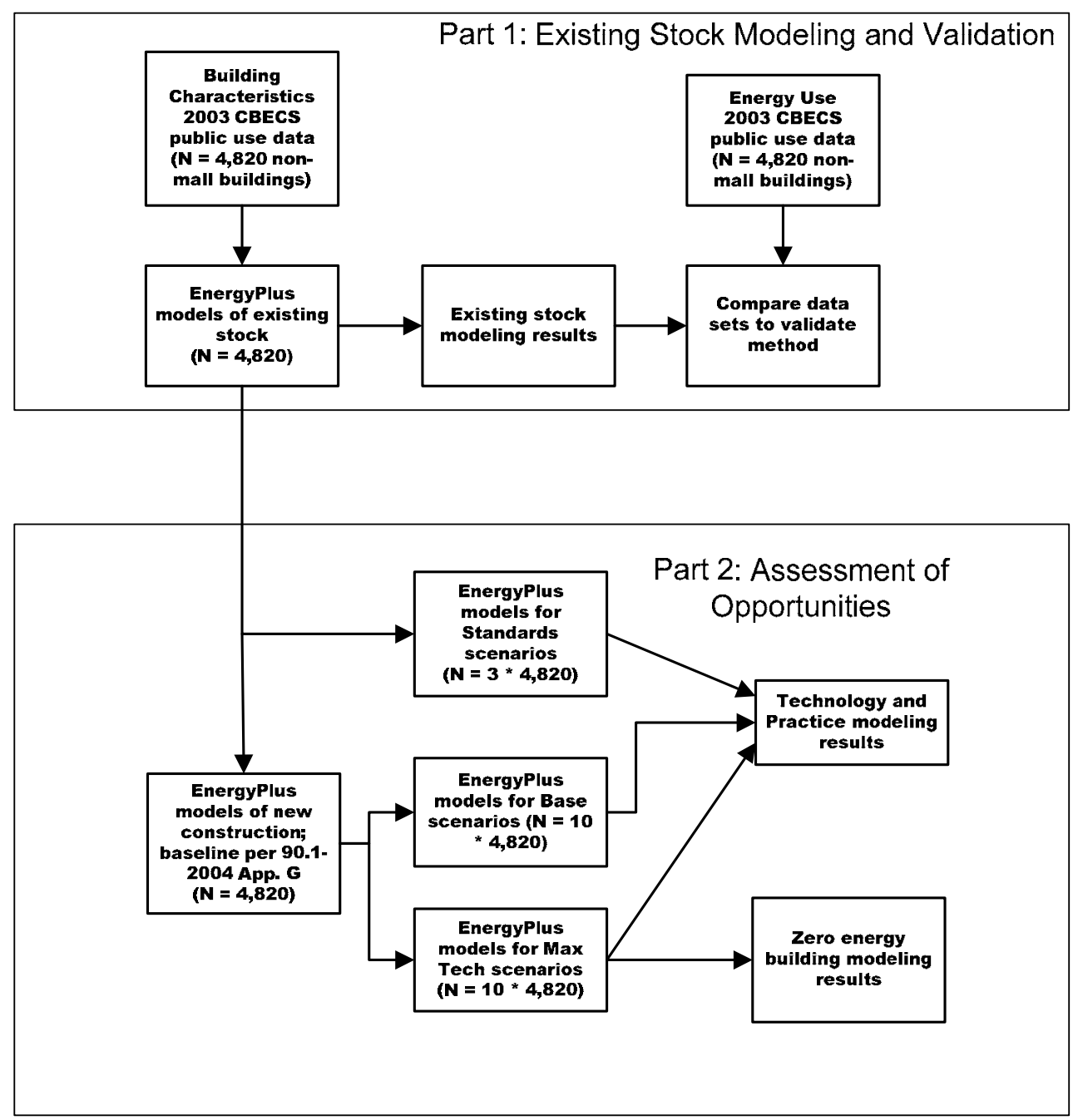

Figure 3-1 Overview of analysis and modeling

Baseline building models are needed as a reference to cast results for the metric "percent savings." For this study, the baseline building models are developed by applying the changes needed to make the models for existing stock comply with ASHRAE Standard 90.1-2004. This includes changing such things as lighting power density (LPD), thermal envelope constructions, mechanical system efficiencies, and setting mechanical ventilation rates to the minimum specified in ASHRAE Standard 62.1-2004. In addition, we alter the HVAC system types in the models to reflect the eight system types specified in Table G3.1.1A of 90.1-2004 Appendix G. Most of the detail generated for the existing stock models is preserved in these models, including: architectural program, plug and process loads, schedules, and geometric form. 
"Maximum Technology," or "Max Tech" for brevity, refers to a scenario used to estimate the technical potential for what is physically possible in the sector. The analysis is basically a bounding study of the limits of energy performance and does not assess market penetration or make detailed projections for how the sector might evolve over the next 20 years. Technical potential is determined from the predictions of whole-building energy performance models that have sets of known technologies and practices applied (with a set of rules discussed below) in EnergyPlus models so that system interactions are included with detailed engineering calculations.

Although there is no expectation that a generic set of rules would apply well to the entire commercial sector, this approach was taken out of practical necessity because the total number of possible sets is enormous. Ideally, each building would receive individual attention, and an optimal set of technologies and practices would be selected that provides the best energy performance for its particular architectural program. We expect that better performance results could be obtained with a search method to identify these best-performing sets, but such optimization capabilities would be difficult and computationally expensive to attempt with the large $(\mathrm{N}=4,820)$ sample size used to model the entire sector. Therefore, we developed a single set of technologies and practices for the scenario and applied them more or less uniformly to all the baseline buildings. However, technologies such as overhangs and insulation vary with climate.

The sets of technologies and practices are limited to those that can be modeled in EnergyPlus and can be automatically generated. EnergyPlus has far more capability than what is made available for bulk analyses through the preprocessor. Many technologies (dynamic insulation, air-flow windows, dedicated outside air systems, cogeneration with desiccant-based cooling, water-side economizers, under-floor air distribution, ground source heat pumps, natural and hybrid ventilation, thermal storage, radiant heating and cooling, and others) are under development that might well be considered in the future scenarios and that we would have preferred to include in the "Max Tech" scenarios. However, there were not sufficient resources to add them all to EnergyPlus. One result of this compromise is that the Max Tech scenarios tend to use technologies and practices that are available and in use today, though not necessarily with the optimistic performance characteristics used for the Max Tech scenario. Another result of the simplifications needed is that the building footprints are rectangles and the models use five thermal zones per floor with uniform internal loading.

"Max Tech" here is just a name given to high-performance scenarios in a modeling study and is not meant to imply that better energy performance is not physically possible. Because of the practical limitations imposed by using a generic set of rules and the challenges of modeling advanced technologies and practices in EnergyPlus, the design of the study is expected to produce conservative results and somewhat underestimate the maximum technical potential. Somewhat lower energy performance is expected because of limits on what could be accomplished in the study and because some of the input assumptions indirectly account for market situations. For example, it is theoretically possible to construct buildings in northern Minnesota and southern Florida with the same maximum level of thermal insulation; however, in practice it is realistic to expect insulation levels will vary by climate. This approach was taken in developing input values (see Section 3.2.1). Another example of indirectly accounting for economics and market realities is the PV modeling assumptions where the future scenario goals are those for amorphous products rather than crystalline.

The packages of ZEB technologies and practices include combinations of a number of energy design measures. The individual technology areas are discussed in separate subsections on thermal envelope, lighting, plug and process loads, HVAC, refrigeration, and solar electric systems. The following section discusses various alternate scenarios used to investigate specific technologies and practices in more detail.

\subsubsection{Envelope}

Layer-by-layer descriptions of the constructions of exterior surfaces and a separate parameter for the rate of infiltration are used to model the building thermal envelope in EnergyPlus. The targeted U-factors for 
the opaque thermal envelope are listed in Table 3-1 through Table 3-7. The baseline scenario uses codeminimum performance defined by the assembly maximum U-factor in ASHRAE Standard 90.1-2004 and varies by climate zone (see Figure 4-8) and the type of construction. The Max Tech scenario uses the performance levels from a draft version of Standard 189P. Although in theory, the lowest U-factors for climate zones 7 and 8 could also be built in the more moderate climates, the approach taken in this study is to adjust values by climate for more realistic analysis. The type of construction is carried forward from what was defined for the existing stock models using the CBECS variables for wall construction material (WLCNS8) and roof construction material (RFCNS8). Climate zone 8 is not actually used because no buildings in the modeling study are located there. These are the target U-factors used in an iterative process to refine the material properties in the layer-by-layer descriptions to just match the assembly performance level. The U-factors here include standard film coefficients.

Table 3-1 Opaque Envelope Maximum Assembly U-Factors by Climate Zone: Mass Walls above Grade

\begin{tabular}{|c|c|c|}
\hline Climate Zones & $\begin{array}{c}\text { Baseline } \\
\text { Btu/h} \cdot \mathrm{ft}^{2} \cdot{ }^{\circ} \mathrm{F}\left(\mathrm{W} / \mathrm{m}^{2} \cdot \mathrm{K}\right)\end{array}$ & 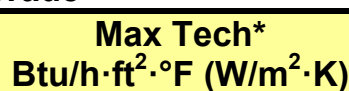 \\
\hline $1 \mathrm{~A}, 1 \mathrm{~B}$ & 0.580 (3.29) & $0.151(0.86)$ \\
\hline $2 \mathrm{~A}, 2 \mathrm{~B}$ & $0.580(3.29)$ & $0.123(0.70)$ \\
\hline $3 A, 3 B, 3 C$ & $0.151(0.86)$ & $0.104(0.59)$ \\
\hline $4 \mathrm{~A}, 4 \mathrm{~B}, 4 \mathrm{C}$ & $0.151(0.86)$ & $0.090(0.51)$ \\
\hline $5 A, 5 B, 5 C$ & $0.123(0.70)$ & $0.080(0.45)$ \\
\hline $6 \mathrm{~A}, 6 \mathrm{~B}$ & $0.104(0.59)$ & $0.071(0.40)$ \\
\hline 7 & $0.090(0.51)$ & $0.060(0.34)$ \\
\hline 8 & $0.080(0.45)$ & $0.060(0.34)$ \\
\hline
\end{tabular}

* Max Tech was established based on 189P.

Table 3-2 Opaque Envelope Maximum Assembly U-Factors by Climate Zone: Metal Building Walls above Grade

\begin{tabular}{|c|c|c|}
\hline Climate Zones & 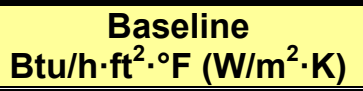 & $\begin{array}{c}\text { Max Tech } \\
\text { Btu/h: } \mathrm{ft}^{2} \cdot{ }^{\circ} \mathrm{F}\left(\mathrm{W} / \mathrm{m}^{2} \cdot \mathrm{K}\right)\end{array}$ \\
\hline $1 \mathrm{~A}, 1 \mathrm{~B}$ & $0.113(0.64)$ & $0.070(0.40)$ \\
\hline $2 \mathrm{~A}, 2 \mathrm{~B}$ & $0.113(0.64)$ & $0.070(0.40)$ \\
\hline $3 A, 3 B, 3 C$ & $0.113(0.64)$ & $0.070(0.40)$ \\
\hline $4 \mathrm{~A}, 4 \mathrm{~B}, 4 \mathrm{C}$ & $0.113(0.64)$ & $0.061(0.35)$ \\
\hline $5 A, 5 B, 5 C$ & $0.113(0.64)$ & $0.061(0.35)$ \\
\hline $6 \mathrm{~A}, 6 \mathrm{~B}$ & $0.113(0.64)$ & $0.061(0.35)$ \\
\hline 7 & $0.057(0.32)$ & $0.052(0.30)$ \\
\hline 8 & $0.057(0.32)$ & $0.052(0.30)$ \\
\hline
\end{tabular}


Table 3-3 Opaque Envelope Maximum Assembly U-Factors by Climate Zone: Steel-Framed Walls above Grade

\begin{tabular}{|c|c|c|}
\hline Climate Zones & $\begin{array}{c}\text { Baseline } \\
\text { Btu/h.ft }{ }^{2} \cdot{ }^{\circ}\left(\mathrm{W} / \mathrm{m}^{2} \cdot \mathrm{K}\right)\end{array}$ & $\begin{array}{c}\text { Max Tech } \\
\text { Btu/h} \cdot \mathrm{ft}^{2} \cdot{ }^{\circ} \mathrm{F}\left(\mathrm{W} / \mathrm{m}^{2} \cdot \mathrm{K}\right)\end{array}$ \\
\hline $1 \mathrm{~A}, 1 \mathrm{~B}$ & $0.124(0.70)$ & $0.077(0.44)$ \\
\hline $2 \mathrm{~A}, 2 \mathrm{~B}$ & $0.124(0.70)$ & $0.077(0.44)$ \\
\hline $3 \mathrm{~A}, 3 \mathrm{~B}, 3 \mathrm{C}$ & $0.124(0.70)$ & $0.077(0.44)$ \\
\hline $4 \mathrm{~A}, 4 \mathrm{~B}, 4 \mathrm{C}$ & $0.124(0.70)$ & $0.055(0.31)$ \\
\hline $5 A, 5 B, 5 C$ & $0.084(0.48)$ & $0.055(0.31)$ \\
\hline $6 \mathrm{~A}, 6 \mathrm{~B}$ & $0.084(0.48)$ & $0.055(0.31)$ \\
\hline 7 & $0.064(0.36)$ & $0.055(0.31)$ \\
\hline 8 & $0.064(0.36)$ & $0.055(0.31)$ \\
\hline
\end{tabular}

Table 3-4 Opaque Envelope Maximum Assembly U-Factors by Climate Zone: Wood-Framed and Other Walls above Grade

\begin{tabular}{|c|c|c|}
\hline Climate Zones & $\begin{array}{c}\text { Baseline } \\
\text { Btu/h} \cdot \mathrm{ft}^{2} \cdot{ }^{\circ} \mathrm{F}\left(\mathrm{W} / \mathrm{m}^{2} \cdot \mathrm{K}\right) \\
\end{array}$ & $\begin{array}{c}\text { Max Tech } \\
\text { Btu/h} \cdot \mathrm{ft}^{2} \cdot{ }^{\circ} \mathrm{F}\left(\mathrm{W} / \mathrm{m}^{2} \cdot \mathrm{K}\right) \\
\end{array}$ \\
\hline $1 \mathrm{~A}, 1 \mathrm{~B}$ & $0.089(0.51)$ & $0.064(0.36)$ \\
\hline $2 \mathrm{~A}, 2 \mathrm{~B}$ & $0.089(0.51)$ & $0.064(0.36)$ \\
\hline $3 \mathrm{~A}, 3 \mathrm{~B}, 3 \mathrm{C}$ & $0.089(0.51)$ & $0.064(0.36)$ \\
\hline $4 \mathrm{~A}, 4 \mathrm{~B}, 4 \mathrm{C}$ & $0.089(0.51)$ & $0.064(0.36)$ \\
\hline $5 A, 5 B, 5 C$ & $0.089(0.51)$ & $0.051(0.29)$ \\
\hline $6 \mathrm{~A}, 6 \mathrm{~B}$ & $0.089(0.51)$ & $0.045(0.26)$ \\
\hline 7 & $0.089(0.51)$ & $0.045(0.26)$ \\
\hline 8 & $0.051(0.29)$ & $0.032(0.18)$ \\
\hline
\end{tabular}

Table 3-5 Opaque Envelope Maximum Assembly U-Factors by Climate Zone: Insulation Entirely above Deck Roofs

\begin{tabular}{|c|c|c|}
\hline Climate Zones & $\begin{array}{c}\text { Baseline } \\
\text { Btu/h} \cdot \mathrm{ft}^{2} \cdot{ }^{\circ} \mathrm{F}\left(\mathrm{W} / \mathrm{m}^{2} \cdot \mathrm{K}\right)\end{array}$ & $\begin{array}{c}\text { Max Tech } \\
\text { Btu/h} \cdot \mathrm{ft}^{2} \cdot{ }^{\circ} \mathrm{F}\left(\mathrm{W} / \mathrm{m}^{2} \cdot \mathrm{K}\right)\end{array}$ \\
\hline $1 \mathrm{~A}, 1 \mathrm{~B}$ & $0.063(0.36)$ & $0.048(0.27)$ \\
\hline $2 \mathrm{~A}, 2 \mathrm{~B}$ & $0.063(0.36)$ & $0.039(0.22)$ \\
\hline $3 \mathrm{~A}, 3 \mathrm{~B}, 3 \mathrm{C}$ & $0.063(0.36)$ & $0.039(0.22)$ \\
\hline $4 \mathrm{~A}, 4 \mathrm{~B}, 4 \mathrm{C}$ & $0.063(0.36)$ & $0.039(0.22)$ \\
\hline $5 A, 5 B, 5 C$ & $0.063(0.36)$ & $0.039(0.22)$ \\
\hline $6 \mathrm{~A}, 6 \mathrm{~B}$ & $0.063(0.36)$ & $0.032(0.18)$ \\
\hline 7 & $0.063(0.36)$ & $0.028(0.16)$ \\
\hline 8 & $0.048(0.27)$ & $0.028(0.16)$ \\
\hline
\end{tabular}


Table 3-6 Opaque Envelope Maximum Assembly U-Factors by Climate Zone: Metal Building Roofs

\begin{tabular}{|c|c|c|}
\hline Climate Zones & $\begin{array}{c}\text { Baseline } \\
\text { Btu } / \mathrm{h} \cdot \mathrm{ft}^{2} \cdot{ }^{\circ} \mathrm{F}\left(\mathrm{W} / \mathrm{m}^{2} \cdot \mathrm{K}\right)\end{array}$ & $\begin{array}{c}\text { Max Tech \& Standard 189P } \\
\text { Btu/h } \cdot \mathrm{ft}^{2} \cdot{ }^{\circ} \mathrm{F}\left(\mathrm{W} / \mathrm{m}^{2} \cdot \mathrm{K}\right)\end{array}$ \\
\hline$\overline{1 \mathrm{~A}, 1 \mathrm{~B}}$ & $0.065(0.37)$ & $0.049(0.28)$ \\
\hline $2 \mathrm{~A}, 2 \mathrm{~B}$ & $0.065(0.37)$ & $0.041(0.23)$ \\
\hline $3 \mathrm{~A}, 3 \mathrm{~B}, 3 \mathrm{C}$ & $0.065(0.37)$ & $0.041(0.23)$ \\
\hline $4 \mathrm{~A}, 4 \mathrm{~B}, 4 \mathrm{C}$ & $0.065(0.37)$ & $0.041(0.23)$ \\
\hline $5 \mathrm{~A}, 5 \mathrm{~B}, 5 \mathrm{C}$ & $0.065(0.37)$ & $0.041(0.23)$ \\
\hline $6 \mathrm{~A}, 6 \mathrm{~B}$ & $0.065(0.37)$ & $0.032(0.18)$ \\
\hline 7 & $0.065(0.37)$ & $0.028(0.16)$ \\
\hline 8 & $0.049(0.28)$ & $0.028(0.16)$ \\
\hline
\end{tabular}

Table 3-7 Opaque Envelope Maximum Assembly U-Factors by Climate Zone: Attics and Other Roofs

\begin{tabular}{|c|c|c|}
\hline Climate Zones & $\begin{array}{c}\text { Baseline Btu/h} \cdot \mathrm{ft}^{2} \cdot{ }^{\circ} \mathrm{F} \\
\left(\mathrm{W} / \mathrm{m}^{2} \cdot \mathrm{K}\right)\end{array}$ & $\begin{array}{l}\text { Max Tech \& Standard 189P } \\
\text { Btu/h. } \mathrm{ft}^{2} \cdot{ }^{\circ} \mathrm{F}\left(\mathrm{W} / \mathrm{m}^{2} \cdot \mathrm{K}\right)\end{array}$ \\
\hline $1 \mathrm{~A}, 1 \mathrm{~B}$ & $0.034(0.19)$ & $0.027(0.15)$ \\
\hline $2 \mathrm{~A}, 2 \mathrm{~B}$ & $0.034(0.19)$ & $0.021(0.12)$ \\
\hline $3 A, 3 B, 3 C$ & $0.034(0.19)$ & $0.021(0.12)$ \\
\hline $4 \mathrm{~A}, 4 \mathrm{~B}, 4 \mathrm{C}$ & $0.034(0.19)$ & $0.021(0.12)$ \\
\hline $5 A, 5 B, 5 C$ & $0.034(0.19)$ & $0.021(0.12)$ \\
\hline $6 \mathrm{~A}, 6 \mathrm{~B}$ & $0.027(0.15)$ & $0.021(0.12)$ \\
\hline 7 & $0.027(0.15)$ & $0.017(0.10)$ \\
\hline 8 & $0.027(0.15)$ & $0.017(0.10)$ \\
\hline
\end{tabular}

Window fenestration U-factors for the Baseline and Standard 189P scenarios are listed in Table 3-8 through Table 3-12 for different window to wall ratios. Individual tables list assembly U-factors by climate zone and for different scenarios. The values are from ASHARE Standard 90.1-2004 (baseline) and draft Standard 189P. The values in these tables vary little, and although we could collapse data into a more compact form, we preserve the structure used in the standards for consistency. Unlike the opaque envelope, the Max Tech scenarios do not reuse Standard 189P for the windows. These are the target Ufactors used in an iterative process to refine the material properties in the layer-by-layer descriptions to just match the assembly performance level. 
Table 3-8 Fenestration Maximum Assembly U-Factors by Climate Zone: Fixed Vertical Glazing $0 \%$ to $10 \%$ of Wall

\begin{tabular}{|l|c|c|}
\hline Climate Zones & $\begin{array}{c}\text { Baseline } \\
\mathbf{B t u}^{\mathbf{W}} \cdot \mathbf{f t}^{2} \cdot{ }^{\circ} \mathbf{F} \\
\left(\mathbf{W} / \mathbf{m}^{2} \cdot \mathbf{K}\right)\end{array}$ & $\begin{array}{c}\text { Standard 189P Metal Frame } \\
\text { Btu/h} \cdot \mathbf{f t}^{2} \cdot{ }^{\circ} \mathbf{F}\left(\mathbf{W} / \mathbf{m}^{2} \cdot \mathbf{K}\right)\end{array}$ \\
\hline 1A, 1B & $1.22(6.93)$ & $1.20(6.81)$ \\
\hline $2 \mathrm{~A}, 2 \mathrm{~B}$ & $1.22(6.93)$ & $0.75(4.26)$ \\
\hline $3 \mathrm{~A}, 3 \mathrm{~B}$ & $0.57(3.24)$ & $0.55(3.12)$ \\
\hline $3 \mathrm{C}$ & $1.22(6.93)$ & $0.55(3.12)$ \\
\hline $4 \mathrm{~A}, 4 \mathrm{~B}, 4 \mathrm{C}$ & $0.57(3.24)$ & $0.45(2.56)$ \\
\hline $5 \mathrm{~A}, 5 \mathrm{~B}, 5 \mathrm{C}$ & $0.57(3.24)$ & $0.45(2.56)$ \\
\hline $6 \mathrm{~A}, 6 \mathrm{~B}$ & $0.57(3.24)$ & $0.45(2.56)$ \\
\hline 7 & $0.57(3.24)$ & $0.35(1.99)$ \\
\hline 8 & $0.46(2.61)$ & $0.35(1.99)$ \\
\hline
\end{tabular}

Table 3-9 Fenestration Maximum Assembly U-Factors by Climate Zone: Fixed Vertical Glazing $10.1 \%$ to $20 \%$ of Wall

\begin{tabular}{|l|c|c|}
\hline Climate Zones & $\begin{array}{c}\text { Baseline } \\
\text { Btu/h } \mathbf{f t}^{2} \cdot{ }^{\circ} \mathbf{F}\left(\mathbf{W} / \mathbf{m}^{2} \cdot \mathbf{K}\right)\end{array}$ & $\begin{array}{c}\text { Standard 189P Metal Frame } \\
\mathbf{B t u} / \mathbf{h} \cdot \mathbf{f t}^{2} \cdot{ }^{\circ} \mathbf{F}\left(\mathbf{W} / \mathbf{m}^{2} \cdot \mathbf{K}\right)\end{array}$ \\
\hline 1A, 1B & $1.22(6.93)$ & $1.20(6.81)$ \\
\hline $2 \mathrm{~A}, 2 \mathrm{~B}$ & $1.22(6.93)$ & $0.75(4.26)$ \\
\hline $3 \mathrm{~A}, 3 \mathrm{~B}$ & $0.57(3.24)$ & $0.55(3.12)$ \\
\hline $3 \mathrm{C}$ & $1.22(6.93)$ & $0.55(3.12)$ \\
\hline $4 \mathrm{~A}, 4 \mathrm{~B}, 4 \mathrm{C}$ & $0.57(3.24)$ & $0.45(2.56)$ \\
\hline $5 \mathrm{~A}, 5 \mathrm{~B}, 5 \mathrm{C}$ & $0.57(3.24)$ & $0.45(2.56)$ \\
\hline $6 \mathrm{~A}, 6 \mathrm{~B}$ & $0.57(3.24)$ & $0.45(2.56)$ \\
\hline 7 & $0.57(3.24)$ & $0.35(1.99)$ \\
\hline 8 & $0.46(2.61)$ & $0.35(1.99)$ \\
\hline
\end{tabular}

Table 3-10 Fenestration Maximum Assembly U-Factors by Climate Zone: Fixed Vertical Glazing $20.1 \%$ to $30 \%$ of Wall

\begin{tabular}{|c|c|c|}
\hline $\begin{array}{l}\text { Climate } \\
\text { Zones }\end{array}$ & $\begin{array}{c}\text { Baseline } \\
\text { Btu/h} \cdot \mathrm{ft}^{2} \cdot{ }^{\circ} \mathrm{F}\left(\mathrm{W} / \mathrm{m}^{2} \cdot \mathrm{K}\right)\end{array}$ & $\begin{array}{c}\text { Standard 189P Metal Frame } \\
\text { Btu } / \mathrm{h} \cdot \mathrm{ft}^{2} \cdot{ }^{\circ} \mathrm{F}\left(\mathrm{W} / \mathrm{m}^{2} \cdot \mathrm{K}\right)\end{array}$ \\
\hline$\overline{1 \mathrm{~A}, 1 \mathrm{~B}}$ & $1.22(6.93)$ & $1.20(6.81)$ \\
\hline $2 A, 2 B$ & $1.22(6.93)$ & $0.75(4.26)$ \\
\hline $3 A, 3 B$ & $0.57(3.24)$ & $0.55(3.12)$ \\
\hline $3 C$ & $1.22(6.93)$ & $0.55(3.12)$ \\
\hline $4 \mathrm{~A}, 4 \mathrm{~B}, 4 \mathrm{C}$ & $0.57(3.24)$ & $0.45(2.56)$ \\
\hline $5 A, 5 B, 5 C$ & 0.57 (3.24) & $0.45(2.56)$ \\
\hline $6 \mathrm{~A}, 6 \mathrm{~B}$ & $0.57(3.24)$ & $0.45(2.56)$ \\
\hline 7 & $0.57(3.24)$ & 0.35 (1.99) \\
\hline 8 & $0.46(2.61)$ & 0.35 (1.99) \\
\hline
\end{tabular}


Table 3-11 Fenestration Maximum Assembly U-Factors by Climate Zone: Fixed Vertical Glazing $30.1 \%$ to $40 \%$ of wall

\begin{tabular}{|c|c|c|}
\hline Climate Zones & $\begin{array}{c}\text { Baseline } \\
\text { Btu } / \mathrm{h} \cdot \mathrm{ft}^{2} \cdot{ }^{\circ} \mathrm{F}\left(\mathrm{W} / \mathrm{m}^{2} \cdot \mathrm{K}\right)\end{array}$ & $\begin{array}{c}\text { Standard 189P Metal Frame } \\
\text { Btu } / \mathrm{h} \cdot \mathrm{ft}^{2} \cdot{ }^{\circ} \mathrm{F}\left(\mathrm{W} / \mathrm{m}^{2} \cdot \mathrm{K}\right)\end{array}$ \\
\hline $1 \mathrm{~A}, 1 \mathrm{~B}$ & $1.22(6.93)$ & $101.20(6.81)$ \\
\hline $2 \mathrm{~A}, 2 \mathrm{~B}$ & $1.22(6.93)$ & $0.75(4.26)$ \\
\hline $3 \mathrm{~A}, 3 \mathrm{~B}$ & $0.57(3.24)$ & $0.55(3.12)$ \\
\hline $3 \mathrm{C}$ & $1.22(6.93)$ & $0.55(3.12)$ \\
\hline $4 \mathrm{~A}, 4 \mathrm{~B}, 4 \mathrm{C}$ & $0.57(3.24)$ & $0.45(2.56)$ \\
\hline $5 A, 5 B, 5 C$ & $0.57(3.24)$ & $0.45(2.56)$ \\
\hline $6 \mathrm{~A}, 6 \mathrm{~B}$ & $0.57(3.24)$ & $0.45(2.56)$ \\
\hline 7 & $0.57(3.24)$ & $0.35(1.99)$ \\
\hline 8 & $0.46(2.61)$ & $0.35(1.99)$ \\
\hline
\end{tabular}

Table 3-12 Fenestration Maximum Assembly U-Factors by Climate Zone: Fixed Vertical Glazing $40.1 \%$ to $100 \%$ of Wall

\begin{tabular}{|l|c|c|}
\hline Climate Zones & $\begin{array}{c}\text { Baseline } \\
\text { Btu/h· } \mathbf{f t}^{2} \cdot{ }^{\circ} \mathbf{F}\left(\mathbf{W} / \mathbf{m}^{2} \cdot \mathbf{K}\right)\end{array}$ & $\begin{array}{c}\text { Standard 189P Metal Frame } \\
\mathbf{B t u} / \mathbf{h} \cdot \mathbf{f t}^{2} \cdot{ }^{\circ} \mathbf{F}\left(\mathbf{W} / \mathbf{m}^{2} \cdot \mathbf{K}\right)\end{array}$ \\
\hline \hline A, 1B & $1.22(6.93)$ & $1.20(6.81)$ \\
\hline $2 \mathrm{~A}, 2 \mathrm{~B}$ & $1.22(6.93)$ & $0.75(4.26)$ \\
\hline $3 \mathrm{~A}, 3 \mathrm{~B}$ & $0.46(2.61)$ & $0.55(3.12)$ \\
\hline $3 \mathrm{C}$ & $1.22(6.93)$ & $0.55(3.12)$ \\
\hline $4 \mathrm{~A}, 4 \mathrm{~B}, 4 \mathrm{C}$ & $0.46(2.61)$ & $0.45(2.56)$ \\
\hline $5 \mathrm{~A}, 5 \mathrm{~B}, 5 \mathrm{C}$ & $0.46(2.61)$ & $0.45(2.56)$ \\
\hline $6 \mathrm{~A}, 6 \mathrm{~B}$ & $0.46(2.61)$ & $0.45(2.56)$ \\
\hline 7 & $0.46(2.61)$ & $0.35(1.99)$ \\
\hline 8 & $0.35(1.99)$ & $0.35(1.99)$ \\
\hline
\end{tabular}

Window fenestration solar heat gain coefficients (SHGC) for the Baseline and Standard 189P scenarios are listed in 
Table 3-13 through Table 3-17 for different window to wall ratios. Individual tables list SHGCs by climate zone and for different scenarios. The values are from 90.1-2004 (baseline) and draft Standard 189P. These are the target SHGC values used in an iterative process to refine the material properties in the layer-by-layer descriptions to just match the assembly performance level. Windows are modeled as horizontal bands and the effects of frames are not modeled explicitly, only as part of the assembly targets. 
Table 3-13 Fenestration Maximum Assembly SHGC by Climate Zone: Fixed Vertical Glazing $0 \%$ to $10 \%$ of Wall

\begin{tabular}{|l|c|c|}
\hline \multicolumn{1}{|c|}{ Climate Zones } & Baseline & Standard 189P \\
\hline \hline A, $1 B$ & 0.25 & 0.25 \\
\hline $2 A, 2 B$ & 0.25 & 0.25 \\
\hline $3 A, 3 B$ & 0.39 & 0.25 \\
\hline $3 C$ & 0.61 & 0.25 \\
\hline $4 A, 4 B, 4 C$ & 0.39 & 0.35 \\
\hline $5 A, 5 B, 5 C$ & 0.49 & 0.35 \\
\hline $6 A, 6 B$ & 0.49 & 0.40 \\
\hline 7 & 0.49 & 0.45 \\
\hline 8 & 0.49 & 0.45 \\
\hline
\end{tabular}

Table 3-14 Fenestration Maximum Assembly SHGC by Climate Zone: Fixed Vertical Glazing $10.1 \%$ to $20 \%$ of Wall

\begin{tabular}{|l|c|c|}
\hline \multicolumn{1}{|c|}{ Climate Zones } & Baseline & Standard 189P \\
\hline 1A, 1B & 0.25 & 0.25 \\
\hline $2 A, 2 B$ & 0.25 & 0.25 \\
\hline $3 A, 3 B$ & 0.25 & 0.25 \\
\hline $3 C$ & 0.39 & 0.25 \\
\hline $4 A, 4 B, 4 C$ & 0.39 & 0.35 \\
\hline $5 A, 5 B, 5 C$ & 0.39 & 0.35 \\
\hline $6 A, 6 B$ & 0.39 & 0.40 \\
\hline 7 & 0.49 & 0.45 \\
\hline 8 & 0.49 & 0.45 \\
\hline
\end{tabular}

Table 3-15 Fenestration Maximum Assembly SHGC by Climate Zone: Fixed Vertical Glazing $20.1 \%$ to $30 \%$ of Wall

\begin{tabular}{|l|c|c|}
\hline \multicolumn{1}{|c|}{ Climate Zones } & Baseline & Standard 189P \\
\hline \hline 1A, 1B & 0.25 & 0.25 \\
\hline $2 A, 2 B$ & 0.25 & 0.25 \\
\hline $3 A, 3 B$ & 0.25 & 0.25 \\
\hline $3 C$ & 0.39 & 0.25 \\
\hline $4 A, 4 B, 4 C$ & 0.39 & 0.35 \\
\hline $5 A, 5 B, 5 C$ & 0.39 & 0.35 \\
\hline $6 A, 6 B$ & 0.39 & 0.40 \\
\hline 7 & 0.49 & 0.45 \\
\hline 8 & 0.49 & 0.45 \\
\hline
\end{tabular}


Table 3-16 Fenestration Maximum Assembly SHGC by Climate Zone: Fixed Vertical Glazing $30.1 \%$ to $-40 \%$ of Wall

\begin{tabular}{|l|c|c|}
\hline \multicolumn{1}{|c|}{ Climate Zones } & Baseline & Standard 189P \\
\hline 1A, 1B & 0.25 & 0.25 \\
\hline $2 A, 2 B$ & 0.25 & 0.25 \\
\hline $3 A, 3 B$ & 0.25 & 0.25 \\
\hline $3 C$ & 0.34 & 0.25 \\
\hline $4 A, 4 B, 4 C$ & 0.39 & 0.35 \\
\hline $5 A, 5 B, 5 C$ & 0.39 & 0.35 \\
\hline $6 A, 6 B$ & 0.39 & 0.40 \\
\hline 7 & 0.49 & 0.45 \\
\hline 8 & 0.49 & 0.45 \\
\hline
\end{tabular}

Table 3-17 Fenestration Maximum Assembly SHGC by Climate Zone: Fixed Vertical Glazing $40.1 \%$ to $100 \%$ of Wall

\begin{tabular}{|l|c|c|}
\hline \multicolumn{1}{|c|}{ Climate Zones } & Baseline & Standard 189P \\
\hline $1 \mathrm{~A}, 1 \mathrm{~B}$ & 0.19 & 0.25 \\
\hline $2 \mathrm{~A}, 2 \mathrm{~B}$ & 0.17 & 0.25 \\
\hline $3 \mathrm{~A}, 3 \mathrm{~B}$ & 0.19 & 0.25 \\
\hline $3 \mathrm{C}$ & 0.20 & 0.25 \\
\hline $4 \mathrm{~A}, 4 \mathrm{~B}, 4 \mathrm{C}$ & 0.25 & 0.35 \\
\hline $5 \mathrm{~A}, 5 \mathrm{~B}, 5 \mathrm{C}$ & 0.26 & 0.35 \\
\hline $6 \mathrm{~A}, 6 \mathrm{~B}$ & 0.26 & 0.40 \\
\hline 7 & 0.36 & 0.45 \\
\hline 8 & 0.49 & 0.45 \\
\hline
\end{tabular}

For the Max Tech scenario, windows are modeled as high-performance switchable glazing systems with low U-factors and dynamic SHGC and visible transmittance. Future high-performance windows are modeled according to the performance goals set forth for the year 2020 in Table 2-42 of BT's multiyear plan (DOE 2007). The SHGC for clear state was changed from 0.6 to 0.4 to tailor the goal specifically for commercial buildings. Table 3-18 lists the performance characteristics for the two ends of the dynamic range. The EnergyPlus modeling controls the dynamic glazings to vary the performance linearly between two states to attempt to meet the illuminance set point for the zone daylight control (using the control mode called "MeetDaylightIlluminanceSetpoint"). For scenarios without daylighting, the control scheme is set to dark whenever cooling is needed (using the on/off control mode called OffNight/OnDayIfCoolingAndHighSolarOnWindow").

Table 3-18 Dynamic Fenestration Performance Ranges

\begin{tabular}{|l|c|c|c|c|}
\hline \multicolumn{1}{|c|}{ State } & SHGC & $\begin{array}{c}\text { Visible } \\
\text { Transmission }\end{array}$ & $\begin{array}{c}\text { U-Factor } \\
\left(\mathbf{W} / \mathbf{m}^{2}-\mathbf{K}\right)\end{array}$ & $\begin{array}{c}\text { U-Factor } \\
\left(\mathrm{Btu}^{\prime} \cdot \mathrm{ft}^{2} \cdot{ }^{\circ} \mathrm{F}\right)\end{array}$ \\
\hline \hline Clear & 0.40 & 0.65 & 0.565 & 0.1 \\
\hline Dark & 0.058 & 0.02 & 0.565 & 0.1 \\
\hline
\end{tabular}

For the Max Tech scenario, rooftop fenestration is added to daylight interior core zones on the top floor of buildings. The fenestration systems are tubular daylighting devices (TDDs) with the following 
performance characteristics: tube diameter of $1.75 \mathrm{ft}(0.5 \mathrm{~m})$, tube length of $3.6 \mathrm{ft}(1.1 \mathrm{~m})$, tube effective thermal resistance of $0.05 \mathrm{~h} \cdot \mathrm{ft}^{2} \cdot \mathrm{F} / \mathrm{Btu}\left(0.28 \mathrm{~m}^{2} \cdot \mathrm{K} / \mathrm{W}\right)$, acrylic dome and diffuser. The TDDs are installed over top-floor core zones at a density of one per $200 \mathrm{ft}^{2}\left(18 \mathrm{~m}^{2}\right)$.

Two input parameters are used to model infiltration rates simply. The main parameter is a volume flow rate per unit area for the exterior envelope. This is augmented by a low level, whole-zone flow rate formulated as air changes per hour $(\mathrm{ACH})$. The infiltration rates are reduced in the Standard 189P and Max Tech scenarios to model the inclusion of thorough and well-installed air barrier systems. The envelope infiltration rates are listed in Table 3-19, where the rate values for $4 \mathrm{~Pa}$ are used in the models for constant, annual average infiltration associated with the exterior envelope.

Table 3-19 Infiltration Rates for Opaque Exterior Envelope Normalized by Wall Area

\begin{tabular}{|c|c|c|c|c|c|}
\hline Units & Pressure & Existing Stock & Base & Standard 189P & Max Tech \\
\hline $\mathrm{m}^{3} / \mathrm{s} / \mathrm{m}^{2}$ & $75 \mathrm{~Pa}$ & $1.8 \mathrm{E}-03$ & $1.8 \mathrm{E}-03$ & $9.0 \mathrm{E}-04$ & $4.5 \mathrm{E}-04$ \\
\hline $\mathrm{cfm} / \mathrm{ft}^{2}$ & $75 \mathrm{~Pa}$ & 0.4 & 0.4 & 0.2 & 0.1 \\
\hline $\mathrm{m}^{3} / \mathrm{s} / \mathrm{m}^{2}$ & $4 \mathrm{~Pa}$ & $2.68 \mathrm{E}-04$ & $2.68 \mathrm{E}-04$ & $1.34 \mathrm{E}-04$ & $6.69 \mathrm{E}-05$ \\
\hline $\mathrm{cfm} / \mathrm{ft}^{2}$ & $4 \mathrm{~Pa}$ & 0.060 & 0.060 & 0.030 & 0.015 \\
\hline
\end{tabular}

\subsubsection{Lighting Systems}

Lighting energy use is modeled by using an installed LPD along with schedules and sometimes daylighting controllers. A more efficient lighting technology is modeled by reducing LPD. Lighting systems of a given LPD are assumed to suffice, and electric lighting designs are not modeled explicitly to determine whether light levels are suitable. Table 3-20 and Table 3-21 list the LPD values for the different scenarios in both IP and SI units. The "Existing" column LPD values are from Navigant's results (from Table 5-11 in DOE 2002) and represent the mean values used in probabilistic assignments. The "baseline" column LPD values are derived from 90.1-2004. For the Max Tech scenario, LPD levels were reduced by $50 \%$ from $90.1-2004$ by following the strategic goals outlined for the Lighting Research and Development activities in section 2.3.1 of the multiyear program plan for BT (DOE 2007). These LPD reductions do not affect refrigerated case lighting. The lighting schedules are modeled from the schedule developed for each building's hours of operation and the CBECS variables for percent lit when open and closed (see Griffith et al. 2008).

Another important aspect of low-energy lighting systems is daylighting. The baseline buildings are assumed to have no daylight harvesting (the lighting energy is determined only by LPD and the lighting schedule). Daylighting systems are a subset of the lighting system and are composed of two parts: controls and architecture. Daylighting controls are modeled in EnergyPlus and reduce electric lighting levels when natural daylight levels are sufficient. A more effective daylighting system will run the electric lights less often over the course of year. EnergyPlus does not model the light levels produced by the electric lighting and assumes that the lighting power entered by the user is sufficient to meet the needs. EnergyPlus does model the penetration of natural light and the controls are triggered by the natural light levels at the location of daylighting reference point used as the sensor. Daylighting control points were added to the geometric center of each thermal zone at a height of $2.5 \mathrm{ft}$. $(0.76 \mathrm{~m})$, except where they would lie directly under rooftop fenestration, in which case they were placed midway between neighboring units. Table 3-22 lists the daylighting control settings for all the models that include daylighting controls. Although lighting needs can vary widely, the value for the daylighting setpoint was selected as a compromise value for all the different types of spaces in the sector. 
Table 3-20 LPDs by PBA for Various Scenarios: IP Units

\begin{tabular}{|c|c|c|c|c|c|c|}
\hline $\begin{array}{l}\text { PBA } \\
\text { Code }\end{array}$ & PBA & $\begin{array}{c}\text { Existing } \\
\left(\mathrm{W} / \mathrm{ft}^{2}\right)\end{array}$ & $\begin{array}{c}\text { Base } \\
\left(\mathrm{W} / \mathrm{ft}^{2}\right)\end{array}$ & $\begin{array}{c}\text { Draft Standard } \\
189 \mathrm{P} \\
(-15 \%)\left(\mathrm{W} / \mathrm{ft}^{2}\right) \\
\end{array}$ & $\begin{array}{c}\text { Max Tech } 20 \% \\
\text { LPD } \\
(-20 \%)\left(\mathrm{W} / \mathrm{ft}^{2}\right) \\
\end{array}$ & $\begin{array}{c}\text { Max Tech } \\
(-50 \%) \\
\left(\mathrm{W} / \mathrm{ft}^{2}\right) \\
\end{array}$ \\
\hline 1 & Vacant & 2.10 & 1.02 & 0.87 & 0.82 & 0.51 \\
\hline 2 & Office/professional & 1.80 & 1.02 & 0.87 & 0.82 & 0.51 \\
\hline 4 & Laboratory & 1.70 & 1.39 & 1.18 & 1.11 & 0.70 \\
\hline 5 & Nonrefrigerated warehouse & 1.40 & 0.84 & 0.71 & 0.67 & 0.42 \\
\hline 6 & Food sales & 1.90 & 1.49 & 1.27 & 1.19 & 0.74 \\
\hline 7 & Public order/safety & 1.30 & 1.02 & 0.87 & 0.82 & 0.51 \\
\hline 8 & Health care (outpatient) & 1.70 & 1.02 & 0.87 & 0.82 & 0.51 \\
\hline 11 & Refrigerated warehouse & 1.40 & 0.84 & 0.71 & 0.67 & 0.42 \\
\hline 12 & Religious worship & 1.40 & 1.30 & 1.11 & 1.04 & 0.65 \\
\hline 13 & Public assembly & 1.40 & 1.21 & 1.03 & 0.97 & 0.60 \\
\hline 14 & Education & 1.80 & 1.21 & 1.03 & 0.97 & 0.60 \\
\hline 15 & Food service & 1.60 & 1.39 & 1.18 & 1.11 & 0.70 \\
\hline 16 & Health care (inpatient) & 1.70 & 1.21 & 1.03 & 0.97 & 0.60 \\
\hline 17 & Skilled nursing & 1.30 & 1.02 & 0.87 & 0.82 & 0.51 \\
\hline 18 & Lodging & 1.30 & 1.02 & 0.87 & 0.82 & 0.51 \\
\hline 23 & Strip shopping & 1.90 & 1.49 & 1.27 & 1.19 & 0.74 \\
\hline 26 & Service (excluding food) & 1.70 & 1.39 & 1.18 & 1.11 & 0.70 \\
\hline 91 & Other & 1.70 & 1.02 & 0.87 & 0.82 & 0.51 \\
\hline
\end{tabular}


Table 3-21 LPDs by PBA for Various Scenarios: SI Units

\begin{tabular}{|c|c|c|c|c|c|c|}
\hline $\begin{array}{l}\text { PBA } \\
\text { Code }\end{array}$ & PBA & $\begin{array}{c}\text { Existing } \\
\left(\mathrm{W} / \mathrm{m}^{2}\right)\end{array}$ & $\begin{array}{c}\text { Base } \\
\left(\mathrm{W} / \mathrm{m}^{2}\right)\end{array}$ & $\begin{array}{c}\text { Draft } \\
\text { Standard } \\
189 \mathrm{P}(-15 \%) \\
\left(\mathrm{W} / \mathrm{m}^{2}\right)\end{array}$ & $\begin{array}{c}\text { Max Tech } \\
20 \% \text { LPD } \\
(-20 \%) \\
\left(\mathrm{W} / \mathrm{m}^{2}\right) \\
\end{array}$ & $\begin{array}{c}\text { Max Tech } \\
\text { Root } \\
(-50 \%) \\
\left(\mathrm{W} / \mathrm{m}^{2}\right) \\
\end{array}$ \\
\hline 1 & Vacant & 22.6 & 11.0 & 9.3 & 8.8 & 5.5 \\
\hline 2 & Office/professional & 19.4 & 11.0 & 9.3 & 8.8 & 5.5 \\
\hline 4 & Laboratory & 18.3 & 15.0 & 12.7 & 12.0 & 7.5 \\
\hline 5 & Nonrefrigerated warehouse & 15.1 & 9.0 & 7.7 & 7.2 & 4.5 \\
\hline 6 & Food sales & 20.5 & 16.0 & 13.6 & 12.8 & 8.0 \\
\hline 7 & Public order/safety & 14.0 & 11.0 & 9.3 & 8.8 & 5.5 \\
\hline 8 & Health care (outpatient) & 18.3 & 11.0 & 9.3 & 8.8 & 5.5 \\
\hline 11 & Refrigerated warehouse & 15.1 & 9.0 & 7.7 & 7.2 & 4.5 \\
\hline 12 & Religious worship & 15.1 & 14.0 & 11.9 & 11.2 & 7.0 \\
\hline 13 & Public assembly & 15.1 & 13.0 & 11.1 & 10.4 & 6.5 \\
\hline 14 & Education & 19.4 & 13.0 & 11.1 & 10.4 & 6.5 \\
\hline 15 & Food service & 17.2 & 15.0 & 12.7 & 12.0 & 7.5 \\
\hline 16 & Health care (inpatient) & 18.3 & 13.0 & 11.1 & 10.4 & 6.5 \\
\hline 17 & Skilled nursing & 14.0 & 11.0 & 9.3 & 8.8 & 5.5 \\
\hline 18 & Lodging & 14.0 & 11.0 & 9.3 & 8.8 & 5.5 \\
\hline 23 & Strip shopping & 20.5 & 16.0 & 13.6 & 12.8 & 8.0 \\
\hline 26 & Service (excluding food) & 18.3 & 15.0 & 12.7 & 12.0 & 7.5 \\
\hline 91 & Other & 18.3 & 11.0 & 9.3 & 8.8 & 5.5 \\
\hline
\end{tabular}

Table 3-22 Daylighting Control Scheme

\begin{tabular}{|l|c|}
\hline \multicolumn{2}{|c|}{ Daylighting Controls } \\
\hline \hline No. sensors & 1 \\
\hline Position & center \\
\hline Fraction & 0.99 \\
\hline Set point & 400 lux \\
\hline Control & stepped \\
\hline No. steps & 3 \\
\hline Probable reset & 1.0 \\
\hline
\end{tabular}

\subsubsection{Plug and Process Loads}

Plug and process power density is used to model interior electrical equipment in watts per unit area combined with schedules. For the existing stock models, the plug and process power densities were determined by using a complex method intended to capture useful information in the CBECS data set and to target the energy end use results found in the California End Use Survey, or CEUS (CEC 2006). The methodology is described in Griffith et al. (2008). Each building in the set has a different baseline plug and process power density. The schedules are modeled from the schedule developed for each building's hours of operation and the CBECS variable for how equipment is turned off during off hours (see Griffith et al. 2008). Interior gas-powered appliances are also included in the models with input derived from CEUS to include cooking, miscellaneous, and process loads. Plug and process loads are held constant in 
the Max Tech scenario. AEO 2007 predicts plug and process energy intensity to increase so the assumption that these loads will hold steady is assuming that appliances and equipment will also improve in efficiency to offset the growth in use. The Max Tech High Appliance scenario (see below) assumes additional improvements in appliance and equipment efficiency to allow plug and process loads to decrease by $25 \%$.

\subsubsection{HVAC and Components}

Full descriptions of the heating, cooling, and outside air systems are used to model the HVAC systems that conditioned the building in EnergyPlus. The type of HVAC system used in the modeling is changed from what it was in the existing stock models (Griffith et al. 2008) to reflect the types of systems more commonly installed today and to apply Appendix G of 90.1-2004. Following the performance rating methodology of Appendix $G$ is desirable because this makes the baseline models more relevant to current rating programs such as the commercial tax credit and LEED ${ }^{\mathrm{TM}}$. In the existing stock models there are 52 system types; for the new construction models we reduce the number of system types to make it more practical to change the models to add such things economizers and air-to-air heat recovery systems on ventilation. Existing stock HVAC systems also include district heating and cooling, which we did not want to propagate to an assessment of ZEB opportunities because it moves services out of the building's control volume.

Table 3-23 lists the HVAC system types used in the modeling as determined in Table G3.1.1A of ASHRAE Standard 90.1-2004, Appendix G. These system types are applied to the baseline models to modify the existing stock models. Another difference between the existing stock models and the new construction models is that some buildings in the existing stock set are not conditioned at all and some are only heated or only cooled. In reality, many buildings are only partly heated or cooled, but when developing the existing stock models we made the simplifying assumption that buildings would be either entirely heated/cooled or not heated/cooled at all. We used a value of $25 \%$ of the part of the building that is conditioned as the criterion for determining how each model is conditioned (CBECS variables COOLP8 and HEATP8). However, in the current models based on Appendix G of 90.1-2004, all the buildings are served by complete HVAC systems with both heating and cooling. So in some cases, the new construction models are of buildings that provide a higher level of service in terms of thermal comfort. The system type assignments in Appendix G of 90.1-2004 depend on the availability of fossil fuel for heating; electric heating is the alternative. Whether or not heating is by electricity was determined from the CBECS data set using the value of the variable ELHT18.

The HVAC systems are controlled with dual thermostatic control based on dry bulb temperature in the zones. Zone thermostat set points are generally $70^{\circ} \mathrm{F}\left(21^{\circ} \mathrm{C}\right)$ for heating and $75^{\circ} \mathrm{F}\left(24^{\circ} \mathrm{C}\right)$ for cooling. Thermostat setup to $91^{\circ} \mathrm{F}\left(33^{\circ} \mathrm{C}\right)$ and setback to $55^{\circ} \mathrm{F}\left(13^{\circ} \mathrm{C}\right)$ are included in the models, depending on CBECS data for whether cooling or heating is reduced during a 24-hour period (2003 CBECS variables RDCLNF8 and RDHTNF8). Humidity is addressed indirectly by controlling supply air temperature. Set points for the supply air temperature in the baseline models are set by using a seasonal reset schedule with cold deck temperatures of $55^{\circ} \mathrm{F}\left(13^{\circ} \mathrm{C}\right)$ in the summer and $60^{\circ} \mathrm{F}\left(16^{\circ} \mathrm{C}\right)$ in the winter. In the Max Tech models this is changed to a dynamic scheme that resets based on outside air conditions.

The overall performance of the HVAC systems is modeled in EnergyPlus from the individual components that make up the system. In reality, HVAC systems often have control and mismatch problems that cannot be modeled directly in EnergyPlus. Therefore, the performance characteristics of primary components are intentionally degraded somewhat in an attempt to model system-level inefficiencies. Improved performance levels for these components are used for the Max Tech scenarios. Table 3-24 lists the coefficient of performance (COP) values for direct expansion (DX) cooling coils. These COPs include condenser fans but not supply fans. Table 3-25 lists the COP values for central water chillers (these do not include heat rejection). 
Table 3-26 lists the efficiency values for central water boilers. Table 3-27 lists the efficiency values for gas heating coils. Table 3-28 lists the COP values for air-to-air heat pumps. These COP values were used for EnergyPlus input and correspond to nominal values for the rated point of operation; see EnergyPlus input documentation for more detail.

Table 3-23 HVAC System Types

\begin{tabular}{|l|l|l|l|}
\hline \multicolumn{1}{|c|}{ System } & \multicolumn{1}{|c|}{ Building Type } & Heating Fuel & \multicolumn{1}{|c|}{$\begin{array}{c}\text { Primary HVAC } \\
\text { Components }\end{array}$} \\
\hline \hline 1. PTAC & Lodging & $\begin{array}{l}\text { Natural gas or } \\
\text { fuel oil }\end{array}$ & $\begin{array}{l}\text { Zone DX coils, central } \\
\text { boiler }\end{array}$ \\
\hline 2. PTHP & Lodging & Electricity & Zone heat pump \\
\hline 3. PSZ-AC & $\begin{array}{l}3 \text { floors or fewer and } \\
<75,000 \mathrm{ft}^{2}\end{array}$ & Natural gas & $\begin{array}{l}\text { Unitary DX coils, gas- } \\
\text { fired coil }\end{array}$ \\
\hline 4. PSZ-HP & $\begin{array}{l}3 \text { floors or fewer and } \\
<75,000 \mathrm{ft}^{2}\end{array}$ & Electricity & Unitary heat pump \\
\hline $\begin{array}{l}\text { 5. Packaged VAV } \\
\text { w/reheat }\end{array}$ & $\begin{array}{l}4 \text { or } 5 \mathrm{floors}^{2} \text { and } \\
<75,000 \mathrm{ft}^{2} \\
\text { or } 5 \mathrm{floors}^{2} \text { or fewer and } \\
75,000 \mathrm{ft}^{2} \text { to } 150,000 \mathrm{ft}^{2}\end{array}$ & $\begin{array}{l}\text { Natural gas or } \\
\text { fuel oil }\end{array}$ & $\begin{array}{l}\text { Central DX coil, central } \\
\text { boiler }\end{array}$ \\
\hline $\begin{array}{l}\text { 6. Packaged VAV } \\
\text { w/PFP boxes }\end{array}$ & $\begin{array}{l}75,000 \mathrm{ft}^{2} \\
\text { or } 5 \mathrm{floors}^{2} \text { or fewer and } \\
75,000 \mathrm{ft}^{2} \text { to } 150,000 \mathrm{ft}^{2}\end{array}$ & Electricity & $\begin{array}{l}\text { Central DX coil, parallel } \\
\text { fan power boxes with } \\
\text { electric reheat }\end{array}$ \\
\hline 7. VAV w/reheat & $\begin{array}{l}\text { More than } 5 \mathrm{floors}^{2} \text { or } \\
>150,000 \mathrm{ft}^{2}\end{array}$ & $\begin{array}{l}\text { Natural gas or } \\
\text { fuel oil }\end{array}$ & $\begin{array}{l}\text { Central chiller, cooling } \\
\text { towers, central boiler, }\end{array}$ \\
\hline $\begin{array}{l}\text { 8. VAV w/PFP boxes } \\
\text { More than } 5 \mathrm{floors}^{2} \text { or } \\
>150,000 \mathrm{ft}^{2}\end{array}$ & Electricity & $\begin{array}{l}\text { Central chiller, cooling } \\
\text { towers, parallel fan } \\
\text { power boxes with } \\
\text { electric reheat }\end{array}$ \\
\hline
\end{tabular}

Table 3-24 DX Coil COP Values

\begin{tabular}{|l|c|c|c|}
\hline \multicolumn{1}{|c|}{ Cooling Capacity } & Baseline & Standard 189P & Max Tech + 30\% \\
\hline \hline Small $(<65 \mathrm{kBtu})$ & 3.74 & 4.36 & 4.57 \\
\hline Medium $(>65 \mathrm{kBtu} ;<135 \mathrm{kBtu})$ & 2.90 & 3.31 & 3.77 \\
\hline Large $(>135 \mathrm{kBtu} ;<240 \mathrm{kBtu})$ & 2.67 & 3.31 & 3.47 \\
\hline Very large $(>240 \mathrm{kBtu})$ & 2.58 & 2.87 & 3.35 \\
\hline
\end{tabular}

Table 3-25 Central Chiller COP values

\begin{tabular}{|l|c|c|c|}
\hline \multicolumn{1}{|c|}{ Cooling Capacity } & Baseline & Standard 189P & Max Tech $+\mathbf{3 0 \%}$ \\
\hline \hline Very small $(<75$ tons) & 4.45 & 4.51 & 5.79 \\
\hline Small (<150 tons) & 4.45 & 4.82 & 5.79 \\
\hline Medium (> 150 tons; $<300$ tons) & 4.90 & 5.77 & 6.37 \\
\hline Large (> 300 tons) & 5.5 & 5.86 & 7.15 \\
\hline
\end{tabular}


Table 3-26 Boiler Combustion Efficiency Values

\begin{tabular}{|c|c|}
\hline Baseline & Max Tech \\
\hline 0.80 & 0.96 \\
\hline
\end{tabular}

Table 3-27 Natural Gas Heating Coil Combustion Efficiency Values

\begin{tabular}{|c|c|}
\hline Baseline & Max Tech \\
\hline 0.80 & 0.90 \\
\hline
\end{tabular}

Table 3-28 Heat Pump COP Values

\begin{tabular}{|l|c|c|c|}
\hline \multicolumn{1}{|c|}{ Heating Capacity } & Baseline & Standard 189P & Max Tech + 30\% \\
\hline \hline Small $(<65 \mathrm{kBtu})$ & 3.4 & 3.4 & 4.42 \\
\hline Medium $(>65 \mathrm{kBtu} ;<135 \mathrm{kBtu})$ & 3.2 & 3.2 & 4.16 \\
\hline Large $(>135 \mathrm{kBtu} ;<240 \mathrm{kBtu})$ & 3.1 & 3.1 & 4.03 \\
\hline Very large $(>240 \mathrm{kBtu})$ & 3.0 & 3.0 & 3.90 \\
\hline
\end{tabular}

Thermal distribution systems transport air or water to condition the building. Total efficiency and static pressures are used to model the energy used by fans and pumps. Thermal losses and leaks in the distribution system are important real-world concerns, but were not included in the modeling because EnergyPlus does not support such modeling well enough and a no-loss distribution seems appropriate for maximum technology scenarios. Table 3-29 lists the fan total efficiencies for packaged systems; these values may be overly optimistic and lead to under-predicting the energy use for fans. Table 3-30 lists the fan static pressure values for packaged systems.

Table 3-31 lists the fan static pressure values for through-the-wall PTAC and PTHP systems. Table 3-32 lists the total fan efficiency values for central air systems with variable volume flow. Table 3-33 lists the fan static pressure values for central air systems with variable volume flow. Table 3-34 lists the motor efficiency values for water pumps in hydronic systems; these values may be overly optimistic for smaller pumps and lead to underpredicting the energy use of pumps. Table 3-35 lists the pump head values for hydronic systems; these are crude defaults from large pumping systems. These values are what were used for EnergyPlus input; see EnergyPlus input documentation for more detail.

Table 3-29 Packaged System Constant Volume Fan Total Efficiency Values

\begin{tabular}{|c|c|}
\hline Baseline & Max Tech \\
\hline \hline 0.60 & 0.70 \\
\hline
\end{tabular}

Table 3-30 Packaged System Fan Static Pressure Values

\begin{tabular}{|c|c|c|}
\hline Units & Baseline & Max Tech -20\% \\
\hline \hline in. $\mathrm{H}_{2} \mathrm{O}$ & 2.0 & 1.6 \\
\hline $\mathrm{Pa}$ & 500 & 400 \\
\hline
\end{tabular}


Table 3-31 PTAC and PTHP Fan Static Pressure Values

\begin{tabular}{|c|c|c|}
\hline Units & Baseline & Max Tech - 20\% \\
\hline \hline in. $\mathrm{H}_{2} \mathrm{O}$ & 1.2 & 1.0 \\
\hline $\mathrm{Pa}$ & 300 & 240 \\
\hline
\end{tabular}

Table 3-32 Central System Variable Volume Fan Total Efficiency Values

\begin{tabular}{|c|c|}
\hline Baseline & Max Tech \\
\hline \hline 0.65 & 0.70 \\
\hline
\end{tabular}

Table 3-33 Central System Fan Static Pressure Values

\begin{tabular}{|c|c|c|}
\hline Units & Baseline & Max Tech $-\mathbf{1 7 \%}$ \\
\hline in. $\mathrm{H}_{2} \mathrm{O}$ & 2.4 & 2.0 \\
\hline $\mathrm{Pa}$ & 600 & 498 \\
\hline
\end{tabular}

Table 3-34 Hydronic System Pump Efficiency Values

\begin{tabular}{|c|c|}
\hline Baseline & Max Tech \\
\hline \hline 0.90 & 0.95 \\
\hline
\end{tabular}

Table 3-35 Hydronic System Pump Head Pressure Values

\begin{tabular}{|c|c|c|}
\hline Units & Baseline & Max Tech - 17\% \\
\hline in. $\mathrm{H}_{2} \mathrm{O}$ & 720 & 598 \\
\hline $\mathrm{Pa}$ & 179,352 & 148,862 \\
\hline
\end{tabular}

HVAC systems for the Max Tech scenarios also add additional low-energy components that are not necessarily found in the baseline systems. These include motorized outside air dampers, and heat recovery ventilation (HRV) systems. Motorized dampers are already present in many of the baseline models (per 90.1-2004). For the Max Tech scenarios, the outside air systems all include motorized dampers and HRVs. HRVs are bypassed during economizer operation using a mix of dry bulb temperature (outside air between $36^{\circ} \mathrm{F}$ and $66^{\circ} \mathrm{F}\left(2^{\circ} \mathrm{C}\right.$ and $\left.19^{\circ} \mathrm{C}\right)$, and enthalpy limits (outside air less than $14 \mathrm{Btu} / \mathrm{lb}[32 \mathrm{~kJ} / \mathrm{kg}])$. The outside air systems with HRVs are assumed to be sized for just the minimum outside air requirements and do not provide extra flow for economizing. Table 3-36 lists values for heat exchanger effectiveness used to model HRVs; these values may be pessimistic and could cause air system energy use in Max Tech scenarios to be overpredicted. Motorized outside air dampers are modeled by changing the minimum outside air rates to be zero when unoccupied.

Table 3-36 Ventilation Energy Recovery Percent Effectiveness Values

\begin{tabular}{|l|c|c|c|}
\hline \multicolumn{1}{|c|}{ Heat Type } & Baseline & Standard 189P & Max Tech \\
\hline \hline Sensible & 50 & 60 & 70 \\
\hline Latent & 50 & 60 & 62 \\
\hline
\end{tabular}

\subsubsection{Refrigeration}

Refrigeration systems are currently modeled by using a simple power density with a continuous run schedule. The refrigeration energy is modeled as exterior electrical equipment that does not affect loads met by the HVAC system. EnergyPlus offers more detailed modeling capabilities, but these are not being 
used in the study. Resources did not permit developing methods of fully describing refrigeration systems for more detailed modeling across all types of commercial buildings using the scant data in 2003 CBECS. Table 3-37 and Table 3-38 list the power densities for refrigeration used the study. The baseline refrigeration power densities are the same as the existing stock models and were derived from CEUS (CEC 2006) with assumptions for subsectors that are not covered by CEUS.

Table 3-37 Refrigeration Power Densities by Subsector: IP Units

\begin{tabular}{|c|c|c|}
\hline $\begin{array}{l}\text { Subsector } \\
\text { (PBA) }\end{array}$ & $\begin{array}{c}\text { Baseline } \\
\left(\mathrm{W} / \mathrm{ft}^{2}\right)\end{array}$ & $\begin{array}{c}\text { Max Tech }-30 \% \\
\left(\mathbf{W} / \mathrm{ft}^{2}\right)\end{array}$ \\
\hline "Office/professional $<30,000 \mathrm{ft}^{2}$ & 0.074 & 0.052 \\
\hline Office/professional $>30,000 \mathrm{ft}^{2}$ & 0.056 & 0.039 \\
\hline Nonrefrigerated warehouse & 0.046 & 0.033 \\
\hline Education & 0.056 & 0.039 \\
\hline Retail (excluding mall) & 0.149 & 0.104 \\
\hline Public assembly & 0.028 & 0.020 \\
\hline Service & 0.121 & 0.085 \\
\hline Religious worship & 0.028 & 0.020 \\
\hline Lodging & 0.139 & 0.098 \\
\hline Food services & 1.124 & 0.787 \\
\hline Health care (inpatient) & 0.084 & 0.059 \\
\hline Public order and safety & 0.056 & 0.039 \\
\hline Food sales & 2.601 & 1.821 \\
\hline Health care (outpatient) & 0.084 & 0.059 \\
\hline Vacant & 0.000 & 0.000 \\
\hline Other & 0.102 & 0.072 \\
\hline Skilled nursing & 0.084 & 0.059 \\
\hline Laboratory & 0.279 & 0.195 \\
\hline Refrigerated warehouse & 1.533 & 1.073 \\
\hline
\end{tabular}

\subsubsection{Photovoltaic On-Site Generation}

The Max Tech scenario includes on-site energy production with rooftop PV power systems. The basic assumption for sizing the PV system in the Max Tech scenarios is that the active area is equal to 50\% of the total roof area for each building. This sizing method was selected as a reasonable balance; some buildings with flat roofs and no rooftop equipment could have more than 50\%; others will have pitched roofs or rooftop equipment that would not allow 50\%. This sizing method leads to some net producing buildings. For the Standard 189P scenario, PV systems are sized to 2\% of the building's service load. The model for PV production, called "Simple" in EnergyPlus, uses a fixed efficiency for solar to DC conversion and another fixed efficiency for DC to AC conversion. The model does not account for the complex effects of incidence angle and temperature on performance. The PV modules are mounted flat on the flat roof. Although EnergyPlus offers better models for PV production, the simple model was selected because empirical input data needed for the more detailed models cannot be obtained for future PV systems because they are not yet available for testing.

Table 3-39 lists the performance levels for the PV systems for the different scenarios. The Max Tech performance projections were chosen to be generally consistent with stated goals of the DOE Solar Program. For example, the Photovoltaic Program Plan for 2000-2004 lists goals for module efficiencies at $10 \%$ to $20 \%$ by 2005 and $15 \%-25 \%$ by 2020 to 2030 (NREL 2000). The FY 2004 annual report for the National Center for Photovoltaics lists goals for the High Performance Photovoltaics Project as 
"developing thin-film tandem cells and modules toward 25\% and 20\% efficiencies, respectively" (DOE 2005a). That report also lists goals for the Inverter and balance of systems Development Project with inverter efficiency greater than $94 \%$, so we assumed inverter efficiencies of $95 \%$ for the Max Tech scenario. There is no electrical storage, and any excess production is fed directly into the grid. The analysis here is confined to the buildings and includes an implicit (and largely erroneous) assumption that the electrical grid could handle very large amounts of distributed solar electric power. Currently available crystalline PV products already reach $20 \%$ efficiency; the scenario analyzed here is one where low-cost, amorphous PV products with $20 \%$ are widespread.

\begin{tabular}{|c|c|c|}
\hline \multicolumn{3}{|c|}{ Refrigeration Power Densities by Subsector: SI units } \\
\hline $\begin{array}{l}\text { Subsector } \\
\text { (PBA) }\end{array}$ & $\begin{array}{c}\text { Baseline } \\
\left(W / m^{2}\right)\end{array}$ & $\begin{array}{c}\text { Max Tech }-30 \% \\
\left(\mathrm{~W} / \mathrm{m}^{2}\right)\end{array}$ \\
\hline Office/professional $<30,000 \mathrm{ft}^{2}$ & 0.8 & 0.56 \\
\hline Office/professional > 30,000 $\mathrm{ft}^{2}$ & 0.6 & 0.42 \\
\hline Nonrefrigerated warehouse & 0.5 & 0.35 \\
\hline Education & 0.6 & 0.42 \\
\hline Retail (excluding mall) & 1.6 & 1.12 \\
\hline Public assembly & 0.3 & 0.21 \\
\hline Service & 1.3 & 0.91 \\
\hline Religious worship & 0.3 & 0.21 \\
\hline Lodging & 1.5 & 1.05 \\
\hline Food services & 12.1 & 8.47 \\
\hline Health care (inpatient) & 0.9 & 0.63 \\
\hline Public order and safety & 0.6 & 0.42 \\
\hline Food sales & 28.0 & 19.6 \\
\hline Health care (outpatient) & 0.9 & 0.63 \\
\hline Vacant & 0.0 & 0.0 \\
\hline Other & 1.1 & 0.77 \\
\hline Skilled nursing & 0.9 & 0.63 \\
\hline Laboratory & 3.0 & 2.1 \\
\hline Refrigerated warehouse & 16.5 & 11.55 \\
\hline
\end{tabular}

Table 3-39 Solar Electric System Performance Levels

\begin{tabular}{|l|c|c|}
\hline & Standard 189P & Max Tech \\
\hline \hline Sizing method & $2 \%$ of service load & $50 \%$ of roof area \\
\hline PV module efficiency (\%) & 10 & 20 \\
\hline Solar electric inverter efficiency (\%) & 92 & 95 \\
\hline
\end{tabular}

\subsection{Investigating Individual Technologies and Practices}

A number of alternate modeling scenarios were developed to help explore the relative potential for individual technologies and practices to contribute to meeting the ZEB goal. Table 3-40 summarizes the alternate modeling scenarios included in the study's methods and described in this section.

Energy design measures are either added or subtracted to a basis scenario to create an alternate scenario. A "subtraction" scenario perturbs a scenario by changing to a poorer performing alternate, while an "addition" scenario changes to a better performing alternate. A given technology or practice can be evaluated by comparing the results of alternate scenarios to the basis scenario where the only differences involve that technology or practice. Analysis in the "ZEB context" uses the Max Tech scenario as the basis; the "current context" uses the Base scenario as the basis. 
Table 3-40 Summary of Scenarios Examined

\begin{tabular}{|c|c|c|c|}
\hline Scenario Name & $\begin{array}{l}\text { Intended } \\
\text { Focus }\end{array}$ & Notes on How Developed & $\begin{array}{c}\text { Type of } \\
\text { Perturbation }\end{array}$ \\
\hline Base & \multirow{2}{*}{$\begin{array}{l}\text { Overall ZEB } \\
\text { Goal }\end{array}$} & Apply Standard 90.1-2004 to Existing Stock models & (basis) \\
\hline Max Tech & & $\begin{array}{l}\text { Apply broad package of aggressive ZEB technologies and } \\
\text { practices projected for year } 2025\end{array}$ & (basis) \\
\hline Base w PV & $\begin{array}{l}\text { Efficiency for } \\
\text { ZEB goal }\end{array}$ & $\begin{array}{l}\text { Apply PV systems to Base; same PV system as used in Max } \\
\text { Tech. }\end{array}$ & Addition \\
\hline Base $20 \%$ LPD & \multirow{4}{*}{$\begin{array}{l}\text { Lighting } \\
\text { Equipment }\end{array}$} & $\begin{array}{l}\text { Apply improved lighting performance to Base; LPDs reduced by } \\
20 \% \text { from Base. }\end{array}$ & Addition \\
\hline Base $50 \%$ LPD & & $\begin{array}{l}\text { Apply improved lighting performance to Base; LPDs reduced by } \\
50 \% \text { from Base. }\end{array}$ & Addition \\
\hline Max Tech Base LPD & & $\begin{array}{l}\text { Apply reduced lighting performance to Max Tech; LPDs same as } \\
\text { Base; LPDs } 100 \% \text { higher than Max Tech }\end{array}$ & Subtraction \\
\hline $\begin{array}{l}\text { Max Tech with } 20 \% \\
\text { LPD }\end{array}$ & & $\begin{array}{l}\text { Apply reduced lighting performance to Max Tech; LPDs } 20 \% \\
\text { lower than Base; LPDs } 60 \% \text { higher than Max Tech. }\end{array}$ & Subtraction \\
\hline $\begin{array}{l}\text { Base Side } \\
\text { Daylighting }\end{array}$ & \multirow{4}{*}{ Daylighting } & Apply daylighting controls to Base. & Addition \\
\hline $\begin{array}{l}\text { Base Top and Side } \\
\text { Daylighting }\end{array}$ & & $\begin{array}{l}\text { Apply rooftop fenestration (TDDs) and daylighting controls to } \\
\text { Base }\end{array}$ & Addition \\
\hline $\begin{array}{l}\text { Max Tech No } \\
\text { Daylighting }\end{array}$ & & Remove daylighting controls from Max Tech. & Subtraction \\
\hline $\begin{array}{l}\text { Max Tech Side } \\
\text { Daylighting }\end{array}$ & & Remove rooftop fenestration (TDDs) from Max Tech. & Subtraction \\
\hline $\begin{array}{l}\text { Base Dynamic } \\
\text { Windows }\end{array}$ & \multirow{2}{*}{$\begin{array}{l}\text { Dynamic } \\
\text { Windows }\end{array}$} & Apply dynamic windows to Base. & Addition \\
\hline $\begin{array}{l}\text { Max Tech Base } \\
\text { Windows }\end{array}$ & & Remove dynamic windows from Max Tech; use Base windows. & Subtraction \\
\hline Base High Envelope & \multirow{2}{*}{ Insulation } & $\begin{array}{l}\text { Apply high-performance opaque envelope } \\
\text { (defined by draft Standard 189P) to Base }\end{array}$ & Addition \\
\hline $\begin{array}{l}\text { Max Tech Base } \\
\text { Envelope }\end{array}$ & & $\begin{array}{l}\text { Remove high-performance opaque envelope from Max Tech; Use } \\
\text { Base opaque envelope. }\end{array}$ & Subtraction \\
\hline Base High HVAC & \multirow[b]{2}{*}{ HVAC } & Apply high levels of HVAC component performance to Base. & Addition \\
\hline $\begin{array}{l}\text { Max Tech Base } \\
\text { HVAC }\end{array}$ & & $\begin{array}{l}\text { Remove high levels of HVAC component performance from Max } \\
\text { Tech. }\end{array}$ & Subtraction \\
\hline Base Passive Solar & \multirow{2}{*}{$\begin{array}{l}\text { Architectural } \\
\text { Form }\end{array}$} & $\begin{array}{l}\text { Apply daylighting controls and form changes for passive solar } \\
\text { (overhangs, fins, east west elongation, and alignment) to Base }\end{array}$ & Addition \\
\hline $\begin{array}{l}\text { Max Tech Passive } \\
\text { Solar }\end{array}$ & & $\begin{array}{l}\text { Apply form changes for passive solar to Max Tech; overhangs, } \\
\text { fins, east west elongation, and alignment }\end{array}$ & Addition \\
\hline Base High Appliance & \multirow{2}{*}{$\begin{array}{l}\text { Plug and } \\
\text { Process } \\
\text { Loads }\end{array}$} & $\begin{array}{l}\text { Apply improved appliances to Base by reducing power densities } \\
\text { for internal electrical and gas loads by } 25 \%\end{array}$ & Addition \\
\hline $\begin{array}{l}\text { Max Tech High } \\
\text { Appliance }\end{array}$ & & $\begin{array}{l}\text { Apply improved appliances to Max Tech by reducing power } \\
\text { densities for internal electrical and gas loads by } 25 \%\end{array}$ & Addition \\
\hline Standard 90.1-1999 & \multirow{2}{*}{ Standards } & Apply Standard 90.1-1999 to Existing Stock models & (Subtraction) \\
\hline Standard 189P & & Apply draft Standard 189P to Base & (Addition) \\
\hline
\end{tabular}

\subsubsection{Efficiency}

Although it is generally understood that energy efficiency needs to be included in efforts to meet the ZEB goal, the issue is assessed quantitatively by including the following scenario:

Base with PV is an addition perturbation of the Base scenario where PV systems used in the Max Tech scenario (see below) are added. 
By comparing the results from the Base with PV scenario to those of the Max Tech scenario, we can characterize the relative importance of efficiency in meeting the ZEB goal.

\subsubsection{Lighting}

Lighting technologies are important to the energy performance of commercial buildings. DOE currently supports the development of solid-state lighting systems. More efficient lighting equipment is modeled by reducing the LPD. The following four alternate scenarios were included to investigate the relative impact of lighting equipment on commercial building energy performance:

- Base 20\% LPD is an addition perturbation of the Base scenario where improved lighting equipment is added. LPD values are applied at the level 20\% lower than Standard 90.1-2004. There is no daylighting.

- Base 50\% LPD is an additive perturbation of the Base scenario where improved lighting equipment is added. LPD values are applied at the same level of Max Tech scenario, which is reduced 50\% from Standard 90.1-2004. There is no daylighting.

- Max Tech 20\% LPD is a subtractive perturbation of the Max Tech scenario where the LPD is set to $20 \%$ lower than the levels prescribed by Standard 90.1-2004 (rather than the 50\% lower levels in the Max Tech scenario). There is daylighting.

- Max Tech Base Lighting is a perturbation of the Max Tech scenario where the LPD is set to the levels prescribed by Standard 90.1-2004 (rather than the 50\% lower levels in the Max Tech scenario). There is daylighting.

These alternate scenarios can be compared to the basis scenarios and to each other to analyze the overall impacts of improved lighting equipment. LPD values are listed in Table 3-20 and Table 3-21.

\subsubsection{Daylighting}

Daylighting is an important way of reducing the energy consumed by electric lighting equipment in commercial buildings. The following four scenarios were included to investigate the relative impact of daylighting on commercial building energy performance:

- Base Side Daylighting is an addition perturbation of the Base scenario where daylighting controls have been added to each zone.

- Base Top and Side Daylighting is an addition perturbation of the Base scenario where rooftop fenestration has been added to the top floor core zone and daylighting controls have been added to each zone.

- Max Tech No Daylighting is a subtraction perturbation of the Max Tech scenario where daylighting controls and rooftop fenestration are removed from the building.

- Max Tech Side Daylighting is a subtraction perturbation of the Max Tech scenario where rooftop fenestration is removed from the building.

These alternate scenarios can be compared to the basis scenarios and to each other to analyze the overall impacts of daylight harvesting.

The architectural changes for "top lit" daylighting designs include the addition of TDDs to the roof over core zones. Thermal zones on the perimeter are assumed to be daylit from the side by the usual vertical windows for vision (the modeling does not add side fenestration for daylighting). TDDs are added to illuminate the core zone of the top floor. All of the Max Tech scenarios include TDDs. The Base Side Daylighting scenario does not include TDDs. 


\subsubsection{Dynamic Windows}

Dynamic windows are a relatively new technology for improving the energy performance of commercial buildings. DOE currently supports the development of dynamic windows. The following two alternate scenarios were included to investigate the relative impact of dynamic windows on commercial building energy performance:

- Base Dynamic Windows is an addition perturbation where dynamic windows are applied to the Base scenario.

- Max Tech Base Windows is a subtraction perturbation of the Max Tech scenario where dynamic windows are removed and the windows are the same as the Base scenario.

These alternate scenarios can be compared to the basis scenarios to analyze the overall potential for dynamic windows. The properties of the dynamic windows are listed in Table 3-18.

\subsubsection{Insulation}

Thermal insulation has long been an obvious method of improving building energy performance. The following two scenarios were included to investigate the potential for additional improvement to the thermal performance of opaque exterior envelopes:

- Base High Envelope is an addition perturbation of the Base scenario where the opaque insulation is set at the levels prescribed by a draft version of Standard 189P.

- Max Tech Base Envelope is a subtraction perturbation of the Max Tech scenario where the envelope descriptions are set to the baseline levels defined by Standard 90.1-2004.

These alternate scenarios can be compared to the basis scenarios to analyze the overall potential for opaque insulation. U-factors for insulation levels are listed in Table 3-1 through Table 3-7.

\subsubsection{HVAC}

Increasing the efficiency of HVAC components has long been an obvious method of improving building energy performance. The following two scenarios were included to investigate the potential for improved HVAC components:

- Base High HVAC is an addition perturbation of the Base scenario where the HVAC systems used in the Max Tech scenario are applied.

- Max Tech Base HVAC is a perturbation of the Max Tech scenario where the HVAC systems are left unchanged from those used in the Base scenario.

These alternate scenarios can be compared to the basis scenarios to analyze the overall potential for improving HVAC component efficiencies. The HVAC systems and component efficiencies for the Max Tech scenario are discussed in Section 3.2.4.

\subsubsection{Architectural Form}

Architectural form is a potentially powerful design measure for low-energy buildings. Many people consider the shape, or form, of a building to be fixed and not available for consideration in low-energy buildings; others advocate low-energy design practices that alter form in a climate-sensitive way and consider that architectural design is an important "technology" for reaching the ZEB goal. For buildings in urban areas, the size and shape of the site often dictate the design of the building. This study quantifies the technical potential in a preliminary way by applying a set of well-known rules of thumb that involve design principles such as east-west alignment, elongated aspect ratios, fixed overhangs on south glazings, and side fins on east and west glazings. The following two alternate scenarios explore the relative impact that architecture can have on energy performance: 
- Base Passive Solar is an addition perturbation of the Base scenario where the overall geometry is changed to apply passive solar design strategies and daylighting controls have been added to each zone.

- Max Tech Passive Solar is an addition perturbation of the Max Tech scenario where the overall geometry is changed to apply passive solar design strategies.

For these "Passive Solar" scenarios, we assume that some form parameters can be altered to (potentially) improve energy performance while the building's total floor area and number of floors remain fixed. The form changes that were made for the Passive Solar scenarios include:

- Add daylighting controls to dim electric lights. This is intended to reduce electric lights by using natural lighting.

- Orient all buildings along an east-west axis by assigning a rotation (azimuth) of zero.

- Elongate all buildings in the east-west direction by increasing the aspect ratio by a factor of 2 up to a limit of aspect ratio 10 . This is intended to avert cooling loads by reducing east and west exposures and increasing exposure along the south, which can be more easily controlled with overhangs. Elongating the building indirectly increases infiltration rates because of the additional wall area.

- For buildings with a south glazing area fraction less than 0.5 , increase the south glazing area by a factor of 2 up to a limit of an area fraction of 0.5. This is intended to increase solar gains for passive heating (but may hurt performance in cooling-dominated buildings).

- For buildings with an east glazing area fraction greater than 0.1 , decrease the east glazing area by a factor of 2 down to a limit of an area fraction of 0.1 . This is intended to decrease solar gains to avert cooling.

- For buildings with a west glazing area fraction greater than 0.1 , decrease the west glazing area by a factor of 2 down to a limit of an area fraction of 0.1. This is intended to decrease solar gains to avert cooling.

- Apply fixed, external overhangs to protect south-facing glazing with projection factors varied by location per the design guidance in the NREL Solar Radiation Data Manual for Buildings (referred to as the Blue Book; Marion and Wilcox 1995). The overhang designs in the Blue Book are intended to strike a balance between averting cooling loads and admitting solar heat during the heating season.

- For buildings with an east glazing fraction of at least 0.1 , apply overhangs and fins with a projection factor that is twice the Blue Book value. This is intended to decrease solar gains to avert cooling.

- For buildings with a west glazing fraction of at least 0.1 , apply overhangs and fins with a projection factor that is twice the Blue Book value. This is intended to decrease solar gains to avert cooling.

Figure 3-2 shows an example of how these form changes affected one building. These changes are based on expert opinion to provide more south-facing vertical fenestration for improved passive solar performance and more perimeter space for daylighting in multistory buildings. These form changes are used to model the potential for passive solar and would not be practical for all commercial buildings because of real-world land constraints imposed by individual sites. Thermal mass was not increased in the passive solar models and could lead to underestimating the impacts of these measures.

For all the other scenarios, the geometry of each building is kept the same as what was generated for the existing stock models. Those are documented by Griffith et al. (2008), but are based on a number of 
CBECS variables; the rest of the needed detail is generated synthetically. The random assignments used to fill out values for geometry parameters produce a widely varying set of buildings with all sorts of sizes, shapes, orientations, and glazed areas. However, the floor plates are all highly simplified rectangles and use generic five-zone-per-floor thermal blocks with uniform internal loading.

\subsubsection{Plug and Process Loads}

Plug and process loads include a wide variety of occupant-driven energy uses. The energy used by electricity- and gas-powered equipment that is not related to HVAC and lighting (non-HVAC\&L) has long been considered separate from building design. Plug and process loads are considered "unregulated" in the context of building energy standards. However, plug and process loads are expected to be important in the context of the whole-building energy performance and the ZEB goal. The technical potential for ZEB might be affected by improvements in the efficiency of appliances and devices (computers, copiers, cash registers, refrigeration, elevators, etc.) that use electricity or gas inside commercial buildings. Such improvements might be facilitated by BT's future activities in regulatory activities, appliance and emerging technologies, or Energy Star ${ }^{\circledR}$. The following two scenarios were included to investigate the relative impacts of plug and process loads on commercial building energy performance:

- Base High Appliance is an addition perturbation of the Base scenario where the plug and process electrical and gas power densities are set to be $25 \%$ lower.

- Max Tech High Appliance is an addition perturbation of the Max Tech scenario where the plug and process electrical and gas power densities are set to be $25 \%$ lower.

The percent savings in such electricity end uses was chosen by assumption because these devices are not currently covered in these program areas and pertinent strategic goals have not been developed.

\subsubsection{Industry-Developed Standards}

Industry associations such as ASHRAE have long been developing standards for energy-related aspects of new construction. Industry standards such as 90.1 are often referenced by state and local building codes, but are developed voluntarily by standing committees who use a consensus process and public review and comment resolution. We used 90.1-2004 to define the Base scenario in this study. The following two alternate scenarios are included to explore the relative stringency of selected standards:

- Standard 90.1-1999 is a scenario where the prescriptive measures of Standard 90.1-1999 have been applied to the Existing Stock models (ASHRAE 1999).

- Standard 189P is a scenario where the prescriptive measures in the first public draft version of Standard 189P have been applied to the Base scenario. The goal set for energy performance in Standard 189P is to achieve a 30\% improvement over Standard 90.1-2007. Specific performance values used in the modeling for Standard 189P were documented in various tables in Section 3.2. The scenario includes skylights that cover $3 \%$ of the floor area for most types of buildings. 


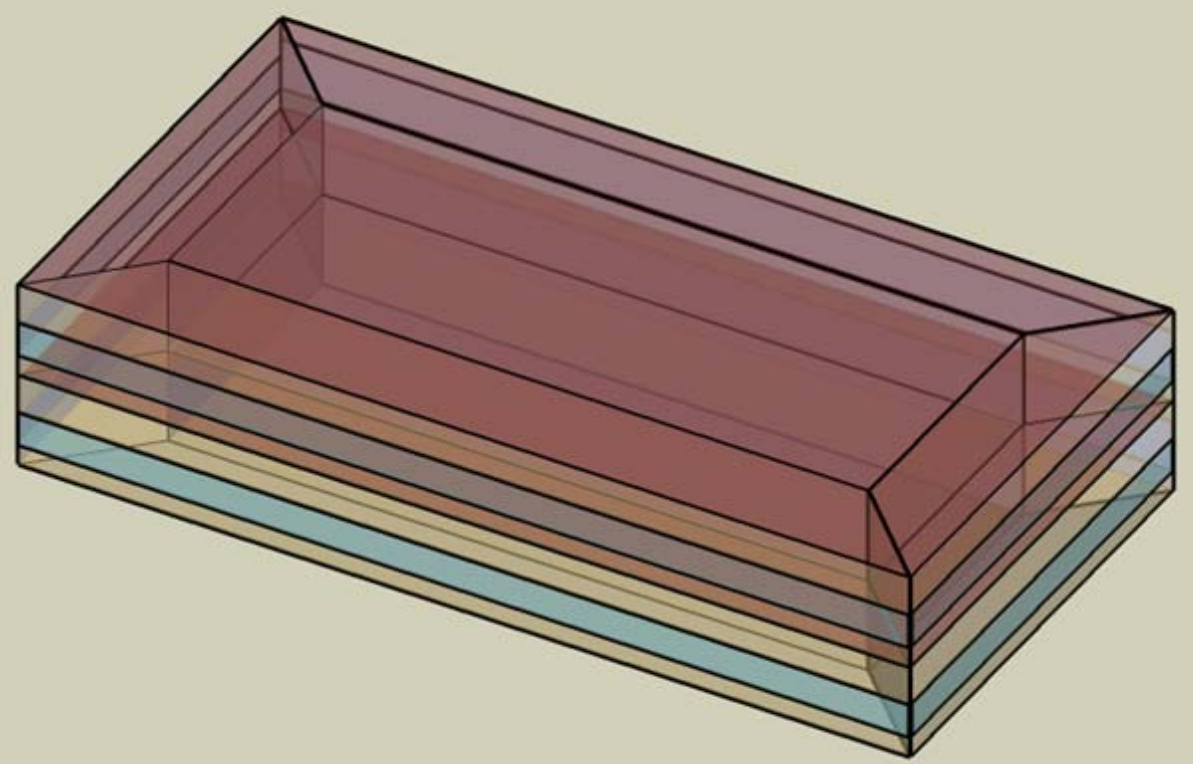

(a)

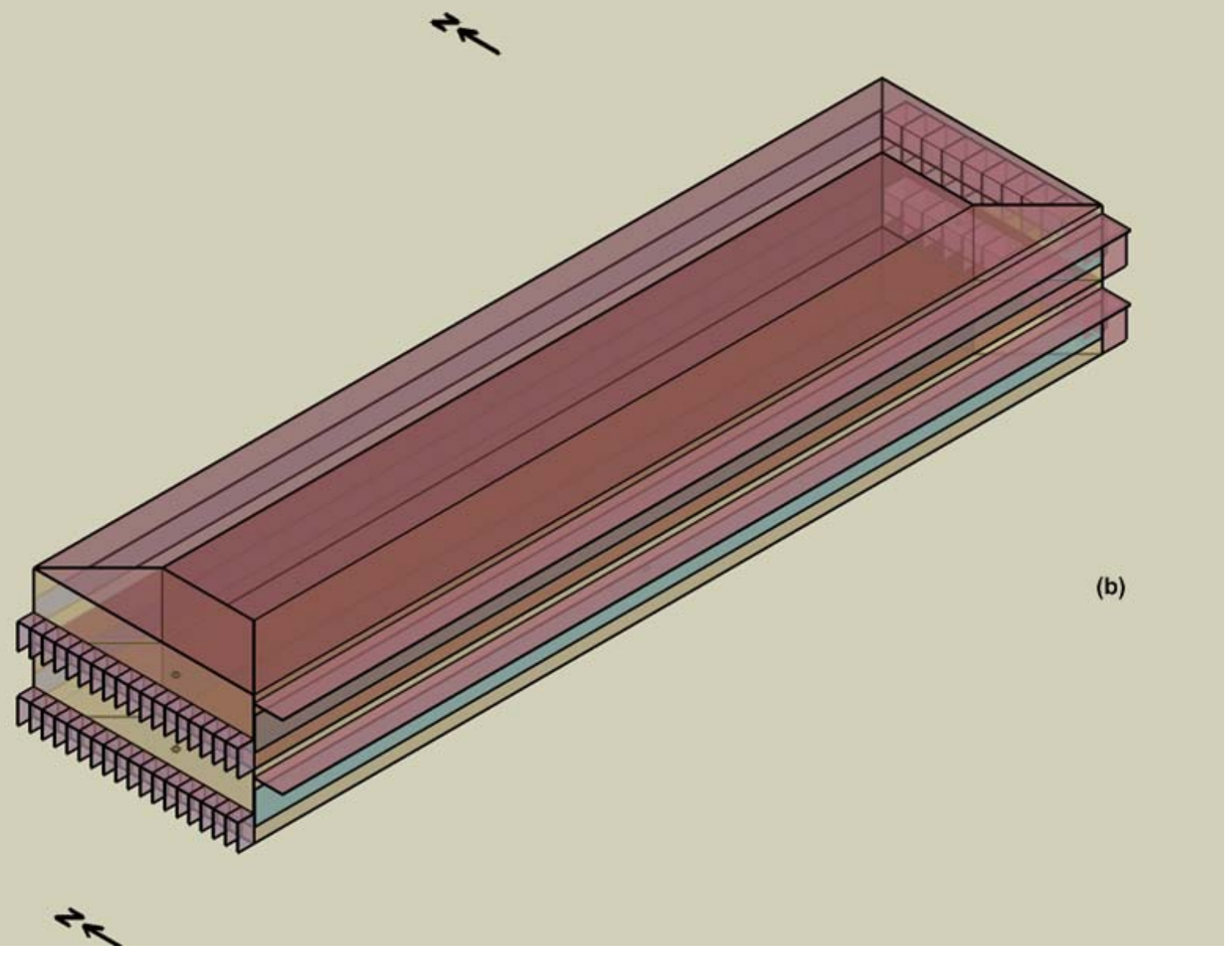

Figure 3-2 Example form changes for Passive Solar scenarios: (a) before and (b) after changes 


\section{RESULTS AND DISCUSSION}

As described in previous sections, we modeled each building under scenarios that evaluate ZEB technologies and practices to arrive at a projection of what might be achievable by 2025 . In the first subsection we present overall results in simple terms of meeting the ZEB goal. The second subsection discusses how programmatic factors affect the ability to achieve zero. Results by individual end uses are discussed in the third subsection. The fourth subsection presents results from investigations of individual technologies and practices. The fifth subsection discusses the results and provides recommendations.

\subsection{ZEB Opportunities in Commercial Buildings}

The casual observer will rightly note that large office buildings are much too large and energy intensive to reach the ZEB goal. Much of the sector, though, consists of entirely different types of buildings, a significant number of which could meet the ZEB goal. For the modeling conducted in this assessment, NREL used a package of ZEB technologies and practices that included a roof half-covered with a PV power system along with a range of efficiency measures. In some cases this could produce ample excess power, and might even surpass the ZEB goal. The challenge here is to analyze the issue in a way that accounts for the relative numbers of all the different types of buildings and leads to the evaluation of the ZEB goal for the sector as a whole. For this reason, we based our core methodology on statistical sampling of the sector developed by EIA for 2003 CBECS (EIA 2006).

The simplest way to express the opportunities for ZEBs in the sector is to determine the percentage of total floor area, or the total number of buildings, that could meet the ZEB goal. Based on a ZEB definition that uses net site energy use of zero or less, the results show that $47 \%$ of commercial floor area and $62 \%$ of buildings could reach ZEB by using known technologies and practices with projected performance levels for 2025. These results indicate that the ZEB goal is not too aggressive and can be achieved for large segments of the commercial sector.

We computed many Max Tech scenarios and compared them to baseline building models that were derived from a consensus standard (ASHRAE 2004). Figure 4-1 shows the percentage of the sector that can meet the ZEB goal under the modeled scenarios, in terms of both overall floor area and overall number of buildings. Figure 4-2 and Figure 4-3 show the average total and net site EUIs for the entire sector. These results are presented in both "net," which includes PV power systems, and "total," which includes only changes in consumption.

Table 4-1 and Table 4-2 use a variety of use intensity metrics to compare the Max Tech scenario to the Base scenario. The results show that future buildings have, on average, the potential to use $83 \%$ less site energy on an annual net basis. Source energy savings of up to $90 \%$ are possible. Peak electrical demand reductions of $51 \%$ were modeled. Electricity savings of $39 \%$ and natural gas savings of $50 \%$ were found. Energy costs are reduced by $42 \%$.

Although mean values are easy to interpret, performance actually varies widely across the sector, and it is useful to examine how EUIs are distributed using PDFs. Figure 4-4 plots PDF curves for several key scenarios. The curves show the relative portion of the sector (by area) as a function of EUI. The curve for "Max Tech no PV" is from the Max Tech scenario but based on total rather than net EUI. The PDFs all have long tails that extend well beyond right-hand side of the plot. The PDFs for the existing stock models that were used to create the Base scenario; the 2003 CBECS survey data are also plotted in Figure 4-4 (Griffith et al. 2008). A histogram analysis that sorted the samples into EUI bins with increments of $20 \mathrm{kBtu} / \mathrm{ft}^{2} \cdot \mathrm{yr}\left(227 \mathrm{MJ} / \mathrm{m}^{2} \cdot \mathrm{yr}\right)$ was used to generate the PDF curves (and others in this report). The PDFs here and elsewhere in this report are weighted based on area rather than on number of buildings.

The results show that the addition of energy efficiency decreases the amount of spread in EUIs and the addition of on-site PV increases the spread. 


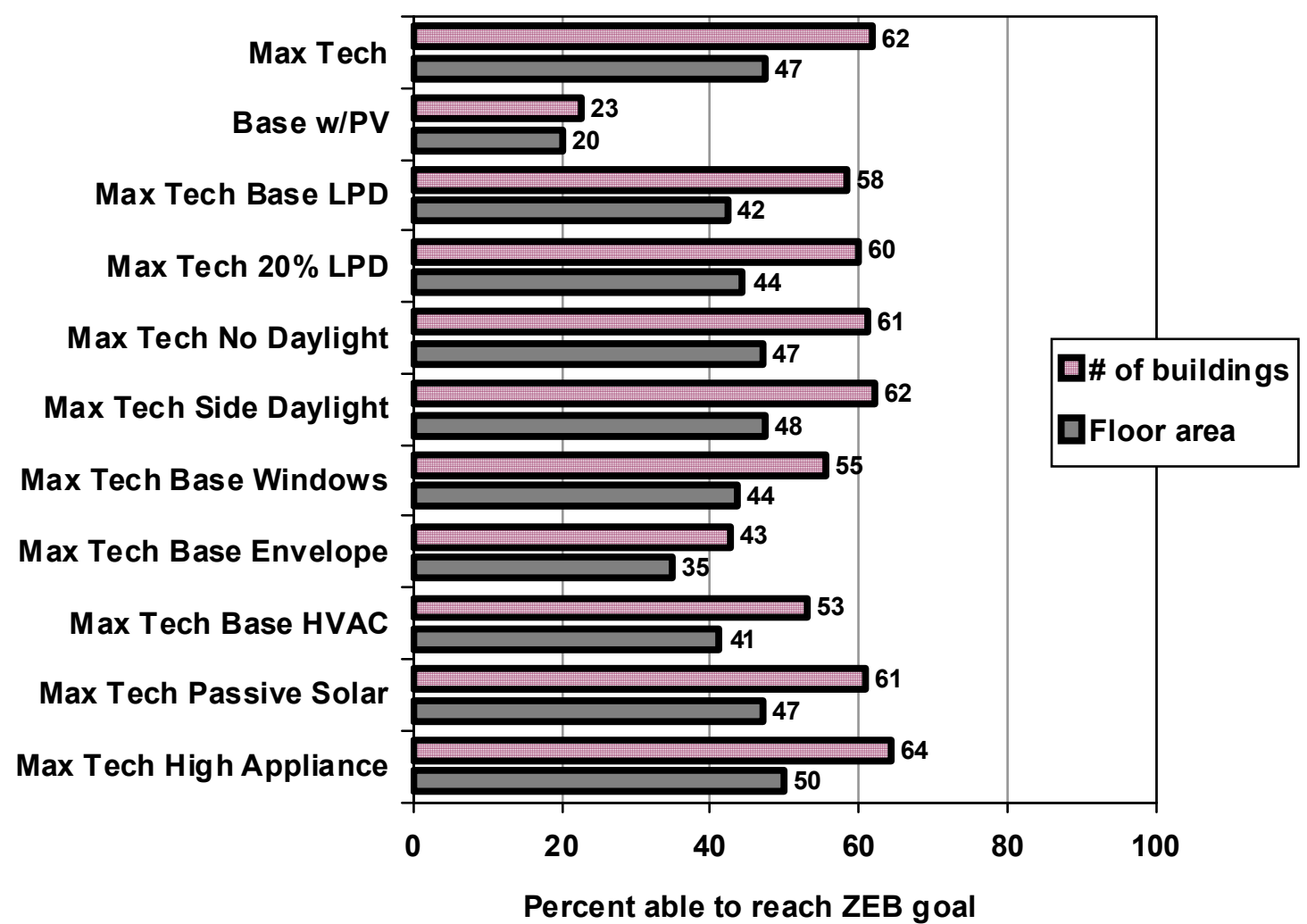

Figure 4-1 Percentage of U.S. commercial buildings sector that can reach the ZEB goal under various scenarios

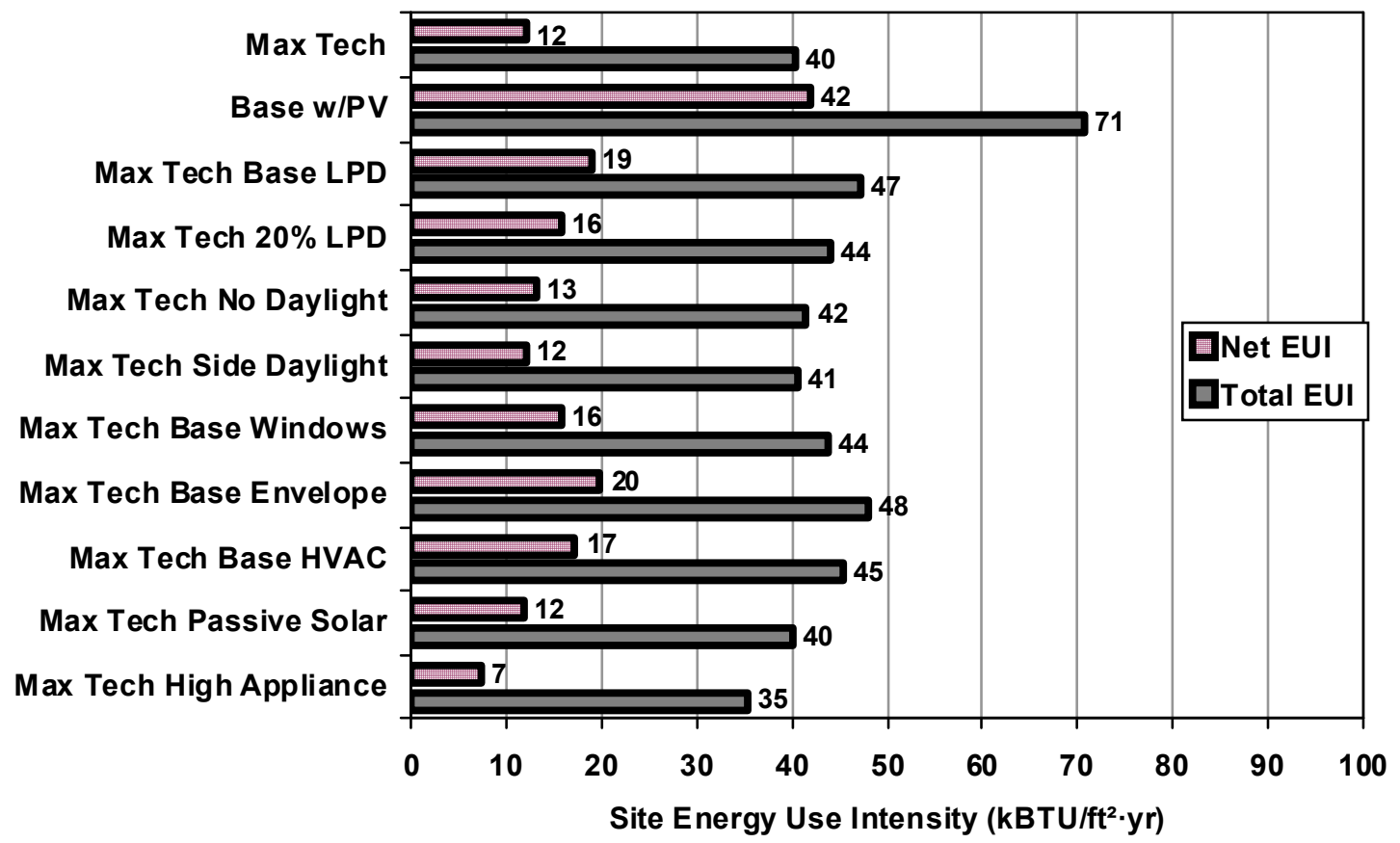

Figure 4-2 Mean site EUls for entire sector under various scenarios: IP Units (kBtu/ft $\left.{ }^{2} \cdot \mathrm{yr}\right)$ 


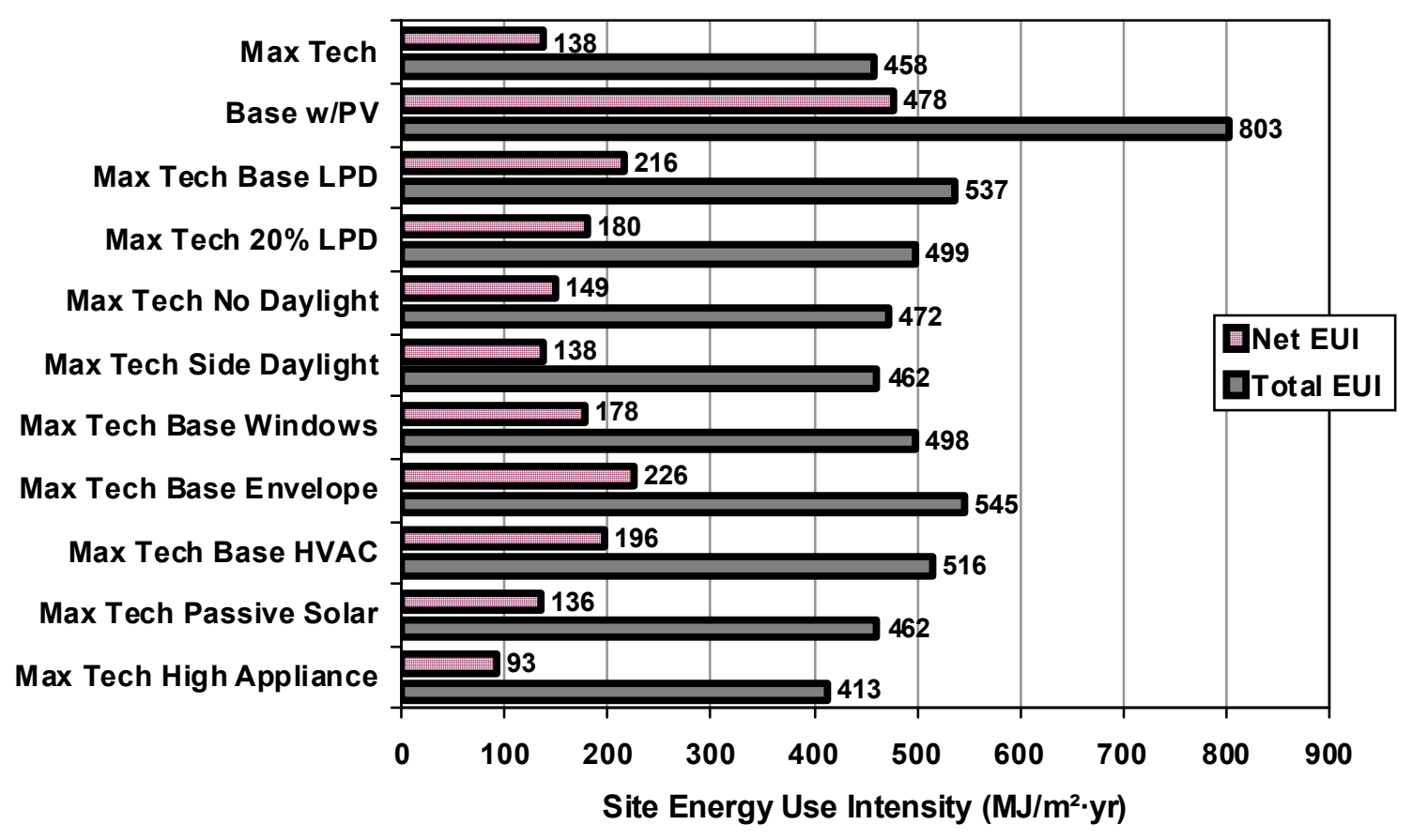

Figure 4-3 Mean site EUls for entire sector for various scenarios: SI Units $\left(\mathrm{MJ} / \mathrm{m}^{2} \cdot \mathrm{yr}\right)$

Table 4-1 Sector-Wide Average Use Intensity Metrics for Base and Max Tech Scenarios: IP units

\begin{tabular}{|l|c|c|c|}
\hline \multicolumn{1}{|c|}{ Use Intensity Metric } & Base & Max Tech & Savings from Base \\
\hline Total site $\left(\mathrm{kBtu} / \mathrm{ft}^{2} \cdot \mathrm{yr}\right)$ & 70.7 & 40.3 & $43 \%$ \\
\hline $\mathrm{PV}$ production $\left(\mathrm{kBtu} / \mathrm{ft}^{2} \cdot \mathrm{yr}\right)$ & 0.0 & 28.1 & $\mathrm{~N} / \mathrm{A}$ \\
\hline Net site $\left(\mathrm{kBtu} / \mathrm{ft}^{2} \cdot \mathrm{yr}\right)$ & 70.7 & 12.2 & $83 \%$ \\
\hline Lights $\left(\mathrm{kBtu} / \mathrm{ft}^{2} \cdot \mathrm{yr}\right)$ & 12.6 & 4.5 & $64 \%$ \\
\hline Cooling equipment $\left(\mathrm{kBtu} / \mathrm{ft}^{2} \cdot \mathrm{yr}\right)$ & 9.1 & 5.2 & $43 \%$ \\
\hline Heating equipment $\left(\mathrm{kBtu} / \mathrm{ft}^{2} \cdot \mathrm{yr}\right)$ & 17.5 & 5.2 & $70 \%$ \\
\hline Fans $\left(\mathrm{kBtu} / \mathrm{ft}^{2} \cdot \mathrm{yr}\right)$ & 4.6 & 1.7 & $63 \%$ \\
\hline Pumps $\left(\mathrm{kBtu} / \mathrm{ft}^{2} \cdot \mathrm{yr}\right)$ & 0.54 & 0.38 & $30 \%$ \\
\hline Plug and process electricity $\left(\mathrm{kBtu} / \mathrm{ft}^{2} \cdot \mathrm{yr}\right)$ & 10.1 & 10.1 & $0 \%$ \\
\hline Process gas $\left(\mathrm{kBtu} / \mathrm{ft}^{2} \cdot \mathrm{yr}\right)$ & 5.3 & 5.3 & $0 \%$ \\
\hline Refrigeration $\left(\mathrm{kBtu} / \mathrm{ft}^{2} \cdot \mathrm{yr}\right)$ & 4.4 & 3.1 & $30 \%$ \\
\hline Service water heating $\left(\mathrm{kBtu} / \mathrm{ft}^{2} \cdot \mathrm{yr}\right)$ & 2.5 & 2.3 & $8 \%$ \\
\hline Total site electricity $\left(\mathrm{kBtu} / \mathrm{ft}^{2} \cdot \mathrm{yr}\right)$ & 46.0 & 27.9 & $39 \%$ \\
\hline Gas $\left(\mathrm{kBtu} / \mathrm{ft}^{2} \cdot \mathrm{yr}\right)$ & 24.4 & 12.1 & $50 \%$ \\
\hline Net source $\left(\mathrm{kBtu} / \mathrm{ft}^{2} \cdot \mathrm{yr}\right)$ & 156.7 & 16.0 & $90 \%$ \\
\hline Peak electrical demand $\left(\mathrm{W} / \mathrm{ft}^{2}\right)$ & 5.1 & 2.5 & $51 \%$ \\
\hline Energy water $\left(\mathrm{gal} / \mathrm{ft}^{2} \cdot \mathrm{yr}\right)$ & 17.7 & 7.0 & $60 \%$ \\
\hline Energy cost $\left(\$ / \mathrm{ft}^{2} \cdot \mathrm{yr}\right)$ & 1.52 & 0.88 & $42 \%$ \\
\hline Energy equivalent carbon $\left(\mathrm{lb} / \mathrm{ft}^{2} \cdot \mathrm{yr}\right)$ & 10.2 & 4.2 & $59 \%$ \\
\hline
\end{tabular}


Table 4-2 Sector-Wide Average Use Intensity Metrics for Base and Max Tech Scenarios: SI units

\begin{tabular}{|l|c|c|c|}
\hline \multicolumn{1}{|c|}{ Use Intensity Metric } & Base & Max Tech & Savings from Base \\
\hline \hline Total site $\left(\mathrm{MJ} / \mathrm{m}^{2} \cdot \mathrm{yr}\right)$ & 803 & 458 & $43 \%$ \\
\hline PV production $\left(\mathrm{MJ} / \mathrm{m}^{2} \cdot \mathrm{yr}\right)$ & 0 & 319 & $\mathrm{~N} / \mathrm{A}$ \\
\hline Net site $\left(\mathrm{MJ} / \mathrm{m}^{2} \cdot \mathrm{yr}\right)$ & 803 & 139 & $83 \%$ \\
\hline Lights $\left(\mathrm{MJ} / \mathrm{m}^{2} \cdot \mathrm{yr}\right)$ & 143 & 51 & $64 \%$ \\
\hline Cooling equipment $\left(\mathrm{MJ} / \mathrm{m}^{2} \cdot \mathrm{yr}\right)$ & 103 & 59 & $43 \%$ \\
\hline Heating equipment $\left(\mathrm{MJ} / \mathrm{m}^{2} \cdot \mathrm{yr}\right)$ & 199 & 59 & $70 \%$ \\
\hline Fans $\left(\mathrm{MJ} / \mathrm{m}^{2} \cdot \mathrm{yr}\right)$ & 52 & 19 & $63 \%$ \\
\hline Pumps $\left(\mathrm{MJ} / \mathrm{m}^{2} \cdot \mathrm{yr}\right)$ & 6 & 4 & $30 \%$ \\
\hline Plug and process electricity $\left(\mathrm{MJ} / \mathrm{m}^{2} \cdot \mathrm{yr}\right)$ & 115 & 115 & $0 \%$ \\
\hline Process gas $\left(\mathrm{MJ} / \mathrm{m}^{2} \cdot \mathrm{yr}\right)$ & 60 & 60 & $0 \%$ \\
\hline Refrigeration $\left(\mathrm{MJ} / \mathrm{m}^{2} \cdot \mathrm{yr}\right)$ & 50 & 35 & $30 \%$ \\
\hline Service water heating $\left(\mathrm{MJ} / \mathrm{m}^{2} \cdot \mathrm{yr}\right)$ & 28 & 26 & $8 \%$ \\
\hline Total site electricity $\left(\mathrm{MJ} / \mathrm{m}^{2} \cdot \mathrm{yr}\right)$ & 523 & 317 & $39 \%$ \\
\hline Gas $\left(\mathrm{MJ} / \mathrm{m}^{2} \cdot \mathrm{yr}\right)$ & 277 & 138 & $50 \%$ \\
\hline Net source $\left(\mathrm{MJ} / \mathrm{m}^{2} \cdot \mathrm{yr}\right)$ & 1781 & 182 & $90 \%$ \\
\hline Peak electrical demand $\left(\mathrm{W} / \mathrm{m}^{2}\right)$ & 55 & 27 & $51 \%$ \\
\hline Energy water $\left(\mathrm{l} / \mathrm{m}^{2} \cdot \mathrm{yr}\right)$ & 721 & 285 & $60 \%$ \\
\hline Energy cost $\left(\$ / \mathrm{m}^{2} \cdot \mathrm{yr}\right)$ & 16.36 & 9.47 & $42 \%$ \\
\hline Energy equivalent carbon $\left(\mathrm{kg} / \mathrm{m}^{2} \cdot \mathrm{yr}\right)$ & 49.8 & 20.5 & $59 \%$ \\
\hline
\end{tabular}

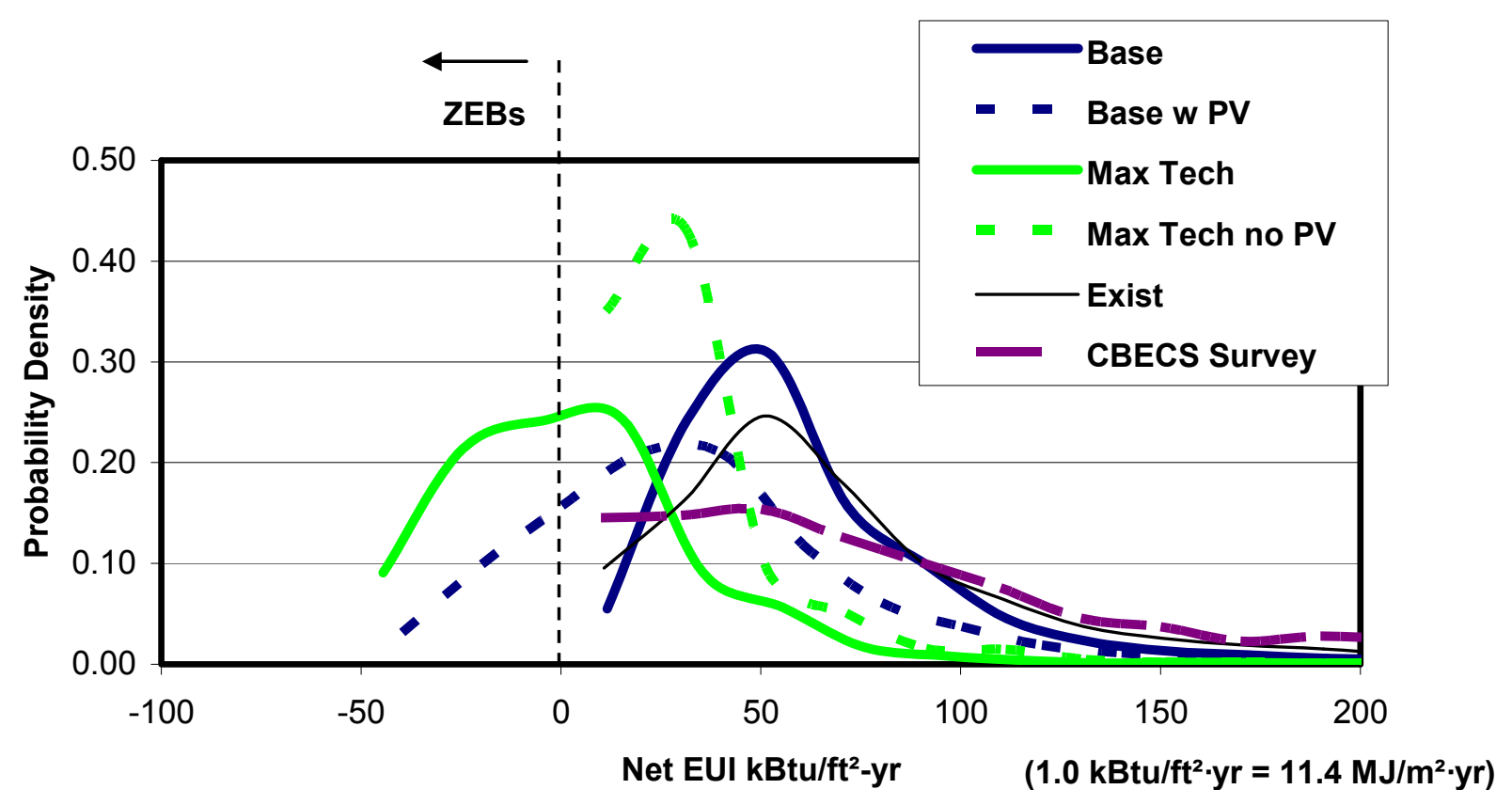

Figure 4-4 PDFs for net EUI for three scenarios 


\subsection{Programmatic Factors for Meeting the ZEB Goal}

This section discusses how the programmatic requirements of buildings (architectural program elements) influence the ability of buildings to reach the ZEB goal.

\subsubsection{Plug and Process Loads}

Buildings with lower plug and process loads are expected to more easily reach ZEB, and the results of this study can quantify this notion. In this section, occupant-driven plug and process energy includes electricity and natural gas used to power all kinds of appliances and process equipment that are nonHVAC\&L. Figure 4-5 shows the effect of non-HVAC\&L energy use on the fraction of floor area that can reach zero, along with the distribution (in red) of non-HVAC\&L energy use in the models. The plot suggests a curve (in blue) that would describe the relationship between occupant-driven energy use and the part of the sector that can reach ZEB. The magnitudes of non-HVAC\&L loads used in the modeling were generated probabilistically from assumptions and are described in Appendix $\mathrm{C}$ of Griffith et al. (2008). As a result, the probability distributions given here reflect what was used in the study, rather than detailed knowledge of the sector. Figure 4-5 shows that meeting the ZEB goal is easier for lower nonHVAC\&L energy use. Our results suggest that the ZEB context differs from the traditional approach to energy-efficient design in that non-HVAC\&L loads must be considered rather than treated as fixed, or unregulated, and therefore largely ignored.

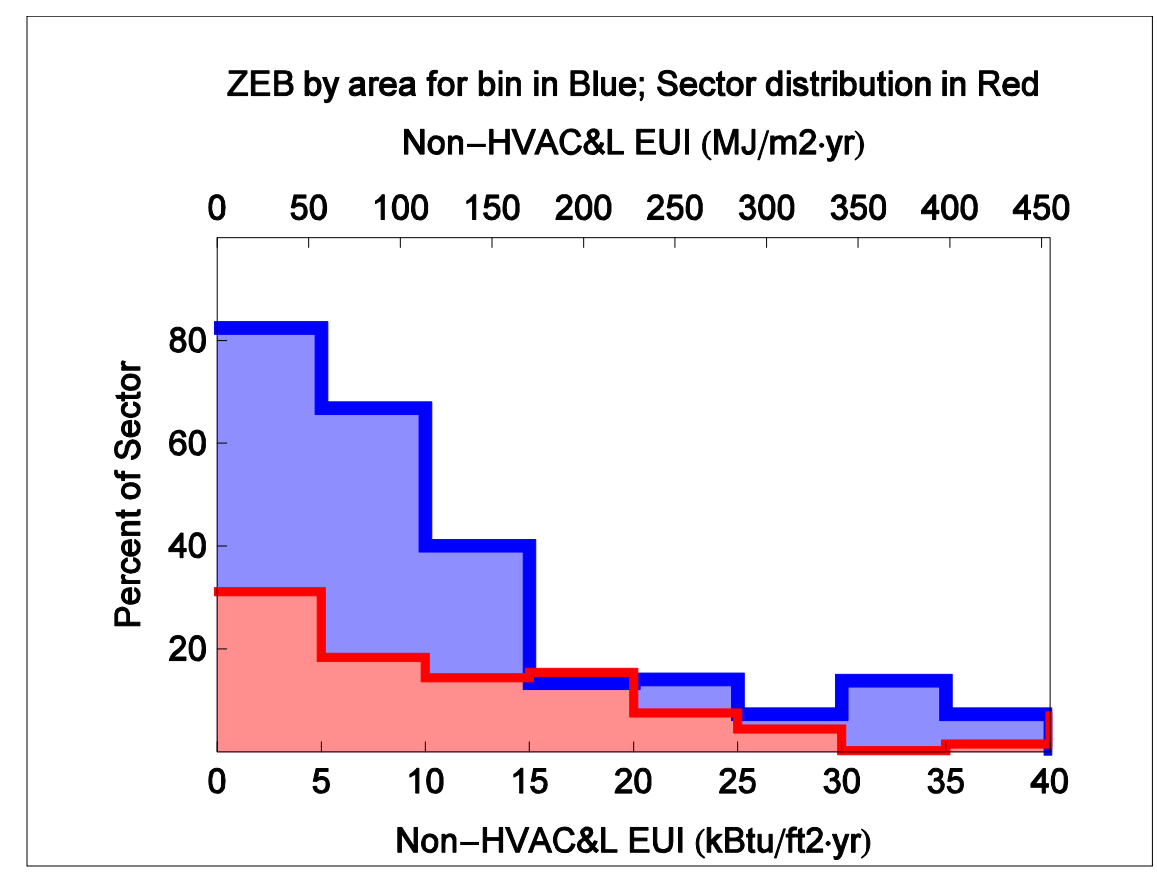

Figure 4-5 Percentage of floor area that can reach ZEB as a function of non-HVAC\&L EUI: Max Tech Scenario

\subsubsection{Number of Floors}

Figure 4-6 shows that the effect of the number of floors is a strong indicator of the building's ability to reach zero energy building. Single-story buildings offer a large amount of roof area per usable floor area for PV power-generating capacity. Single-story buildings can also be more easily daylit. For reference, Figure 4-6 shows the distribution (in red) of commercial floor area as a function of the number of floors. Buildings with more than four stories, for example, are unlikely to attain the ZEB goal. Although 13\% of commercial floor area has more than six stories, $40 \%$ of the sector is single-story buildings. Of these, $85 \%$ could reach ZEB under the Max Tech Scenario. 


\subsubsection{Building Floor Area}

Our analysis showed that, there are enough large-area, single-story buildings to make overall building size a poor indicator for ZEB opportunity in the sector. Figure 4-7 shows the fraction of commercial floor area that can reach zero as a function of the total floor area of each building. The probability density of each floor area bin is indicated for reference. Although smaller buildings have an advantage in reaching the ZEB goal, the effect is weaker than might be assumed, with relatively small changes up to $200,000 \mathrm{ft}^{2}$ $\left(18,580 \mathrm{~m}^{2}\right)$. This shows that overall building size is not necessarily a good way to distinguish which parts of the sector should be the focus of ZEB research.

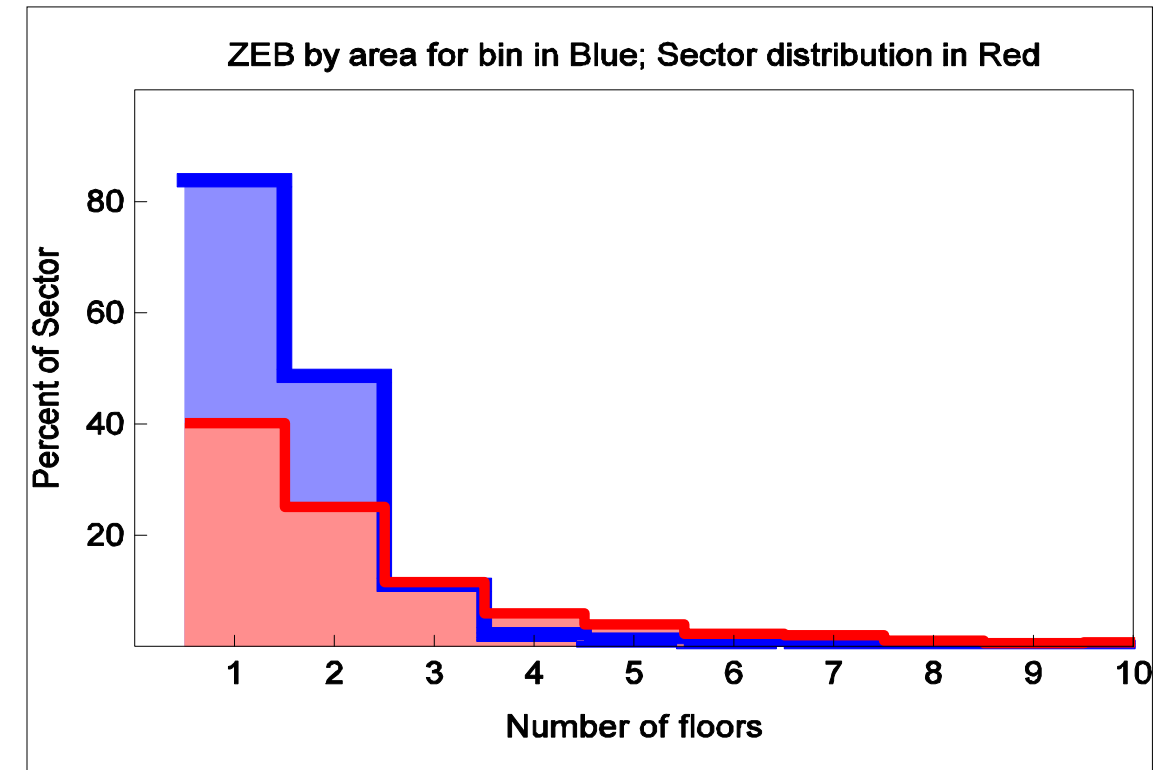

Figure 4-6 Percentage of floor area that can reach ZEB as a function of number of floors in building: Max Tech scenario

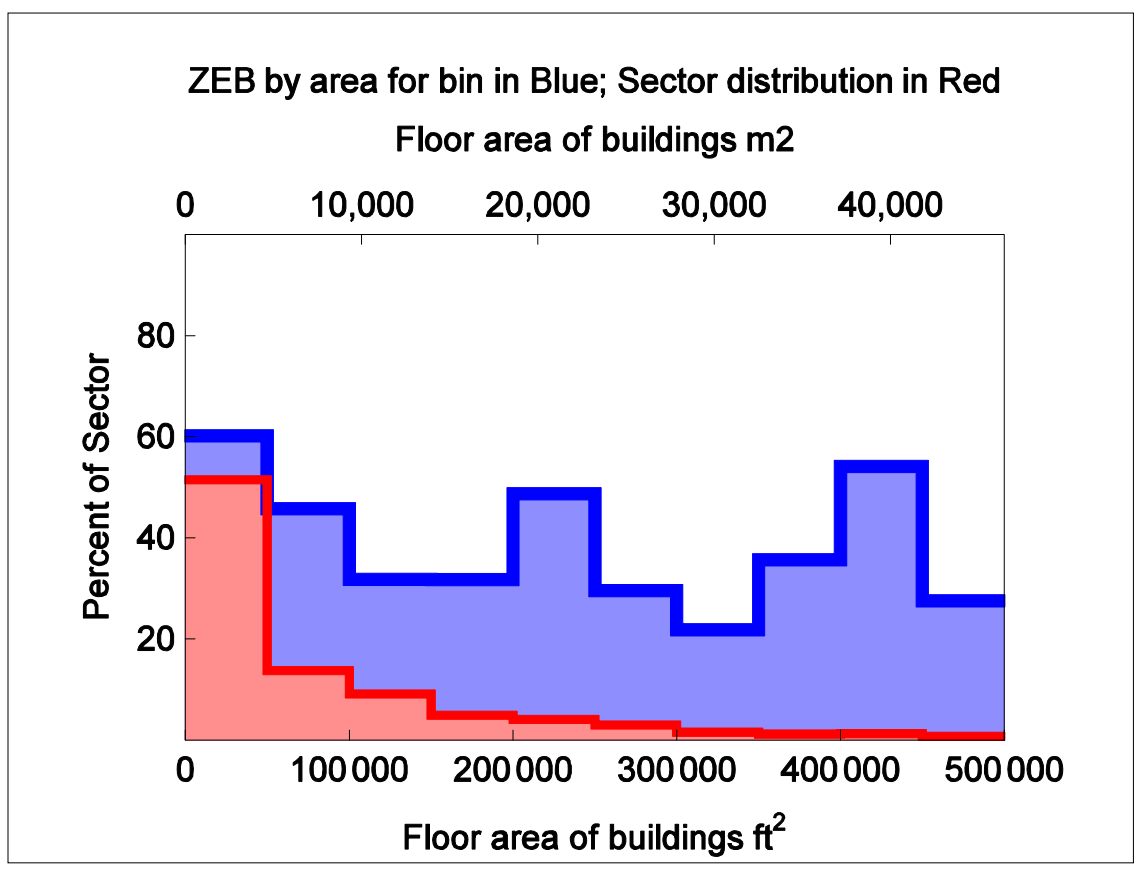

Figure 4-7 Percentage of floor area that can reach ZEB for various total floor areas: Max Tech scenario 


\subsubsection{Location}

This section examines how building location affects technical potential. The two methods of categorizing locations in this study are climate zones and census divisions, which are discussed in the next two subsections. A third subsection organizes results based on solar resources.

Regional differences influence the results for reasons other than the weather. The Northeast has relatively high numbers of multistory buildings; the South has more single-story buildings. From modeling energy costs with regional variations, we discovered that savings levels differ across regions. Greater cost savings were seen in the West North Central and East South Central census divisions and lower cost savings were found in the West South Central and Pacific divisions. The fuel mixes used to generate electricity were also modeled, but results for carbon savings were uniform to within $5 \%$ across the census divisions. Similarly, levels of savings in percentage of water use that is attributable to electricity production were determined; the highest saving percentages were in the South Atlantic and East South Central divisions and the lowest were in the Middle Atlantic, New England, and Pacific divisions.

\subsubsection{Climate zones}

Developers of codes and standards have organized U.S. regions into climate zones. Figure 4-8 shows the eight major climate zones, which were developed by DOE and are now used in ASHRAE Standards (ASHRAE 2004a). We used this classification for climates in this study.

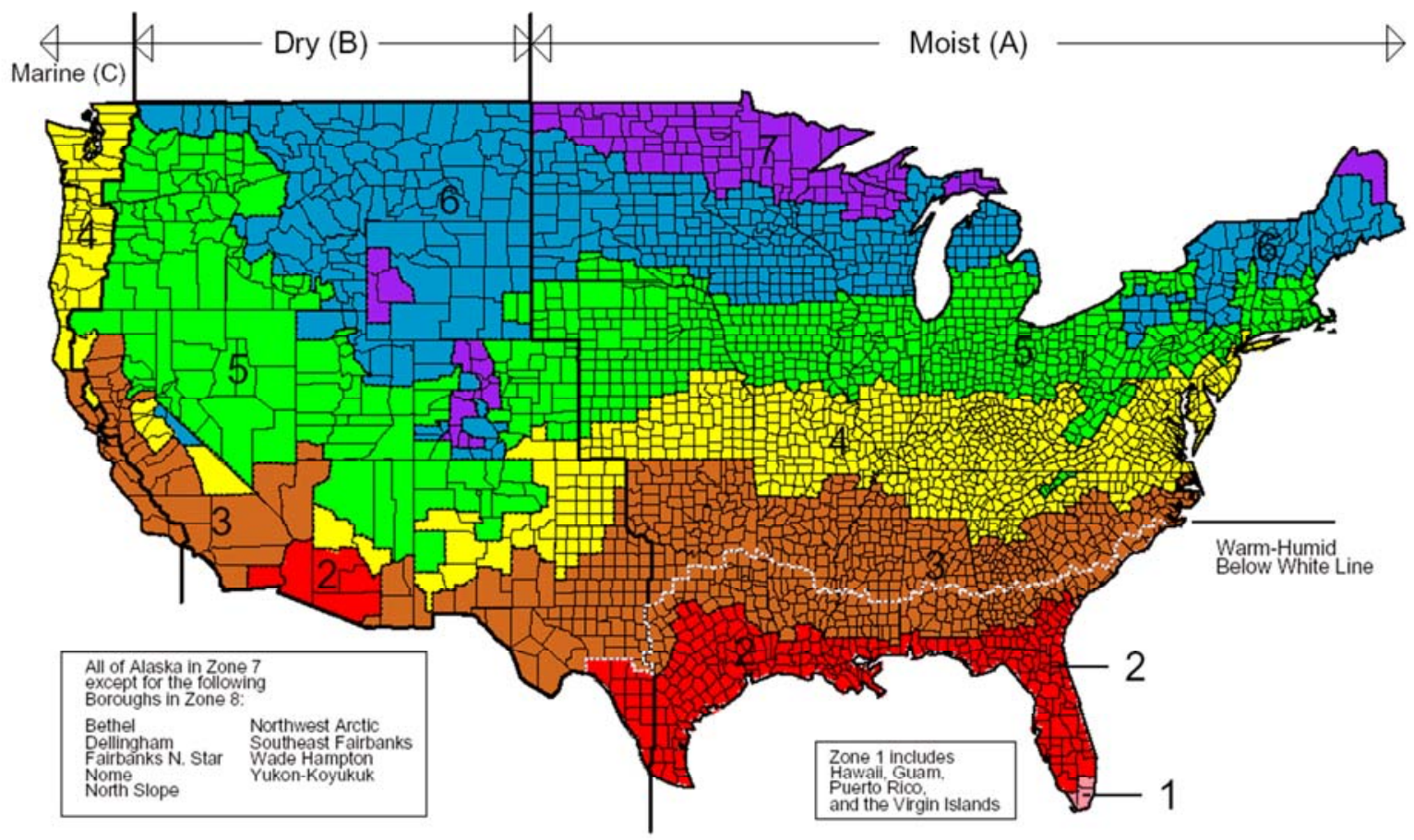

March 24, 2003

Figure 4-8 Map of DOE's climate zones ${ }^{2}$

\footnotetext{
${ }^{2}$ Source: www.energycodes.gov/implement/pdfs/color_map_climate_zones_Mar03.pdf
} 
Results were sorted and weighted among all the buildings in each climate zone. Table 4-3 shows the percentage of floor area that can reach the ZEB goal for the climate zones and Max Tech scenarios. Table 4-4 and Table 4-5 show how percent savings in net site energy vary for the climate zones and scenarios. The method of assigning locations (and therefore climate zones) to the 2003 CBECS buildings is discussed in Appendix $\mathrm{C}$ of Griffith et al. (2008). No buildings were assigned to climate zone 8. Climate zones 1A, 2B, 3C, 4B, 4C, and 7 have relatively few buildings, as indicated by the number of models in Table 4-3.

The results show that climate zones $2 \mathrm{~A}, 3 \mathrm{~A}, 3 \mathrm{~B}, 4 \mathrm{~B}, 5 \mathrm{~B}$, and $6 \mathrm{~B}$ have the best prospects for achieving the ZEB goal. The worst prospects are for the coldest climate 7 and the humid climates $3 \mathrm{C}$ and $4 \mathrm{C}$. Of the climate zones with enough models for meaningful weighted averages (estimated at $\mathrm{N}>100$ ), the lowest EUI climate zones in the Base context are 3B, 5B, and 2A; but in the ZEB context, the lowest EUI zones are $6 \mathrm{~B}, 5 \mathrm{~B}, 3 \mathrm{~B}$, and $2 \mathrm{~A}$. Opaque thermal insulation and advanced $\mathrm{HVAC}$ technologies are noticeable in that they become increasingly more important in colder climates. 
Table 4-3 Percentage of Floor Area Able to Reach ZEB by Climate Zone for Various Scenarios

\begin{tabular}{|c|c|c|c|c|c|c|c|c|c|c|}
\hline $\begin{array}{l}\text { Climate } \\
\text { Zone }\end{array}$ & $\begin{array}{l}\text { Num } \\
\text { model }\end{array}$ & $\begin{array}{c}\text { Base w/ } \\
\text { PV }\end{array}$ & $\begin{array}{l}\text { Max } \\
\text { Tech }\end{array}$ & $\begin{array}{l}\text { Max Tech } \\
\text { Base LPD }\end{array}$ & $\begin{array}{c}\text { Max Tech } \\
\text { No } \\
\text { Daylight }\end{array}$ & $\begin{array}{c}\text { Max Tech } \\
\text { Base } \\
\text { Windows }\end{array}$ & $\begin{array}{c}\text { Max Tech } \\
\text { Base } \\
\text { Envelope }\end{array}$ & $\begin{array}{c}\text { Max Tech } \\
\text { Base } \\
\text { HVAC }\end{array}$ & $\begin{array}{c}\text { Max Tech } \\
\text { Passive } \\
\text { Solar }\end{array}$ & $\begin{array}{c}\text { Max Tech } \\
\text { High } \\
\text { Appliance }\end{array}$ \\
\hline All & 4,820 & $20 \%$ & $47 \%$ & $42 \%$ & $47 \%$ & $44 \%$ & $35 \%$ & $41 \%$ & $47 \%$ & $50 \%$ \\
\hline $1 \mathrm{~A}$ & 40 & $32 \%$ & $41 \%$ & $36 \%$ & $37 \%$ & $37 \%$ & $37 \%$ & $37 \%$ & $41 \%$ & $49 \%$ \\
\hline $2 \mathrm{~A}$ & 542 & $38 \%$ & $58 \%$ & $51 \%$ & $57 \%$ & $56 \%$ & $51 \%$ & $56 \%$ & $59 \%$ & $60 \%$ \\
\hline $2 B$ & 24 & $14 \%$ & $42 \%$ & $42 \%$ & $42 \%$ & $42 \%$ & $42 \%$ & $40 \%$ & $42 \%$ & $42 \%$ \\
\hline $3 A$ & 464 & $36 \%$ & $60 \%$ & $54 \%$ & $58 \%$ & $56 \%$ & $50 \%$ & $56 \%$ & $60 \%$ & $63 \%$ \\
\hline $3 B$ & 452 & $36 \%$ & $60 \%$ & $54 \%$ & $59 \%$ & $59 \%$ & $57 \%$ & $58 \%$ & $60 \%$ & $62 \%$ \\
\hline $3 C$ & 52 & $25 \%$ & $28 \%$ & $28 \%$ & $28 \%$ & $28 \%$ & $28 \%$ & $28 \%$ & $28 \%$ & $29 \%$ \\
\hline $4 \mathrm{~A}$ & 982 & $14 \%$ & $43 \%$ & $38 \%$ & $42 \%$ & $39 \%$ & $32 \%$ & $37 \%$ & $42 \%$ & $45 \%$ \\
\hline 4B & 64 & $39 \%$ & $61 \%$ & $57 \%$ & $64 \%$ & $58 \%$ & $51 \%$ & $60 \%$ & $61 \%$ & $65 \%$ \\
\hline $4 C$ & 50 & $9 \%$ & $30 \%$ & $24 \%$ & $26 \%$ & $22 \%$ & $21 \%$ & $24 \%$ & $29 \%$ & $30 \%$ \\
\hline $5 \mathrm{~A}$ & 1,152 & $10 \%$ & $41 \%$ & $37 \%$ & $41 \%$ & $35 \%$ & $23 \%$ & $33 \%$ & $40 \%$ & $43 \%$ \\
\hline $5 B$ & 262 & $23 \%$ & $64 \%$ & $53 \%$ & $64 \%$ & $60 \%$ & $46 \%$ & $53 \%$ & $64 \%$ & $68 \%$ \\
\hline $6 \mathrm{~A}$ & 519 & $5 \%$ & $37 \%$ & $33 \%$ & $39 \%$ & $30 \%$ & $16 \%$ & $25 \%$ & $36 \%$ & $40 \%$ \\
\hline $6 B$ & 120 & $19 \%$ & $60 \%$ & $54 \%$ & $60 \%$ & $58 \%$ & $41 \%$ & $49 \%$ & $60 \%$ & $68 \%$ \\
\hline 7 & 97 & $3 \%$ & $25 \%$ & $24 \%$ & $24 \%$ & $22 \%$ & $8 \%$ & $18 \%$ & $23 \%$ & $26 \%$ \\
\hline
\end{tabular}


Table 4-4 Net Site EUI for Various Scenarios by Climate Zone: IP Units (kBtu/ft' $\left.{ }^{2} \cdot \mathrm{yr}\right)$

\begin{tabular}{|c|c|c|c|c|c|c|c|c|c|c|c|}
\hline $\begin{array}{c}\text { Climate } \\
\text { Zone }\end{array}$ & $\begin{array}{l}\text { Num } \\
\text { model }\end{array}$ & Base & $\begin{array}{c}\text { Base w/ } \\
\text { PV }\end{array}$ & $\begin{array}{l}\text { Max } \\
\text { Tech }\end{array}$ & $\begin{array}{l}\text { Max } \\
\text { Tech } \\
\text { Base } \\
\text { LPD }\end{array}$ & $\begin{array}{c}\text { Max } \\
\text { Tech No } \\
\text { Daylight }\end{array}$ & $\begin{array}{c}\text { Max Tech } \\
\text { Base } \\
\text { Windows }\end{array}$ & $\begin{array}{c}\text { Max Tech } \\
\text { Base } \\
\text { Envelope }\end{array}$ & $\begin{array}{c}\text { Max Tech } \\
\text { Base } \\
\text { HVAC }\end{array}$ & $\begin{array}{c}\text { Max Tech } \\
\text { Passive } \\
\text { Solar }\end{array}$ & $\begin{array}{c}\text { Max Tech } \\
\text { High } \\
\text { Appliance }\end{array}$ \\
\hline All & 4,820 & 70.7 & 42.2 & 12.2 & 17.6 & 13.0 & 15.7 & 20.2 & 17.3 & 11.9 & 7.3 \\
\hline $1 \mathrm{~A}$ & 40 & 82.3 & 46.3 & 19.8 & 26.1 & 22.0 & 19.0 & 20.1 & 25.4 & 17.1 & 11.1 \\
\hline $2 \mathrm{~A}$ & 542 & 67.6 & 32.7 & 7.4 & 13.4 & 8.1 & 10.0 & 13.4 & 10.5 & 6.9 & 2.2 \\
\hline $2 B$ & 24 & 72.8 & 37.4 & 9.4 & 20.8 & 10.4 & 12.9 & 14.9 & 9.0 & 8.4 & 3.1 \\
\hline $3 A$ & 464 & 77.6 & 42.4 & 13.4 & 19.8 & 14.6 & 16.0 & 20.2 & 18.7 & 12.9 & 6.6 \\
\hline $3 B$ & 452 & 57.8 & 22.6 & 2.9 & 8.1 & 4.3 & 4.2 & 6.5 & 5.6 & 2.4 & -2.3 \\
\hline $3 C$ & 52 & 62.2 & 44.2 & 27.3 & 33.1 & 29.2 & 29.4 & 27.5 & 28.4 & 25.6 & 19.2 \\
\hline $4 \mathrm{~A}$ & 982 & 70.4 & 44.7 & 13.6 & 19.7 & 14.6 & 17.1 & 21.5 & 18.9 & 13.2 & 8.9 \\
\hline $4 \mathrm{~B}$ & 64 & 55.3 & 18.9 & -8.0 & -3.2 & -7.4 & -6.5 & -0.8 & -2.4 & -8.2 & -10.9 \\
\hline $4 C$ & 50 & 55.8 & 38.3 & 15.5 & 21.5 & 16.7 & 19.9 & 21.2 & 17.1 & 14.9 & 11.2 \\
\hline $5 A$ & 1,152 & 74.9 & 51.2 & 18.5 & 23.7 & 19.3 & 23.2 & 27.7 & 24.2 & 18.6 & 13.6 \\
\hline $5 B$ & 262 & 64.4 & 29.3 & 1.5 & 6.5 & 2.8 & 5.0 & 9.5 & 4.6 & 1.4 & -2.1 \\
\hline $6 \mathrm{~A}$ & 519 & 75.8 & 51.8 & 13.9 & 17.6 & 14.0 & 19.1 & 26.4 & 21.9 & 14.4 & 10.2 \\
\hline $6 \mathrm{~B}$ & 120 & 73.5 & 35.9 & -2.0 & 2.8 & -1.3 & 1.0 & 10.1 & 7.1 & -1.6 & -5.5 \\
\hline 7 & 97 & 74.0 & 50.9 & 12.7 & 16.2 & 13.0 & 17.5 & 26.9 & 20.5 & 13.1 & 9.9 \\
\hline
\end{tabular}


Table 4-5 Net Site EUI for Various Scenarios by Climate Zone: SI Units $\left(\mathrm{MJ} / \mathrm{m}^{2} \cdot \mathrm{yr}\right)$

\begin{tabular}{|c|c|c|c|c|c|c|c|c|c|c|c|}
\hline $\begin{array}{l}\text { Climate } \\
\text { Zone }\end{array}$ & $\begin{array}{l}\text { Num } \\
\text { model }\end{array}$ & Base & $\begin{array}{c}\text { Base w/ } \\
\text { PV }\end{array}$ & $\begin{array}{l}\text { Max } \\
\text { Tech }\end{array}$ & $\begin{array}{c}\text { Max } \\
\text { Tech } \\
\text { Base } \\
\text { LPD }\end{array}$ & $\begin{array}{c}\text { Max } \\
\text { Tech No } \\
\text { Daylight }\end{array}$ & $\begin{array}{c}\text { Max Tech } \\
\text { Base } \\
\text { Windows }\end{array}$ & $\begin{array}{c}\text { Max Tech } \\
\text { Base } \\
\text { Envelope }\end{array}$ & $\begin{array}{c}\text { Max Tech } \\
\text { Base } \\
\text { HVAC }\end{array}$ & $\begin{array}{c}\text { Max Tech } \\
\text { Passive } \\
\text { Solar }\end{array}$ & $\begin{array}{c}\text { Max Tech } \\
\text { High } \\
\text { Appliance }\end{array}$ \\
\hline All & 4,820 & 804 & 480 & 138 & 200 & 148 & 178 & 229 & 196 & 136 & 83 \\
\hline $1 \mathrm{~A}$ & 40 & 935 & 527 & 225 & 296 & 249 & 216 & 229 & 288 & 195 & 126 \\
\hline $2 \mathrm{~A}$ & 542 & 768 & 371 & 84 & 153 & 92 & 114 & 152 & 119 & 78 & 25 \\
\hline $2 B$ & 24 & 828 & 425 & 107 & 236 & 118 & 147 & 169 & 102 & 96 & 35 \\
\hline $3 \mathrm{~A}$ & 464 & 882 & 482 & 152 & 225 & 166 & 182 & 230 & 213 & 147 & 75 \\
\hline $3 B$ & 452 & 657 & 257 & 33 & 92 & 49 & 48 & 74 & 63 & 28 & -26 \\
\hline $3 C$ & 52 & 707 & 502 & 310 & 376 & 332 & 334 & 312 & 323 & 291 & 218 \\
\hline $4 \mathrm{~A}$ & 982 & 800 & 508 & 154 & 223 & 165 & 195 & 245 & 214 & 150 & 101 \\
\hline $4 \mathrm{~B}$ & 64 & 629 & 215 & -91 & -36 & -84 & -74 & -10 & -28 & -93 & -124 \\
\hline $4 C$ & 50 & 634 & 436 & 176 & 244 & 190 & 226 & 241 & 194 & 170 & 127 \\
\hline $5 A$ & 1,152 & 851 & 582 & 211 & 270 & 219 & 264 & 315 & 275 & 211 & 155 \\
\hline $5 B$ & 262 & 732 & 333 & 18 & 74 & 32 & 57 & 108 & 52 & 16 & -24 \\
\hline $6 \mathrm{~A}$ & 519 & 861 & 588 & 158 & 200 & 159 & 217 & 300 & 249 & 163 & 116 \\
\hline $6 \mathrm{~B}$ & 120 & 836 & 408 & -22 & 32 & -15 & 12 & 115 & 81 & -19 & -63 \\
\hline 7 & 97 & 841 & 578 & 144 & 184 & 148 & 199 & 306 & 233 & 149 & 113 \\
\hline
\end{tabular}




\subsubsection{Census divisions}

The 2003 CBECS public use statistical data distinguish regions of the United States by census division (variable CENDIV8). Figure 4-9 shows how the nine census divisions are defined by the U.S. Department of Commerce. We used this classification for geopolitical subregions in this study.

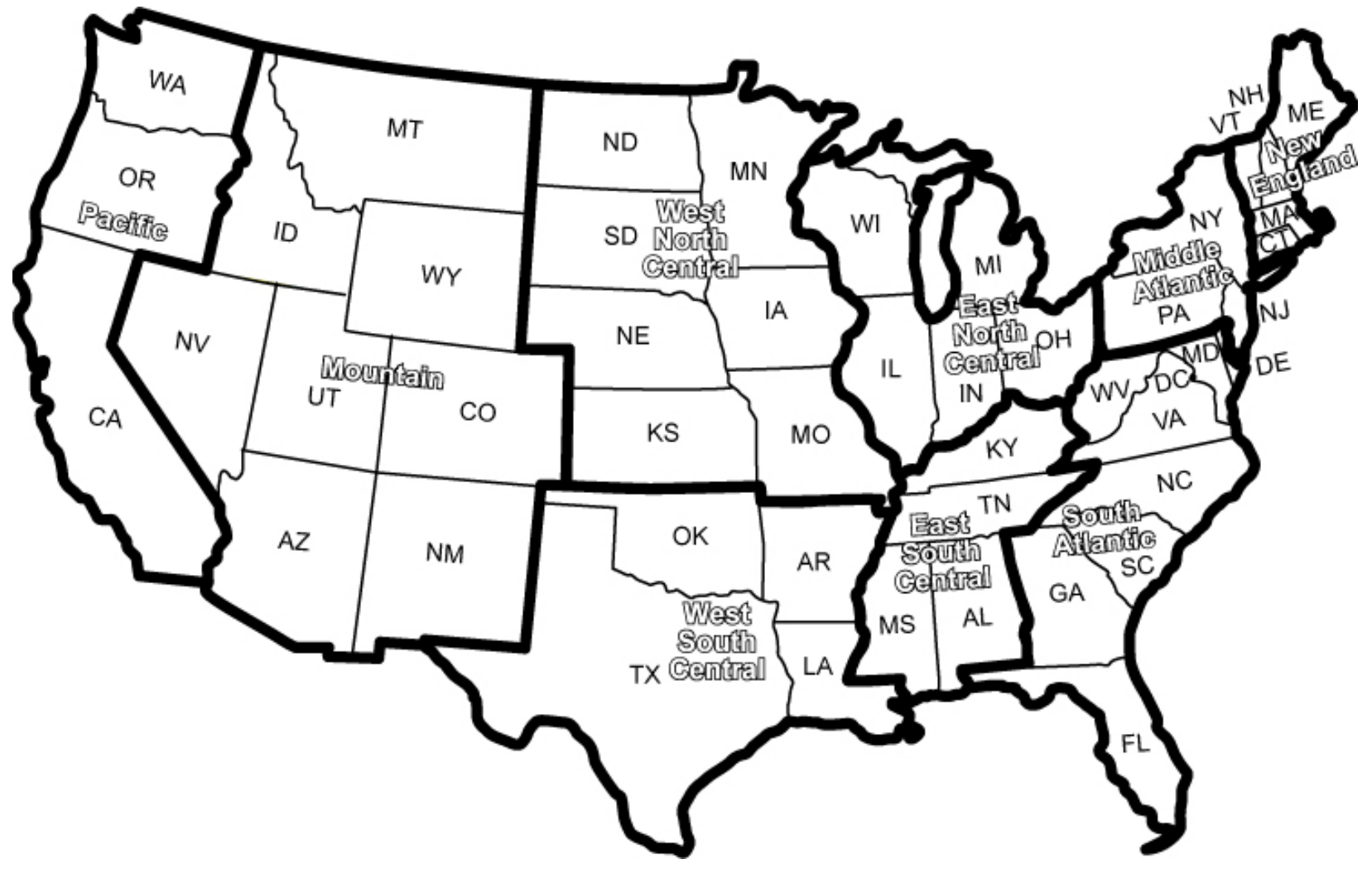

Figure 4-9 U.S. Census Bureau divisions

Results were sorted and weighted among all the buildings in each census division. Table 4-6 shows the fraction of floor area that can reach the ZEB goal for different census divisions and scenarios. Table 4-7 and Table 4-8 show how net site energy varies for the census divisions and scenarios.

The results show that the Mountain, West South Central, Pacific, and East South Central census divisions have the best prospects for achieving the ZEB goal. The worst prospects are for New England and Middle Atlantic. The lowest EUI census divisions in the Base context are Pacific, West South Central, and Mountain. In the ZEB context, the lowest EUI census divisions are Mountain, West South Central, Pacific, and East South Central. 
Table 4-6

Percentage of Floor Area Able to Reach ZEB by Census Division

\begin{tabular}{|c|c|c|c|c|c|c|c|c|c|c|}
\hline $\begin{array}{l}\text { Climate } \\
\text { Zone }\end{array}$ & $\begin{array}{l}\text { Num } \\
\text { model }\end{array}$ & $\begin{array}{c}\text { Base w/ } \\
\text { PV }\end{array}$ & $\begin{array}{l}\text { Max } \\
\text { Tech }\end{array}$ & $\begin{array}{l}\text { Max Tech } \\
\text { Base LPD }\end{array}$ & $\begin{array}{c}\text { Max Tech } \\
\text { No } \\
\text { Daylight }\end{array}$ & $\begin{array}{c}\text { Max Tech } \\
\text { Base } \\
\text { Windows }\end{array}$ & $\begin{array}{c}\text { Max Tech } \\
\text { Base } \\
\text { Envelope }\end{array}$ & $\begin{array}{c}\text { Max Tech } \\
\text { Base } \\
\text { HVAC }\end{array}$ & $\begin{array}{c}\text { Max Tech } \\
\text { Passive } \\
\text { Solar }\end{array}$ & $\begin{array}{c}\text { Max Tech } \\
\text { High } \\
\text { Appliance }\end{array}$ \\
\hline All & 4,820 & $20 \%$ & $47 \%$ & $42 \%$ & $47 \%$ & $44 \%$ & $35 \%$ & $41 \%$ & $47 \%$ & $50 \%$ \\
\hline $\begin{array}{l}1 \text { New } \\
\text { England }\end{array}$ & 195 & $4 \%$ & $24 \%$ & $24 \%$ & $26 \%$ & $21 \%$ & $13 \%$ & $17 \%$ & $24 \%$ & $26 \%$ \\
\hline $\begin{array}{l}2 \text { Middle } \\
\text { Atlantic }\end{array}$ & 641 & $7 \%$ & $34 \%$ & $29 \%$ & $34 \%$ & $29 \%$ & $22 \%$ & $28 \%$ & $33 \%$ & $36 \%$ \\
\hline $\begin{array}{c}3 \text { East North } \\
\text { Central }\end{array}$ & 860 & $10 \%$ & $43 \%$ & $39 \%$ & $43 \%$ & $37 \%$ & $22 \%$ & $33 \%$ & $43 \%$ & $44 \%$ \\
\hline $\begin{array}{l}4 \text { West } \\
\text { North } \\
\text { Central }\end{array}$ & 452 & $7 \%$ & $45 \%$ & $42 \%$ & $45 \%$ & $39 \%$ & $26 \%$ & $34 \%$ & $44 \%$ & $49 \%$ \\
\hline $\begin{array}{l}5 \text { South } \\
\text { Atlantic }\end{array}$ & 912 & $27 \%$ & $51 \%$ & $45 \%$ & $50 \%$ & $48 \%$ & $42 \%$ & $48 \%$ & $52 \%$ & $55 \%$ \\
\hline $\begin{array}{l}6 \text { East } \\
\text { South } \\
\text { Central }\end{array}$ & 279 & $21 \%$ & $52 \%$ & $45 \%$ & $52 \%$ & $48 \%$ & $38 \%$ & $44 \%$ & $52 \%$ & $57 \%$ \\
\hline $\begin{array}{l}7 \text { West } \\
\text { South } \\
\text { Central }\end{array}$ & 579 & $43 \%$ & $60 \%$ & $56 \%$ & $60 \%$ & $59 \%$ & $54 \%$ & $59 \%$ & $61 \%$ & $63 \%$ \\
\hline 8 Mountain & 305 & $27 \%$ & $62 \%$ & $53 \%$ & $61 \%$ & $58 \%$ & $45 \%$ & $51 \%$ & $62 \%$ & $68 \%$ \\
\hline 9 Pacific & 597 & $30 \%$ & $53 \%$ & $48 \%$ & $52 \%$ & $52 \%$ & $48 \%$ & $50 \%$ & $53 \%$ & $54 \%$ \\
\hline
\end{tabular}


Table 4-7 Net Site EUI for Various Scenarios by Census Division:

IP Units (kBtu/ $\left.\mathrm{ft}^{2} \cdot \mathrm{yr}\right)$

\begin{tabular}{|c|c|c|c|c|c|c|c|c|c|c|c|}
\hline $\begin{array}{c}\text { Climate } \\
\text { Zone }\end{array}$ & $\begin{array}{l}\text { Num } \\
\text { model }\end{array}$ & Base & $\begin{array}{c}\text { Base wl } \\
\text { PV }\end{array}$ & $\begin{array}{l}\text { Max } \\
\text { Tech }\end{array}$ & $\begin{array}{l}\text { Max } \\
\text { Tech } \\
\text { Base } \\
\text { LPD }\end{array}$ & $\begin{array}{c}\text { Max } \\
\text { Tech No } \\
\text { Daylight }\end{array}$ & $\begin{array}{l}\text { Max Tech } \\
\text { Base } \\
\text { Windows }\end{array}$ & $\begin{array}{l}\text { Max Tech } \\
\text { Base } \\
\text { Envelope }\end{array}$ & $\begin{array}{c}\text { Max Tech } \\
\text { Base } \\
\text { HVAC }\end{array}$ & $\begin{array}{l}\text { Max Tech } \\
\text { Passive } \\
\text { Solar }\end{array}$ & $\begin{array}{c}\text { Max Tech } \\
\text { High } \\
\text { Appliance }\end{array}$ \\
\hline All & 4,820 & 70.7 & 42.2 & 12.2 & 17.6 & 13.0 & 15.7 & 20.2 & 17.3 & 11.9 & 7.3 \\
\hline $\begin{array}{l}1 \mathrm{New} \\
\text { England }\end{array}$ & 195 & 84.4 & 65.7 & 31.0 & 35.2 & 31.5 & 36.9 & 41.6 & 36.7 & 31.2 & 24.5 \\
\hline $\begin{array}{l}2 \text { Middle } \\
\text { Atlantic }\end{array}$ & 641 & 68.5 & 48.5 & 16.5 & 22.5 & 17.4 & 21.3 & 24.9 & 22.0 & 16.5 & 12.4 \\
\hline $\begin{array}{l}3 \text { East } \\
\text { North } \\
\text { Central }\end{array}$ & 860 & 71.3 & 47.2 & 14.4 & 19.0 & 14.8 & 18.9 & 24.0 & 20.5 & 14.4 & 10.2 \\
\hline $\begin{array}{l}4 \text { West } \\
\text { North } \\
\text { Central }\end{array}$ & 452 & 81.8 & 52.2 & 12.5 & 16.5 & 12.9 & 17.1 & 25.9 & 21.1 & 12.9 & 8.1 \\
\hline $\begin{array}{l}5 \text { South } \\
\text { Atlantic }\end{array}$ & 912 & 75.3 & 43.7 & 14.8 & 21.6 & 16.0 & 17.5 & 21.3 & 19.6 & 14.3 & 8.6 \\
\hline $\begin{array}{l}6 \text { East } \\
\text { South } \\
\text { Central }\end{array}$ & 279 & 72.6 & 40.8 & 9.6 & 15.9 & 10.7 & 12.9 & 18.2 & 14.5 & 9.3 & 4.8 \\
\hline $\begin{array}{l}7 \text { West } \\
\text { South } \\
\text { Central }\end{array}$ & 579 & 63.7 & 27.3 & 2.7 & 8.1 & 3.5 & 4.9 & 9.0 & 6.0 & 2.3 & -2.0 \\
\hline $\begin{array}{c}8 \\
\text { Mountain }\end{array}$ & 305 & 63.9 & 27.3 & -3.2 & 2.2 & -2.1 & -0.3 & 5.2 & 2.8 & -3.2 & -6.7 \\
\hline 9 Pacific & 597 & 61.9 & 30.9 & 9.6 & 14.9 & 11.0 & 11.5 & 13.5 & 11.8 & 8.8 & 4.0 \\
\hline
\end{tabular}


Table 4-8 Net Site EUI for Various Scenarios by Census Division:

SI Units $\left(\mathrm{MJ} / \mathrm{m}^{2} \cdot \mathrm{yr}\right)$

\begin{tabular}{|c|c|c|c|c|c|c|c|c|c|c|c|}
\hline $\begin{array}{c}\text { Climate } \\
\text { Zone }\end{array}$ & $\begin{array}{l}\text { Num } \\
\text { model }\end{array}$ & Base & $\begin{array}{c}\text { Base w/ } \\
\text { PV }\end{array}$ & $\begin{array}{l}\text { Max } \\
\text { Tech }\end{array}$ & $\begin{array}{l}\text { Max } \\
\text { Tech } \\
\text { Base } \\
\text { LPD }\end{array}$ & $\begin{array}{c}\text { Max } \\
\text { Tech No } \\
\text { Daylight }\end{array}$ & $\begin{array}{c}\text { Max Tech } \\
\text { Base } \\
\text { Windows }\end{array}$ & $\begin{array}{l}\text { Max Tech } \\
\text { Base } \\
\text { Envelope }\end{array}$ & $\begin{array}{c}\text { Max Tech } \\
\text { Base } \\
\text { HVAC }\end{array}$ & $\begin{array}{c}\text { Max Tech } \\
\text { Passive } \\
\text { Solar }\end{array}$ & $\begin{array}{c}\text { Max Tech } \\
\text { High } \\
\text { Appliance }\end{array}$ \\
\hline All & 4,820 & 804 & 480 & 138 & 200 & 148 & 178 & 229 & 196 & 136 & 83 \\
\hline $\begin{array}{l}1 \mathrm{New} \\
\text { England }\end{array}$ & 195 & 959 & 746 & 352 & 400 & 358 & 419 & 473 & 417 & 355 & 279 \\
\hline $\begin{array}{l}2 \text { Middle } \\
\text { Atlantic }\end{array}$ & 641 & 778 & 551 & 188 & 255 & 198 & 242 & 284 & 250 & 188 & 141 \\
\hline $\begin{array}{l}3 \text { East } \\
\text { North } \\
\text { Central }\end{array}$ & 860 & 810 & 536 & 163 & 216 & 169 & 214 & 273 & 233 & 164 & 116 \\
\hline $\begin{array}{l}4 \text { West } \\
\text { North } \\
\text { Central }\end{array}$ & 452 & 930 & 594 & 142 & 187 & 147 & 194 & 294 & 240 & 146 & 92 \\
\hline $\begin{array}{l}5 \text { South } \\
\text { Atlantic }\end{array}$ & 912 & 856 & 497 & 168 & 245 & 182 & 199 & 242 & 223 & 162 & 98 \\
\hline $\begin{array}{l}6 \text { East } \\
\text { South } \\
\text { Central }\end{array}$ & 279 & 825 & 464 & 110 & 180 & 121 & 146 & 207 & 165 & 105 & 54 \\
\hline $\begin{array}{l}7 \text { West } \\
\text { South } \\
\text { Central }\end{array}$ & 579 & 724 & 310 & 30 & 92 & 39 & 56 & 102 & 69 & 26 & -22 \\
\hline $\begin{array}{c}8 \\
\text { Mountain }\end{array}$ & 305 & 726 & 311 & -36 & 25 & -24 & -4 & 59 & 31 & -36 & -76 \\
\hline 9 Pacific & 597 & 704 & 351 & 109 & 169 & 125 & 130 & 154 & 134 & 100 & 45 \\
\hline
\end{tabular}




\subsubsection{Solar resource}

Location also influences the amount of on-site generation from PV panels and the building's ability to reach ZEB. The energy produced by solar can be expressed as a production intensity that is normalized by the overall building floor area. Figure 4-10 shows the results for the part of sector floor area that could reach ZEB for different levels of solar production intensity. The plot suggests the relationship between improving solar production (e.g. by increased efficiency or area) and the ability of commercial sector buildings to reach the ZEB goal. Solar production intensity is expressed for total floor area of the building rather than for area available for solar collectors. Solar electric generation is modeled as $50 \%$ of available roof area with $20 \%$ collection efficiency and $95 \%$ DC to AC conversion.

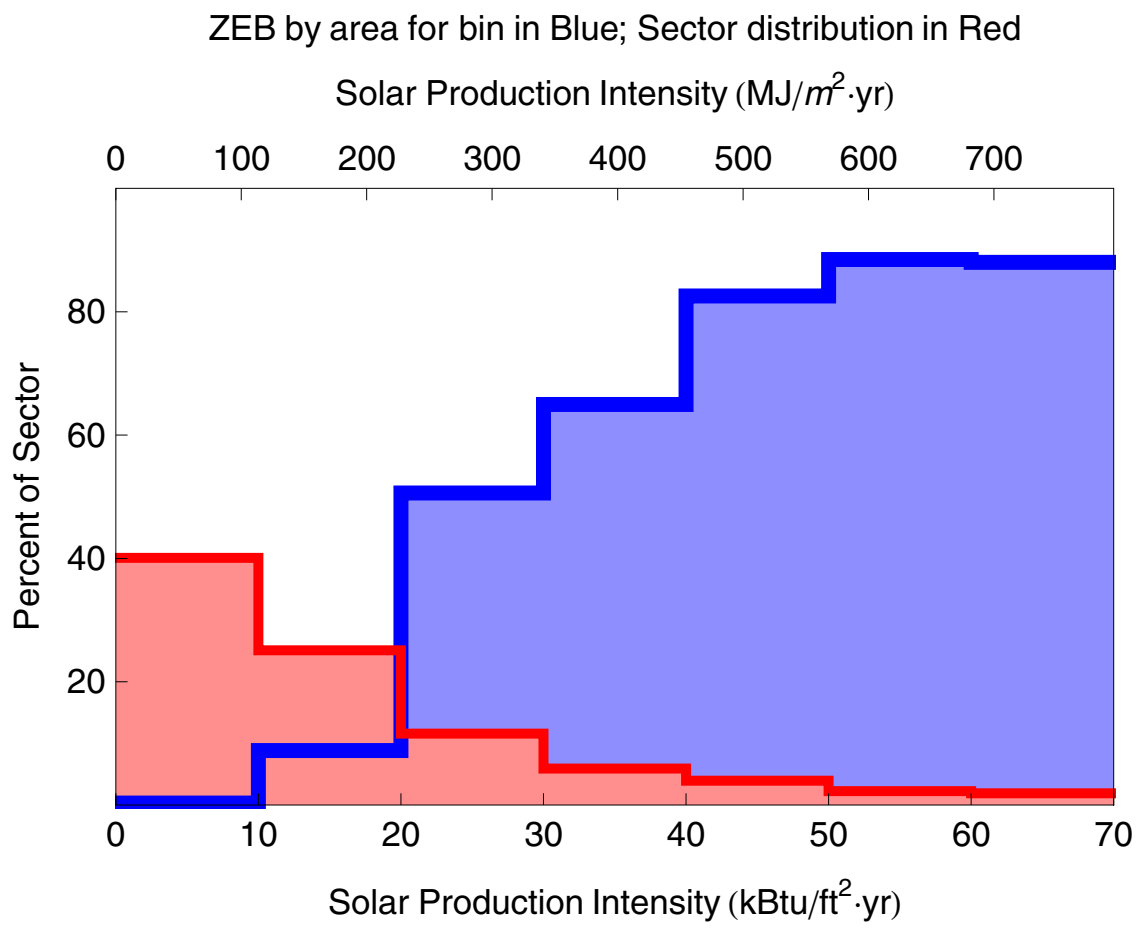

Figure 4-10 Percentage of floor area that can reach ZEB for various solar production intensities: Max Tech scenario

\subsubsection{Subsector Analysis}

An important underlying purpose of assessing the sector opportunities for ZEB is to help focus research program development. NREL analyzed commercial building subsectors to help identify which parts of the sector warrant the most attention. Various criteria could be applied when the study's results are analyzed to determine the most important subsectors. The two basic criteria included here are (1) the quantity of floor area with the potential for meeting the ZEB goal and (2) the sector-wide energy savings that could be achieved through ZEB technologies and practices.

\subsubsection{ZEB goal}

The ZEB goal can be easier or harder to achieve depending on the PBAs. Focusing ZEB research efforts on buildings that can most easily reach the goal leads to a higher likelihood of success. Selecting the easiest candidates may make sense because early successes might help to accelerate wide adoption of the ZEB concept by capturing the attention of decision makers. Figure 4-11 shows an analysis of the entire sector, including the percentage of floor area that can reach ZEB, which varies by subsector under the Max Tech scenario. The figure illustrates that nonrefrigerated warehouses will, on the whole, most easily 
reach the ZEB goal. Combining these findings with recommendations from Reed et al. (2004) suggests that the easiest targets should be national organizations with influence over large numbers of warehouses.

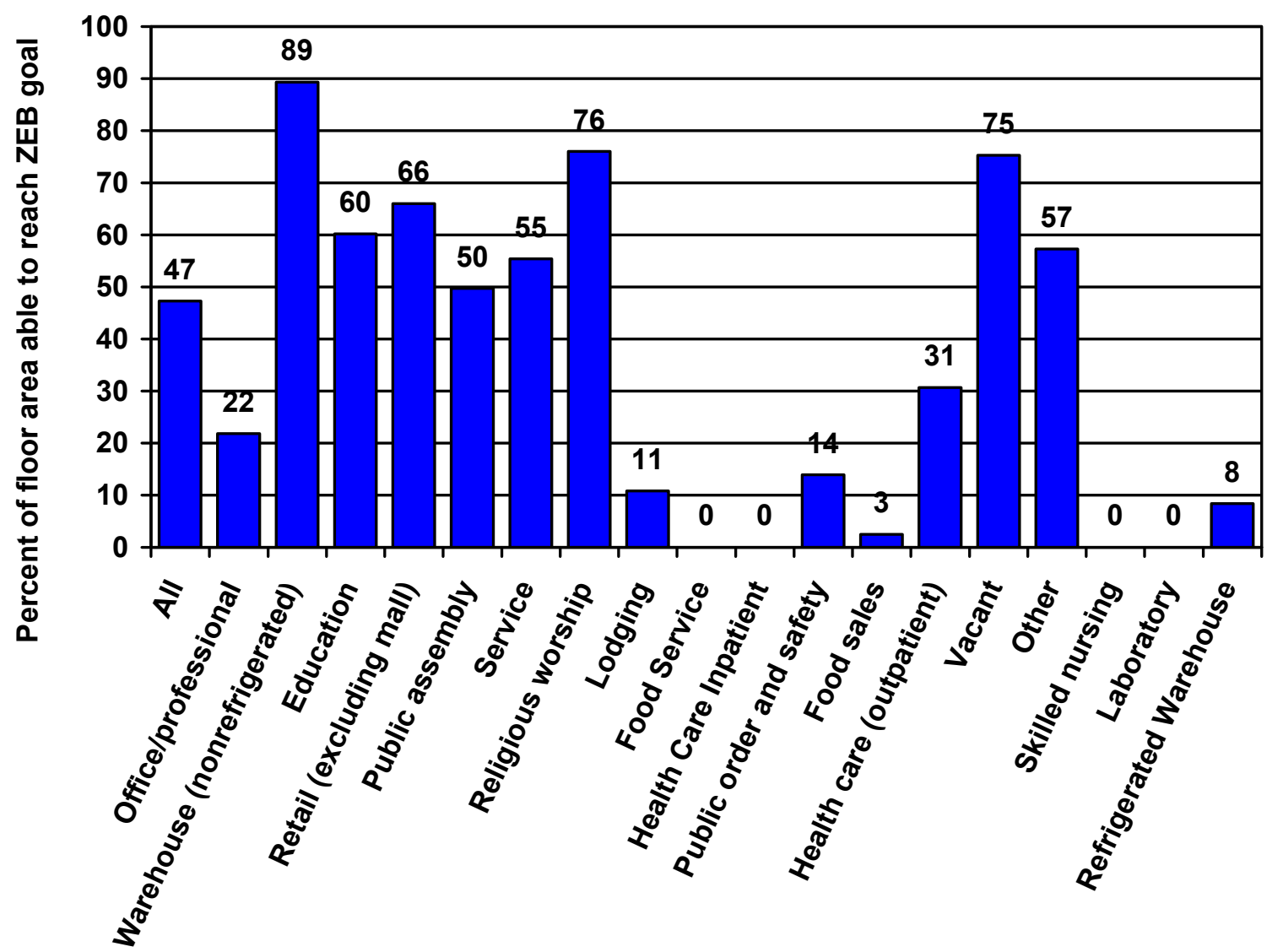

Subsector

Figure 4-11 Percentage of floor area that can reach ZEB goal: Max Tech scenario

\subsubsection{Energy reduction goal}

The goal of reducing the sector's impact on the national energy system leads to different criteria for where to focus research efforts. Because some subsectors are much larger and more energy intensive than others, subsector analysis based on the goal of reducing energy considers the magnitude of the reduction in net site EUI and how this reduction is amplified by the total floor area for that sector. These results show that the most important subsectors for reducing the sector's impact are retail spaces, offices, warehouses, and educational buildings. Figure 4-12 shows the level of savings in terms of the reduction in net site EUI by subsector. These data show somewhat more uniform reductions. The largest energy reduction potentials are in relatively high intensity subsectors, such as food sales, food service, service, and retail, which may provide greater economic benefit making them preferred targets for ZEB research efforts. 


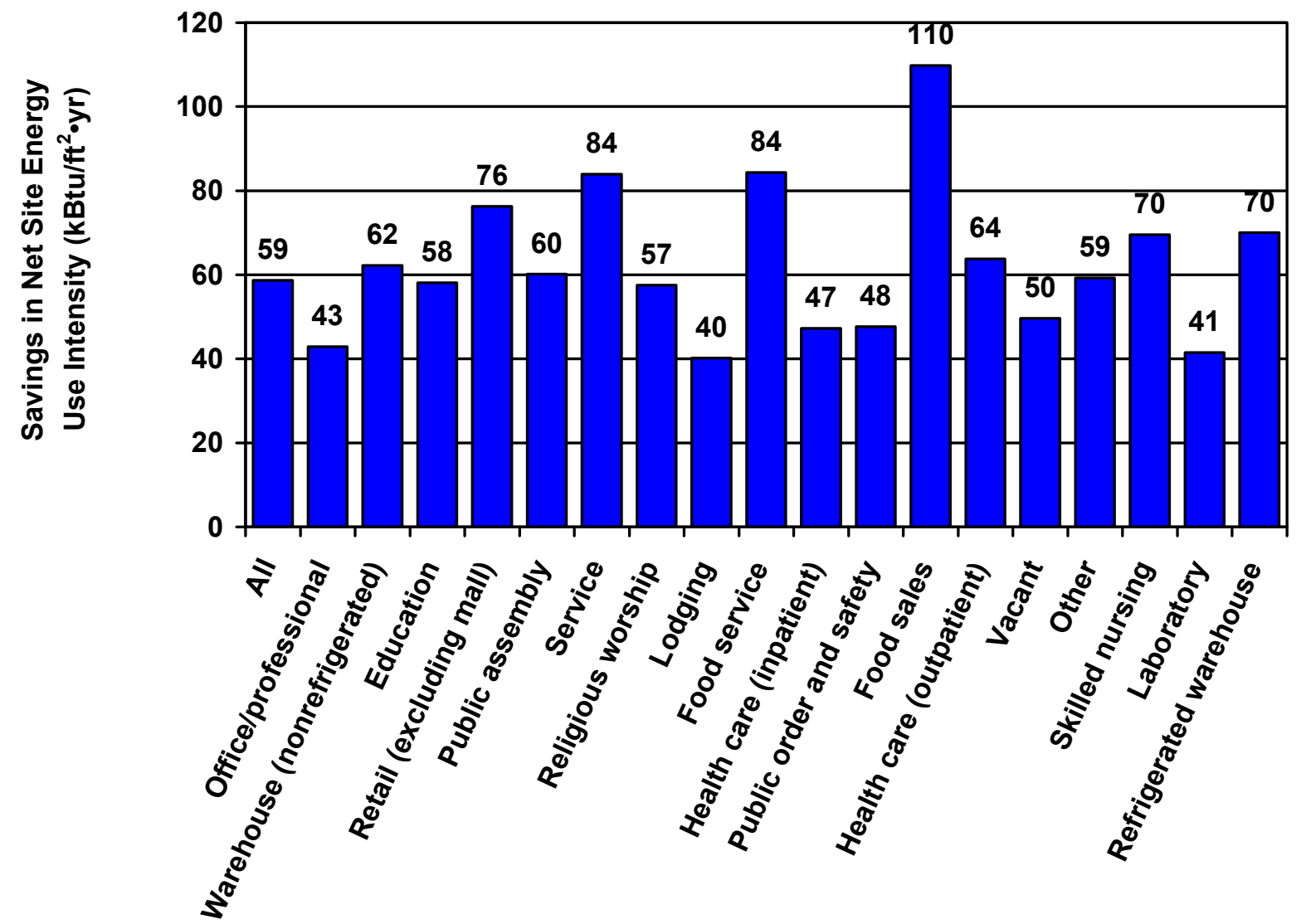

Subsector

Figure 4-12 Net site EUI savings for Max Tech scenario by subsector: IP units

Figure 4-13 shows the aggregated savings in site (delivered) energy that could technically be achieved in various subsectors. These data show the impact of total floor area on energy reduction. The aggregated savings level for warehouses is similar to what is possible in educational buildings, and both are slightly larger than the office/professional subsector.

The subsector analyses presented in Figure 4-11, Figure 4-12, and Figure 4-13 are summarized by listing the ordinal rankings in Table 4-9. Although offices have historically received the most research attention, these results show clearly that nonrefrigerated warehouses constitute an important subsector because they are a common type building and are the most likely to reach the ZEB goal and offer the highest total savings opportunity.

Mean values for net EUI values for the Base scenario are provided in Table 4-10 and Table 4-12 by both subsector and climate zone. Table 4-11 and Table 4-13 list the net EUI values for the Max Tech scenario. The gray boxes are where there are no models because the 2003 CBECS sample did not include any buildings in a particular category. The number of models and samples for each category are listed in Table 4-14. 


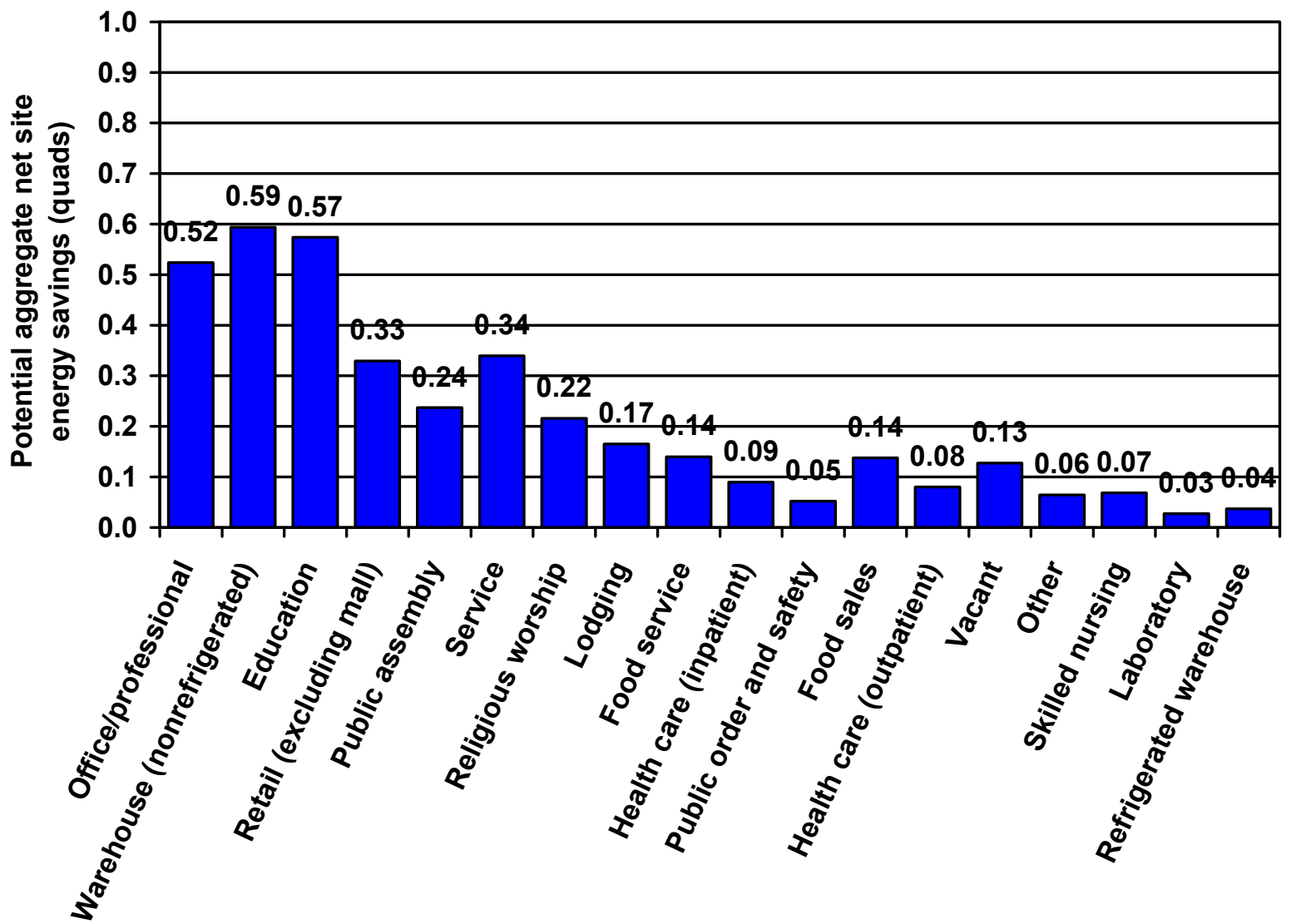

\section{Subsector}

Figure 4-13 Aggregated potential net site energy savings from Max Tech technologies and practices 
Table 4-9 Relative Ranking of Subsectors by Energy Performance Opportunities

\begin{tabular}{|l|c|c|c|}
\hline \multicolumn{1}{c|}{$\begin{array}{c}\text { Subsector } \\
\text { (PBA) }\end{array}$} & $\begin{array}{c}\text { Rank by } \\
\text { Aggregate } \\
\text { Energy Savings }\end{array}$ & $\begin{array}{c}\text { Rank by } \\
\text { Fraction That } \\
\text { Can Meet ZEB }\end{array}$ & $\begin{array}{c}\text { Rank by EUI } \\
\text { Savings }\end{array}$ \\
\hline \hline Office/professional & 3 & 10 & 16 \\
\hline Nonrefrigerated warehouse & 1 & 1 & 8 \\
\hline Education & 2 & 5 & 11 \\
\hline Retail (excluding mall) & 5 & 4 & 4 \\
\hline Public assembly & 6 & 8 & 9 \\
\hline Service & 4 & 6 & 3 \\
\hline Religious worship & 7 & 3 & 12 \\
\hline Lodging & 8 & 12 & 18 \\
\hline Food service & 9 & 17 & 2 \\
\hline Health care (inpatient) & 11 & 16 & 15 \\
\hline Public order and safety & 15 & 11 & 14 \\
\hline Food sales & 14 & 14 & 1 \\
\hline Health care (outpatient) & 12 & 9 & 7 \\
\hline Vacant & 10 & 2 & 13 \\
\hline Other & 14 & 7 & 10 \\
\hline Skilled nursing & 13 & 15 & 6 \\
\hline Laboratory & 16 & 18 & 17 \\
\hline Refrigerated warehouse & 17 & 12 & 5 \\
\hline
\end{tabular}


Table 4-10 Base Scenario EUI by Subsectors and Climate Zones

IP Units (kBtu/ft ${ }^{2} \cdot$ yr)

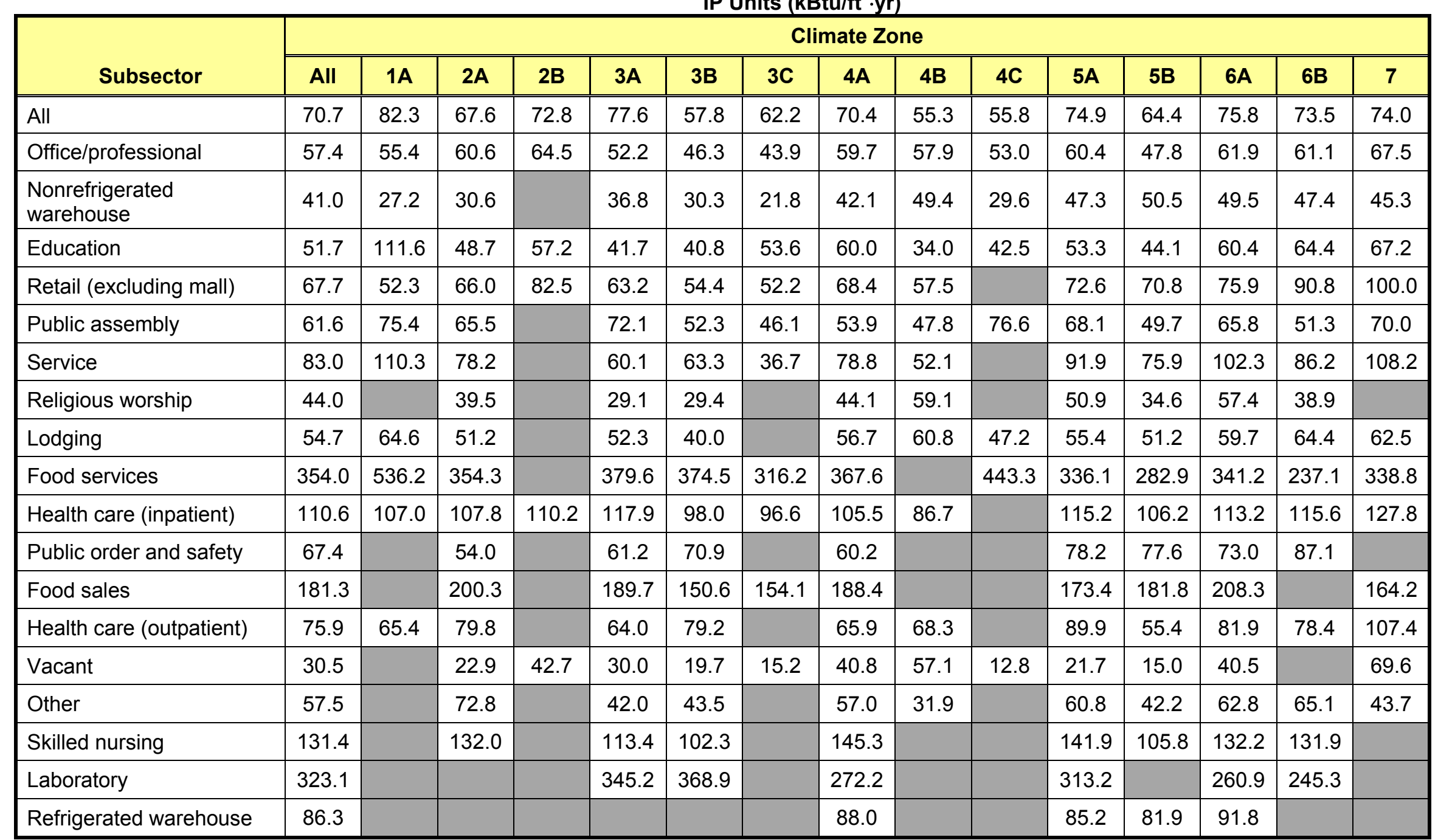

Note: There are no CBECS buildings in climate zone 8. 
Table 4-11 Max Tech Scenario EUI by Subsectors and Climate Zones:

IP Units (kBtu/ft $\left.{ }^{2} \cdot \mathrm{yr}\right)$

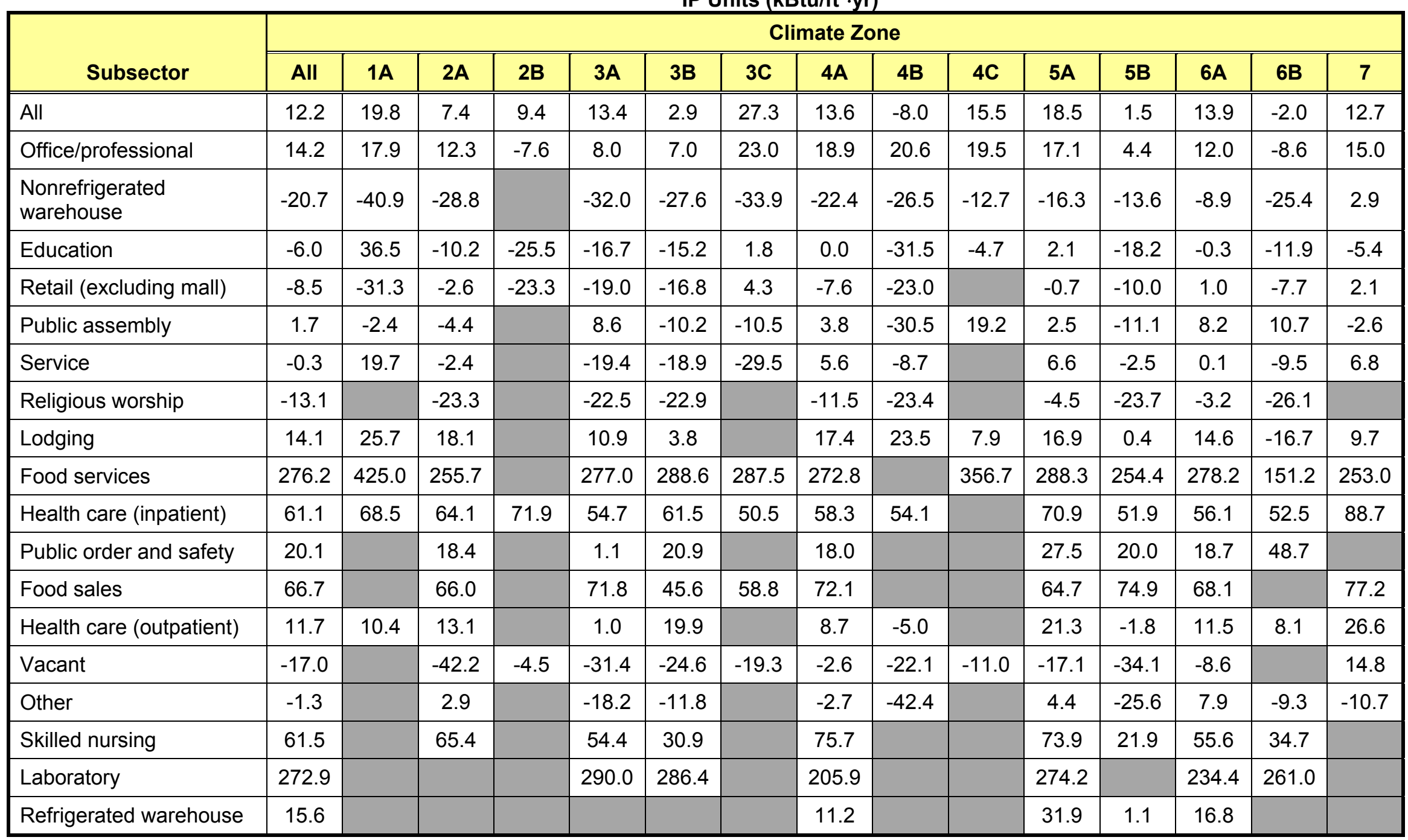


Table 4-12 Base Scenario EUI by Subsectors and Climate Zones

SI Units $\left(\mathrm{MJ} / \mathrm{m}^{2} \cdot \mathrm{yr}\right)$

\begin{tabular}{|c|c|c|c|c|c|c|c|c|c|c|c|c|c|c|c|}
\hline Subsector & \multicolumn{15}{|c|}{ Climate Zone } \\
\hline All & 803 & 935 & 768 & 827 & 882 & 657 & 707 & 800 & 628 & 634 & 851 & 732 & 861 & 835 & 841 \\
\hline $\begin{array}{l}\text { Nonrefrigerated } \\
\text { warehouse }\end{array}$ & 466 & 309 & 348 & & 418 & 344 & 248 & 478 & 561 & 336 & 538 & 574 & 563 & 539 & 515 \\
\hline Public assembly & 700 & 857 & 744 & & 819 & 594 & 524 & 613 & 543 & 870 & 774 & 565 & 748 & 583 & 795 \\
\hline Service & 943 & 1,253 & 889 & & 683 & 719 & 417 & 895 & 592 & & 1,044 & 863 & 1,163 & 980 & 1,230 \\
\hline Religious worship & 500 & & 449 & & 331 & 334 & & 501 & 672 & & 578 & 393 & 652 & 442 & \\
\hline Lodging & 622 & 734 & 582 & & 594 & 455 & & 644 & 691 & 536 & 630 & 582 & 678 & 732 & 710 \\
\hline Food sales & 2,060 & & 2,276 & & 2,156 & 1,711 & 1,751 & 2,141 & & & 1,970 & 2,066 & 2,367 & & 1,866 \\
\hline Health care (outpatient) & 863 & 743 & 907 & & 727 & 900 & & 749 & 776 & & 1,022 & 630 & 931 & 891 & 1,220 \\
\hline Vacant & 347 & & 260 & 485 & 341 & 224 & 173 & 464 & 649 & 145 & 247 & 170 & 460 & & 791 \\
\hline Other & 653 & & 827 & & 477 & 494 & & 648 & 363 & & 691 & 480 & 714 & 740 & 497 \\
\hline Skilled nursing & 1,493 & & 1,500 & & 1,289 & 1,163 & & 1,651 & & & 1,613 & 1,202 & 1,502 & 1,499 & \\
\hline Laboratory & 3,672 & & & & 3,923 & 4,192 & & 3,093 & & & 3,559 & & 2,965 & 2,788 & \\
\hline Refrigerated warehouse & 981 & & & & & & & 1,000 & & & 968 & 931 & 1,043 & & \\
\hline
\end{tabular}


Table 4-13 Max Tech Scenario EUI by Subsectors and Climate Zones:

SI Units $\left(\mathrm{MJ} / \mathrm{m}^{2} \cdot \mathrm{yr}\right)$

\begin{tabular}{|c|c|c|c|c|c|c|c|c|c|c|c|c|c|c|c|}
\hline Subsector & \multicolumn{15}{|c|}{ Climate Zone } \\
\hline All & 139 & 225 & 84 & 107 & 152 & 33 & 310 & 155 & -91 & 176 & 210 & 17 & 158 & -23 & 144 \\
\hline $\begin{array}{l}\text { Nonrefrigerated } \\
\text { warehouse }\end{array}$ & -235 & -465 & -327 & & -364 & -314 & -385 & -255 & -301 & -144 & -185 & -155 & -101 & -289 & 33 \\
\hline Public assembly & 19 & -27 & -50 & & 98 & -116 & -119 & 43 & -347 & 218 & 28 & -126 & 93 & 122 & -30 \\
\hline Service & -3 & 224 & -27 & & -220 & -215 & -335 & 64 & -99 & & 75 & -28 & 1 & -108 & 77 \\
\hline Religious worship & -149 & & -265 & & -256 & -260 & & -131 & -266 & & -51 & -269 & -36 & -297 & \\
\hline Lodging & 160 & 292 & 206 & & 124 & 43 & & 198 & 267 & 90 & 192 & 5 & 166 & -190 & 110 \\
\hline Food sales & 758 & & 750 & & 816 & 518 & 668 & 819 & & & 735 & 851 & 774 & & 877 \\
\hline Health care (outpatient) & 133 & 118 & 149 & & 11 & 226 & & 99 & -57 & & 242 & -20 & 131 & 92 & 302 \\
\hline Vacant & -193 & & -480 & -51 & -357 & -280 & -219 & -30 & -251 & -125 & -194 & -388 & -98 & & 168 \\
\hline Other & -15 & & 33 & & -207 & -134 & & -31 & -482 & & 50 & -291 & 90 & -106 & -122 \\
\hline Skilled nursing & 699 & & 743 & & 618 & 351 & & 860 & & & 840 & 249 & 632 & 394 & \\
\hline Laboratory & 3,101 & & & & 3,295 & 3,255 & & 2,340 & & & 3,116 & & 2,664 & 2,966 & \\
\hline Refrigerated warehouse & 177 & & & & & & & 127 & & & 363 & 13 & 191 & & \\
\hline
\end{tabular}


Table 4-14 Number of Models by Subsectors and Climate Zones

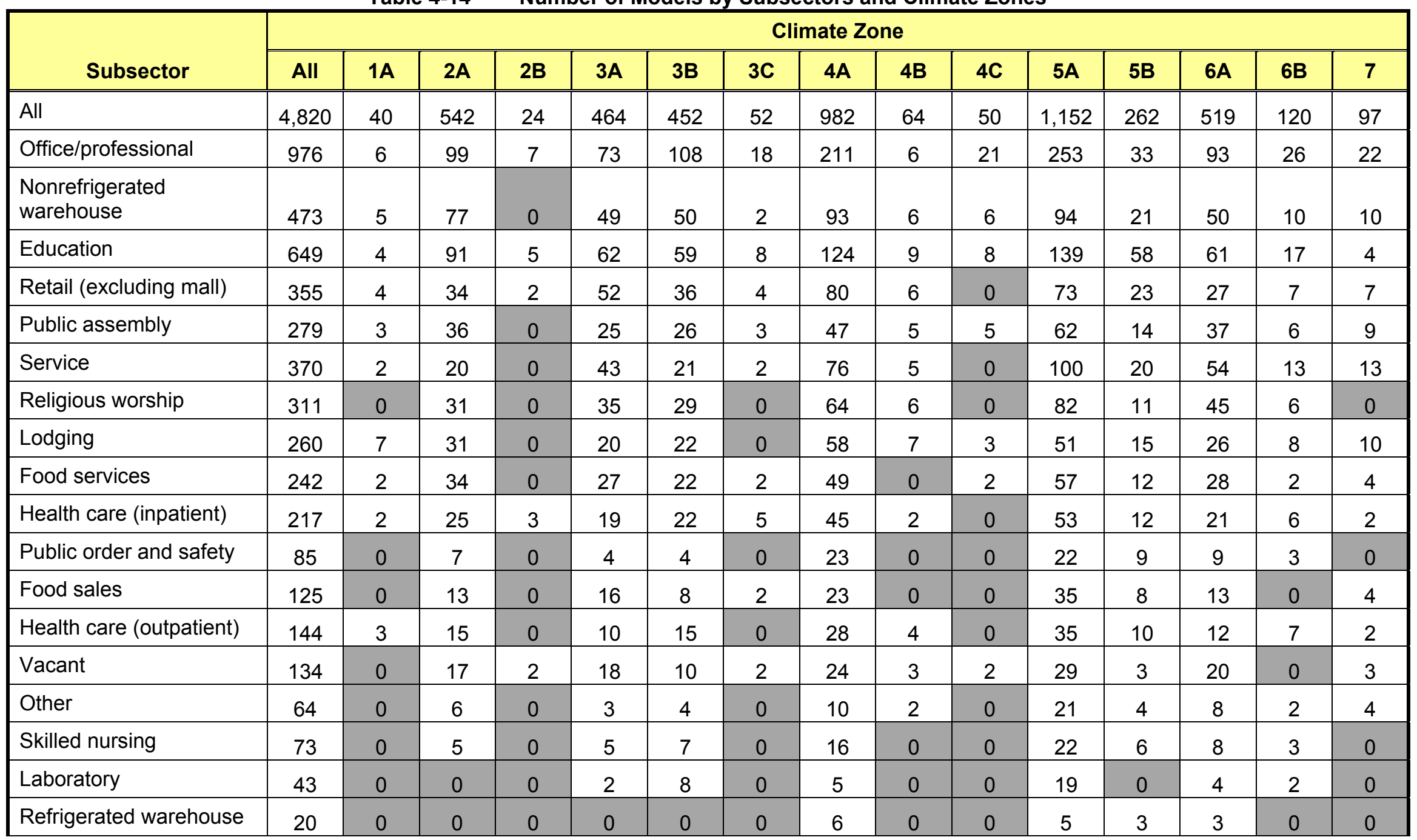




\subsection{Energy End Use Splits}

The simulation results can also be analyzed to reveal the impact by different end uses and fuel types.

Table 4-15 lists the end use results for the Base and Max Tech scenarios.

Table 4-15 Sector-Wide Average Site EUI by End Use for Various Scenarios

\begin{tabular}{|c|c|c|c|c|c|}
\hline \multirow{2}{*}{ End Use } & \multicolumn{2}{|c|}{ Base } & \multicolumn{2}{|c|}{ Max Tech } & \multirow{2}{*}{$\begin{array}{l}\text { Percent } \\
\text { Savings }\end{array}$} \\
\hline & $\left(\mathrm{kBtu} / \mathrm{ft}^{2} \cdot \mathrm{yr}\right)$ & $\left(\mathrm{MJ} / \mathrm{m}^{2} \cdot \mathrm{yr}\right)$ & $\left(\mathrm{kBtu} / \mathrm{ft}^{2} \cdot \mathrm{yr}\right)$ & $\left(\mathrm{MJ} / \mathrm{m}^{2} \cdot \mathrm{yr}\right)$ & \\
\hline Lights & 12.6 & 143 & 4.5 & 51 & $64 \%$ \\
\hline Cooling equipment & 9.1 & 103 & 5.2 & 59 & $43 \%$ \\
\hline Heating equipment & 17.5 & 199 & 5.2 & 59 & $70 \%$ \\
\hline Fans & 4.6 & 52 & 1.7 & 19 & $63 \%$ \\
\hline Pumps & 0.54 & 6 & 0.38 & 4 & $30 \%$ \\
\hline Plug/process electricity & 10.1 & 115 & 10.1 & 115 & $0 \%$ \\
\hline Process gas & 5.3 & 60 & 5.3 & 60 & $0 \%$ \\
\hline Refrigeration & 4.4 & 50 & 3.1 & 35 & $30 \%$ \\
\hline Total site & 70.7 & 803 & 40.3 & 458 & $43 \%$ \\
\hline PV production & 0.0 & 0 & 28.1 & 319 & $\mathrm{~N} / \mathrm{A}$ \\
\hline Net site & 70.7 & 803 & 12.2 & 139 & $83 \%$ \\
\hline
\end{tabular}

Figure 4-14 shows a Pareto chart for the distribution of the end uses in the Base scenario. Figure 4-15 shows the distribution for the Max Tech scenario. The efficiency improvements in the Max Tech scenario do not reduce process energy uses making these the largest portion of the energy consumption in ZEBs.

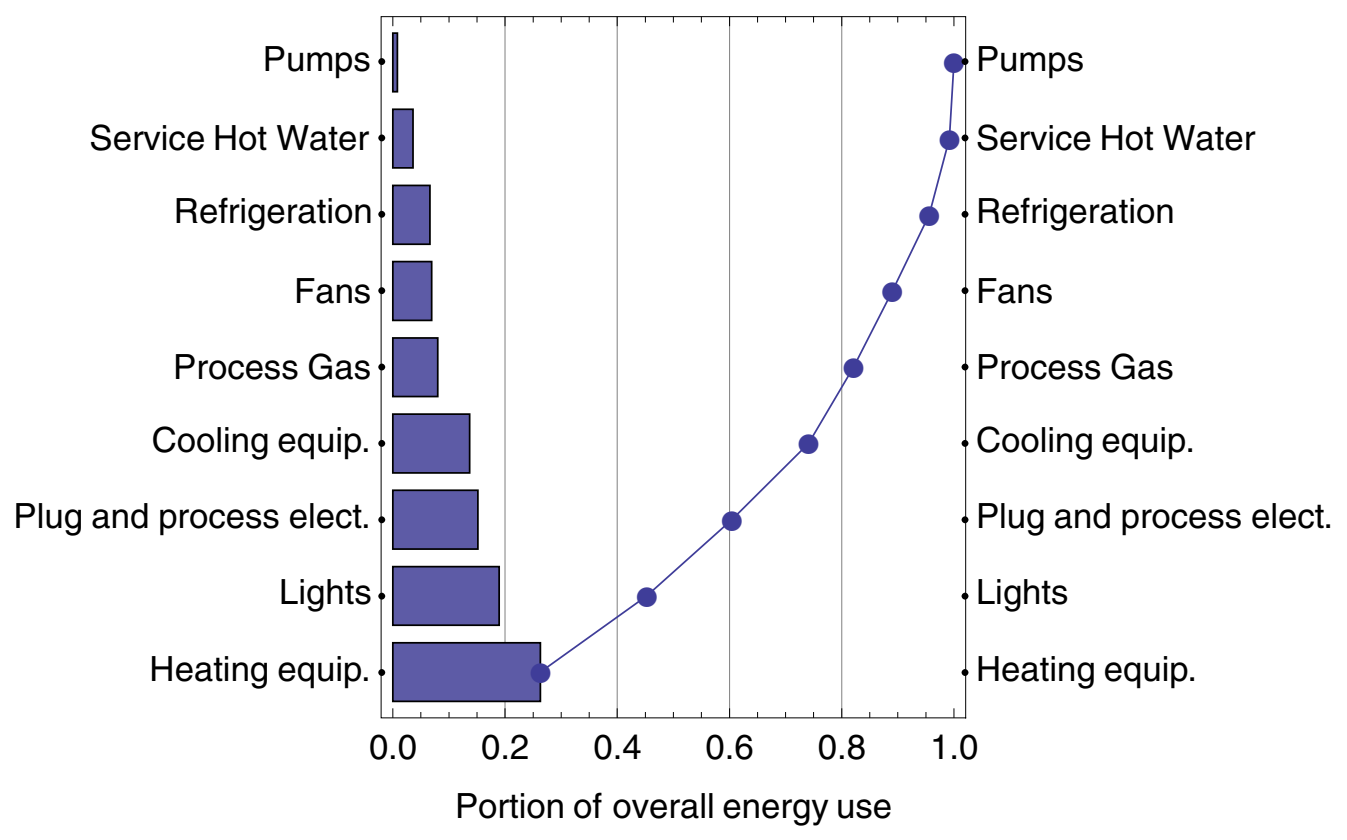

Figure 4-14 Site energy use (consumption) by end use for Base scenario 


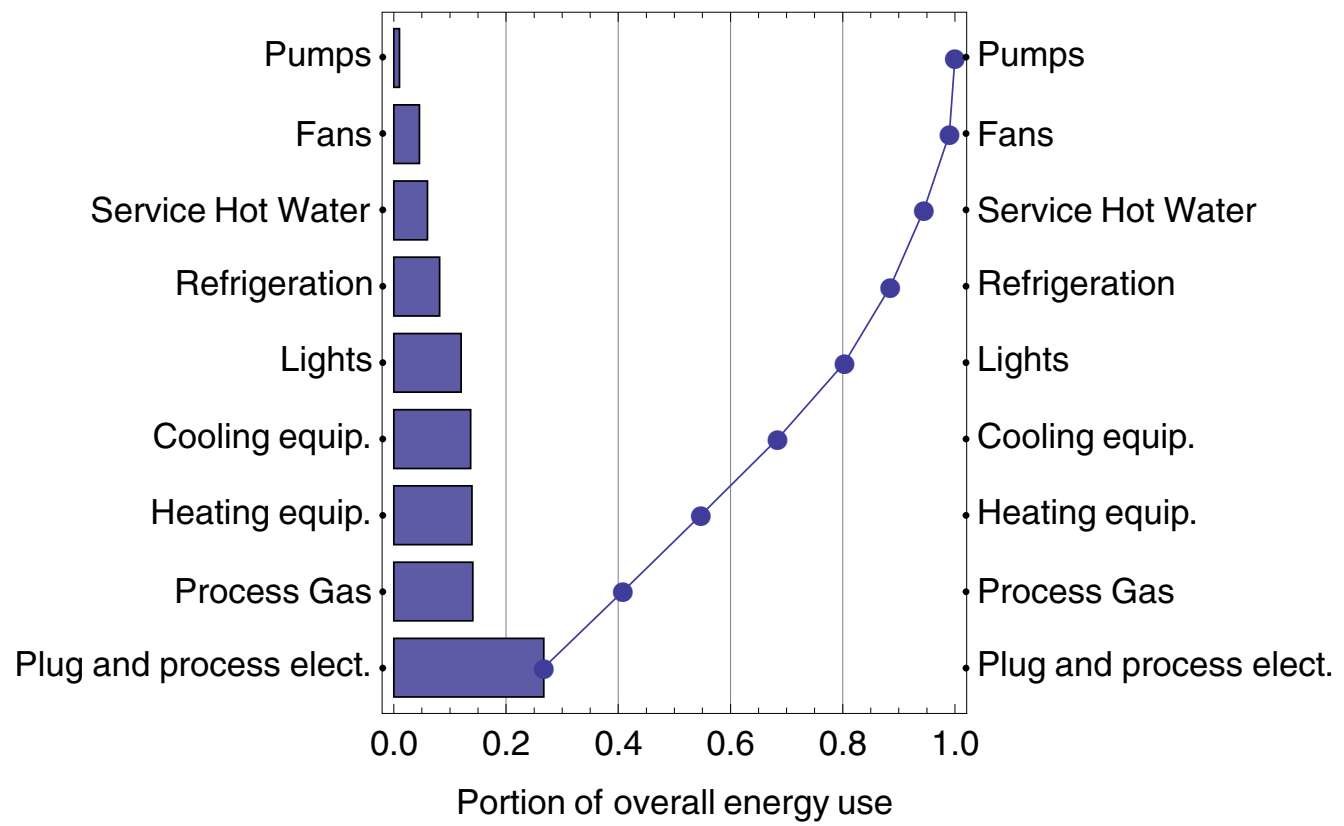

Figure 4-15 Site energy use (consumption) by end use for Max Tech scenario

\subsection{Technologies and Practices for Meeting the ZEB Goal}

Although the primary question being addressed in this study involves the overall attainability of the ZEB goal, the next questions center on what technologies and practices are important for achieving the goal. This section discusses the results of the study in the context of individual technologies and practices. The first subsection discusses the overall importance of efficiency in the context of net-zero energy buildings while subsequent subsections discuss individual technologies and practices.

\subsubsection{Efficiency versus Supply}

The study results support the intuitive idea that in pursuing the ZEB goal, energy efficiency must be included so on-site supply can more readily meet the reduced energy use.

Comparing the results of the Base w/PV scenario to those of Max Tech scenario shows that efficiency improvements make the ZEB goal much more attainable. Adding the aggressive rooftop PV systems from the Max Tech scenario to minimum-standard buildings of the Base scenario showed $20 \%$ of commercial floor area and $23 \%$ of commercial buildings could reach ZEB. But when efficiency measures are also added, two to three times more of the commercial sector can reach ZEB than could with only PV. From an energy savings point of view, the Max Tech PV systems can reduce site energy use in minimumstandard buildings by $40 \%$, on average; efficiency improvements can reduce site energy use by $33 \%$ to $48 \%$ for the Max Tech scenarios. This indicates that the amount of energy that can be saved by efficiency measures is comparable to the amount that can be generated by rooftop PV panels and that pursuing both is important for reaching the ZEB goal.

Another way to explore the importance of efficiency measures is to calculate the percent savings needed to meet the ZEB goal based on the available on-site production from PV power systems. For the sector as a whole, the results indicate that 59\% savings over 90.1-2004 is needed to reach the ZEB goal for the PV power systems modeled ( $20 \%$ efficient modules on one-half of the roof area). Results for the savings required in different subsectors are plotted in Figure 4-16. Offices need 67\%, warehouses 6\%, educational facilities $43 \%$, and retail needs $45 \%$ savings to reach ZEB. Very high levels of savings (greater than 90\%) would be needed to reach ZEB for high-intensity subsectors such as food service, inpatient health care, and laboratories. 


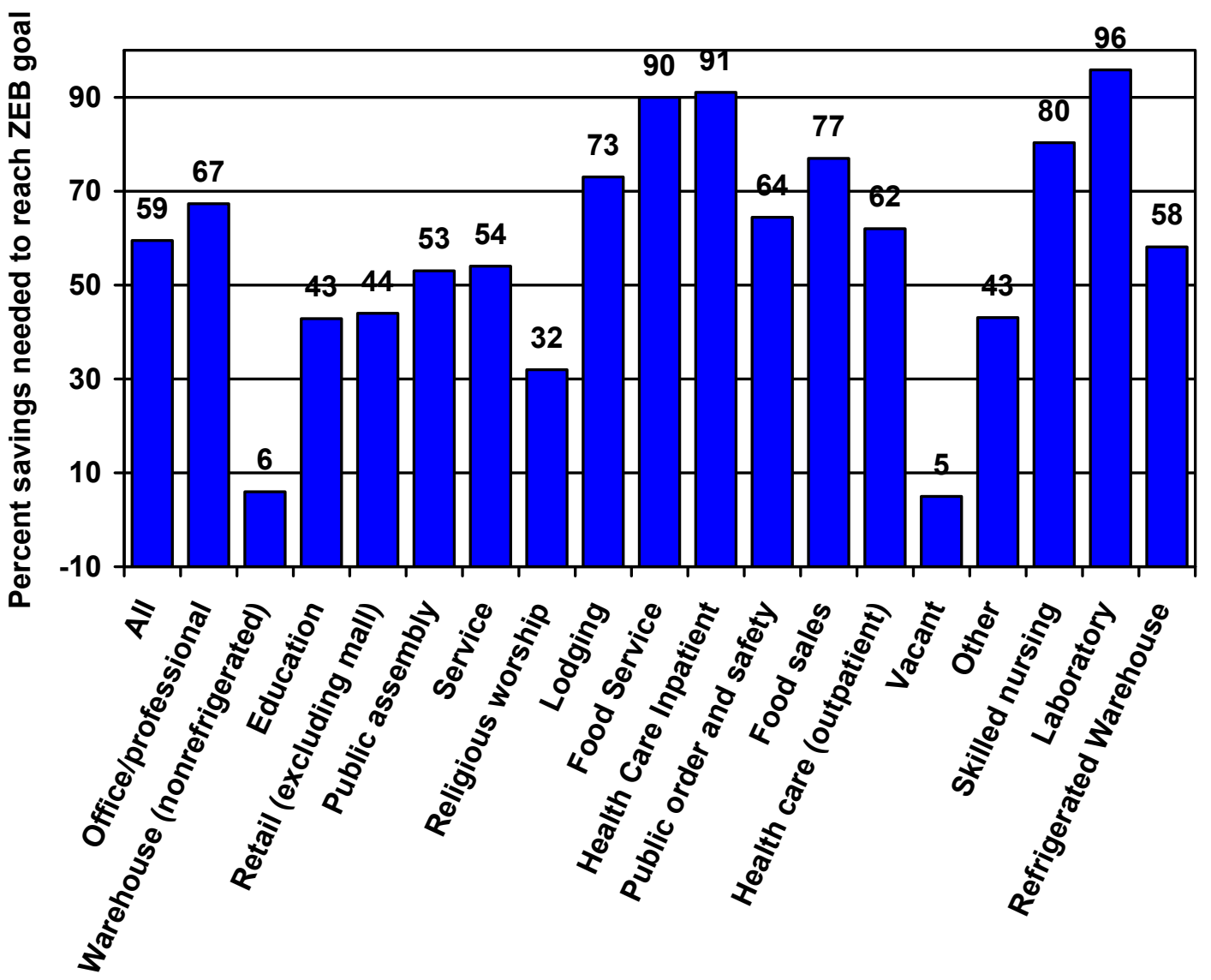

Subsector

Figure 4-16 Percent savings from efficiency needed to reach ZEB

\subsubsection{Lighting}

Scenarios to examine the technical potential for lighting equipment include Base $20 \%$ LPD, Base $50 \%$ LPD, Max Tech Base LPD, Max Tech 20\% LPD. Table 4-16 and Table 4-17 list the results for the entire commercial sector for these scenarios and compares them to the Base and Max Tech scenarios.

The modeling results for the Base 50\% LPD scenario show that if the BT goal for lighting equipment (reduce LPD by $50 \%$ ) is reached, whole-building EUIs can be lowered by $6.8 \mathrm{kBtu} / \mathrm{ft}^{2} \cdot \mathrm{yr}\left(77 \mathrm{MJ} / \mathrm{m}^{2} \cdot \mathrm{yr}\right.$ ) or $10 \%$ relative to Base. Lighting equipment improvements reduced cooling energy end uses by $13 \%$ and increased heating energy end use by $6 \%$. Whole-building energy reductions were found to equal the direct lighting energy savings plus and additional $10 \%$ of the direct lighting savings, accounting for reduced cooling offset with increased heating.

In the ZEB context, a 50\% LPD reduction results in EUIs that are $5.4 \mathrm{kBtu} / \mathrm{ft}^{2} \cdot \mathrm{yr}\left(61 \mathrm{MJ} / \mathrm{m}^{2} \cdot \mathrm{yr}\right)$, or $12 \%$, lower than for Base LPD and $2.2 \mathrm{kBtu} / \mathrm{ft}^{2} \cdot \mathrm{yr}\left(25 \mathrm{MJ} / \mathrm{m}^{2} \cdot \mathrm{yr}\right)$, or $7 \%$, lower than for a $20 \% \mathrm{LPD}$ reduction. If we assume that BT's research on solid-state lighting enables future LPD reductions of $50 \%$ compared to a $20 \% \mathrm{LPD}$ reduction, EUI reductions of $4.1 \mathrm{kBtu} / \mathrm{ft}^{2} \cdot \mathrm{yr}\left(47 \mathrm{MJ} / \mathrm{m}^{2} \cdot \mathrm{yr}\right)$ across the sector in the current context and $3.2 \mathrm{kBtu} / \mathrm{ft}^{2} \cdot \mathrm{yr}\left(36 \mathrm{MJ} / \mathrm{m}^{2} \cdot \mathrm{yr}\right)$ in the ZEB context would occur.

Figure 4-17 shows the PDF curves for the various scenarios related to lighting equipment. The 50\% LPD reductions show marked shifting of the distributions across broad portions of the sector. 
Table 4-16 Sector-Wide Average Use Intensity Metrics for Lighting Scenarios: IP units

\begin{tabular}{|c|c|c|c|c|c|c|c|c|c|c|}
\hline Use Intensity Metric & Base & $\begin{array}{c}\text { Base } \\
20 \% \\
\text { LPD }\end{array}$ & $\begin{array}{c}\text { Base } \\
20 \% \\
\text { LPD } \\
\text { Savings }\end{array}$ & $\begin{array}{l}\text { Base } \\
50 \% \\
\text { LPD }\end{array}$ & $\begin{array}{c}\text { Base } \\
50 \% \\
\text { LPD } \\
\text { Savings }\end{array}$ & $\begin{array}{l}\text { Max } \\
\text { Tech }\end{array}$ & $\begin{array}{l}\text { Max } \\
\text { Tech } \\
\text { Base } \\
\text { LPD }\end{array}$ & $\begin{array}{c}\text { Max } \\
\text { Tech } \\
\text { Base } \\
\text { LPD } \\
\text { Savings }\end{array}$ & $\begin{array}{l}\text { Max } \\
\text { Tech } \\
20 \% \\
\text { LPD }\end{array}$ & $\begin{array}{c}\text { Max } \\
\text { Tech } \\
20 \% \\
\text { LPD } \\
\text { Savings }\end{array}$ \\
\hline Total site $\left(\mathrm{kBtu} / \mathrm{ft}^{2} \cdot \mathrm{yr}\right)$ & 70.7 & 68.0 & $4 \%$ & 63.9 & $10 \%$ & 40.3 & 45.7 & $12 \%$ & 43.5 & $7 \%$ \\
\hline PV production $\left(\mathrm{kBtu} / \mathrm{ft}^{2} \cdot \mathrm{yr}\right)$ & 0.0 & 0.0 & $0 \%$ & 0.0 & $0 \%$ & 28.1 & 28.1 & $0 \%$ & 28.1 & $0 \%$ \\
\hline Net site $\left(\mathrm{kBtu} / \mathrm{ft}^{2} \cdot \mathrm{yr}\right)$ & 70.7 & 68.0 & $4 \%$ & 63.9 & $10 \%$ & 12.2 & 17.6 & $31 \%$ & 15.4 & $21 \%$ \\
\hline Lights $\left(\mathrm{kBtu} / \mathrm{ft}^{2} \cdot \mathrm{yr}\right)$ & 12.6 & 10.1 & $20 \%$ & 6.4 & $49 \%$ & 4.5 & 8.9 & $49 \%$ & 7.1 & $37 \%$ \\
\hline Cooling equipment (kBtu/ft $\left.{ }^{2} \cdot y r\right)$ & 9.1 & 8.6 & $5 \%$ & 7.9 & $13 \%$ & 5.2 & 5.9 & $12 \%$ & 5.6 & $7 \%$ \\
\hline Heating equipment $\left(\mathrm{kBtu} / \mathrm{ft}^{2} \cdot \mathrm{yr}\right)$ & 17.5 & 18.0 & $-3 \%$ & 18.6 & $-6 \%$ & 5.2 & 5.1 & $-2 \%$ & 5.1 & $-2 \%$ \\
\hline Fans $\left(\mathrm{kBtu} / \mathrm{ft}^{2} \cdot \mathrm{yr}\right)$ & 4.6 & 4.4 & $4 \%$ & 4.2 & $9 \%$ & 1.7 & 1.9 & $11 \%$ & 1.8 & $6 \%$ \\
\hline Pumps (kBtu/ft' $\left.{ }^{2} \cdot \mathrm{yr}\right)$ & 0.54 & 0.52 & $4 \%$ & 0.48 & $11 \%$ & 0.38 & 0.42 & $10 \%$ & 0.40 & $5 \%$ \\
\hline Plug and process electricity $\left(\mathrm{kBtu} / \mathrm{ft}^{2} \cdot \mathrm{yr}\right)$ & 10.1 & 10.1 & $0 \%$ & 10.1 & $0 \%$ & 10.1 & 10.1 & $0 \%$ & 10.1 & $0 \%$ \\
\hline Process gas $\left(\mathrm{kBtu} / \mathrm{ft}^{2} \cdot \mathrm{yr}\right)$ & 5.3 & 5.3 & $0 \%$ & 5.3 & $0 \%$ & 5.3 & 5.3 & $0 \%$ & 5.3 & $0 \%$ \\
\hline Refrigeration $\left(\mathrm{kBtu} / \mathrm{ft}^{2} \cdot \mathrm{yr}\right)$ & 4.4 & 4.4 & $0 \%$ & 4.4 & $0 \%$ & 3.1 & 3.1 & $0 \%$ & 3.1 & $0 \%$ \\
\hline Service water heating $\left(\mathrm{kBtu} / \mathrm{ft}^{2} \cdot \mathrm{yr}\right)$ & 2.5 & 2.5 & $0 \%$ & 2.5 & $0 \%$ & 2.3 & 2.3 & $0 \%$ & 2.3 & $0 \%$ \\
\hline Total site electricity $\left(\mathrm{kBtu} / \mathrm{ft}^{2} \cdot \mathrm{yr}\right)$ & 46.0 & 42.8 & $7 \%$ & 38.0 & $17 \%$ & 27.9 & 33.5 & $17 \%$ & 31.2 & $11 \%$ \\
\hline Gas $\left(k B t u / \mathrm{ft}^{2} \cdot \mathrm{yr}\right)$ & 24.4 & 24.9 & $-2 \%$ & 25.6 & $-5 \%$ & 12.1 & 12.0 & $-1 \%$ & 12.0 & $-1 \%$ \\
\hline Net source $\left(\mathrm{kBtu} / \mathrm{ft}^{2} \cdot \mathrm{yr}\right)$ & 156.7 & 148.3 & $5 \%$ & 151.9 & $3 \%$ & 16.0 & 31.7 & $50 \%$ & 25.3 & $37 \%$ \\
\hline Peak electrical demand $\left(\mathrm{W} / \mathrm{ft}^{2}\right)$ & 5.1 & 4.9 & $4 \%$ & 4.5 & $12 \%$ & 2.5 & 3.0 & $17 \%$ & 2.8 & $11 \%$ \\
\hline Energy water (gal/ft².yr) & 17.7 & 16.4 & $7 \%$ & 14.5 & $18 \%$ & 7.0 & 8.9 & $21 \%$ & 8.1 & $14 \%$ \\
\hline Energy cost $\left(\$ / \mathrm{ft}^{2} \cdot \mathrm{yr}\right)$ & 1.52 & 1.44 & $5 \%$ & 1.32 & $13 \%$ & 0.88 & 1.03 & $15 \%$ & 0.97 & $9 \%$ \\
\hline Energy equivalent carbon $\left(\mathrm{Ib} / \mathrm{ft}^{2} \cdot \mathrm{yr}\right)$ & 10.2 & 9.6 & $6 \%$ & 7.8 & $24 \%$ & 4.2 & 5.1 & $18 \%$ & 4.7 & $11 \%$ \\
\hline
\end{tabular}


Table 4-17 Sector-Wide Average Use Intensity Metrics for Lighting Scenarios: SI units

\begin{tabular}{|c|c|c|c|c|c|c|c|c|c|c|}
\hline Use Intensity Metric & Base & $\begin{array}{c}\text { Base } \\
20 \% \\
\text { LPD }\end{array}$ & $\begin{array}{c}\text { Base } \\
20 \% \\
\text { LPD } \\
\text { Savings }\end{array}$ & $\begin{array}{c}\text { Base } \\
50 \% \\
\text { LPD }\end{array}$ & $\begin{array}{c}\text { Base } \\
50 \% \\
\text { LPD } \\
\text { Savings }\end{array}$ & $\begin{array}{l}\text { Max } \\
\text { Tech }\end{array}$ & $\begin{array}{l}\text { Max } \\
\text { Tech } \\
\text { Base } \\
\text { LPD }\end{array}$ & $\begin{array}{c}\text { Max } \\
\text { Tech } \\
\text { Base } \\
\text { LPD } \\
\text { Savings }\end{array}$ & $\begin{array}{l}\text { Max } \\
\text { Tech } \\
20 \% \\
\text { LPD }\end{array}$ & $\begin{array}{c}\text { Max } \\
\text { Tech } \\
20 \% \\
\text { LPD } \\
\text { Savings }\end{array}$ \\
\hline Total site $\left(\mathrm{MJ} / \mathrm{m}^{2} \cdot \mathrm{yr}\right)$ & 803 & 773 & $4 \%$ & 726 & $10 \%$ & 458 & 519 & $12 \%$ & 494 & $7 \%$ \\
\hline PV production $\left(\mathrm{MJ} / \mathrm{m}^{2} \cdot \mathrm{yr}\right)$ & 0 & 0 & $0 \%$ & 0 & $0 \%$ & 319 & 319 & $0 \%$ & 319 & $0 \%$ \\
\hline Net site $\left(\mathrm{MJ} / \mathrm{m}^{2} \cdot \mathrm{yr}\right)$ & 803 & 773 & $4 \%$ & 726 & $10 \%$ & 139 & 200 & $31 \%$ & 175 & $21 \%$ \\
\hline Lights $\left(\mathrm{MJ} / \mathrm{m}^{2} \cdot \mathrm{yr}\right)$ & 143 & 115 & $20 \%$ & 73 & $49 \%$ & 51 & 101 & $49 \%$ & 81 & $37 \%$ \\
\hline Cooling equipment $\left(\mathrm{MJ} / \mathrm{m}^{2} \cdot \mathrm{yr}\right)$ & 103 & 98 & $5 \%$ & 90 & $13 \%$ & 59 & 67 & $12 \%$ & 64 & $7 \%$ \\
\hline Heating equipment $\left(\mathrm{MJ} / \mathrm{m}^{2} \cdot \mathrm{yr}\right)$ & 199 & 205 & $-3 \%$ & 211 & $-6 \%$ & 59 & 58 & $-2 \%$ & 58 & $-2 \%$ \\
\hline Fans $\left(\mathrm{MJ} / \mathrm{m}^{2} \cdot \mathrm{yr}\right)$ & 52 & 50 & $4 \%$ & 48 & $9 \%$ & 19 & 22 & $11 \%$ & 20 & $6 \%$ \\
\hline Pumps (MJ/m².yr) & 6 & 6 & $4 \%$ & 5 & $11 \%$ & 4 & 5 & $10 \%$ & 5 & $5 \%$ \\
\hline Plug and process electricity $\left(\mathrm{MJ} / \mathrm{m}^{2} \cdot \mathrm{yr}\right)$ & 115 & 115 & $0 \%$ & 115 & $0 \%$ & 115 & 115 & $0 \%$ & 115 & $0 \%$ \\
\hline Process gas $\left(\mathrm{MJ} / \mathrm{m}^{2} \cdot \mathrm{yr}\right)$ & 60 & 60 & $0 \%$ & 60 & $0 \%$ & 60 & 60 & $0 \%$ & 60 & $0 \%$ \\
\hline Refrigeration $\left(\mathrm{MJ} / \mathrm{m}^{2} \cdot \mathrm{yr}\right)$ & 50 & 50 & $0 \%$ & 50 & $0 \%$ & 35 & 35 & $0 \%$ & 35 & $0 \%$ \\
\hline Service water heating $\left(\mathrm{MJ} / \mathrm{m}^{2} \cdot \mathrm{yr}\right)$ & 28 & 28 & $0 \%$ & 28 & $0 \%$ & 26 & 26 & $0 \%$ & 26 & $0 \%$ \\
\hline Total site electricity $\left(\mathrm{MJ} / \mathrm{m}^{2} \cdot \mathrm{yr}\right)$ & 523 & 486 & $7 \%$ & 432 & $17 \%$ & 317 & 381 & $17 \%$ & 355 & $11 \%$ \\
\hline Gas $\left(\mathrm{MJ} / \mathrm{m}^{2} \cdot \mathrm{yr}\right)$ & 277 & 283 & $-2 \%$ & 291 & $-5 \%$ & 138 & 136 & $-1 \%$ & 136 & $-1 \%$ \\
\hline Net source $\left(\mathrm{MJ} / \mathrm{m}^{2} \cdot \mathrm{yr}\right)$ & 1,781 & 1,685 & $5 \%$ & 1726 & $3 \%$ & 182 & 360 & $50 \%$ & 288 & $37 \%$ \\
\hline Peak electrical demand $\left(\mathrm{W} / \mathrm{m}^{2}\right)$ & 55 & 53 & $4 \%$ & 48 & $12 \%$ & 27 & 32 & $17 \%$ & 30 & $11 \%$ \\
\hline Energy water $\left(\mathrm{l} / \mathrm{m}^{2} \cdot \mathrm{yr}\right)$ & 721 & 668 & $7 \%$ & 591 & $18 \%$ & 285 & 363 & $21 \%$ & 330 & $14 \%$ \\
\hline Energy cost $\left(\$ / \mathrm{m}^{2} \cdot \mathrm{yr}\right)$ & 16.36 & 15.50 & $5 \%$ & 14.21 & $13 \%$ & 9.47 & 11.09 & $15 \%$ & 10.44 & $9 \%$ \\
\hline Energy equivalent carbon $\left(\mathrm{kg} / \mathrm{m}^{2} \cdot \mathrm{yr}\right)$ & 49.8 & 46.9 & $6 \%$ & 38.1 & $24 \%$ & 20.5 & 24.9 & $18 \%$ & 22.9 & $11 \%$ \\
\hline
\end{tabular}




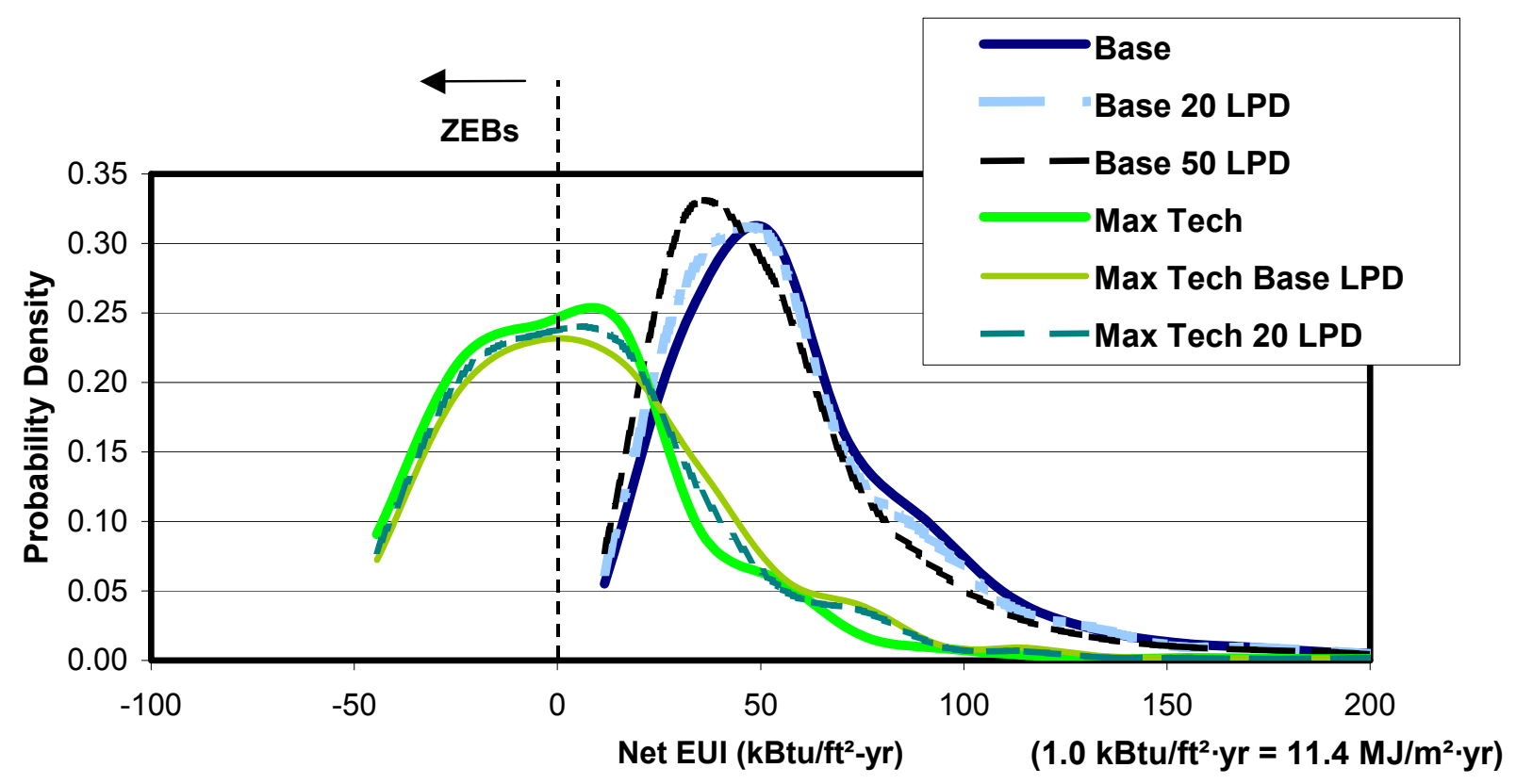

Figure 4-17 PDFs for lighting scenarios

\subsubsection{Daylighting}

The modeling results show that daylight harvesting is somewhat significant for current minimumstandard practice, but results in relatively little improvement in energy performance in future ZEBs. Table 4-18 and Table 4-19 list the results for the entire commercial sector for the various daylighting scenarios and compares them to the Base and Max Tech scenarios.

The results show that if daylighting controls were included in all new buildings, whole-building EUIs across the entire sector could be lowered by $2.6 \mathrm{kBtu} / \mathrm{ft}^{2} \cdot \mathrm{yr}\left(30 \mathrm{MJ} / \mathrm{m}^{2} \cdot \mathrm{yr}\right)$ or $4 \%$ relative to current minimum-standard construction. If rooftop fenestration is also added to better illuminate interiors, wholebuilding EUIs can be lowered by $3.7 \mathrm{kBtu} / \mathrm{ft}^{2} \cdot \mathrm{yr}\left(42 \mathrm{MJ} / \mathrm{m}^{2} \cdot \mathrm{yr}\right)$ or $5 \%$. The lighting technologies are fixed at 90.1-2004 code levels.

In the ZEB context, daylighting controls lower EUIs by only $1.3 \mathrm{kBtu} / \mathrm{ft}^{2} \cdot \mathrm{yr}\left(15 \mathrm{MJ} / \mathrm{m}^{2} \cdot \mathrm{yr}\right)$ because the lighting equipment being turned down is more efficient.

Figure 4-18 shows the PDF curves for the various scenarios related to daylighting. Although daylighting produces a noticeable shift in the Base distribution, changes to the Max Tech distribution are minimal. 
Table 4-18 Sector-Wide Average Use Intensity Metrics for Daylighting Scenarios: IP units

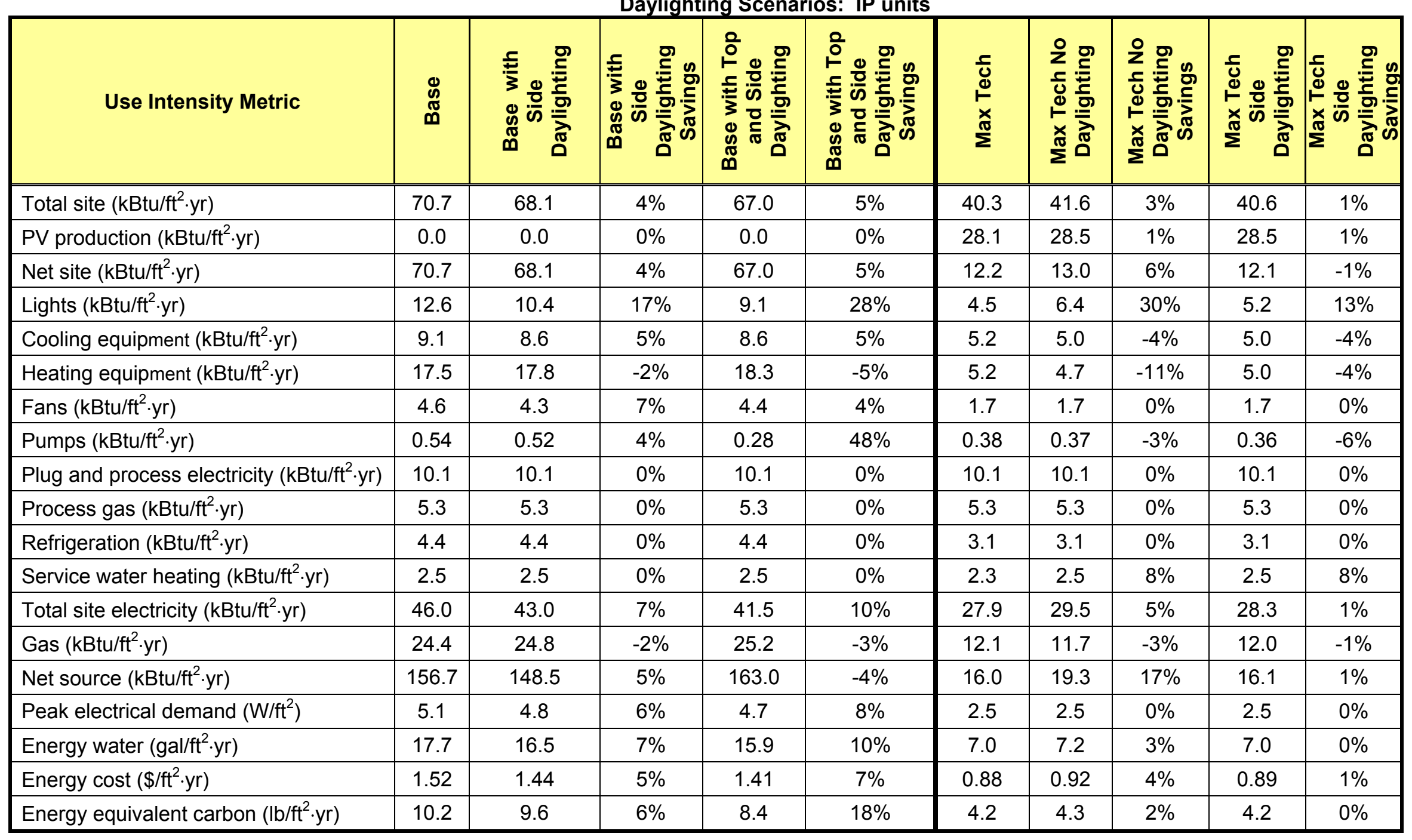


Table 4-19 Sector-Wide Average Use Intensity Metrics for Daylighting Scenarios: SI units

\begin{tabular}{|c|c|c|c|c|c|c|c|c|c|c|}
\hline Use Intensity Metric & $\begin{array}{l}\text { Ð } \\
\text { Ф } \\
\text { Ф }\end{array}$ & 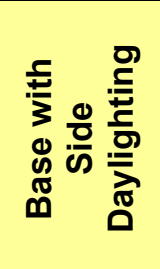 & 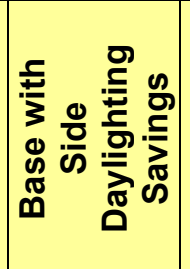 & 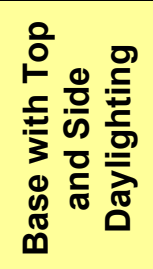 & 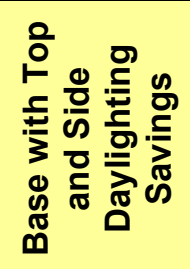 & $\begin{array}{l}\frac{1}{0} \\
\stackrel{d}{-} \\
x \\
\stackrel{\pi}{\Sigma}\end{array}$ & 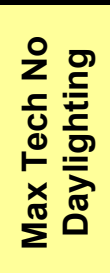 & 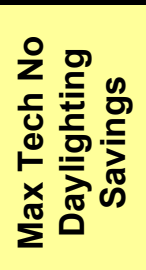 & 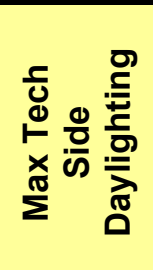 & 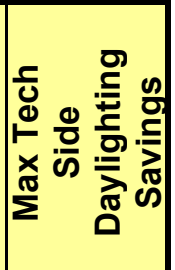 \\
\hline Total site $\left(\mathrm{MJ} / \mathrm{m}^{2} \cdot \mathrm{yr}\right)$ & 803 & 774 & $4 \%$ & 761 & $5 \%$ & 458 & 473 & $3 \%$ & 461 & $1 \%$ \\
\hline PV production $\left(\mathrm{MJ} / \mathrm{m}^{2} \cdot \mathrm{yr}\right)$ & 0 & 0 & $0 \%$ & 0 & $0 \%$ & 319 & 324 & $1 \%$ & 324 & $1 \%$ \\
\hline Lights $\left(\mathrm{MJ} / \mathrm{m}^{2} \cdot \mathrm{yr}\right)$ & 143 & 118 & $17 \%$ & 103 & $28 \%$ & 51 & 73 & $30 \%$ & 59 & $13 \%$ \\
\hline Cooling equipment $\left(\mathrm{MJ} / \mathrm{m}^{2} \cdot \mathrm{yr}\right)$ & 103 & 98 & $5 \%$ & 98 & $5 \%$ & 59 & 57 & $-4 \%$ & 57 & $-4 \%$ \\
\hline Heating equipment $\left(\mathrm{MJ} / \mathrm{m}^{2} \cdot \mathrm{yr}\right)$ & 199 & 202 & $-2 \%$ & 208 & $-5 \%$ & 59 & 53 & $-11 \%$ & 57 & $-4 \%$ \\
\hline Fans $\left(\mathrm{MJ} / \mathrm{m}^{2} \cdot \mathrm{yr}\right)$ & 52 & 49 & $7 \%$ & 50 & $4 \%$ & 19 & 19 & $0 \%$ & 19 & $0 \%$ \\
\hline Pumps $\left(\mathrm{MJ} / \mathrm{m}^{2} \cdot \mathrm{yr}\right)$ & 6 & 6 & $4 \%$ & 3 & $48 \%$ & 4 & 4 & $-3 \%$ & 4 & $-6 \%$ \\
\hline Total site electricity $\left(\mathrm{MJ} / \mathrm{m}^{2} \cdot \mathrm{yr}\right)$ & 523 & 489 & $7 \%$ & 472 & $10 \%$ & 317 & 335 & $5 \%$ & 322 & $1 \%$ \\
\hline Gas $\left(\mathrm{MJ} / \mathrm{m}^{2} \cdot \mathrm{yr}\right)$ & 277 & 282 & $-2 \%$ & 286 & $-3 \%$ & 138 & 133 & $-3 \%$ & 136 & $-1 \%$ \\
\hline Net source $\left(\mathrm{MJ} / \mathrm{m}^{2} \cdot \mathrm{yr}\right)$ & 1,781 & 1,688 & $5 \%$ & 1852 & $-4 \%$ & 182 & 219 & $17 \%$ & 183 & $1 \%$ \\
\hline Peak electrical demand $\left(\mathrm{W} / \mathrm{m}^{2}\right)$ & 55 & 52 & $6 \%$ & 51 & $8 \%$ & 27 & 27 & $0 \%$ & 27 & $0 \%$ \\
\hline Energy water $\left(1 / \mathrm{m}^{2} \cdot \mathrm{yr}\right)$ & 721 & 672 & $7 \%$ & 648 & $10 \%$ & 285 & 293 & $3 \%$ & 285 & $0 \%$ \\
\hline Energy cost $\left(\$ / \mathrm{m}^{2} \cdot \mathrm{yr}\right)$ & 16.36 & 15.50 & $5 \%$ & 15.18 & $7 \%$ & 9.47 & 9.90 & $4 \%$ & 9.58 & $1 \%$ \\
\hline Energy equivalent carbon $\left(\mathrm{kg} / \mathrm{m}^{2} \cdot \mathrm{yr}\right)$ & 49.8 & 46.9 & $6 \%$ & 41.0 & $18 \%$ & 20.5 & 21.0 & $2 \%$ & 20.5 & $0 \%$ \\
\hline
\end{tabular}




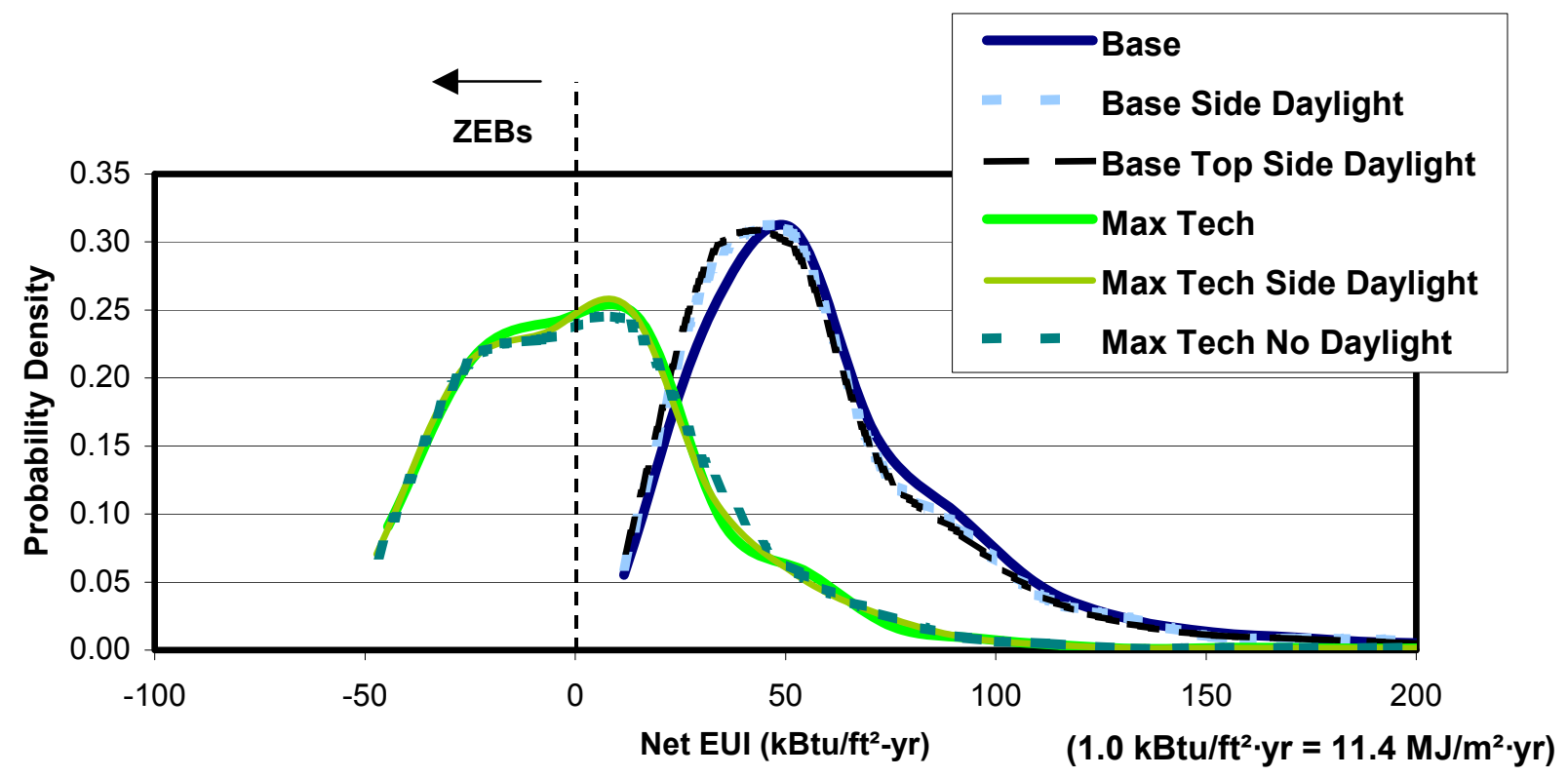

Figure 4-18 PDFs for daylighting scenarios

\subsubsection{Dynamic Windows}

The modeling results show that dynamic windows can have a significant impact on performance. Table 4-20 and Table 4-21 list results for the entire commercial sector for the dynamic window scenarios.

The results show that if dynamic windows, with the performance levels targeted by BT research goals, were included in all new buildings, EUIs across entire sector could be lowered by $5.3 \mathrm{kBtu} / \mathrm{ft}^{2} \cdot \mathrm{yr}(60$ $\mathrm{MJ} / \mathrm{m}^{2} \cdot \mathrm{yr}$ ) or $7.5 \%$. High-performance dynamic glazings save both heating and cooling energy.

In the ZEB context, high-performance dynamic windows lower EUIs by $3.5 \mathrm{kBtu} / \mathrm{ft}^{2} \cdot \mathrm{yr}\left(40 \mathrm{MJ} / \mathrm{m}^{2} \cdot \mathrm{yr}\right)$ or $22 \%$.

Figure 4-19 shows the PDF curves for the scenarios related to dynamic windows. The distributions are shifted significantly by the perturbations involving high-performance dynamic windows. 
Table 4-20 Sector-Wide Average Use Intensity Metrics for Dynamic Window Scenarios: IP units

\begin{tabular}{|c|c|c|c|c|c|c|}
\hline Use Intensity Metric & Base & $\begin{array}{c}\text { Base } \\
\text { Dynamic } \\
\text { Window }\end{array}$ & $\begin{array}{c}\text { Savings } \\
\text { from } \\
\text { Base }\end{array}$ & $\begin{array}{l}\text { Max } \\
\text { Tech }\end{array}$ & $\begin{array}{c}\text { Max } \\
\text { Tech } \\
\text { Base } \\
\text { Window }\end{array}$ & $\begin{array}{c}\text { Savings } \\
\text { toward } \\
\text { Max } \\
\text { Tech }\end{array}$ \\
\hline Total site $\left(\mathrm{kBtu} / \mathrm{ft}^{2} \cdot \mathrm{yr}\right)$ & 70.7 & 65.4 & $7.5 \%$ & 40.3 & 43.8 & $8.0 \%$ \\
\hline $\mathrm{PV}$ production $\left(\mathrm{kBtu} / \mathrm{ft}^{2} \cdot \mathrm{yr}\right)$ & 0.0 & 0.0 & $0 \%$ & 28.1 & 28.1 & $0 \%$ \\
\hline Net site $\left(\mathrm{kBtu} / \mathrm{ft}^{2} \cdot \mathrm{yr}\right)$ & 70.7 & 65.4 & $7.5 \%$ & 12.2 & 15.7 & $22.3 \%$ \\
\hline Lights $\left(\mathrm{kBtu} / \mathrm{ft}^{2} \cdot \mathrm{yr}\right)$ & 12.6 & 12.6 & $0 \%$ & 4.5 & 4.6 & $2.2 \%$ \\
\hline Cooling equipment $\left(\mathrm{kBtu} / \mathrm{ft}^{2} \cdot \mathrm{yr}\right)$ & 9.1 & 8.2 & $9.9 \%$ & 5.2 & 5.7 & $8.8 \%$ \\
\hline Heating equipment $\left(\mathrm{kBtu} / \mathrm{ft}^{2} \cdot \mathrm{yr}\right)$ & 17.5 & 14.7 & $16.0 \%$ & 5.2 & 7.2 & $27.8 \%$ \\
\hline Fans $\left(\mathrm{kBtu} / \mathrm{ft}^{2} \cdot \mathrm{yr}\right)$ & 4.6 & 3.7 & $19.6 \%$ & 1.7 & 2.1 & $19.1 \%$ \\
\hline Pumps (kBtu/ft $\left.{ }^{2} \cdot y r\right)$ & 0.54 & 0.47 & $13.0 \%$ & 0.38 & 0.44 & $13.6 \%$ \\
\hline $\begin{array}{l}\text { Plug and process electricity } \\
\left(\mathrm{kBtu} / \mathrm{ft}^{2} \cdot \mathrm{yr}\right)\end{array}$ & 10.1 & 10.1 & $0 \%$ & 10.1 & 10.1 & $0 \%$ \\
\hline Process gas $\left(\mathrm{kBtu} / \mathrm{ft}^{2} \cdot \mathrm{yr}\right)$ & 5.3 & 5.3 & $0 \%$ & 5.3 & 5.3 & $0 \%$ \\
\hline Refrigeration $\left(\mathrm{kBtu} / \mathrm{ft}^{2} \cdot \mathrm{yr}\right)$ & 4.4 & 4.4 & $0 \%$ & 3.1 & 3.1 & $0 \%$ \\
\hline Service water heating $\left(\mathrm{kBtu} / \mathrm{ft}^{2} \cdot \mathrm{yr}\right)$ & 2.5 & 2.5 & $0 \%$ & 2.3 & 2.3 & $0 \%$ \\
\hline Total site electricity $\left(\mathrm{kBtu} / \mathrm{ft}^{2} \cdot \mathrm{yr}\right)$ & 46.0 & 43.4 & $5.7 \%$ & 27.9 & 29.5 & $5.4 \%$ \\
\hline Gas (kBtu/ft' $\left.{ }^{2} \cdot y r\right)$ & 24.4 & 21.7 & $11.1 \%$ & 12.1 & 14.0 & $13.6 \%$ \\
\hline Net source $\left(\mathrm{kBtu} / \mathrm{ft}^{2} \cdot \mathrm{yr}\right)$ & 156.7 & 146.5 & $6.5 \%$ & 16.0 & 22.6 & $29.2 \%$ \\
\hline Peak electrical demand $\left(\mathrm{W} / \mathrm{ft}^{2}\right)$ & 5.1 & 4.6 & $9.8 \%$ & 2.5 & 2.9 & $13.8 \%$ \\
\hline Energy water (gal/ft $\left.{ }^{2} \cdot y r\right)$ & 17.7 & 16.8 & $5.0 \%$ & 7.0 & 7.4 & $4.6 \%$ \\
\hline Energy cost $\left(\$ / \mathrm{ft}^{2} \cdot \mathrm{yr}\right)$ & 1.52 & 1.41 & $7.2 \%$ & 0.88 & 0.95 & $7.4 \%$ \\
\hline Energy equivalent carbon $\left(\mathrm{lb} / \mathrm{ft}^{2} \cdot \mathrm{yr}\right)$ & 10.2 & 9.6 & $6.2 \%$ & 4.2 & 4.5 & $6.8 \%$ \\
\hline
\end{tabular}


Table 4-21 Sector-Wide Average Use Intensity Metrics for Dynamic Window Scenarios: SI units

\begin{tabular}{|c|c|c|c|c|c|c|}
\hline Use Intensity Metric & Base & $\begin{array}{c}\text { Base } \\
\text { Dynamic } \\
\text { Window }\end{array}$ & $\begin{array}{c}\text { Savings } \\
\text { from } \\
\text { Base }\end{array}$ & $\begin{array}{l}\text { Max } \\
\text { Tech }\end{array}$ & $\begin{array}{c}\text { Max } \\
\text { Tech } \\
\text { Base } \\
\text { Window }\end{array}$ & $\begin{array}{c}\text { Savings } \\
\text { toward } \\
\text { Max } \\
\text { Tech }\end{array}$ \\
\hline Total site $\left(\mathrm{MJ} / \mathrm{m}^{2} \cdot \mathrm{yr}\right)$ & 803 & 743 & $7.5 \%$ & 458 & 498 & $8.0 \%$ \\
\hline $\mathrm{PV}$ production $\left(\mathrm{MJ} / \mathrm{m}^{2} \cdot \mathrm{yr}\right)$ & 0 & 0 & $0 \%$ & 319 & 319 & $0 \%$ \\
\hline Net site $\left(\mathrm{MJ} / \mathrm{m}^{2} \cdot \mathrm{yr}\right)$ & 803 & 743 & $7.5 \%$ & 139 & 178 & $22.3 \%$ \\
\hline Lights $\left(\mathrm{MJ} / \mathrm{m}^{2} \cdot \mathrm{yr}\right)$ & 143 & 143 & $0 \%$ & 51 & 52 & $2.2 \%$ \\
\hline Cooling equipment $\left(\mathrm{MJ} / \mathrm{m}^{2} \cdot \mathrm{yr}\right)$ & 103 & 93 & $9.9 \%$ & 59 & 65 & $8.8 \%$ \\
\hline Heating equipment $\left(\mathrm{MJ} / \mathrm{m}^{2} \cdot \mathrm{yr}\right)$ & 199 & 167 & $16.0 \%$ & 59 & 82 & $27.8 \%$ \\
\hline Fans $\left(\mathrm{MJ} / \mathrm{m}^{2} \cdot \mathrm{yr}\right)$ & 52 & 42 & $19.6 \%$ & 19 & 24 & $19.1 \%$ \\
\hline Pumps $\left(\mathrm{MJ} / \mathrm{m}^{2} \cdot \mathrm{yr}\right)$ & 6 & 5 & $13.0 \%$ & 4 & 5 & $13.6 \%$ \\
\hline $\begin{array}{l}\text { Plug and process electricity } \\
\left(\mathrm{MJ} / \mathrm{m}^{2} \cdot \mathrm{yr}\right)\end{array}$ & 115 & 115 & $0 \%$ & 115 & 115 & $0 \%$ \\
\hline Process gas $\left(\mathrm{MJ} / \mathrm{m}^{2} \cdot \mathrm{yr}\right)$ & 60 & 60 & $0 \%$ & 60 & 60 & $0 \%$ \\
\hline Refrigeration $\left(\mathrm{MJ} / \mathrm{m}^{2} \cdot \mathrm{yr}\right)$ & 50 & 50 & $0 \%$ & 35 & 35 & $0 \%$ \\
\hline Service water heating $\left(\mathrm{MJ} / \mathrm{m}^{2} \cdot \mathrm{yr}\right)$ & 28 & 28 & $0 \%$ & 26 & 26 & $0 \%$ \\
\hline Total site electricity $\left(\mathrm{MJ} / \mathrm{m}^{2} \cdot \mathrm{yr}\right)$ & 523 & 493 & $5.7 \%$ & 317 & 335 & $5.4 \%$ \\
\hline Gas $\left(\mathrm{MJ} / \mathrm{m}^{2} \cdot \mathrm{yr}\right)$ & 277 & 247 & $11.1 \%$ & 138 & 159 & $13.6 \%$ \\
\hline Net source $\left(\mathrm{MJ} / \mathrm{m}^{2} \cdot \mathrm{yr}\right)$ & 1781 & 1665 & $6.5 \%$ & 182 & 257 & $29.2 \%$ \\
\hline Peak electrical demand $\left(\mathrm{W} / \mathrm{m}^{2}\right)$ & 55 & 50 & $9.8 \%$ & 27 & 31 & $13.8 \%$ \\
\hline Energy water $\left(\mathrm{l} / \mathrm{m}^{2} \cdot \mathrm{yr}\right)$ & 721 & 685 & $5.0 \%$ & 285 & 302 & $4.6 \%$ \\
\hline Energy cost $\left(\$ / \mathrm{m}^{2} \cdot \mathrm{yr}\right)$ & 16.36 & 15.18 & $7.2 \%$ & 9.47 & 10.23 & $7.4 \%$ \\
\hline Energy equivalent carbon $\left(\mathrm{kg} / \mathrm{m}^{2} \cdot \mathrm{yr}\right)$ & 49.8 & 46.9 & $6.2 \%$ & 20.5 & 22.0 & $6.8 \%$ \\
\hline
\end{tabular}




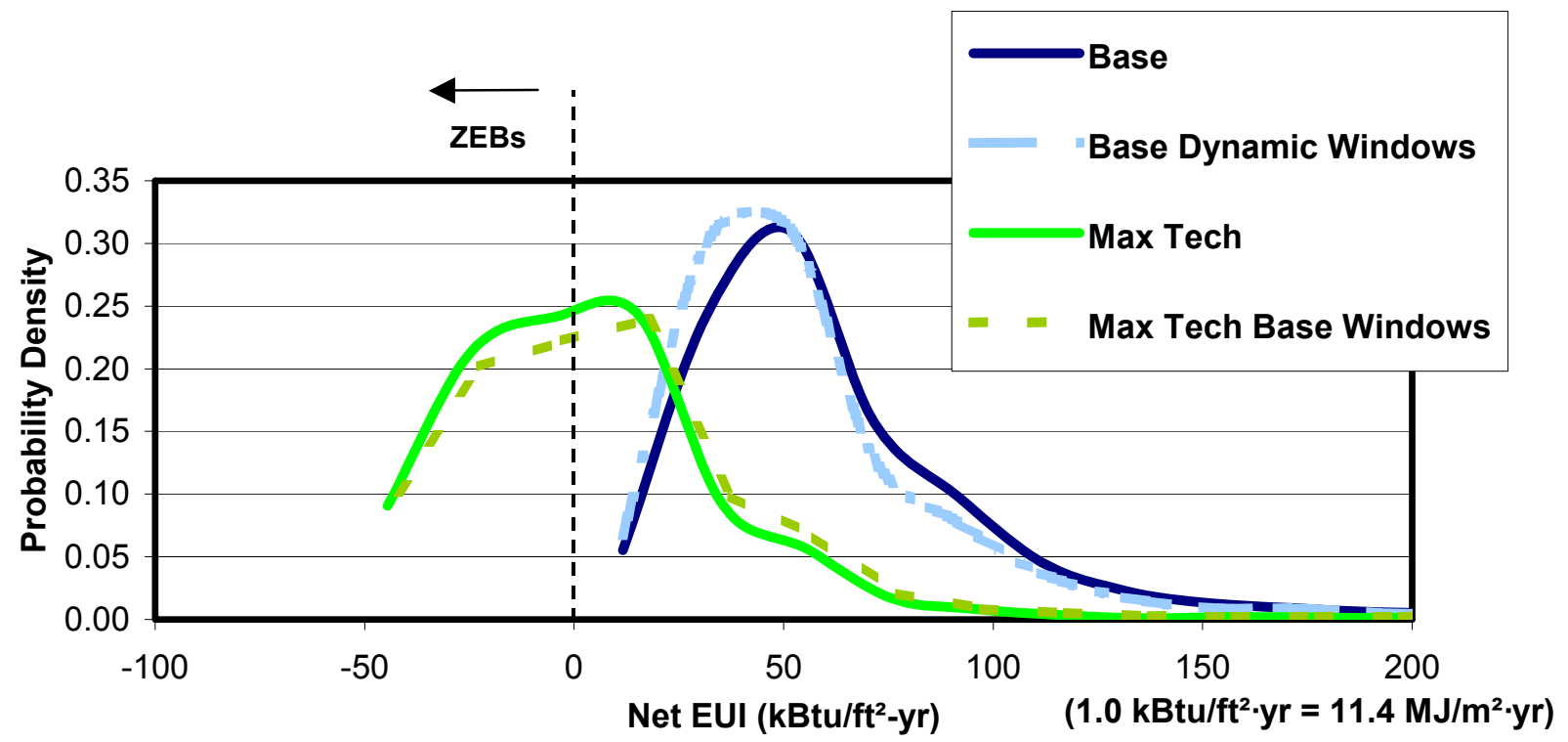

Figure 4-19 PDFs for dynamic window scenarios

\subsubsection{Insulation}

The modeling results show that opaque thermal insulation can have a significant impact on performance in the commercial sector. Table 4-22 and Table 4-23 list results for the entire commercial sector for the insulation scenarios.

The results show that if opaque insulation levels are increased to the levels specified in a draft version of Standard 189P, EUIs across the entire sector could be lowered by $4.9 \mathrm{kBtu} / \mathrm{ft}^{2} \cdot \mathrm{yr}\left(56 \mathrm{MJ} / \mathrm{m}^{2} \cdot \mathrm{yr}\right)$ or $6.9 \%$. High-performance insulation can save heating and cooling energy.

In the ZEB context, high-performance insulation lowers EUIs by $7.9 \mathrm{kBtu} / \mathrm{ft}^{2} \cdot \mathrm{yr}\left(90 \mathrm{MJ} / \mathrm{m}^{2} \cdot \mathrm{yr}\right)$ or $39 \%$.

Figure 4-20 shows the PDF curves for the scenarios related to opaque insulation. The distributions are shifted significantly by the perturbations involving insulation.

The results indicate that improving the levels of insulation is important to reaching the ZEB goal. Studying the results in Table 4-4 and Table 4-5 shows that improved insulation facilitates high performance in all climates, most notably in colder climates. 
Table 4-22 Sector-Wide Average Use Intensity Metrics for Insulation Scenarios: IP units

\begin{tabular}{|c|c|c|c|c|c|c|}
\hline Use Intensity Metric & Base & $\begin{array}{c}\text { Base } \\
\text { High } \\
\text { Envelope }\end{array}$ & $\begin{array}{c}\text { Savings } \\
\text { from } \\
\text { Base }\end{array}$ & $\begin{array}{l}\text { Max } \\
\text { Tech }\end{array}$ & $\begin{array}{c}\text { Max } \\
\text { Tech } \\
\text { Base } \\
\text { Envelope }\end{array}$ & $\begin{array}{c}\text { Savings } \\
\text { toward } \\
\text { Max } \\
\text { Tech }\end{array}$ \\
\hline Total site $\left(\mathrm{kBtu} / \mathrm{ft}^{2} \cdot \mathrm{yr}\right)$ & 70.7 & 65.8 & $6.9 \%$ & 40.3 & 48.3 & $17 \%$ \\
\hline PV production (kBtu/ft² $\cdot y r)$ & 0.0 & 0.0 & $0 \%$ & 28.1 & 28.1 & $0 \%$ \\
\hline Net site $\left(\mathrm{kBtu} / \mathrm{ft}^{2} \cdot \mathrm{yr}\right)$ & 70.7 & 65.8 & $6.9 \%$ & 12.2 & 20.1 & $39 \%$ \\
\hline Lights $\left(\mathrm{kBtu} / \mathrm{ft}^{2} \cdot \mathrm{yr}\right)$ & 12.6 & 12.6 & $0.0 \%$ & 4.5 & 4.5 & $0 \%$ \\
\hline Cooling equipment $\left(\mathrm{kBtu} / \mathrm{ft}^{2} \cdot \mathrm{yr}\right)$ & 9.1 & 8.2 & $9.9 \%$ & 5.2 & 5.8 & $10 \%$ \\
\hline Heating equipment $\left(\mathrm{kBtu} / \mathrm{ft}^{2} \cdot \mathrm{yr}\right)$ & 17.5 & 14.9 & $14.9 \%$ & 5.2 & 10.9 & $52 \%$ \\
\hline Fans $\left(\mathrm{kBtu} / \mathrm{ft}^{2} \cdot \mathrm{yr}\right)$ & 4.6 & 3.8 & $17.4 \%$ & 1.7 & 2.3 & $26 \%$ \\
\hline Pumps (kBtu/ft² $\cdot \mathrm{yr})$ & 0.54 & 0.50 & $7.4 \%$ & 0.38 & 0.45 & $16 \%$ \\
\hline $\begin{array}{l}\text { Plug and process electricity } \\
\left(\mathrm{kBtu} / \mathrm{ft}^{2} \cdot \mathrm{yr}\right)\end{array}$ & 10.1 & 10.1 & $0 \%$ & 10.1 & 10.1 & $0 \%$ \\
\hline Process gas $\left(\mathrm{kBtu} / \mathrm{ft}^{2} \cdot \mathrm{yr}\right)$ & 5.3 & 5.3 & $0 \%$ & 5.3 & 5.3 & $0 \%$ \\
\hline Refrigeration $\left(\mathrm{kBtu} / \mathrm{ft}^{2} \cdot \mathrm{yr}\right)$ & 4.4 & 4.4 & $0 \%$ & 3.1 & 3.1 & $0 \%$ \\
\hline Service water heating $\left(\mathrm{kBtu} / \mathrm{ft}^{2} \cdot \mathrm{yr}\right)$ & 2.5 & 2.5 & $0 \%$ & 2.3 & 2.3 & $0 \%$ \\
\hline Total site electricity $\left(\mathrm{kBtu} / \mathrm{ft}^{2} \cdot \mathrm{yr}\right)$ & 46.0 & 43.6 & $5.2 \%$ & 27.9 & 30.2 & $8 \%$ \\
\hline Gas $\left(k B t u / f t^{2} \cdot y r\right)$ & 24.4 & 21.9 & $10.3 \%$ & 12.1 & 17.8 & $32 \%$ \\
\hline Net source $\left(\mathrm{kBtu} / \mathrm{ft}^{2} \cdot \mathrm{yr}\right)$ & 156.7 & 147.4 & $5.9 \%$ & 16.0 & 26.4 & $39 \%$ \\
\hline Peak electrical demand $\left(\mathrm{W} / \mathrm{ft}^{2}\right)$ & 5.1 & 4.6 & $9.8 \%$ & 2.5 & 3.2 & $22 \%$ \\
\hline Energy water $\left(\mathrm{gal} / \mathrm{ft}^{2} \cdot \mathrm{yr}\right)$ & 17.7 & 16.8 & $5.0 \%$ & 7.0 & 7.5 & $6 \%$ \\
\hline Energy cost $\left(\$ / \mathrm{ft}^{2} \cdot \mathrm{yr}\right)$ & 1.52 & 1.42 & $6.6 \%$ & 0.88 & 1.02 & $14 \%$ \\
\hline Energy equivalent carbon $\left(\mathrm{lb} / \mathrm{ft}^{2} \cdot \mathrm{yr}\right)$ & 10.2 & 9.6 & $5.7 \%$ & 4.2 & 4.5 & $7 \%$ \\
\hline
\end{tabular}


Table 4-23 Sector-Wide Average Use Intensity Metrics for Insulation Scenarios: SI units

\begin{tabular}{|c|c|c|c|c|c|c|}
\hline Use Intensity Metric & Base & $\begin{array}{c}\text { Base } \\
\text { High } \\
\text { Envelope }\end{array}$ & $\begin{array}{c}\text { Savings } \\
\text { from } \\
\text { Base }\end{array}$ & $\begin{array}{l}\text { Max } \\
\text { Tech }\end{array}$ & $\begin{array}{c}\text { Max } \\
\text { Tech } \\
\text { Base } \\
\text { Envelope }\end{array}$ & $\begin{array}{c}\text { Savings } \\
\text { Toward } \\
\text { Max } \\
\text { Tech }\end{array}$ \\
\hline Total site $\left(\mathrm{MJ} / \mathrm{m}^{2} \cdot \mathrm{yr}\right)$ & 803 & 748 & $6.9 \%$ & 458 & 549 & $17 \%$ \\
\hline PV production $\left(\mathrm{MJ} / \mathrm{m}^{2} \cdot \mathrm{yr}\right)$ & 0 & 0 & $0 \%$ & 319 & 319 & $0 \%$ \\
\hline Net site $\left(\mathrm{MJ} / \mathrm{m}^{2} \cdot \mathrm{yr}\right)$ & 803 & 748 & $6.9 \%$ & 139 & 228 & $39 \%$ \\
\hline Lights $\left(\mathrm{MJ} / \mathrm{m}^{2} \cdot \mathrm{yr}\right)$ & 143 & 143 & $0.0 \%$ & 51 & 51 & $0 \%$ \\
\hline Cooling equipment $\left(\mathrm{MJ} / \mathrm{m}^{2} \cdot \mathrm{yr}\right)$ & 103 & 93 & $9.9 \%$ & 59 & 66 & $10 \%$ \\
\hline Heating equipment $\left(\mathrm{MJ} / \mathrm{m}^{2} \cdot \mathrm{yr}\right)$ & 199 & 169 & $14.9 \%$ & 59 & 124 & $52 \%$ \\
\hline Fans $\left(\mathrm{MJ} / \mathrm{m}^{2} \cdot \mathrm{yr}\right)$ & 52 & 43 & $17.4 \%$ & 19 & 26 & $26 \%$ \\
\hline Pumps $\left(\mathrm{MJ} / \mathrm{m}^{2} \cdot \mathrm{yr}\right)$ & 6 & 6 & $7.4 \%$ & 4 & 5 & $16 \%$ \\
\hline $\begin{array}{l}\text { Plug and process electricity } \\
\left(\mathrm{MJ} / \mathrm{m}^{2} \cdot \mathrm{yr}\right)\end{array}$ & 115 & 115 & $0 \%$ & 115 & 115 & $0 \%$ \\
\hline Process gas $\left(\mathrm{MJ} / \mathrm{m}^{2} \cdot \mathrm{yr}\right)$ & 60 & 60 & $0 \%$ & 60 & 60 & $0 \%$ \\
\hline Refrigeration $\left(\mathrm{MJ} / \mathrm{m}^{2} \cdot \mathrm{yr}\right)$ & 50 & 50 & $0 \%$ & 35 & 35 & $0 \%$ \\
\hline Service water heating $\left(\mathrm{MJ} / \mathrm{m}^{2} \cdot \mathrm{yr}\right)$ & 28 & 28 & $0 \%$ & 26 & 26 & $0 \%$ \\
\hline Total site electricity $\left(\mathrm{MJ} / \mathrm{m}^{2} \cdot \mathrm{yr}\right)$ & 523 & 495 & $5.2 \%$ & 317 & 343 & $8 \%$ \\
\hline Gas $\left(\mathrm{MJ} / \mathrm{m}^{2} \cdot \mathrm{yr}\right)$ & 277 & 249 & $10.3 \%$ & 138 & 202 & $32 \%$ \\
\hline Net source $\left(\mathrm{MJ} / \mathrm{m}^{2} \cdot \mathrm{yr}\right)$ & 1,781 & 1,675 & $5.9 \%$ & 182 & 300 & $39 \%$ \\
\hline Peak electrical demand $\left(\mathrm{W} / \mathrm{m}^{2}\right)$ & 55 & 50 & $9.8 \%$ & 27 & 34 & $22 \%$ \\
\hline Energy water $\left(\mathrm{l} / \mathrm{m}^{2} \cdot \mathrm{yr}\right)$ & 721 & 685 & $5.0 \%$ & 285 & 306 & $6 \%$ \\
\hline Energy cost $\left(\$ / \mathrm{m}^{2} \cdot \mathrm{yr}\right)$ & 16.36 & 15.29 & $6.6 \%$ & 9.47 & 10.98 & $14 \%$ \\
\hline Energy equivalent carbon $\left(\mathrm{kg} / \mathrm{m}^{2} \cdot \mathrm{yr}\right)$ & 49.8 & 46.9 & $5.7 \%$ & 21 & 22 & $7 \%$ \\
\hline
\end{tabular}




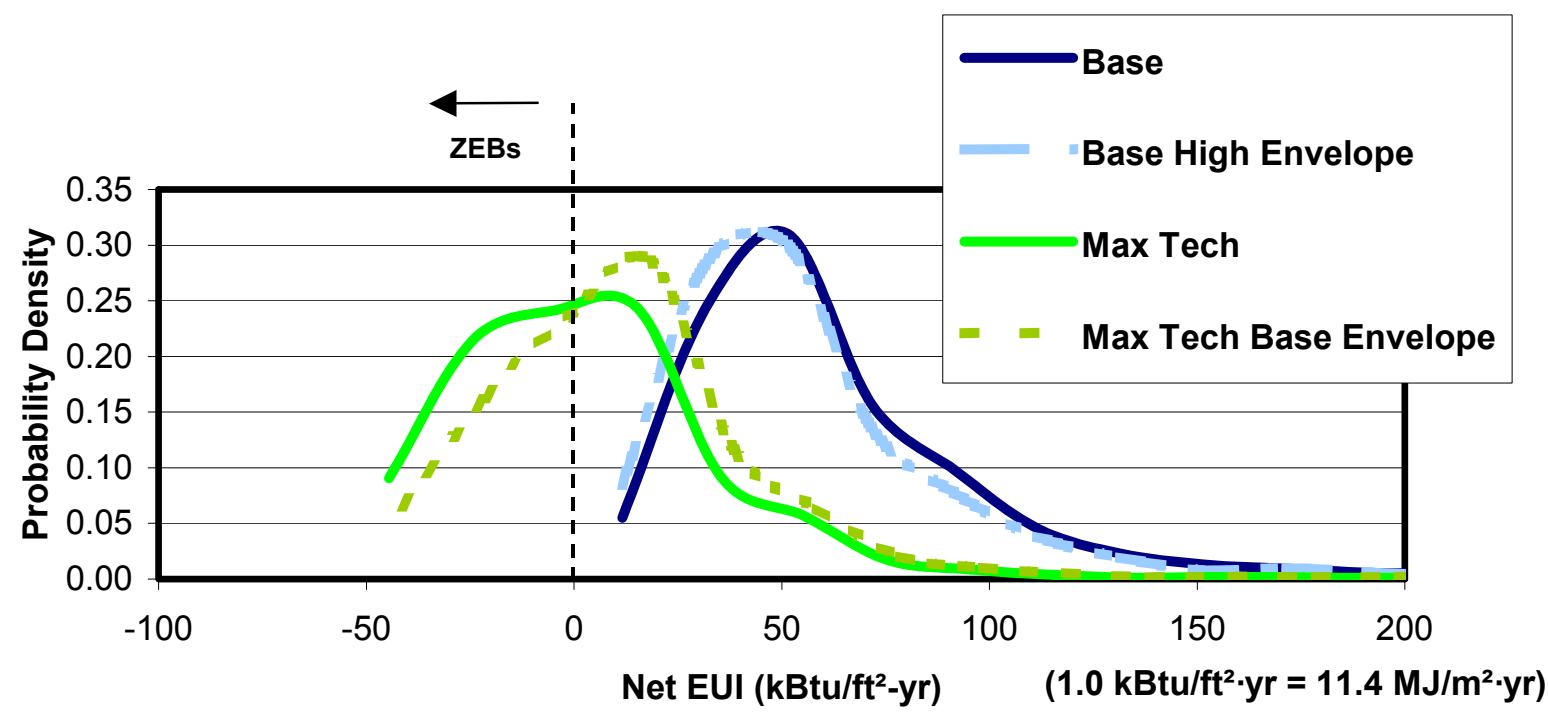

Figure 4-20 PDFs for insulation scenarios

\subsubsection{HVAC}

The modeling results show that advanced HVAC components can have a significant impact on performance. Table 4-24 and Table 4-25 list results for the entire commercial sector for the HVAC scenarios.

The results show that if HVAC component performance levels are increased to the levels assumed in this study, EUIs across the sector could be lowered by $8.2 \mathrm{kBtu} / \mathrm{ft}^{2} \cdot \mathrm{yr}\left(93 \mathrm{MJ} / \mathrm{m}^{2} \cdot \mathrm{yr}\right)$ or $11.6 \%$. The higher component efficiencies reduce cooling, heating, and fan energy but raise pump energy slightly because of the supply air temperature reset scheme based on outside air in the advanced HVAC leads to more pumping of chilled water in many locations.

In the ZEB context, advanced HVAC lowers net EUI by $5.1 \mathrm{kBtu} / \mathrm{ft}^{2} \cdot \mathrm{yr}\left(58 \mathrm{MJ} / \mathrm{m}^{2} \cdot \mathrm{yr}\right)$ or $29 \%$.

Figure 4-21 shows the PDF curves for scenarios related to HVAC. The distributions are shifted significantly by the perturbations involving HVAC component improvements.

The results indicate that improving component efficiency is important to reaching the ZEB goal. 
Table 4-24 Sector-Wide Average Use Intensity Metrics for HVAC Scenarios: IP units

\begin{tabular}{|c|c|c|c|c|c|c|}
\hline Use Intensity Metric & Base & $\begin{array}{c}\text { Base } \\
\text { High } \\
\text { HVAC }\end{array}$ & $\begin{array}{c}\text { Savings } \\
\text { from } \\
\text { Base }\end{array}$ & $\begin{array}{l}\text { Max } \\
\text { Tech }\end{array}$ & $\begin{array}{l}\text { Max } \\
\text { Tech } \\
\text { Base } \\
\text { HVAC }\end{array}$ & $\begin{array}{c}\text { Savings } \\
\text { toward } \\
\text { Max } \\
\text { Tech }\end{array}$ \\
\hline Total site $\left(\mathrm{kBtu} / \mathrm{ft}^{2} \cdot \mathrm{yr}\right)$ & 70.7 & 62.5 & $11.6 \%$ & 40.3 & 45.4 & $11 \%$ \\
\hline $\mathrm{PV}$ production $\left(\mathrm{kBtu} / \mathrm{ft}^{2} \cdot \mathrm{yr}\right)$ & 0.0 & 0.0 & $0 \%$ & 28.1 & 28.1 & $0 \%$ \\
\hline Net site $\left(\mathrm{kBtu} / \mathrm{ft}^{2} \cdot \mathrm{yr}\right)$ & 70.7 & 62.5 & $11.6 \%$ & 12.2 & 17.3 & $29 \%$ \\
\hline Lights $\left(\mathrm{kBtu} / \mathrm{ft}^{2} \cdot \mathrm{yr}\right)$ & 12.6 & 12.6 & $0 \%$ & 4.5 & 4.5 & $0 \%$ \\
\hline Cooling equipment $\left(\mathrm{kBtu} / \mathrm{ft}^{2} \cdot \mathrm{yr}\right)$ & 9.1 & 7.4 & $18.7 \%$ & 5.2 & 6.1 & $15 \%$ \\
\hline Heating equipment $\left(\mathrm{kBtu} / \mathrm{ft}^{2} \cdot \mathrm{yr}\right)$ & 17.5 & 12.2 & $30.3 \%$ & 5.2 & 8.9 & $42 \%$ \\
\hline Fans $\left(\mathrm{kBtu} / \mathrm{ft}^{2} \cdot \mathrm{yr}\right)$ & 4.6 & 3.1 & $32.6 \%$ & 1.7 & 2.5 & $32 \%$ \\
\hline Pumps (kBtu/ft² $\cdot y r)$ & 0.54 & 0.58 & $-7.4 \%$ & 0.38 & 0.35 & $-9 \%$ \\
\hline $\begin{array}{l}\text { Plug and process electricity } \\
\left(\mathrm{kBtu} / \mathrm{ft}^{2} \cdot \mathrm{yr}\right)\end{array}$ & 10.1 & 10.1 & $0 \%$ & 10.1 & 10.1 & $0 \%$ \\
\hline Process gas $\left(\mathrm{kBtu} / \mathrm{ft}^{2} \cdot \mathrm{yr}\right)$ & 5.3 & 5.3 & $0 \%$ & 5.3 & 5.3 & $0 \%$ \\
\hline Refrigeration $\left(\mathrm{kBtu} / \mathrm{ft}^{2} \cdot \mathrm{yr}\right)$ & 4.4 & 4.4 & $0 \%$ & 3.1 & 3.1 & $0 \%$ \\
\hline Service water heating $\left(\mathrm{kBtu} / \mathrm{ft}^{2} \cdot \mathrm{yr}\right)$ & 2.5 & 2.5 & $0 \%$ & 2.3 & 2.3 & $0 \%$ \\
\hline Total site electricity $\left(\mathrm{kBtu} / \mathrm{ft}^{2} \cdot \mathrm{yr}\right)$ & 46.0 & 43.0 & $6.5 \%$ & 27.9 & 29.3 & $5 \%$ \\
\hline Gas $\left(k B t u / \mathrm{ft}^{2} \cdot \mathrm{yr}\right)$ & 24.4 & 19.2 & $21.3 \%$ & 12.1 & 15.8 & $23 \%$ \\
\hline Net source $\left(\mathrm{kBtu} / \mathrm{ft}^{2} \cdot \mathrm{yr}\right)$ & 156.7 & 142.6 & $9 \%$ & 16.0 & 24.0 & $33 \%$ \\
\hline Peak electrical demand $\left(\mathrm{W} / \mathrm{ft}^{2}\right)$ & 5.1 & 4.4 & $13.7 \%$ & 2.5 & 3.0 & $17 \%$ \\
\hline Energy water $\left(\mathrm{gal} / \mathrm{ft}^{2} \cdot \mathrm{yr}\right)$ & 17.7 & 16.6 & $5.8 \%$ & 7.0 & 7.3 & $3 \%$ \\
\hline Energy cost $\left(\$ / \mathrm{ft}^{2} \cdot \mathrm{yr}\right)$ & 1.52 & 1.37 & $9.9 \%$ & 0.88 & 0.97 & $9 \%$ \\
\hline Energy equivalent carbon $\left(\mathrm{lb} / \mathrm{ft}^{2} \cdot \mathrm{yr}\right)$ & 10.2 & 9.43 & $8.0 \%$ & 4.2 & 4.6 & $8 \%$ \\
\hline
\end{tabular}


Table 4-25 Sector-Wide Average Use Intensity Metrics for HVAC Scenarios: SI units

\begin{tabular}{|c|c|c|c|c|c|c|}
\hline Use Intensity Metric & Base & $\begin{array}{c}\text { Base } \\
\text { High } \\
\text { HVAC }\end{array}$ & $\begin{array}{c}\text { Savings } \\
\text { from } \\
\text { Base }\end{array}$ & $\begin{array}{l}\text { Max } \\
\text { Tech }\end{array}$ & $\begin{array}{l}\text { Max } \\
\text { Tech } \\
\text { Base } \\
\text { HVAC }\end{array}$ & $\begin{array}{c}\text { Savings } \\
\text { toward } \\
\text { Max } \\
\text { Tech }\end{array}$ \\
\hline Total site $\left(\mathrm{MJ} / \mathrm{m}^{2} \cdot \mathrm{yr}\right)$ & 803 & 710 & $11.6 \%$ & 458 & 516 & $11 \%$ \\
\hline $\mathrm{PV}$ production $\left(\mathrm{MJ} / \mathrm{m}^{2} \cdot \mathrm{yr}\right)$ & 0 & 0 & $0 \%$ & 319 & 319 & $0 \%$ \\
\hline Net site $\left(\mathrm{MJ} / \mathrm{m}^{2} \cdot \mathrm{yr}\right)$ & 803 & 710 & $11.6 \%$ & 139 & 197 & $29 \%$ \\
\hline Lights $\left(\mathrm{MJ} / \mathrm{m}^{2} \cdot \mathrm{yr}\right)$ & 143 & 143 & $0 \%$ & 51 & 51 & $0 \%$ \\
\hline Cooling equipment $\left(\mathrm{MJ} / \mathrm{m}^{2} \cdot \mathrm{yr}\right)$ & 103 & 84 & $18.7 \%$ & 59 & 69 & $15 \%$ \\
\hline Heating equipment $\left(\mathrm{MJ} / \mathrm{m}^{2} \cdot \mathrm{yr}\right)$ & 199 & 139 & $30.3 \%$ & 59 & 101 & $42 \%$ \\
\hline Fans $\left(\mathrm{MJ} / \mathrm{m}^{2} \cdot \mathrm{yr}\right)$ & 52 & 35 & $32.6 \%$ & 19 & 28 & $32 \%$ \\
\hline Pumps $\left(\mathrm{MJ} / \mathrm{m}^{2} \cdot \mathrm{yr}\right)$ & 6 & 7 & $-7.4 \%$ & 4 & 4 & $-9 \%$ \\
\hline $\begin{array}{l}\text { Plug and process electricity } \\
\left(\mathrm{MJ} / \mathrm{m}^{2} \cdot \mathrm{yr}\right)\end{array}$ & 115 & 115 & $0 \%$ & 115 & 115 & $0 \%$ \\
\hline Process gas $\left(\mathrm{MJ} / \mathrm{m}^{2} \cdot \mathrm{yr}\right)$ & 60 & 60 & $0 \%$ & 60 & 60 & $0 \%$ \\
\hline Refrigeration $\left(\mathrm{MJ} / \mathrm{m}^{2} \cdot \mathrm{yr}\right)$ & 50 & 50 & $0 \%$ & 35 & 35 & $0 \%$ \\
\hline Service water heating $\left(\mathrm{MJ} / \mathrm{m}^{2} \cdot \mathrm{yr}\right)$ & 28 & 28 & $0 \%$ & 26 & 26 & $0 \%$ \\
\hline Total site electricity $\left(\mathrm{MJ} / \mathrm{m}^{2} \cdot \mathrm{yr}\right)$ & 523 & 489 & $6.5 \%$ & 317 & 333 & $5 \%$ \\
\hline Gas $\left(\mathrm{MJ} / \mathrm{m}^{2} \cdot \mathrm{yr}\right)$ & 277 & 218 & $21.3 \%$ & 138 & 180 & $23 \%$ \\
\hline Net source $\left(\mathrm{MJ} / \mathrm{m}^{2} \cdot \mathrm{yr}\right)$ & 1,781 & 1,620 & $9 \%$ & 182 & 273 & $33 \%$ \\
\hline Peak electrical demand $\left(\mathrm{W} / \mathrm{m}^{2}\right)$ & 55 & 47 & $13.7 \%$ & 27 & 32 & $17 \%$ \\
\hline Energy water $\left(\mathrm{l} / \mathrm{m}^{2} \cdot \mathrm{yr}\right)$ & 721 & 676 & $5.8 \%$ & 285 & 297 & $3 \%$ \\
\hline Energy cost $\left(\$ / \mathrm{m}^{2} \cdot \mathrm{yr}\right)$ & 16.36 & 14.75 & $9.9 \%$ & 9.47 & 10.44 & $9 \%$ \\
\hline Energy equivalent carbon $\left(\mathrm{kg} / \mathrm{m}^{2} \cdot \mathrm{yr}\right)$ & 49.8 & 46.0 & $8.0 \%$ & 20.5 & 22.5 & $8 \%$ \\
\hline
\end{tabular}




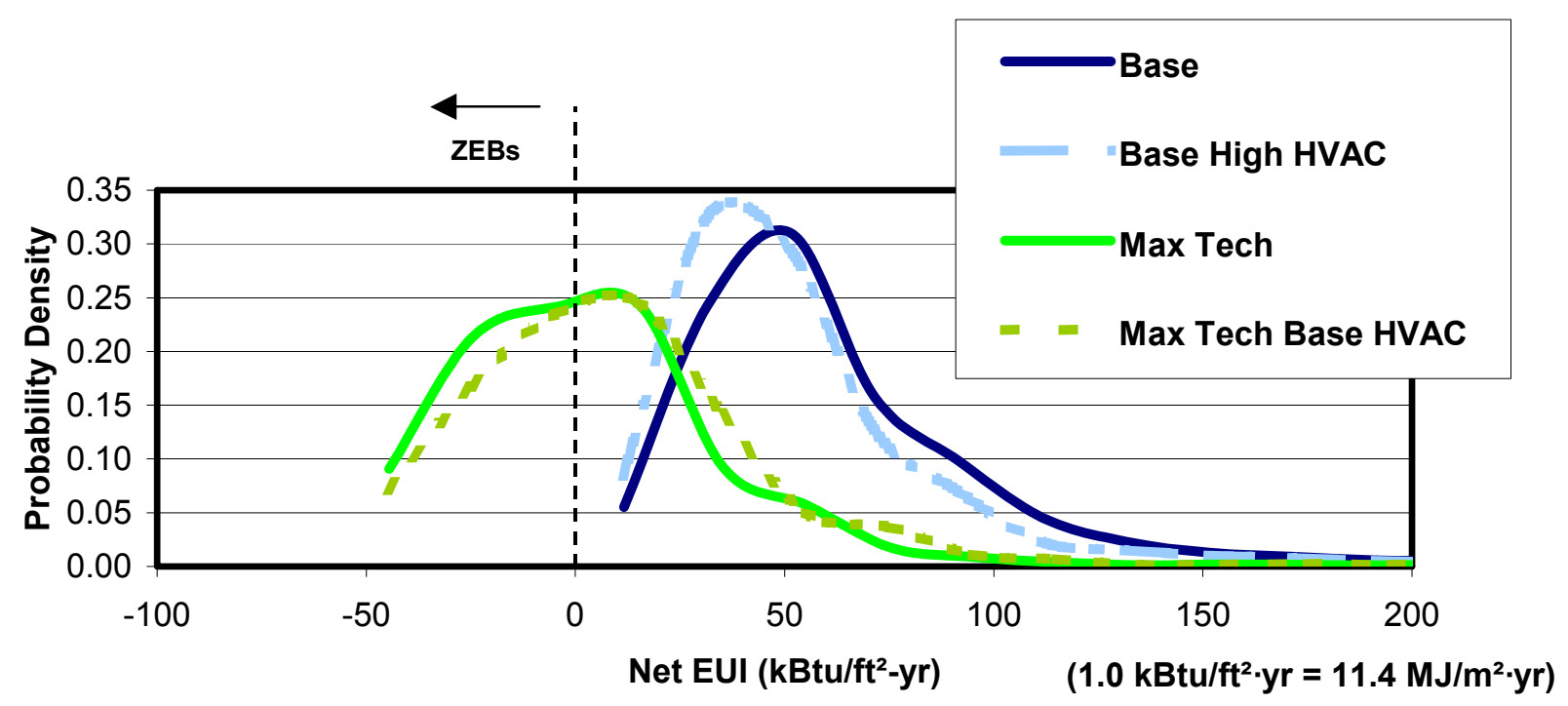

Figure 4-21 PDFs for HVAC scenarios

\subsubsection{Plug and Process Loads}

The modeling results show that reducing plug and process loads can have a pronounced effect on performance in the ZEB context. Table 4-26 and Table 4-27 list results for the entire commercial sector for the plug and process scenarios that model improved appliances.

The results show that if plug and process power densities were decreased by $25 \%$, EUIs across the entire commercial sector could be lowered by $4.4 \mathrm{kBtu} / \mathrm{ft}^{2} \cdot \mathrm{yr}\left(50 \mathrm{MJ} / \mathrm{m}^{2} \cdot \mathrm{yr}\right)$ or $7 \%$.

In the ZEB context, lowering plug and process energy use is more significant lowering net EUIs by $4.9 \mathrm{kBtu} / \mathrm{ft}^{2} \cdot \mathrm{yr}\left(56 \mathrm{MJ} / \mathrm{m}^{2} \cdot \mathrm{yr}\right)$ or $40 \%$.

Figure 4-22 shows the PDF curves for the plug and process scenarios. The distributions are not shifted in an obvious way. 
Table 4-26 Sector-Wide Average Use Intensity Metrics for

Plug and Process Scenarios: IP units

\begin{tabular}{|c|c|c|c|c|c|c|}
\hline Use Intensity Metric & Base & $\begin{array}{l}\text { Base High } \\
\text { Appliance }\end{array}$ & $\begin{array}{c}\text { Savings } \\
\text { from } \\
\text { Base }\end{array}$ & $\begin{array}{l}\text { Max } \\
\text { Tech }\end{array}$ & $\begin{array}{c}\text { Max Tech } \\
\text { High } \\
\text { Appliance }\end{array}$ & $\begin{array}{c}\text { Savings } \\
\text { toward } \\
\text { Max } \\
\text { Tech }\end{array}$ \\
\hline Total site $\left(\mathrm{kBtu} / \mathrm{ft}^{2} \cdot \mathrm{yr}\right)$ & 70.7 & 66.3 & $7 \%$ & 40.3 & 35.4 & $12 \%$ \\
\hline $\mathrm{PV}$ production $\left(\mathrm{kBtu} / \mathrm{ft}^{2} \cdot \mathrm{yr}\right)$ & 0.0 & 0.0 & N/A & 28.1 & 28.1 & $0 \%$ \\
\hline Net site $\left(\mathrm{kBtu} / \mathrm{ft}^{2} \cdot \mathrm{yr}\right)$ & 70.7 & 66.3 & $7 \%$ & 12.2 & 7.3 & $40 \%$ \\
\hline Lights $\left(\mathrm{kBtu} / \mathrm{ft}^{2} \cdot \mathrm{yr}\right)$ & 12.6 & 12.6 & $0 \%$ & 4.5 & 4.5 & $0 \%$ \\
\hline Cooling equipment $\left(\mathrm{kBtu} / \mathrm{ft}^{2} \cdot \mathrm{yr}\right)$ & 9.1 & 8.3 & $10 \%$ & 5.2 & 4.4 & $15 \%$ \\
\hline Heating equipment $\left(\mathrm{kBtu} / \mathrm{ft}^{2} \cdot \mathrm{yr}\right)$ & 17.5 & 17.9 & $-2 \%$ & 5.2 & 5.3 & $-2 \%$ \\
\hline Fans $\left(\mathrm{kBtu} / \mathrm{ft}^{2} \cdot \mathrm{yr}\right)$ & 4.6 & 4.3 & $7 \%$ & 1.7 & 1.5 & $12 \%$ \\
\hline Pumps (kBtu/ft².yr) & 0.54 & 0.50 & $8 \%$ & 0.38 & 0.34 & $11 \%$ \\
\hline $\begin{array}{l}\text { Plug and process electricity } \\
\left(\mathrm{kBtu} / \mathrm{ft}^{2} \cdot \mathrm{yr}\right)\end{array}$ & 10.1 & 7.6 & $33 \%$ & 10.1 & 7.6 & $25 \%$ \\
\hline Process gas $\left(\mathrm{kBtu} / \mathrm{ft}^{2} \cdot \mathrm{yr}\right)$ & 5.3 & 4.0 & $33 \%$ & 5.3 & 4.0 & $25 \%$ \\
\hline Refrigeration $\left(\mathrm{kBtu} / \mathrm{ft}^{2} \cdot \mathrm{yr}\right)$ & 4.4 & 4.4 & $0 \%$ & 3.1 & 3.1 & $0 \%$ \\
\hline Service water heating $\left(\mathrm{kBtu} / \mathrm{ft}^{2} \cdot \mathrm{yr}\right)$ & 2.5 & 2.5 & $0 \%$ & 2.3 & 2.3 & $0 \%$ \\
\hline Total site electricity $\left(\mathrm{kBtu} / \mathrm{ft}^{2} \cdot \mathrm{yr}\right)$ & 46.0 & 42.4 & $8 \%$ & 27.9 & 24.3 & $13 \%$ \\
\hline Gas $\left(\mathrm{kBtu} / \mathrm{ft}^{2} \cdot \mathrm{yr}\right)$ & 24.4 & 23.6 & $3 \%$ & 12.1 & 10.9 & $10 \%$ \\
\hline Net source $\left(\mathrm{kBtu} / \mathrm{ft}^{2} \cdot \mathrm{yr}\right)$ & 156.7 & 145.5 & $8 \%$ & 16.0 & -1.6 & $110 \%$ \\
\hline Peak electrical demand $\left(\mathrm{W} / \mathrm{ft}^{2}\right)$ & 5.1 & 4.9 & $4 \%$ & 2.5 & 2.3 & $8 \%$ \\
\hline Energy water $\left(\mathrm{gal} / \mathrm{ft}^{2} \cdot \mathrm{yr}\right)$ & 17.7 & 16.2 & $9 \%$ & 7.0 & 5.9 & $16 \%$ \\
\hline Energy cost $\left(\$ / \mathrm{ft}^{2} \cdot \mathrm{yr}\right)$ & 1.52 & 1.42 & $7 \%$ & 0.88 & 0.78 & $11 \%$ \\
\hline Energy equivalent carbon $\left(\mathrm{lb} / \mathrm{ft}^{2} \cdot \mathrm{yr}\right)$ & 10.2 & 9.5 & $8 \%$ & 4.2 & 3.2 & $24 \%$ \\
\hline
\end{tabular}


Table 4-27 Sector-Wide Average Use Intensity Metrics for Plug and Process Scenarios: SI units

\begin{tabular}{|c|c|c|c|c|c|c|}
\hline Use Intensity Metric & Base & $\begin{array}{l}\text { Base High } \\
\text { Appliance }\end{array}$ & $\begin{array}{c}\text { Savings } \\
\text { from } \\
\text { Base }\end{array}$ & $\begin{array}{l}\text { Max } \\
\text { Tech }\end{array}$ & $\begin{array}{c}\text { Max Tech } \\
\text { High } \\
\text { Appliance }\end{array}$ & $\begin{array}{c}\text { Savings } \\
\text { toward } \\
\text { Max } \\
\text { Tech }\end{array}$ \\
\hline Total site $\left(\mathrm{MJ} / \mathrm{m}^{2} \cdot \mathrm{yr}\right)$ & 803 & 753 & $7 \%$ & 458 & 402 & $12 \%$ \\
\hline PV production $\left(\mathrm{MJ} / \mathrm{m}^{2} \cdot \mathrm{yr}\right)$ & 0 & 0 & $\mathrm{~N} / \mathrm{A}$ & 319 & 319 & $0 \%$ \\
\hline Net site $\left(\mathrm{MJ} / \mathrm{m}^{2} \cdot \mathrm{yr}\right)$ & 803 & 753 & $7 \%$ & 139 & 83 & $40 \%$ \\
\hline Lights $\left(\mathrm{MJ} / \mathrm{m}^{2} \cdot \mathrm{yr}\right)$ & 143 & 143 & $0 \%$ & 51 & 51 & $0 \%$ \\
\hline Cooling equipment $\left(\mathrm{MJ} / \mathrm{m}^{2} \cdot \mathrm{yr}\right)$ & 103 & 94 & $10 \%$ & 59 & 50 & $15 \%$ \\
\hline Heating equipment $\left(\mathrm{MJ} / \mathrm{m}^{2} \cdot \mathrm{yr}\right)$ & 199 & 203 & $-2 \%$ & 59 & 60 & $-2 \%$ \\
\hline Fans $\left(\mathrm{MJ} / \mathrm{m}^{2} \cdot \mathrm{yr}\right)$ & 52 & 49 & $7 \%$ & 19 & 17 & $12 \%$ \\
\hline Pumps $\left(\mathrm{MJ} / \mathrm{m}^{2} \cdot \mathrm{yr}\right)$ & 6 & 6 & $8 \%$ & 4 & 4 & $11 \%$ \\
\hline $\begin{array}{l}\text { Plug and process electricity } \\
\left(\mathrm{MJ} / \mathrm{m}^{2} \cdot \mathrm{yr}\right)\end{array}$ & 115 & 86 & $33 \%$ & 115 & 86 & $25 \%$ \\
\hline Process gas $\left(\mathrm{MJ} / \mathrm{m}^{2} \cdot \mathrm{yr}\right)$ & 60 & 45 & $33 \%$ & 60 & 45 & $25 \%$ \\
\hline Refrigeration $\left(\mathrm{MJ} / \mathrm{m}^{2} \cdot \mathrm{yr}\right)$ & 50 & 50 & $0 \%$ & 35 & 35 & $0 \%$ \\
\hline Service water heating $\left(\mathrm{MJ} / \mathrm{m}^{2} \cdot \mathrm{yr}\right)$ & 28 & 28 & $0 \%$ & 26 & 26 & $0 \%$ \\
\hline Total site electricity $\left(\mathrm{MJ} / \mathrm{m}^{2} \cdot \mathrm{yr}\right)$ & 523 & 482 & $8 \%$ & 317 & 276 & $13 \%$ \\
\hline Gas $\left(M J / m^{2} \cdot y r\right)$ & 277 & 268 & $3 \%$ & 138 & 124 & $10 \%$ \\
\hline Net source $\left(\mathrm{MJ} / \mathrm{m}^{2} \cdot \mathrm{yr}\right)$ & 1,781 & 1,653 & $8 \%$ & 182 & -18 & $110 \%$ \\
\hline Peak electrical demand $\left(\mathrm{W} / \mathrm{m}^{2}\right)$ & 55 & 53 & $4 \%$ & 27 & 25 & $8 \%$ \\
\hline Energy water $\left(\mathrm{l} / \mathrm{m}^{2} \cdot \mathrm{yr}\right)$ & 721 & 660 & $9 \%$ & 285 & 240 & $16 \%$ \\
\hline Energy cost $\left(\$ / \mathrm{m}^{2} \cdot \mathrm{yr}\right)$ & 16.36 & 15.29 & $7 \%$ & 9.47 & 8.40 & $11 \%$ \\
\hline Energy equivalent carbon $\left(\mathrm{kg} / \mathrm{m}^{2} \cdot \mathrm{yr}\right)$ & 49.8 & 46.4 & $8 \%$ & 20.5 & 15.6 & $24 \%$ \\
\hline
\end{tabular}




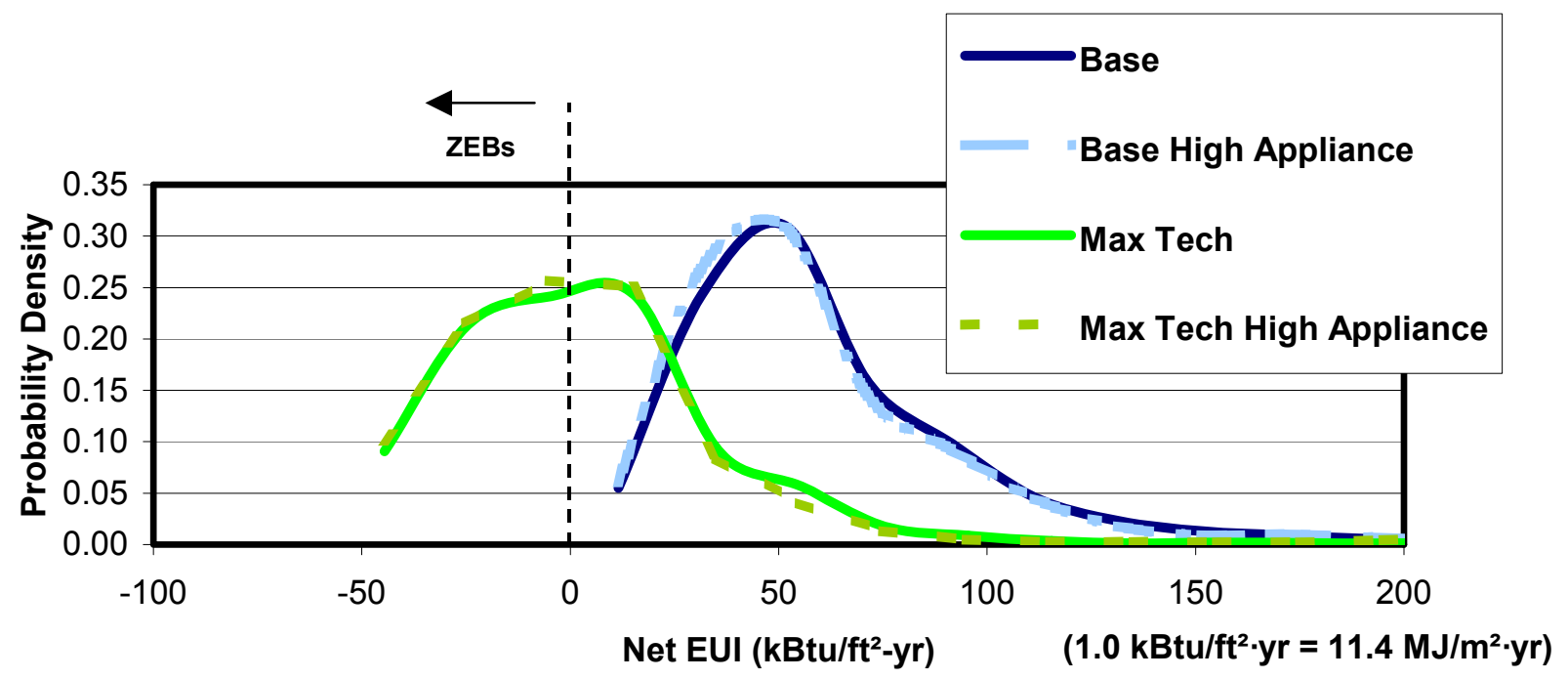

Figure 4-22 PDFs for plug and process scenarios

\subsubsection{Passive Solar Architecture}

The modeling results show relatively minor performance improvements from architectural form changes intended to model passive solar design.

Table 4-28 and Table 4-29 list the results for various intensity metrics for the scenarios related to passive solar architecture. To isolate the impact of form changes, the model results for passive solar are compared to the Base Side Daylighting scenario rather than the Base scenario because the Base Passive Solar scenario includes daylighting. Daylighting is integral to passive solar design and had to be included.

In the current practice context, the collection of passive solar form measures that were modeled saved $1 \%$ in site energy. Cooling energy end uses decreased $9 \%$; heating end uses increased $6 \%$.

In the ZEB context, the passive solar form measures saved $0.5 \%$ in site energy; cooling end uses were down $6 \%$ and heating end uses were up 4\%. This shift in fuel types leads to a significant improvement in terms of source energy use; net source EUI decreased by $5.6 \mathrm{kBtu} / \mathrm{ft}^{2} \cdot \mathrm{yr}\left(64 \mathrm{MJ} / \mathrm{m}^{2} \cdot \mathrm{yr}\right)$ or $35 \%$.

Figure 4-23 shows how the site EUIs are distributed across the sector. There is a noticeable shift from the Base scenario but little effect at the Max Tech level.

The results for the passive solar scenario are especially difficult to interpret because of the difficulty of devising a one-size-fits-all set of rules for passive solar design. This measure is particularly challenging to implement and model, as it really requires focused attention on each individual building. Form is complicated because good solutions depend on the load profile and the climate and simple rule-based approaches have not been developed that can make proper design decisions. The averaged results hide the magnitude of the impact that form can have because the arbitrary changes sometimes hurt performance. As applied in this study, the passive solar measures actually hurt performance in many buildings and therefore the measures were improperly "designed" with the transformation rules (see Section 3.3.7). Figure 4-24 plots PDFs for the change in EUI rather than the absolute value of EUI. (These distributions are based on a histogram analysis that uses a bin size of $2.0 \mathrm{kBtu} / \mathrm{ft}^{2} \cdot \mathrm{yr}[23$ $\left.\mathrm{MJ} / \mathrm{m}^{2} \cdot \mathrm{yr}\right]$.) This shows that the technical potential for changes in architectural form is especially difficult to assess across the entire sector. Future studies should strive to optimize form for each building based on its type and location. 
Table 4-28 Sector-Wide Average Use Intensity Metrics for Passive Solar Scenarios: IP units

\begin{tabular}{|c|c|c|c|c|c|c|c|}
\hline Use Intensity Metric & $\begin{array}{l}\Phi \\
\mathscr{D} \\
\tilde{D} \\
\infty\end{array}$ & 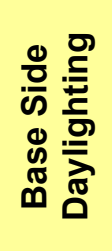 & 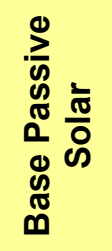 & 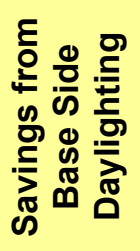 & $\begin{array}{l}\frac{c}{0} \\
\stackrel{d}{-} \\
\underset{x}{\pi} \\
\Sigma\end{array}$ & 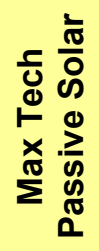 & 总 \\
\hline Total site $\left(\mathrm{kBtu} / \mathrm{ft}^{2} \cdot \mathrm{yr}\right)$ & 70.7 & 68.1 & 67.5 & $1 \%$ & 40.3 & 40.1 & $0.5 \%$ \\
\hline $\mathrm{PV}$ production $\left(\mathrm{kBtu} / \mathrm{ft}^{2} \cdot \mathrm{yr}\right)$ & 0.0 & 0.0 & 0.0 & $0 \%$ & 28.1 & 28.1 & $0 \%$ \\
\hline Net site $\left(\mathrm{kBtu} / \mathrm{ft}^{2} \cdot \mathrm{yr}\right)$ & 70.7 & 68.1 & 67.5 & $1 \%$ & 12.2 & 11.9 & $2.5 \%$ \\
\hline Lights $\left(\mathrm{kBtu} / \mathrm{ft}^{2} \cdot \mathrm{yr}\right)$ & 12.6 & 10.4 & 10.2 & $2 \%$ & 4.5 & 4.5 & $0 \%$ \\
\hline Cooling equipment $\left(\mathrm{kBtu} / \mathrm{ft}^{2} \cdot \mathrm{yr}\right)$ & 9.1 & 8.6 & 7.8 & $9 \%$ & 5.2 & 4.9 & $5.8 \%$ \\
\hline Heating equipment $\left(\mathrm{kBtu} / \mathrm{ft}^{2} \cdot \mathrm{yr}\right)$ & 17.5 & 17.8 & 18.8 & $-6 \%$ & 5.2 & 5.4 & $-3.8 \%$ \\
\hline Fans $\left(\mathrm{kBtu} / \mathrm{ft}^{2} \cdot \mathrm{yr}\right)$ & 4.6 & 4.3 & 3.8 & $12 \%$ & 1.7 & 1.7 & $0 \%$ \\
\hline Pumps (kBtu/ft².yr) & 0.54 & 0.52 & 0.46 & $12 \%$ & 0.38 & 0.36 & $5.3 \%$ \\
\hline $\begin{array}{l}\text { Plug and process electricity } \\
\left(\mathrm{kBtu} / \mathrm{ft}^{2} \cdot \mathrm{yr}\right)\end{array}$ & 10.1 & 10.1 & 10.1 & $0 \%$ & 10.1 & 10.1 & $0 \%$ \\
\hline Process gas $\left(\mathrm{kBtu} / \mathrm{ft}^{2} \cdot \mathrm{yr}\right)$ & 5.3 & 5.3 & 5.3 & $0 \%$ & 5.3 & 5.3 & $0 \%$ \\
\hline Refrigeration (kBtu/ft² $\cdot \mathrm{yr})$ & 4.4 & 4.4 & 4.4 & $0 \%$ & 3.1 & 3.1 & $0 \%$ \\
\hline Service water heating $\left(\mathrm{kBtu} / \mathrm{ft}^{2} \cdot \mathrm{yr}\right)$ & 2.5 & 2.5 & 2.5 & $0 \%$ & 2.3 & 2.3 & $0 \%$ \\
\hline Total site electricity $\left(\mathrm{kBtu} / \mathrm{ft}^{2} \cdot \mathrm{yr}\right)$ & 46.0 & 43.0 & 41.4 & $4 \%$ & 27.9 & 27.5 & $1.4 \%$ \\
\hline Gas (kBtu/ft² $\cdot y r)$ & 24.4 & 24.8 & 25.8 & $-4 \%$ & 12.1 & 12.3 & $-1.7 \%$ \\
\hline Net source $\left(\mathrm{kBtu} / \mathrm{ft}^{2} \cdot \mathrm{yr}\right)$ & 156.7 & 148.5 & 145.1 & $2 \%$ & 16.0 & 10.4 & $35 \%$ \\
\hline Peak electrical demand $\left(\mathrm{W} / \mathrm{ft}^{2}\right)$ & 5.1 & 4.8 & 4.7 & $2 \%$ & 2.5 & 2.5 & $0 \%$ \\
\hline Energy water $\left(\mathrm{gal} / \mathrm{ft}^{2} \cdot \mathrm{yr}\right)$ & 17.7 & 16.5 & 15.9 & $4 \%$ & 7.0 & 6.9 & $1.6 \%$ \\
\hline Energy cost $\left(\$ / \mathrm{ft}^{2} \cdot \mathrm{yr}\right)$ & 1.52 & 1.44 & 1.41 & $2 \%$ & 0.88 & 0.87 & $1.1 \%$ \\
\hline Energy equivalent carbon $\left(\mathrm{lb} / \mathrm{ft}^{2} \cdot \mathrm{yr}\right)$ & 10.2 & 9.6 & 9.4 & $3 \%$ & 4.2 & 3.7 & $11.5 \%$ \\
\hline
\end{tabular}


Table 4-29 Sector-Wide Average Use Intensity Metrics for Passive Solar Scenarios: SI units

\begin{tabular}{|c|c|c|c|c|c|c|c|}
\hline Use Intensity Metric & 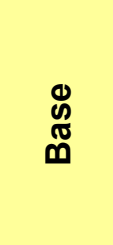 & 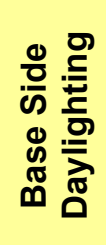 & 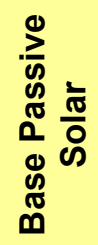 & 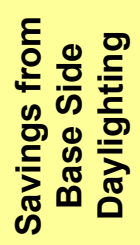 & $\begin{array}{l}\frac{1}{0} \\
\stackrel{0}{上} \\
\times \\
\Sigma \\
\Sigma\end{array}$ & 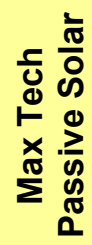 & 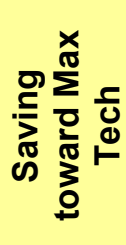 \\
\hline Total site $\left(\mathrm{MJ} / \mathrm{m}^{2} \cdot \mathrm{yr}\right)$ & 803 & 774 & 767 & $1 \%$ & 458 & 456 & $0.5 \%$ \\
\hline $\mathrm{PV}$ production $\left(\mathrm{MJ} / \mathrm{m}^{2} \cdot \mathrm{yr}\right)$ & 0 & 0 & 0 & $0 \%$ & 319 & 319 & $0 \%$ \\
\hline Net site $\left(\mathrm{MJ} / \mathrm{m}^{2} \cdot \mathrm{yr}\right)$ & 803 & 774 & 767 & $1 \%$ & 139 & 135 & $2.5 \%$ \\
\hline Lights $\left(\mathrm{MJ} / \mathrm{m}^{2} \cdot \mathrm{yr}\right)$ & 143 & 118 & 116 & $2 \%$ & 51 & 51 & $0 \%$ \\
\hline Cooling equipment $\left(\mathrm{MJ} / \mathrm{m}^{2} \cdot \mathrm{yr}\right)$ & 103 & 98 & 89 & $9 \%$ & 59 & 56 & $5.8 \%$ \\
\hline Heating equipment $\left(\mathrm{MJ} / \mathrm{m}^{2} \cdot \mathrm{yr}\right)$ & 199 & 202 & 214 & $-6 \%$ & 59 & 61 & $-3.8 \%$ \\
\hline Fans $\left(\mathrm{MJ} / \mathrm{m}^{2} \cdot \mathrm{yr}\right)$ & 52 & 49 & 43 & $12 \%$ & 19 & 19 & $0 \%$ \\
\hline Pumps $\left(\mathrm{MJ} / \mathrm{m}^{2} \cdot \mathrm{yr}\right)$ & 6 & 6 & 5 & $12 \%$ & 4 & 4 & $5.3 \%$ \\
\hline $\begin{array}{l}\text { Plug and process electricity } \\
\left(\mathrm{MJ} / \mathrm{m}^{2} \cdot \mathrm{yr}\right)\end{array}$ & 115 & 115 & 115 & $0 \%$ & 115 & 115 & $0 \%$ \\
\hline Process gas $\left(\mathrm{MJ} / \mathrm{m}^{2} \cdot \mathrm{yr}\right)$ & 60 & 60 & 60 & $0 \%$ & 60 & 60 & $0 \%$ \\
\hline Refrigeration $\left(\mathrm{MJ} / \mathrm{m}^{2} \cdot \mathrm{yr}\right)$ & 50 & 50 & 50 & $0 \%$ & 35 & 35 & $0 \%$ \\
\hline Service water heating $\left(\mathrm{MJ} / \mathrm{m}^{2} \cdot \mathrm{yr}\right)$ & 28 & 28 & 28 & $0 \%$ & 26 & 26 & $0 \%$ \\
\hline Total site electricity $\left(\mathrm{MJ} / \mathrm{m}^{2} \cdot \mathrm{yr}\right)$ & 523 & 489 & 470 & $4 \%$ & 317 & 313 & $1.4 \%$ \\
\hline Gas $\left(\mathrm{MJ} / \mathrm{m}^{2} \cdot \mathrm{yr}\right)$ & 277 & 282 & 293 & $-4 \%$ & 138 & 140 & $-1.7 \%$ \\
\hline Net source $\left(\mathrm{MJ} / \mathrm{m}^{2} \cdot \mathrm{yr}\right)$ & 1,781 & 1,688 & 1649 & $2 \%$ & 182 & 118 & $35 \%$ \\
\hline Peak electrical demand $\left(\mathrm{W} / \mathrm{m}^{2}\right)$ & 55 & 52 & 51 & $2 \%$ & 27 & 27 & $0 \%$ \\
\hline Energy water $\left(\mathrm{I} / \mathrm{m}^{2} \cdot \mathrm{yr}\right)$ & 721 & 672 & 648 & $4 \%$ & 285 & 281 & $1.6 \%$ \\
\hline Energy cost $\left(\$ / \mathrm{m}^{2} \cdot \mathrm{yr}\right)$ & 16.36 & 15.50 & 15.18 & $2 \%$ & 9.47 & 9.36 & $1.1 \%$ \\
\hline Energy equivalent carbon $\left(\mathrm{kg} / \mathrm{m}^{2} \cdot \mathrm{yr}\right)$ & 49.8 & 46.9 & 45.9 & $3 \%$ & 20.5 & 18.1 & $11.5 \%$ \\
\hline
\end{tabular}




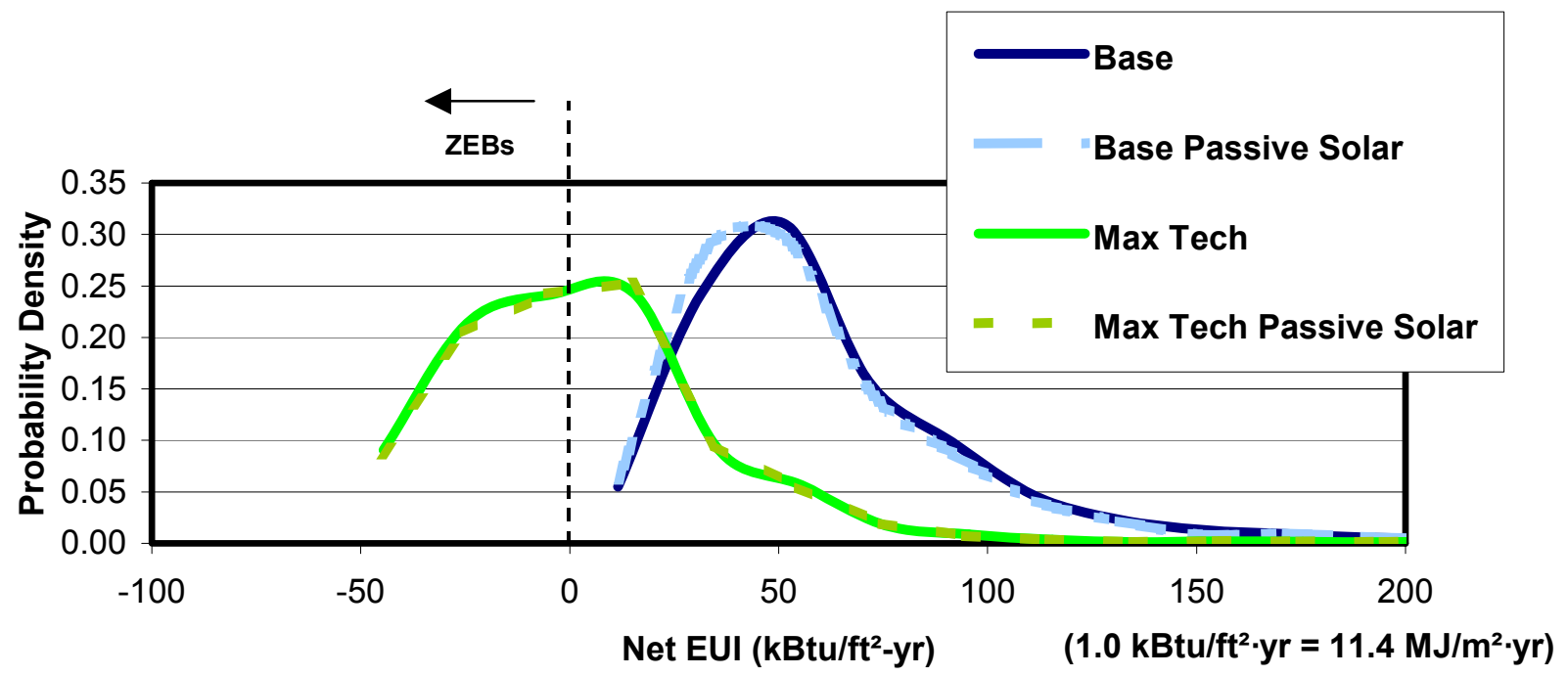

Figure 4-23 PDFs for passive solar scenarios

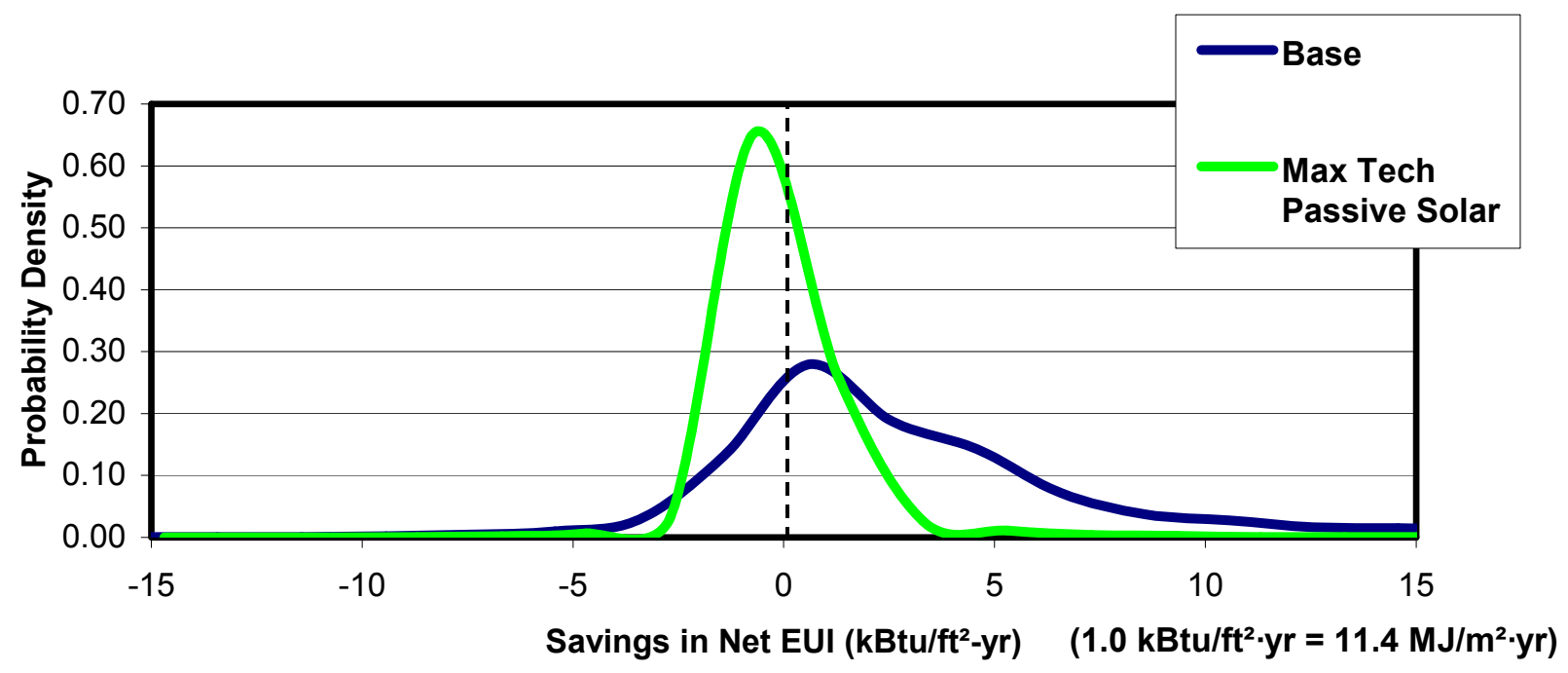

Figure 4-24 PDFs of EUl savings for passive solar scenarios

\subsubsection{Standards}

The modeling results show that 90.1-1999 is 5\% less stringent than 90.1-2004 and proposed Standard $189 \mathrm{P}$ could be $27 \%$ more stringent. Table $4-30$ and Table 4-31 list results for various intensity metrics for all three standards.

The model results indicate that by applying Standard 90.1-2004 instead of Standard 90.1-1999 across the entire sector, EUIs can be lowered by $3.8 \mathrm{kBtu} / \mathrm{ft}^{2} \cdot \mathrm{yr}\left(43 \mathrm{MJ} / \mathrm{m}^{2} \cdot \mathrm{yr}\right)$ or $5 \%$. Standard $90.1-1999$ uses $13 \%$ more electricity and 9\% less natural gas than 90.1-2004. Savings are primarily from lighting where that end use is 33\% higher in 90.1-1999. Heating energy use is higher for 90.1-2004 than for 90.1-1999 because the reduced lighting power decreases internal gains and increases heating loads placed on the HVAC system. The 2004 version tends to shift fuel types from electricity to natural gas; the net effect was that energy costs and source energy were $9 \%$ higher in the 1999 version. Peak electrical demand improved $10 \%$ in the 2004 version. 
The results for proposed Standard 189P show that prescriptive standards can be developed that provide significant performance improvement. The results indicate that measures modeled for one draft of Standard 189P can lower EUIs by $19.8 \mathrm{kBtu} / \mathrm{ft}^{2} \cdot \mathrm{yr}\left(225 \mathrm{MJ} / \mathrm{m}^{2} \cdot \mathrm{yr}\right)$ or $28 \%$. Standard $189 \mathrm{P}$ buildings use $26 \%$ less electricity and $30 \%$ less natural gas. Energy costs are reduced by $27 \%$, net source energy by $18 \%$, and peak electrical demand by $29 \%$.

Figure 4-25 shows how EUIs are distributed across the commercial sector for the three Standards scenarios and compares them to the total and net site EUIs for the Max Tech scenario. The change from 1999 version to 2004 version slightly alters the shape of the distribution curve, but does not shift the peak much. Standard 189P shows broad improvement across the sector with much higher densities of low-EUI buildings.

Table 4-30 Sector-Wide Average Use Intensity Metrics for Standards Scenarios: IP units

\begin{tabular}{|c|c|c|c|c|c|}
\hline \multirow[b]{2}{*}{ Use Intensity Metric } & \multirow{2}{*}{$\begin{array}{c}\text { Base } \\
\text { Standard } \\
90.1-2004 \\
\text { Use Intensity }\end{array}$} & \multicolumn{2}{|c|}{ Standard 90.1-1999 } & \multicolumn{2}{|c|}{ Standard 189P } \\
\hline & & $\begin{array}{c}\text { Use } \\
\text { Intensity }\end{array}$ & $\begin{array}{c}\text { Savings } \\
\text { from } \\
\text { Base }\end{array}$ & $\begin{array}{c}\text { Use } \\
\text { Intensity }\end{array}$ & $\begin{array}{c}\text { Savings } \\
\text { from } \\
\text { Base }\end{array}$ \\
\hline Total site $\left(\mathrm{kBtu} / \mathrm{ft}^{2} \cdot \mathrm{yr}\right)$ & 70.7 & 74.5 & $-5 \%$ & 51.4 & $27 \%$ \\
\hline Net site $\left(\mathrm{kBtu} / \mathrm{ft}^{2} \cdot \mathrm{yr}\right)$ & 70.7 & 74.5 & $-5 \%$ & 50.9 & $28 \%$ \\
\hline Lights $\left(\mathrm{kBtu} / \mathrm{ft}^{2} \cdot \mathrm{yr}\right)$ & 12.6 & 16.7 & $-33 \%$ & 8.3 & $34 \%$ \\
\hline Cooling equipment $\left(\mathrm{kBtu} / \mathrm{ft}^{2} \cdot \mathrm{yr}\right)$ & 9.1 & 10.9 & $-20 \%$ & 6.3 & $31 \%$ \\
\hline Heating equipment $\left(\mathrm{kBtu} / \mathrm{ft}^{2} \cdot \mathrm{yr}\right)$ & 17.5 & 15.2 & $13 \%$ & 10.7 & $39 \%$ \\
\hline Fans $\left(\mathrm{kBtu} / \mathrm{ft}^{2} \cdot \mathrm{yr}\right)$ & 4.6 & 5.0 & $-9 \%$ & 2.4 & $48 \%$ \\
\hline Pumps (kBtu/ft².yr) & 0.54 & 0.56 & $-4 \%$ & 0.48 & $11 \%$ \\
\hline Plug and process electricity $\left(\mathrm{kBtu} / \mathrm{ft}^{2} \cdot \mathrm{yr}\right)$ & 10.1 & 10.1 & $0 \%$ & 9.0 & $11 \%$ \\
\hline Process gas $\left(\mathrm{kBtu} / \mathrm{ft}^{2} \cdot \mathrm{yr}\right)$ & 5.3 & 5.3 & $0 \%$ & 4.7 & $11 \%$ \\
\hline Refrigeration $\left(\mathrm{kBtu} / \mathrm{ft}^{2} \cdot \mathrm{yr}\right)$ & 4.4 & 4.4 & $0 \%$ & 3.9 & $11 \%$ \\
\hline Service water heating $\left(\mathrm{kBtu} / \mathrm{ft}^{2} \cdot \mathrm{yr}\right)$ & 2.5 & 2.5 & $0 \%$ & 2.4 & $4 \%$ \\
\hline Total site electricity $\left(\mathrm{kBtu} / \mathrm{ft}^{2} \cdot \mathrm{yr}\right)$ & 46.0 & 52.1 & $-13 \%$ & 34.0 & $26 \%$ \\
\hline Gas $\left(k B t u / f t^{2} \cdot y r\right)$ & 24.4 & 22.1 & $9 \%$ & 17.1 & $30 \%$ \\
\hline Net source $\left(\mathrm{kBtu} / \mathrm{ft}^{2} \cdot \mathrm{yr}\right)$ & 156.7 & 171.2 & $-9 \%$ & 128.4 & $18 \%$ \\
\hline Peak electrical demand $\left(\mathrm{W} / \mathrm{ft}^{2}\right)$ & 5.1 & 5.6 & $-10 \%$ & 3.6 & $29 \%$ \\
\hline Energy water $\left(\mathrm{gal} / \mathrm{ft}^{2} \cdot \mathrm{yr}\right)$ & 17.7 & 20.2 & $-14 \%$ & 12.8 & $27 \%$ \\
\hline Energy cost $\left(\$ / \mathrm{ft}^{2} \cdot \mathrm{yr}\right)$ & 1.52 & 1.66 & $-9 \%$ & 1.11 & $27 \%$ \\
\hline Energy equivalent carbon $\left(\mathrm{lb} / \mathrm{ft}^{2} \cdot \mathrm{yr}\right)$ & 10.2 & 11.3 & $-11 \%$ & 6.6 & $35 \%$ \\
\hline
\end{tabular}


Table 4-31 Sector-Wide Average Use Intensity Metrics for Standards Scenarios: SI units

\begin{tabular}{|c|c|c|c|c|c|}
\hline \multirow[b]{2}{*}{ Use Intensity Metric } & \multirow{2}{*}{$\begin{array}{c}\text { Base } \\
\text { Standard } \\
90.1-2004 \\
\text { Use Intensity }\end{array}$} & \multicolumn{2}{|c|}{ Standard 90.1-1999 } & \multicolumn{2}{|c|}{ Standard 189P } \\
\hline & & $\begin{array}{c}\text { Use } \\
\text { Intensity }\end{array}$ & $\begin{array}{c}\text { Savings } \\
\text { from } \\
\text { Base }\end{array}$ & $\begin{array}{c}\text { Use } \\
\text { Intensity }\end{array}$ & $\begin{array}{c}\text { Savings } \\
\text { from } \\
\text { Base }\end{array}$ \\
\hline Total site $\left(\mathrm{MJ} / \mathrm{m}^{2} \cdot \mathrm{yr}\right)$ & 803 & 847 & $-5 \%$ & 584 & $27 \%$ \\
\hline Net site $\left(\mathrm{MJ} / \mathrm{m}^{2} \cdot \mathrm{yr}\right)$ & 803 & 847 & $-5 \%$ & 578 & $28 \%$ \\
\hline Lights $\left(\mathrm{MJ} / \mathrm{m}^{2} \cdot \mathrm{yr}\right)$ & 143 & 190 & $-33 \%$ & 94 & $34 \%$ \\
\hline Cooling equipment $\left(\mathrm{MJ} / \mathrm{m}^{2} \cdot \mathrm{yr}\right)$ & 103 & 124 & $-20 \%$ & 72 & $31 \%$ \\
\hline Heating equipment $\left(\mathrm{MJ} / \mathrm{m}^{2} \cdot \mathrm{yr}\right)$ & 199 & 173 & $13 \%$ & 122 & $39 \%$ \\
\hline Fans $\left(\mathrm{MJ} / \mathrm{m}^{2} \cdot \mathrm{yr}\right)$ & 52 & 57 & $-9 \%$ & 27 & $48 \%$ \\
\hline Pumps $\left(\mathrm{MJ} / \mathrm{m}^{2} \cdot \mathrm{yr}\right)$ & 6 & 6 & $-4 \%$ & 5 & $11 \%$ \\
\hline Plug and process electricity $\left(\mathrm{MJ} / \mathrm{m}^{2} \cdot \mathrm{yr}\right)$ & 115 & 115 & $0 \%$ & 102 & $11 \%$ \\
\hline Process gas $\left(\mathrm{MJ} / \mathrm{m}^{2} \cdot \mathrm{yr}\right)$ & 60 & 60 & $0 \%$ & 53 & $11 \%$ \\
\hline Refrigeration $\left(\mathrm{MJ} / \mathrm{m}^{2} \cdot \mathrm{yr}\right)$ & 50 & 50 & $0 \%$ & 44 & $11 \%$ \\
\hline Service water heating $\left(\mathrm{MJ} / \mathrm{m}^{2} \cdot \mathrm{yr}\right)$ & 28 & 28 & $0 \%$ & 27 & $4 \%$ \\
\hline Total site electricity $\left(\mathrm{MJ} / \mathrm{m}^{2} \cdot \mathrm{yr}\right)$ & 523 & 592 & $-13 \%$ & 386 & $26 \%$ \\
\hline Gas $\left(\mathrm{MJ} / \mathrm{m}^{2} \cdot \mathrm{yr}\right)$ & 277 & 251 & $9 \%$ & 194 & $30 \%$ \\
\hline Net source $\left(\mathrm{MJ} / \mathrm{m}^{2} \cdot \mathrm{yr}\right)$ & 1781 & 1945 & $-9 \%$ & 1459 & $18 \%$ \\
\hline Peak electrical demand $\left(\mathrm{W} / \mathrm{m}^{2}\right)$ & 55 & 60 & $-10 \%$ & 39 & $29 \%$ \\
\hline Energy water $\left(\mathrm{I} / \mathrm{m}^{2} \cdot \mathrm{yr}\right)$ & 721 & 823 & $-9 \%$ & 522 & $27 \%$ \\
\hline Energy cost $\left(\$ / \mathrm{m}^{2} \cdot \mathrm{yr}\right)$ & 16 & 18 & $-9 \%$ & 12 & $27 \%$ \\
\hline Energy equivalent carbon $\left(\mathrm{kg} / \mathrm{m}^{2} \cdot \mathrm{yr}\right)$ & 50 & 55 & $-11 \%$ & 32 & $35 \%$ \\
\hline
\end{tabular}




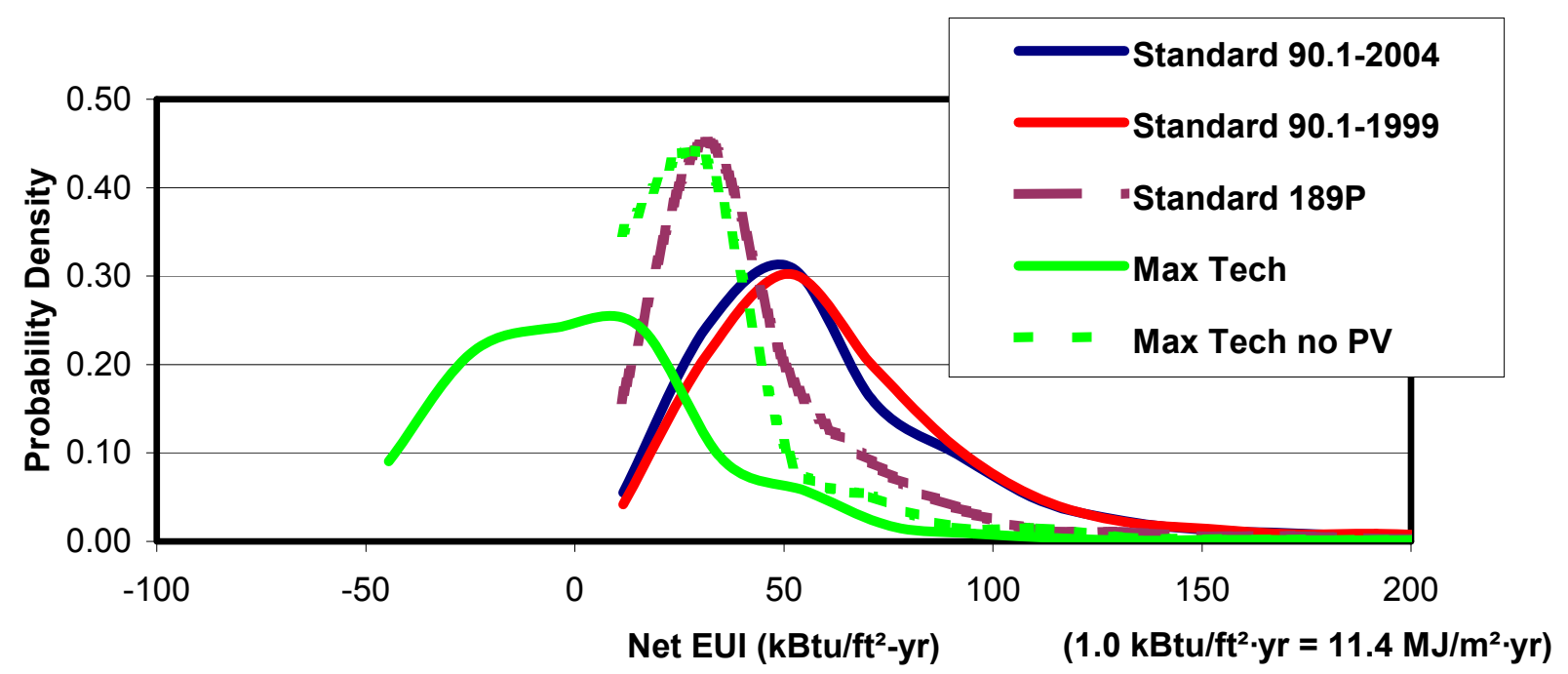

Figure 4-25 PDFs for Standards scenarios 


\section{RECOMMENDATIONS AND FUTURE RESEARCH}

We found BT's ZEB goal to be technically achievable for large portions of the commercial building sector and recommend that it be pursued. This recommendation is based on rigorous analysis and EnergyPlus modeling of an exhaustive array of data contained in the 2003 CBECS (EIA 2006).

Our analysis shows not only that segments of the sector can achieve zero energy consumption, but also that they can become net energy producers. This means that some commercial buildings could produce enough electricity on site to meet their own demands and export surplus electricity to the utility grid. Thus, we recommend that the ZEB goal be formulated for new construction in the sector as a whole so that subsectors that produce more energy than they consume, such as warehousing, effectively offset the energy consumed by portions of the sector that cannot achieve ZEB.

Efforts to promote successful ZEBs in real-world projects should focus on single-story buildings with plug and process EUIs less than $10 \mathrm{kBtu} / \mathrm{ft}^{2} \cdot \mathrm{yr}\left(110 \mathrm{MJ} / \mathrm{ft}^{2} \cdot \mathrm{yr}\right)$. Single-story buildings offer advantages over multistory buildings because they have a large roof area per usable floor area and can be completely daylit (see Figure 4-6).

We selected the research methods to allow for modeling of the entire U.S. sector with a diverse range of building activities and locations. EnergyPlus is used to simulate the complex interactions between weather, systems that use energy, and energy design measures. The resulting model properly reflects the cumulative and interactive effects of many energy-saving and -producing measures rather than a simple summation of individual savings.

\subsection{Critical Review and Improvement of Method}

Using a large population of buildings based on the 2003 CBECS to model the commercial sector has advantages and disadvantages. A main advantage is that directly using the statistical data set encourages confidence in the results because they could be expected to properly reflect the entire sector. This mitigates a common difficulty in interpreting simulation results when trying to understand the implications for the entire nation from results for a small number of buildings in a handful of locations.

A main disadvantage of this method is that the large number of models increases computing requirements, which precludes the evaluation of large numbers of scenarios with different technologies and practices. This study demonstrated that although using this method is possible, it is also challenging, as it requires considerable computing resources. This study points to the fundamental tension between modeling the national implications of technologies and practices and modeling a large number of options. With current computing capabilities, for instance, the total number of simulations needs to be kept reasonably low (about 100,000). The tension here can be somewhat alleviated with supercomputing and mass data storage resources, but the issue will persist because the number of models tends to grow geometrically. As a result, we recommend this approach for future analyses when the results must properly reflect the national implications and when only a limited number of scenarios must be investigated. However, more efficient methods for sector-wide modeling are needed so researchers can investigate more scenarios with different technologies and practices (parametric input perturbations). We recommend developing a relatively small set of benchmark buildings (about 200).

Another important disadvantage of using 2003 CBECS is that this statistical data set is for existing buildings rather than new construction. Data for new construction are available from vendors (e.g., McGraw-Hill's Dodge data) or can be modeled from U.S. Commerce Department data on construction activity. Researchers who plan to model nationwide new construction for this sector should consider purchasing such data rather than assuming that distribution of new construction reflects present stock.

The methodology used here focuses on the technical potential of just the commercial buildings. The analysis does not extend beyond the control volumes of buildings (formed by the thermal envelope of 
each building). Many technical issues outside the buildings, which will affect the true technical potential, are not addressed in this analysis. For example, expanding the manufacturing capacities for various component technologies (such as PV modules or HRVs) that would be needed for the widespread penetrations modeled here may not be practical. Or for example, the annualized "net" definition used for ZEB essentially uses the electrical grid for seasonal storage, but the current grid would not necessarily support widespread deployment of ZEBs. The electrical grid would likely require significant changes to accommodate large numbers of ZEBs exporting significant amounts of PV power without having to spill excess PV power during times of peak production. (Future research efforts should combine the electrical load changes with utility-scale production and dispatch modeling to better understand how the electricity exported by ZEBs will affect the grid.)

The features included in the scenarios are somewhat arbitrary, and other choices could have been made that might improve the study. This study's use of large numbers of EnergyPlus models enabled us to refine each model for each scenario; still, the models could be improved in many areas. Although EnergyPlus offers the opportunity to expand model detail almost without end, the Assessment models could be improved in several high-priority areas in any follow-on study, including:

- The Max Tech scenarios used the same topology for HVAC systems as assigned by Standard 90.1-2004, Appendix G. Completely different topologies such as ground source heat pumps and complex heat recovery designs were not included in the study. The current study relies on simplified topologies, autosizing, and default performance curves to expedite modeling HVAC systems for all types and sizes of commercial buildings. The ability to substitute and compete different HVAC systems would be a major improvement to the methodology. However, this is more challenging than might be casually assumed and would require substantial resources to implement. To compete one type of HVAC system against another via modeling requires that each system be designed in more detail so that part load and off-rating point operations are realistic in each. This requires selecting and sizing individual components and providing realistic performance data, which are usually not available from manufacturers. A long list of candidate HVAC topologies could be investigated.

- Model inputs for HVAC component models could be improved. The COP values for DX coils need to be revisited, because the values are too low for modeling that does not include the supply fan. There are also difficulties that need to be addressed in determining COP values from values specified as seasonal energy efficiency ratio. Fan and pump efficiencies are too high and input data need to be revamped. (For systems numbered 1, 2, 3, 4, 5, and 6, the too high fan efficiencies are roughly compensated for by the too low COP values in the modeling.) Variablespeed fans need performance curves developed for better modeling of off-rated conditions. Fan and pump static pressures should vary with building size and HVAC system topology. The addition of HRV will increase static pressures in the Max Tech scenarios; the input data do not reflect this well. The modeling should allow for both HRVs and oversized outside air systems for economizing.

- The Max Tech scenarios used high-performance dynamic glazing systems with a clear state SHGC of 0.45. This is appropriate for many commercial buildings, but some will be much more heating dominated and may benefit from higher values for SHGC on all south-facing windows for passive solar design. Improved control schemes are needed within EnergyPlus. Once automated search techniques are available, they should be used to make better glazing selections as a function of whole-building performance.

- The PV modeling was decoupled from the heat transfer modeling. EnergyPlus offers building integrated PV (BIPV) modeling so the impact of PV panels on building envelope loads can be properly modeled. The analysis framework should be expanded to use BIPV models to better account for the system interactions between the PV modules and the roof (shading and electricity export). 
- All buildings were modeled with a five per floor thermal zoning pattern. Smaller floor plates would not have five separate thermal zones and should be modeled with more suitable thermal zoning patterns.

- The Passive Solar scenarios are based on a fixed set of rules. The rules could be expanded to adjust transformations to be sensitive to results from the basis models for heating, cooling, and lighting energy end uses. Thermal mass increases could also be explored.

\subsection{Comparing Technologies and Practices}

No single technology area is capable of the dramatic improvements in efficiency needed to reach the ZEB goal for large portions of the sector. The results of the individual technology perturbations are far below the improvements from collections of multiple technologies in the Max Tech and Standard 189P scenarios. Although collections of technologies will be needed, this study offers an opportunity to compare individual technologies and practices to each other in an effort to understand their relative potential for contributing to meeting the ZEB goal across the entire sector. Table 5-1 lists key results from Section 4.4 to facilitate comparing different technologies.

In the context of current practice, the potential to reduce site EUI is highest for HVAC followed by lighting, dynamic windows, insulation, plug and process loads, daylighting, and passive solar, in order.

In the ZEB context, the order of importance shifts around with the highest potential to reduce net site EUI being insulation followed by lighting, plug and process loads, HVAC, dynamic windows, daylighting, and passive solar, in order. If we examine the potential to reduce net source EUI rather than site EUI, the highest potential is for plug and process loads followed by lighting, insulation, HVAC, dynamic windows, passive solar, and daylighting. Alternatively, if we examine the potential to reduce peak electrical power demand, the highest potential is for insulation followed by lighting, HVAC, dynamic windows, and plug and process loads. Daylighting and passive solar both showed negligible reductions in peak demand in the ZEB context (but the context of current practice, daylighting showed up to an $8 \%$ decrease in peak power).

Table 5-1 Comparison of Impact of Individual Technology Areas across the Sector

\begin{tabular}{|c|c|c|c|c|}
\hline Technology Area & $\begin{array}{l}\text { EUI Decrease } \\
\text { at Base } \\
\mathrm{kBtu} / \mathrm{ft}^{2} \cdot \mathrm{yr} \\
\left(\mathrm{MJ} / \mathrm{m}^{2} \cdot \mathrm{yr}\right)\end{array}$ & $\begin{array}{c}\text { Net EUI Decrease } \\
\text { at Max Tech } \\
\mathrm{kBtu} / \mathrm{ft}^{2} \cdot \mathrm{yr} \\
\left(\mathrm{MJ} / \mathrm{m}^{2} \cdot \mathrm{yr}\right)\end{array}$ & $\begin{array}{c}\text { Net Source EUI } \\
\text { Decrease at Max } \\
\text { Tech } \\
\mathrm{kBtu} / \mathrm{ft}^{2} \cdot \mathrm{yr} \\
\left(\mathrm{MJ} / \mathrm{m}^{2} \cdot \mathrm{yr}\right)\end{array}$ & $\begin{array}{l}\text { Peak Electrical } \\
\text { Power Decrease } \\
\text { at Max Tech } \\
\text { W/ft }{ }^{2}\left(\mathrm{~W} / \mathrm{m}^{2}\right)\end{array}$ \\
\hline Lighting & $6.8(77)$ & $5.4(61)$ & $15.7(178)$ & $0.5(5.4)$ \\
\hline Daylighting & $3.7(42)$ & $0.8(9)$ & $3.3(37)$ & $0.0(0.0)$ \\
\hline Dynamic Windows & $5.3(60)$ & $3.5(40)$ & $6.6(75)$ & $0.4(4.3)$ \\
\hline Insulation & $4.9(56)$ & $7.9(90)$ & $10.4(118)$ & $0.7(7.5)$ \\
\hline HVAC & $8.2(93)$ & $5.1(58)$ & $8.0(91)$ & $0.5(5.4)$ \\
\hline Passive Solar & $3.2(36)$ & $0.3(3.4)$ & $5.6(64)$ & $0.0(0.0)$ \\
\hline Plug and process loads & $4.4(50)$ & $4.9(56)$ & $17.6(200)$ & $0.2(0.0)$ \\
\hline
\end{tabular}

These results suggest that ZEB research programs should focus on improving thermal insulation, lighting equipment, plug and process loads, and HVAC components. The results for daylighting and passive solar technologies may seem counterintuitive, and to a great extent are due to the assumptions in this study. We purposely accepted the overall geometrical composition of the existing commercial building stock as represented in the CBECS data. Except in special cases, we did not change geometries or orientations to best accommodate such strategies as daylighting, natural ventilation, passive solar heating, and passive solar load avoidance. Thus, R\&D in these areas should not be neglected because the potential for these 
strategies may be underestimated in this study. Also, some technical risk is associated with the possibility of not achieving the high luminous efficacies needed to attain BT goals for advanced lighting technology. Essentially no risk is associated with good daylighting designs, once the geometric implications are accepted.

The results listed in Table 5-1 for individual technology areas cannot be simply summed to model the combined effect of multiple technologies because there are complex interactions between them. This requires integrated system analysis which tends to predict lower levels of energy performance that do simpler analyses. The current results can be used to help quantify the importance of doing integrated systems analysis (based on EnergyPlus) by comparing Table 5-1 to earlier tables such as Table 4-1 or Table 4-26. In Table 5-1, each row represents the weighted average for the energy performance implications of one technology area. The first six rows, when combined, include all the same technologies as the Max Tech scenario and all seven rows combined are the same as the Max Tech High Appliance scenario. For the Max Tech scenario, the integrated modeling result for EUI decrease is 5.5\% lower that the simple sum of technology areas with a composite EUI decrease of $30.4 \mathrm{kBtu} / \mathrm{ft}^{2} \cdot \mathrm{yr}(345$ $\left.\mathrm{MJ} / \mathrm{m}^{2} \cdot \mathrm{yr}\right)$ versus $32.1 \mathrm{kBtu} / \mathrm{ft}^{2} \cdot \mathrm{yr}\left(365 \mathrm{MJ} / \mathrm{m}^{2} \cdot \mathrm{yr}\right)$. For the Max Tech High Appliance scenario the integrated modeling result is $3.4 \%$ lower with a EUI decrease of $35.3 \mathrm{kBtu} / \mathrm{ft}^{2} \cdot \mathrm{yr}\left(401 \mathrm{MJ} / \mathrm{m}^{2} \cdot \mathrm{yr}\right)$ versus $36.5 \mathrm{kBtu} / \mathrm{ft}^{2} \cdot \mathrm{yr}\left(415 \mathrm{MJ} / \mathrm{m}^{2} \cdot \mathrm{yr}\right)$ for the simple sum.

\subsection{Follow-On Analyses of Current Results}

Because of the large number of simulations $(115,680)$ and the use of EnergyPlus, an enormous quantity of data - which could be further analyzed - was produced. This report could address only a small portion of the wide array of analyses that could be conducted with the available data. We recommend that the modeling results be made available for collaborative research with other analysts who may be able to use some of the data, but do not have the resources to do a similar modeling study.

\subsection{Benchmarking}

This study showed the need for a smaller set of representative building models (benchmarks) to use in modeling the sector rather than the full set of buildings from CBECS public use data. Research methods that might suffice for assessing energy consumption of buildings should be revisited to ensure they are sensitive to the solar energy production in the context of ZEB analyses. At the beginning of this project, the intent was to use benchmark building definitions developed by Huang and Franconi (1999). During the pilot phase, however, we determined that their set of models for the sector model did not meet the needs for ZEB analyses because it did not capture the variation in the number of floors in buildings, which has a large impact on reaching the ZEB goal (see Figure 4-6). Another issue that is common for efficiency-oriented analyses is that the selection of modeling locations ignores significant differences in the solar resources (which are based largely on HDD and CDD).

Developing a set of high-quality benchmarks to use in modeling the commercial sector involves at least two distinct activities. The first is to develop standardized ways of defining all the detail needed for a detailed engineering model like EnergyPlus. This effort could be labeled "benchmarking" and requires understanding the physics of how commercial buildings are being built and operated and how to best model them in EnergyPlus. The second activity is to determine the exact set of benchmarks that can model the sector and to develop unique weighting factors for each benchmark. This effort involves choosing the number of benchmarks and requires an understanding of the interactions of geography, climate, and real estate development patterns. Beyond showing that a smaller set is needed, the results of

this study could also be analyzed during the development of such a set if the 2003 CBECS is considered a suitable basis for developing a sector model.

\subsection{Technologies and Practices Perturbations}

There are endless scenarios for ZEB technologies and practices. Parametric simulations can characterize technologies and practices, but there are also difficulties in applying the method because the number of 
simulations grows geometrically. Once a set of benchmark building definitions is available, parametric studies can be used to investigate technology and practices more thoroughly. Developing methods for presenting perturbation analysis and results in ways that are easily understood by those who are unfamiliar with the application of building energy simulation is also necessary.

\subsection{Costs and Optimization}

At the start of this project, we had hoped to be able to assess cost implications along with technically achievable performance levels. Cost modeling was included during the pilot phase on one building type in one location. For the broad study, however, assembling cost data for the whole sector was prohibitive. Collecting adequate data on costs is a serious barrier to conducting such analyses on a wide scale and was beyond the scope of this project.

Another important finding of the cost modeling we did in the pilot study phase was the necessity of including techniques that search for optimal cost and performance levels in the research methodology. Costs need optimization and optimization needs costs. Presenting cost results for only very aggressive scenarios (with ample PV power) rather than for the whole range of possibilities between the minimum standard and the maximum technical potential scenario may be counterproductive and misleading. Analysis methods need to be based on search techniques to identify the lowest cost scenarios. Separate research efforts on search methods are under way to provide this capability, and comprehensive cost and performance data need to be collected for the project. Once optimization-based analysis capabilities are available, they could be used with a small set of representative benchmark buildings to reassess the opportunities for ZEB with economics included in the analysis. Optimization could also be used to identify better energy performance than in the current study (which used relatively fixed packages) because it would be able to tune the set of technologies and practices for individual buildings and locations.

\subsection{Market Penetration}

In this study, we did not attempt to analyze or model market penetration scenarios, nor did we attempt to make detailed projections for how the sector might evolve over the next 20 years. Instead, the research focused on developing detailed engineering models. Future research should attempt to couple the engineering models in EnergyPlus (and cost/performance analyses based on optimization) with market penetration and economic models to develop quantitative results that can generate information on the market viability of ZEBs. One long-term goal for such research would be to couple EnergyPlus-based scenario analyses with other models such as Markal (Seebregts et al. 2001) or the National Energy Modeling System (EIA 2003b). This is needed so that, for example, future AEO reports could include scenarios that reflect the potential for declining EUI found in this assessment (rather than the nearly constant commercial EUIs modeled for AEO 2007). Such research needs to focus on the interactions between energy-performance opportunities and the basis for the decisions made by key players. 


\section{BIBLIOGRAPHY}

ASHRAE. (1999). ANSI/ASHRAE/IESNA Standard 90.1-1999: Energy Standard for Buildings Except Low-Rise Residential Buildings. Atlanta, GA: ASHRAE.

ASHRAE. (2001a). ANSI/ASHRAE/IESNA Standard 90.1-2001: Energy Standard for Buildings Except Low-Rise Residential Buildings. Atlanta, GA: ASHRAE.

ASHRAE. (2001b). 2001 ASHRAE Handbook: Fundamentals. Chapter 29, Table 12, "Plug Loads." Atlanta, GA: ASHRAE.

ASHRAE. (2004a). ANSI/ASHRAE/IESNA Standard 90.1-2004: Energy Standard for Buildings Except Low-Rise Residential Buildings. Atlanta, GA: ASHRAE.

ASHRAE. (2004b). ANSI/ASHRAE Standard 140-2004: Standard Method of Test for the Evaluation of Building Energy Analysis Computer Programs. Atlanta, GA: ASHRAE.

ASHRAE. (2007). BSR/ASHRAE/USGBC/IESNA Standard 189P: Standard for the Design of HighPerformance Green Buildings Except Low-Rise Residential Buildings. Atlanta, GA: ASHRAE. First Public Review Draft (May 2007).

Barley, D., M. Deru, S. Pless, and P. Torcellini. (2005). Procedure for Measuring and Reporting Commercial Building Energy Performance. Golden, CO: NREL/TP-550-38601.

Briggs, R.S.; Crawley, D.B.; Schliesing, J.S. (1992). Energy Requirements for Office Buildings, Volume 1, Existing Buildings. GRI-90/0236.1, February. Chicago: Gas Research Institute (GRI).

Briggs, R. S., Crawley, D.B.; Belzer, D.B. (1987). Analyses and Categorization of the Office Building Stock. GRI-87/0244, October. Chicago: GRI.

CEC. (2006). California Commercial End-Use Survey. March 2006. California Energy Commission. CEC-400-2006-005.

Colliver, D.G. (1995). Energy Requirements for Conditioning of Ventilating Air. Technical Note AIVC 47. Air Infiltration and Ventilation Centre, Coventry, UK.

Crawley, D.B.; Schliesing, J.S. (1992). Energy Requirements for Office Buildings, Volume 2, Recent and Future Buildings. GRI-90/0236.2, March. Chicago: GRI.

Crawley, D.B., Lawrie, L.K.; Winkelmann, F.C.; Buhl, W.F.; Huang, Y.J.; Pedersen, C.O.; Strand, R.K.; Liesen, R.K.; Fisher, D.E.; Witte, M.J.; Glazer, J. (2001). "EnergyPlus: Creating a New-Generation Building Energy Simulation Program." Energy and Buildings 33: 319-331. Amsterdam: Elsevier Science.

Deru, M. and Torcellini, P. (2007). Source Energy and Emission Factors for Energy Use in Buildings. Golden, CO: NREL/TP-550-38617. Revised June 2007.

Deru, M.; Torcellini, P.; Pless, S. (2005a). Energy Design and Performance Analysis of the BigHorn Home Improvement Center. www.nrel.gov/docs/fy05osti/34930.pdf. Technical Report NREL/TP-55034930. Golden, CO: National Renewable Energy Laboratory, 120 pp.

Deru, M.; Torcellini, P.; Sheffer, M.; Lau, A. (2005b). Analysis of the Design and Energy Performance of the Pennsylvania Department of Environmental Protection Cambria Office Building. www.nrel.gov/ docs/fy05osti/34931.pdf. Technical Report NREL/TP-550-34931. Golden, CO: National Renewable Energy Laboratory, $85 \mathrm{pp}$.

DOE. (2000). High-Performance Commercial Buildings: A Technology Roadmap. Washington, DC: DOE. Available from www.eere.energy.gov/buildings/documents/pdfs/roadmap lowres.pdf. 
DOE. (2002). U.S. Lighting Market Characterization Volume 1: National Lighting Inventory and Energy Consumption Estimate. Washington, DC. DOE. Available from www.eere.energy.gov/buildings/info/documents/pdfs/lmc voll final.pdf.

DOE. (2004). Buildings Energy Databook. Washington, DC: DOE. Available from http://buildingsdatabook.eren.doe.gov/.

DOE. (2005a). DOE Solar Energy Technologies Program FY2004 Annual Report. Washington DC:

DOE. Available from www.osti.gov/bridge.

DOE. (2007). Building Technologies Program: Planned Program Activities for 2007-2012. Washington DC: DOE. Updated January 2007. http://www.eere.energy.gov/buildings/about/mypp.html.

EIA. (1983). Nonresidential Buildings Energy Consumption Survey: 1979 Consumption and Expenditures, Part 1: Natural Gas and Electricity. DOE/EIA-0318/1. Washington, DC: EIA.

EIA. (1995). Commercial Buildings Consumption and Expenditures 1992. DOE/EIA-0318(92). Washington, DC: EIA.

EIA. (1998). A Look at Commercial Buildings in 1995: Characteristics, Energy Consumption, and Energy Expenditures. Washington, DC: EIA. Available from www.eia.doe.gov/emeu/cbecs/report_1995.html.

EIA. (2002). 1999 Commercial Buildings Energy Consumption Survey. Washington, DC: EIA. Available from www.eia.doe.gov/emeu/cbecs/1999publicuse/99microdat.html.

EIA. (2003a). End-Use Consumption by Principal Building Activity, 1999 (Preliminary Estimates). Washington, DC: EIA. Available from www.eia.doe.gov/emeu/cbecs/enduse consumption/pba.html

EIA. (2003b). National Energy Modeling System: An Overview 2003. Washington, DC: EIA. DOE/EIA-0581(2003). Available from www.eia.doe.gov/oiaf/aeo/overview/

EIA. (2006). 2003 Commercial Buildings Energy Consumption Survey. Washington, DC: EIA. Available from www.eia.doe.gov/emeu/cbecs/cbecs2003/introduction.html.

EIA. (2007). Annual Energy Outlook 2007. Energy Information Administration Washington, DC: EIA. Available from http://www.eia.doe.gov/oiaf/aeo.

EPA. (2003). U.S. EPA eGRID2002 Version 2.01. May 2003. Washington, DC: EPA.

Fisk, W.J. (2000). Health and Productivity Gains from Better Indoor Environments and Their Implications for the U.S. Department of Energy. Lawrence Berkeley National Laboratory. Berkeley, CA. LBNL-47458.

GARD Analytics. (2004a). EnergyPlus Testing with ANSI/ASHRAE Standard 140-2001 (BESTEST). EnergyPlus Version 1.2.0.029. Park Ridge, IL: GARD. Available from www.energyplus.gov.

GARD Analytics. (2004b). EnergyPlus Testing with HVAC BESTEST Part 1-Tests E100 to E200. EnergyPlus Version 1.2.0.029. Park Ridge, IL: GARD. Available from www.energyplus.gov.

Griffith, B.; N. Long; P. Torcellini; R. Judkoff; D. Crawley, J. Ryan. (2008). Methodology for Modeling Building Energy Performance Across the Commercial Sector. NREL Report No. TP-550-41956. Golden, CO: NREL.

Griffith, B.; D. Crawley. (2006). Methodology for Analyzing the Technical Potential for Energy Performance in the U.S. Commercial Buildings Sector with Detailed Energy Modeling. Proceedings of SimBuild 2006 Conference, Cambridge, MA. NREL Report No. CP-550-40124. Golden, CO: NREL.

Griffith, B.; Deru, M.; Torcellini, P.; Ellis, P. (2005). Analysis of the Energy Performance of the Chesapeake Bay Foundation's Philip Merrill Environmental Center. www.nrel.gov/docs/ fy05osti/34830.pdf. Technical Report NREL/TP-550-34830. Golden, CO: National Renewable Energy Laboratory, $145 \mathrm{pp}$. 
Huang, J.; Franconi, E. (1999). Commercial Heating and Cooling Loads Component Analysis. Berkeley, CA: Lawrence Berkeley National Laboratory.

Judkoff, R.; Neymark, J. (1995). International Energy Agency Building Energy Simulation Test (BESTEST) and Diagnostic Method. NREL Report No. TP-472-6231. Golden, CO: NREL.

Litzkow, M.; Livny, M.; Mutka, M. (1998). “Condor-A Hunter of Idle Workstations.” Proceedings of the 8th International Conference of Distributed Computing Systems. Washington, DC: IEEE; pp. 104111.

Lomas, K.J.; Eppel, H. (1992). Sensitivity Analysis Techniques for Building Thermal Simulation Programs. Energy and Buildings 19:21-44. Amsterdam: Elsevier Science.

MacDonald, I.A. (2002). Quantifying the Effects of Uncertainty in Building Simulation. Ph.D. Thesis. Glasgow, UK: University of Strathclyde.

Marion, W.; Wilcox, S. (1995). Solar Radiation Data Manual for Buildings. NREL/TP-463-7904.

Golden, CO: NREL.

Moffat, S. (2001). Stock Aggregation: Methods for Evaluation the Environmental Performance of

Building Stocks. Background report from the International Energy Agency's Annex 31 Energy-Related Environmental Impact of Buildings. Available from www.annex31.com/.

Neymark, J.; Judkoff, R. (2002). International Energy Agency Building Energy Simulation Test and Diagnostic Method for Heating, Ventilating, and Air-Conditioning Equipment Models (HVAC BESTEST); Volume 1: Cases E100-E200. NREL/TP-550-30152. Golden, CO: NREL.

NREL. (2000). Photovoltaics—Energy for the New Millennium: The National Photovoltaics Program Plan, 2000-2004. (2000). 22 pp.; NREL Report No. BR-520-25847; DOE/GO-10099-940.

Orme, M. (2001). "Estimates of the Energy Impact of Ventilation and Associated Financial Expenditures." Energy and Buildings 33:199-205. Amsterdam: Elsevier Science.

Persily, A.K. (1998) Airtightness of Commercial and Institutional Buildings: Blowing Holes in the Myth of Tight Buildings. DOE,ASHRAE, ORNL Conference - Thermal Envelopes VII, Clear Water, FL.

Pless, S.; Torcellini, P. (2005). Energy Performance Evaluation of a Low-Energy Academic BuildingAdam Joseph Lewis Center for Environmental Studies, Oberlin College, Oberlin, Ohio.

www.nrel.gov/docs/fy05osti/33180.pdf. Technical Report NREL/TP-550-33180. Golden, CO: National Renewable Energy Laboratory, $150 \mathrm{pp}$.

Reed, J.H.; Johnson, K.; Riggert, J.; Oh, A.D. (2004). Who Plays and Who Decides: The Structure and Operation of the Commercial Building Market. Rockville, MD: Innovologie LLC.

Roth, K.W.; Goldstein, F.; Kleinman, J. (2002). Energy Consumption by Office and Telecommunications Equipment in Commercial Buildings. Volume I: Energy Consumption Baseline. Cambridge, MA: Arther D. Little, Inc.

Roth, K.W.; Larocque, G.R.; Kleinman, J. (2004). Energy Consumption by Office and Telecommunications Equipment in Commercial Buildings. Volume II: Energy Savings Potential. Cambridge, MA: TIAX LLC.

Sachs, H.; Nadel, S.; Thorne Amann, J.; Tuazon, M.; Mendelsohn, E.; Rainer, L.; Todesco, G.; Shipley, D.; Adelaar, M. (2004). Emerging Energy-Saving Technologies and Practices for the Building Sector as of 2004. Washington, DC: American Council for an Energy-Efficient Economy.

Seebregts, A.J.; Goldstein, G.A.; Smekens, K. (2001). Energy/Environment Modeling with the MARKAL Family of Models. Proceedings of the OR2001 Conference, Sept 3-5, 2001, Duisburg, Germany. Available from www.etsap.org/reports/markal.html 
Seppanen, O.A., Fisk, W.J., Mendell, M.J. (1999). Association of ventilation rates and $\mathrm{CO}_{2}$ concentrations with health and other responses in commercial and institutional buildings. Indoor Air 1999: 9: 226-252.

Taylor, J.R. (1982). An Introduction to Error Analysis. Mill Valley, CA: University Science Books.

Torcellini, P.; Long, N.; Pless, S.; Judkoff, R. (2005a). Evaluation of the Low-Energy Design and Energy Performance of the Zion National Park Visitor Center. www.nrel.gov/docs/fy05osti/34607.pdf. Technical Report NREL/TP-550-34607. Golden, CO: National Renewable Energy Laboratory, 156 pp.

Torcellini, P.; Pless, S.; Griffith, B.; Judkoff, R. (2005b). Evaluation of the Energy Performance and Design Process of the Thermal Test Facility at the National Renewable Energy Laboratory. www.nrel.gov/docs/fy05osti/34832.pdf. Technical Report NREL/TP-550-34832. Golden, CO: National Renewable Energy Laboratory, $144 \mathrm{pp}$.

Torcellini, P.; Long, N.; Judkoff, R. (2004). "Consumptive Water Use for U.S. Power Production." ASHRAE Transactions 2003 (110:1). Also NTEL/CP-550-35190.

Torcellini, P.; Pless, S.; Deru, M.; Crawley, D. (2006). "Zero Energy Buildings: A Critical Look at the Definition; Preprint." NREL Report No. CP-550-39833.

Torcellini, P. (2001). “Better Buildings by Design.” Solar Today (March/April 2001).

Turk, B.H., Grimsrud, D.T., Brown, J.T., Geisling-Sobotka, K.L., Harrison, J., and Prill, R.J. (1989).

Commercial Building Ventilation Rates and Particle Concentrations. ASHRAE Transactions 95(1):422433. Atlanta, GA: ASHRAE. 


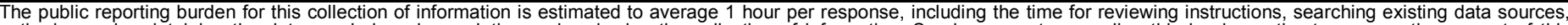

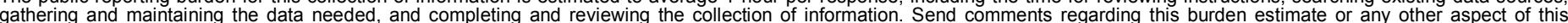

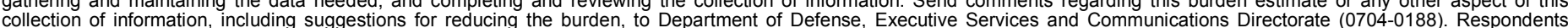

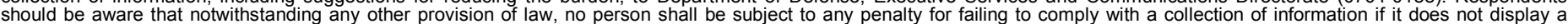

should be aware that notwithstanding

PLEASE DO NOT RETURN YOUR FORM TO THE ABOVE ORGANIZATION.

\begin{tabular}{l|l|l|l} 
1. REPORT DATE $(D D-M M-Y Y Y Y)$ & 2. & REPORT TYPE & 3. DATES COVERED (FrOm - TO)
\end{tabular}

December 2007

Technical Report

4. TITLE AND SUBTITLE

Assessment of the Technical Potential for Achieving Net Zero-

Energy Buildings in the Commercial Sector 5a. CONTRACT NUMBER

DE-AC36-99-G010337

5b. GRANT NUMBER

5c. PROGRAM ELEMENT NUMBER

5d. PROJECT NUMBER

NREL/TP-550-41957

5e. TASK NUMBER

BEC71006

5f. WORK UNIT NUMBER
7. PERFORMING ORGANIZATION NAME(S) AND ADDRESS(ES)

National Renewable Energy Laboratory

1617 Cole Blvd.

Golden, CO 80401-3393
8. PERFORMING ORGANIZATION REPORT NUMBER

NREL/TP-550-41957

9. SPONSORING/MONITORING AGENCY NAME(S) AND ADDRESS(ES)

10. SPONSOR/MONITOR'S ACRONYM(S) NREL

11. SPONSORING/MONITORING AGENCY REPORT NUMBER

12. DISTRIBUTION AVAILABILITY STATEMENT

National Technical Information Service

U.S. Department of Commerce

5285 Port Royal Road

Springfield, VA 22161

13. SUPPLEMENTARY NOTES

14. ABSTRACT (Maximum 200 Words)

This report summarizes the findings from research conducted at NREL to assess the technical potential for zeroenergy building technologies and practices to reduce the impact of commercial buildings on the U.S. energy system. Commercial buildings currently account for $18 \%$ of annual U.S. energy consumption, and energy use is growing along with overall floor area. Reducing the energy use of this sector will require aggressive research goals and rapid implementation of the research results.

15. SUBJECT TERMS

zero-energy building; assessment; commercial building; building technology

\begin{tabular}{l}
\hline \multicolumn{3}{|c|}{ 16. SECURITY CLASSIFICATION OF: } \\
\hline \begin{tabular}{l|l|l|} 
a. REPORT & b. ABSTRACT & c. THIS PAGE \\
Unclassified & Unclassified & Unclassified \\
& & \\
\end{tabular} \\
\hline
\end{tabular}

\begin{tabular}{|l|l|} 
17. LIMITATION & 18. \\
OF ABSTRACT & OF PAGES \\
UL &
\end{tabular}

19a. NAME OF RESPONSIBLE PERSON

19b. TELEPHONE NUMBER (Include area code) 